RUY FERNANDO ZOCH RODRIGUES

\title{
ANTECIPAÇÃO DE TUTELA SEM O REQUISITO DA URGÊNCIA EM AÇÕES REPETITIVAS
}

\author{
TESE DE DOUTORAdo \\ ORIENTADOR: Prof. DR. FLÁVIO LUIZ YARSHELL
}

FACULDADE DE DIREITO DA USP

SÃO PAULO

2009 


\section{RUY FERNANDO ZOCH RODRIGUES}

\section{ANTECIPAÇÃO DE TUTELA SEM O REQUISITO DA URGÊNCIA EM AÇÕES REPETITIVAS}

Tese de Doutorado apresentada à Banca Examinadora da Faculdade de Direito da Universidade de São Paulo, como exigência parcial para a obtenção do título de Doutor em Direito, sob orientação do Prof. Dr. Flávio Luiz Yarshell

FACULDADE DE DIREITO DA USP

SÃO PAULO

2009 
Banca Examinadora 
Dedico este trabalho à Maria Lucia, minha mulher, ao meu filho Francisco e ao meu pai José Romeu 


\section{Agradecimentos}

Ao Professor Galeno Lacerda, pelo estímulo.

Ao Professor Flávio Luiz Yarshell, pela precisa orientação e pela postura compreensiva. A minha colega de escritório, Carolina Soares de Luca, pelo inestimável apoio logístico. 


\section{RESUMO}

O art. 285-A do Código de Processo Civil, inserido pela Lei 11.277, de 7 de fevereiro de 2006, incorporou ao sistema jurídico brasileiro a sentença de improcedência prima facie para a rápida solução de demandas, cuja inviabilidade é apurada liminarmente, porque repetem situação litigiosa já examinada em demandas anteriores julgadas improcedentes no mesmo juízo. Esta tese de doutorado parte do fenômeno inverso: as ações repetitivas em que a procedência se verifica à primeira vista (ou no curso da marcha do procedimento), também por causa de exames anteriores de situações conflituosas similares pelo mesmo juízo. Na impossibilidade de uma sentença de procedência prima facie, o estudo se propõe a verificar se é possível a antecipação de efeitos práticos do pedido formulado pelo autor, total ou parcialmente, sem outro requisito além da evidência do direito, oriunda das repetições. O fio condutor é o princípio da tempestividade da prestação jurisdicional (art. $5^{\circ}$, LXXVIII, da Constituição Federal); o ponto de partida, a distinção entre "jurisdição de massa" e "jurisdição convencional", assim como o exame do modo de ser do congestionamento do Judiciário pelo acúmulo gerado pelas ações repetitivas. O tema conduziu o estudo pelo interior do direito coletivo, sobretudo para a análise dos direitos individuais homogêneos, que representam uma das grandes fontes de repetições, quando veiculados em demandas singulares. Foi indispensável, ainda, examinar o tema do convencimento judicial necessário para o julgamento das repetições, o que remeteu ao estudo da prova, em especial os fatos notórios e as máximas da experiência. Por fim, o ponto de chegada foi o $\S 6^{\circ}$ do art. 273 do CPC, interpretado de forma a estender a expressão direito incontroverso expressa nesse dispositivo, para nela incluir a idéia de direito evidente.

Palavras-chave: ações repetitivas; antecipação da tutela sem urgência; direito evidente 


\section{ABSTRACT}

Art. 285-A of the Code of Civil Procedure, enacted by Law 11.277 of the 7th of February 2006, incorporated the prima facie order to dismiss into the Brazilian juridical system for the rapid resolution of lawsuits, whose inviability is established in a preliminary injuction, as the same legal issue is examined in previously adjudicated lawsuits denied in the same court. This thesis is based on the opposite phenomenon: repetitive lawsuits, of which its foundations are easily seen at first sight (or during the course of it), also because of previous studies of similar conflicting situations by the same court. Regarding the impossibility of a prima facie order to proceed, the study proposes to verify whether it is possible to totally or partially foresee the actual effects of the motion brought by the plaintiff without any other requirement besides the evidence of law, originating from the repititive lawsuits. The line of thinking is the principle of promptness of jurisdictional function (art. 5, LXXVIII, of the Federal Consitution); the starting point, the distinction between "mass jurisdiction" and "conventional jurisdiction", as well as the examination of the status of overloading of the Judiciary due to waiting lists filled with repetitive actions. The subject lead the study through the inner workings of community law, especially towards the analysis of homogeneous individual rights, which represent one of the great sources of repetitive actions, when brought in single lawsuits. Furthermore, it was essential to examine the subject of judicial persuasion necessary for the trying of repetitive actions, which brought up the study of evidence, especially well-known facts and maxims of experience. To conclude, the final issue regarded $\S 6$ of art. 273 of the Code of Civil Procedure, interpreted as a way of broadening the expression, undisputed law, conveyed in its provisions, so as to include in it the idea of indisputable rights.

Key words: repetitive actions; non-urgent anticipatory guardianship; indisputable rights 


\section{RIASSUNTO}

L'art. 285-A del Codice di Procedura Civile, inserito dalla Legge 11.277, del 7 febbraio 2006, ha introdotto nel sistema giuridico brasiliano la sentenza di inammissibilità prima facie per la rapida soluzione di azioni legali, la cui mancanza di presupposti è accertata preliminarmente, viso il ripetersi di situazioni litigiose già esaminate in azioni legali anteriori giudicate inaccettabili dallo stesso tribunale. Questa tesi di dottorato parte dal fenomeno inverso: le azioni ripetitive nelle quali l'ammissibilità si verifica a prima vista (o nel corso dell'andamento del processo), anche a causa di analisi anteriori di situazioni conflittuali simili effettuate dallo stesso tribunale. Nell'impossibilità di una sentenza di ammissibilità prima facie, lo studio si propone di verificare se è possibile anticipare effetti pratici di richieste formulate dall'attore, in modo totale o parziale, senza null'altro requisito oltre all'evidenza del diritto, procedente dalle ripetizioni.Il filo conduttore è il principio della tempestività del servizio giudiziario (art. 5, LXXVIII, della Costituzione Federale); il punto di partenza, la distinzione tra "giurisdizione di massa" e "giurisdizione convenzionale", ed anche l'esame della situazione del sistema giudiziario oberato dall'accumulo di lavoro generato da azioni ripetitive. L'argomento è stato sviluppato mediante studio interno del diritto collettivo, soprattutto per l'analisi dei diritti individuali omogenei che costituiscono una delle grandi fonti di ripetizioni, quando presentati in azioni legali individuali. Ł̀ stato indispensabile, oltretutto, esaminare il tema del convincimento giudiziario necessario per giudicare le ripetizioni, il che ha portato allo studio della prova, in modo speciale dei fatti notori e delle massime dell'esperienza. Infine, il punto d'arrivo è stato il $\S 6^{\circ}$ dell'articolo 273 del CPC, interpretato in modo da allargare l'espressione "diritto incontroverso", presente in questa disposizione, per includervi l'idea del diritto evidente.

Parole chiave: azioni legali ripetitive; anticipazione della tutela senza urgenza; diritto evidente 


\section{SUMÁRIO}

INTRODUÇÃO 10

\section{PRIMEIRA PARTE - CONSIDERAÇÕES GERAIS SOBRE A JURISDIÇÃO E O PROCESSO.}

1. O cenário da jurisdição

1.1. Ações de massa e ações decorrentes da produção em massa de bens e serviços

1.2. O congestionamento do Judiciário 24

1.3. A burocratização da justiça: "jurisdição convencional" e "jurisdição massificada"

2. O cenário do processo ......................................................................................... 33

2.1. Variações da realidade e a crise do processo ordinário ............................... 34

2.2. Técnicas de aceleração no processo civil .................................................. 39

2.2.1. Introdução: sumarização formal e substancial .................................. 41

2.2.2. A técnica do julgamento antecipado ............................................... 42

2.2.3. A técnica do procedimento monitório............................................. 43

2.2.4. A técnica da antecipação da tutela ................................................. 45

2.2.5. Decisões provisionais de pacificação, relativamente independentes do direito das partes (mérito) em litígio .................... 49

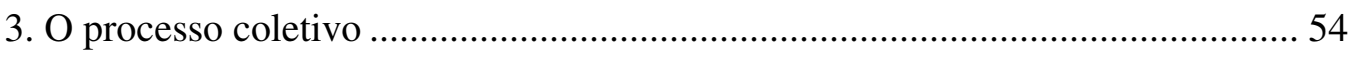

3.1. As três categorias dos direitos coletivos.................................................. 57

3.2. Direitos Individuais homogêneos em juízo: ações coletivas e ações individuais

3.3. Fragilidades do sistema de tutela coletiva de direitos individuais

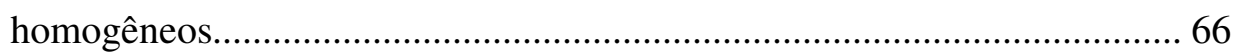

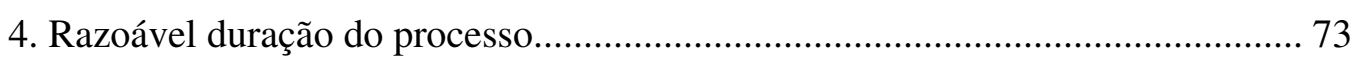

4.1. Demoras necessárias e demoras desnecessárias dos processos ................... 74

4.2. Fatores exógenos e endógenos de demora................................................ 77

4.3. A morosidade como tema de processo ....................................................... 78

4.4. Devido processo legal e tempestividade da jurisdição ................................. 81

4.5. A tempestividade da jurisdição no contexto da eficácia das normas

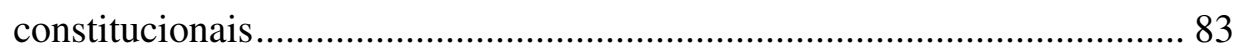

4.6. Conflito entre segurança jurídica e tempestividade: o problema da harmonização de princípios constitucionais. 


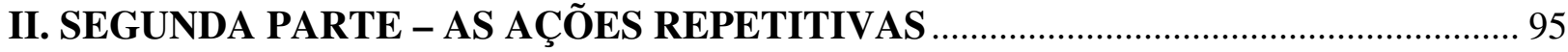

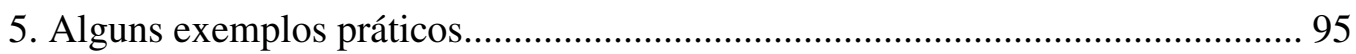

6. Antecipação da tutela em ações repetitivas sem o requisito da urgência: possibilidade e temas de interesse em torno da proposta..................................... 99

7. A repetitividade e a cultura de massa ................................................................103

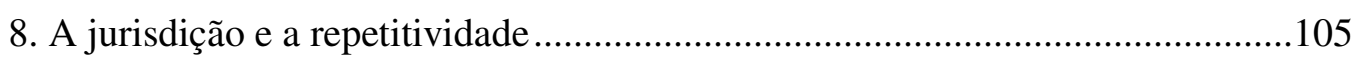

8.1. A repetitividade em técnicas processuais .................................................108

8.2. A repetitividade no processo: tendência e limites ......................................110

9. A repetitividade e a improcedência prima facie: art. 285-A do CPC..................111

9.1. O sentido da locução “casos idênticos”.....................................................112

9.2. Os fatos e o direito no âmbito do art. 285-A do CPC..................................114

9.3. O tratamento das situações excepcionais na incidência do art. 285-A

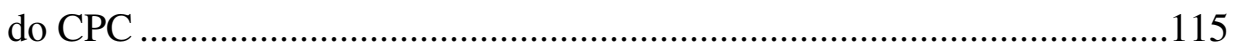

9.4. A jurisprudência do juízo como requisito no art. 285-A do CPC ...............116

10. A repetitividade e a procedência constatada prima facie ..................................118

10.1. O tema da prova na antecipação da tutela em ações repetitivas ................119

10.2. Fatos notórios e máximas da experiência .................................................124

11. A inserção da proposta na legislação processual ..........................................136

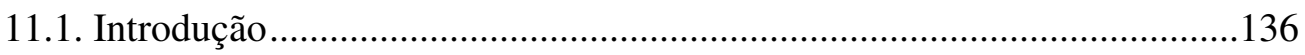

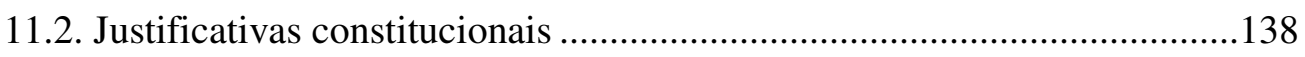

11.3. O posicionamento da proposta no art. $273, \S 6^{\circ}$, do do CPC ....................140

11.3.1. Momentos próprios para a antecipação da tutela.........................147

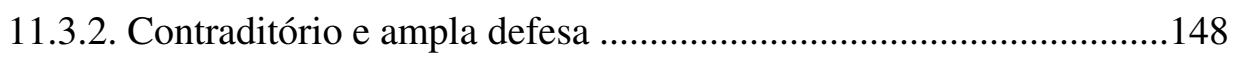

11.3.3. Efetivação da tutela antecipada ......................................................149

11.3.4. Antecipação de efeitos de pedido único (inexistência de cumulação) e de parte de pedido..........................................................153

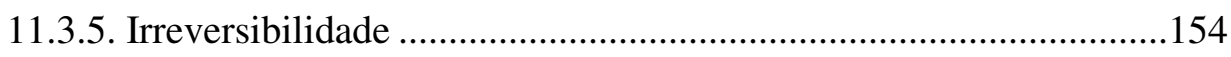

11.3.6. A tutela de urgência em demandas repetitivas ...............................155

12. A tutela da evidência na obra de Luiz Fux - exame comparativo .................156

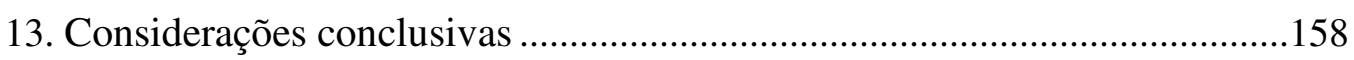

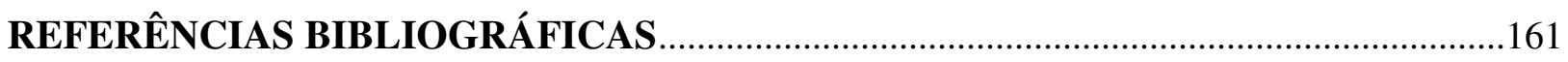




\section{INTRODUÇÃO}

Este estudo parte da constatação prática de que certas demandas permitem antever, desde o primeiro momento, que a sentença final será de procedência. Não raro, pode-se até mesmo prever o teor da resposta que virá da parte sequer ainda citada. Há exemplos mais antigos e bem recentes: as ações para o desbloqueio de valores congelados no Governo Fernando Collor, ainda na década de 90 do século passado, ou a recente enxurrada de demandas de investidores em contas de poupança para buscar, junto às instituições financeiras, as diferenças de correção monetária do chamado Plano Bresser. Fora do ambiente bancário, a mesma realidade se repete no setor da saúde privada, por exemplo, em ações as mais diversas, como as que tratam de limites de tempo de internação hospitalar, ou cobertura de custos para determinadas patologias. E há, ainda, os conflitos de consumo em setores que operam em regime de alta concentração econômica, como o da telefonia móvel, da distribuição de energia, alguns tipos de seguros, etc.

O litígio se estabelece com efetiva controvérsia nos primeiros casos. Depois, nos seguintes, o que se dá é a repetição incessante das mesmas iniciais, contestações, e conseqüentemente, das mesmas sentenças.

As repetições produzem, em geral, enorme convicção prévia sobre os fatos e sobre o direito. Ou seja, o direito acaba surgindo evidente a priori, e o ritual do processo que se segue à propositura da demanda não altera a certeza formada no início. Trata-se de realidade que guarda simetria com a hipótese do art. 285-A do CPC, norma que autoriza o juiz a prolatar sentença de improcedência prima facie, se convencido liminarmente que a nova demanda que lhe chega às mãos é inviável. Um convencimento da mesma natureza daquele descrito acima, apenas orientado em direção inversa.

Pareceu-nos que também a superevidência do direito do autor, constatável em demandas repetitivas, deveria merecer vantagem proporcional. Não só pela efetividade encarada do ponto de vista do demandante individual, mas sobretudo pelo quanto uma resposta com esse nível de rapidez, partindo do Judiciário, pode significar ao réus de ações repetitivas (geralmente grandes corporações) na avaliação do custo-benefício de estarem em juízo em demandas dessa natureza. E, nessa linha, pelo o quanto pode significar na redução da litigiosidade de massa. 
Mas o Código de Processo Civil não contempla expressamente, em caráter genérico, a antecipação imediata de efeitos práticos do direito evidente, a menos que venha acompanhado do periculum in mora. Por isso, o trabalho que desenvolvemos, partindo de alterações do CPC e da Constituição Federal, bem como do contexto peculiar das ações repetitivas, foi no sentido da releitura do art. 273 daquele Código, em especial do seu $\S 6^{\circ}$, procurando equiparar o direito incontroverso mencionado na norma ao direito evidente, revelando assim a viabilidade da antecipatória sem o requisito da urgência, para o fim acima mencionado, suscetível de produzir efeitos práticos imediatos, e podendo, inclusive, ser deferida inaudita altera parte.

A exegese convencional vincula o art. $273, \S 6^{\circ}$, do CPC ao fenômeno do julgamento antecipado da lide, o que impõe severas restrições à sua operacionalidade. Afirma-se que a tutela nele compreendida só é viável após a fase de contestação (vedada, pois, a antecipatória liminar), e que os atos de cumprimento devem equivaler ao da execução provisória de uma sentença dinâmica de cumprimento geralmente incapaz de alcançar a realização de efeitos práticos em curto espaço de tempo, como se dá na efetivação das antecipatórias urgentes.

Desde cedo a doutrina vem procurando ajustar essa exegese demasiado limitada. Mesmo assim, a tarefa da releitura levada a efeito neste estudo exigiu ampla contextualização dentro e fora do CPC.

Em primeiro lugar, procurou-se definir a necessidade prática do instituto, estabelecendo um corte metodológico que distingue, no modo de ser da jurisdição contemporânea, o tratamento a ser empregado na condução das ações de massa e das ações convencionais. Depois, identificou-se o reflexo dessa diferenciação no interior do CPC, em dispositivos legais destinados ao manejo das repetitividades, percebendo-os como resultado de uma tendência do processo brasileiro, com perfis particulares, marcada pelo interesse de racionalização no tratamento de conjuntos.

Mas para evitar proposições simplistas, foi necessário posicionar histórica e politicamente a dinâmica que explica o Judiciário em sua configuração contemporânea, pressionado pela economia de massa e procurando responder à litigiosidade que ela produz, com as deficiências naturais de um processo civil concebido com base em configuração sócio-política e econômica muito diversa da atual. Estudou-se, ainda, a anatomia interna do processo civil, as suas técnicas de aceleração, tudo com o fim de traçar um quadro evolutivo que, em si mesmo - embora não somente -, revele a necessidade do 
tratamento diferenciado desse enorme contingente de litigiosidade, em termos quantitativos, que é o das ações repetitivas.

Logo ao depararmos o fenômeno da massificação e o difícil relacionamento da Justiça com os contextos de massa, o estudo exigiu o exame do chamado direito coletivo, cujo sentido, em nível processual, é procurar soluções "moleculares", evitando a atomização de litígios individuais que possam ser resolvidos em uma só ação coletiva.

Grande parte das demandas repetitivas - talvez a maior parte - é composta de direitos individuais homogêneos fracionados em centenas ou milhares de postulações individuais. Assim, não faria sentido imaginar um instituto que se justifica nas repetições, se as demandas coletivas pudessem concentrá-las, evitando que se repetissem. Mas o resultado do exame comprovou que não há como obviar soluções abrangentes na via da jurisdição coletiva por variados motivos, alguns de natureza passageira, dependentes de iniciativas do legislador, outros de caráter permanente, próprios da estrutura de certos direitos, ou de contingências culturais.

Não obstante, essas investigações evidenciaram que a maior parte das demandas repetitivas é, em essência, direito coletivo veiculado individualmente, o que agregou relevância política e social à idéia da antecipação da tutela naquele segmento litigioso.

As aproximações entre a hipótese do art. 285-A do CPC e a antecipação da tutela aqui proposta foram definidas em capítulo próprio, no qual foi detalhado o sentido da repetitividade, seja o da Lei, seja o do fenômeno social, que é de onde o direito se alimenta em última análise. E nessa ampla acepção verificou-se o renovado vigor dos fatos notórios e das máximas da experiência, cuja funcionalidade se amplia na dinâmica das repetições. Trata-se de aporte de grande utilidade para transpor a zona problemática de distanciamento entre o art. 285-A e as antecipatórias (entre procedência e improcedência), qual seja a da prova e a do regime de convencimento suficiente para autorizar a decisão judicial.

Revelada, assim, a necessidade prática e a racionalidade da proposta, passou-se à fundamentação constitucional. Primeiro na perspectiva particular da razoável duração do processo (art. $5^{\circ}$, LXXVIII da CF); depois na visão mais geral da efetividade da jurisdição e do devido processo.

Foi após esse percurso que iniciamos, então, a exegese do $\S 6^{\circ}$ do art. 273 do CPC. De saída, destacamos um elemento central da interpretação: o dispositivo era o nosso ponto de chegada e não o de partida, perspectiva que autoriza orientar a releitura da norma pelas 
necessidades e condicionamentos que nos levaram até ela, e que conduz a soluções mais amplas do que a exegese que se limite à sua compreensão dogmática no interior do sistema do Código.

Além de assimilar a idéia de direito evidente ao contexto do direito incontroverso expresso no $\S 6^{\circ}$, definimos a possibilidade de decisão a qualquer momento, inclusive liminar, e o regime de efetivação da tutela antecipatória proposta nos mesmos termos do empregado nas tutelas urgentes. 


\section{PRIMEIRA PARTE - CONSIDERAÇÕES GERAIS SOBRE A JURISDIÇÃO E O PROCESSO}

\section{O cenário da jurisdição}

Estudar jurisdição é também estudar o Estado, pois o tema é jurídico e é político a um só tempo. E para estudar a jurisdição no interior do Estado contemporâneo, mesmo em uma análise sumária, é indispensável remeter ao universo de suas raízes, fixadas no período do chamado Iluminismo. Lá se forjaram os valores liberais, que em linha evolutiva ecoam nas constituições atuais em diversos setores, inclusive na eleição dos direitos individuais. Lá se assentaram, também, os princípios da Revolução Industrial, que em sua irresistível evolução produziu um dos traços decisivos das sociedades ocidentais, a massificação, fenômeno cujo significado vai além do puramente econômico, constituindo elemento indissociável da cultura do nosso tempo.

Em nível político, o Estado liberal, que emergiu do Iluminismo e que tem como marco histórico a Revolução Francesa, organiza-se sob a premissa da soberania popular, concretamente operacionalizada pelo caminho da democracia representativa. Os valores fundantes são a igualdade, a propriedade e a liberdade. O legislativo tem a primazia no corpo do Estado, porque a lei que produz é tida como a expressão da vontade do povo, por isso mesmo dotada de alto grau de legitimidade ${ }^{1}$.

Nos limites de um tal arranjo, o papel do juiz é algo subalterno: guardião da lei tal como um funcionário, ocupado com a sua aplicação prática no arbitramento dos conflitos entre particulares. O “justo" não compõe a sua pauta senão remotamente, porque a justiça do ordenamento jurídico está no fato de que ele constitui expressão da vontade soberana do povo, que escolhe seu próprio destino ${ }^{2}$.

\footnotetext{
${ }^{1}$ Conforme José Rogério Cruz e Tucci: “Com o notório fortalecimento da idéia de separação dos poderes, colocada à prova após as revoluções dos Estados Unidos da América (1776) e da França (1789), a vontade popular passa a ser considerada a única investida de legitimidade (...). CRUZ E TUCCI, José Rogério. Precedente judicial como fonte do direito. São Paulo: Ed. Revista dos Tribunais, 2004. p. 197.

${ }^{2}$ Mesmo no fluir da história, quando o povo é substituído pelo imperador, como ocorreu na França, o esquema da função jurisdicional, com a codificação, no auge do positivismo jurídico, continuou o mesmo, sendo relegado ao juiz o papel de "bouche de la loi”. Conforme CRUZ E TUCCI, José Rogério. Precedente judicial como fonte do direito, cit., p. 199.
} 
Há sensíveis diferenças no desenvolvimento dos países centrais (o chamado Primeiro Mundo) e dos periféricos. E também há diversidades na linha evolutiva dos sistemas da civil law e da common law. Tudo isso influencia no papel que a jurisdição vai assumindo ao longo da história. Mas guardadas as diversidades, a organização do tema em uma cronologia generalizante tem valor metodológico que vale a pena utilizar.

O edifício teórico liberal subverte-se na prática capitalista, manifestando toda sua face opressora, em princípio, no campo das relações de trabalho, em que a igualdade formal entre patrões e empregados, desequilibrados pela disparidade de forças, conduz a um contexto contratual de exploração que afeta a essência do sistema. Essa face deformada evolui para outras relações contratuais, atraindo para a cena legislativa a necessidade de que a lei corrija os desequilíbrios entre os agentes nas relações privadas. Tal conjuntura de correção conduz o ato legislativo à contingência da igualdade substancial e da justiça nas relações contratuais. E nessa linha, em que a lei se abre ao valor "justiça", problematiza-se o esquema teórico de sua aplicação, pois a medida do justo não escapa da discricionariedade do julgador. E então o juiz já não pode atuar como instrumento neutro do ordenamento jurídico.

Um segundo momento da evolução histórica corresponde ao período que se convencionou denominar Estado do Bem-Estar Social, fruto da expansão da idéia de igualdade substancial para além do círculo reduzido dos contratos. Imputa-se ao Estado, então, o dever de propiciar a equalização das desigualdades entre os indivíduos no universo de setores tidos por essenciais ao desenvolvimento humano. Assim os da saúde, do emprego, da educação e da moradia; depois as atividades promocionais no setor da arte e da cultura, bem como o controle das atividades financeiras, a contenção de práticas econômicas monopolistas, o fomento de atividades produtivas economicamente inviáveis na área da pesquisa científica da produção primária, etc ${ }^{3}$.

\footnotetext{
${ }^{3}$ Não é possível definir um momento a partir do qual se teria instalado o Estado social, ou Estado do BemEstar Social (comumente denominado entre nós, também, pela expressão inglesa welfare state). Como produto de um desenvolvimento histórico, suas raízes estendem-se em momentos diversos, mas a sua consolidação efetiva acontece no século XX, permanecendo vivo nos tempos atuais, muito embora a tentativa de retomada do liberalismo, em especial na economia, pelo chamado neoliberalismo. Mauro Cappelletti, para definir sua gênese e contornos, valendo-se da lição de Koopmanns, salienta: "o tipo de estado que, com expressão aproximativa, chamamos welfare state, foi principalmente o resultado da atividade legislativa. Os primeiros passos foram tomados na área da política social, mediante legislação pertinente ao direito do trabalho, da saúde e da segurança social; mas gradualmente as intervenções se estenderam à esfera da economia, mediante leis de caráter antimonopolístico, sobre a concorrência, transportes e agricultura; e, finalmente, chegamos à presente situação, com a extensão do setor público, o exercício de generalizado controle do estado sobre a economia, a assunção de responsabilidade do estado em questões de emprego, a elaboração de planos de assistência social e o financiamento de atividades sem
} 
Essa ampla atividade se processa mediante mais e mais regulação jurídica, com o aumento notável da produção de normas. O legislativo, incapaz de acompanhar a demanda normativa na velocidade e volume exigidos, ou delega ao Executivo a normatização, ou opta pela produção de leis mais “abertas”, adaptáveis à variação acelerada dos fatos pela atividade interpretativa dos aplicadores. O Executivo assume então o centro de gravidade do Estado, antes ocupado pelo Legislativo, e experimenta um crescimento exacerbado. Agiganta-se, no dizer de Mauro Cappeletti ${ }^{4}$, transformado em uma enorme burocracia. E como é da natureza da organização burocrática, volta-se para si mesmo, cada vez mais distante do diálogo com os cidadãos.

A relação com esse poder distante e autocentrado torna-se problemática, e o Judiciário assume progressivamente a condição de arena do embate da sociedade civil com o Estado, cujo ponto culminante já não é a garantia dos direitos civis contra um EstadoLeviatã que, ao se movimentar, ameaça a liberdade do indivíduo, mas a garantia da concretização das promessas do welfare state, mediante a implantação efetiva dos programas de promoção de bem-estar positivados em normas.

A par disso, a atribuição que o desenvolvimento do constitucionalismo cometeu ao judiciário, de guardião da constituição, acresceu à atividade jurisdicional aquela de censor do próprio legislativo no controle da constitucionalidade das leis, seja difuso ou concentrado.

A imagem do juiz como árbitro de querelas privadas, neutro e ausente da cena política, transforma-se na linha evolutiva do tempo. Contudo esse resultado não veio de uma luta que os próprios juízes tivessem travado para ampliar seu espaço. Foi o crescimento do Legislativo e do Executivo, acima descritos, que no dizer de Mauro Cappelletti produziram, quase que como efeito colateral inevitável, o correspondente crescimento da jurisdição. Não um crescimento quantitativo, apenas. Não; foi a própria essência da atividade jurisdicional que se modificou.

O juiz liberal, cuja atividade era dizer o direito para redimir conflitos individuais particulares (um direito que se entendia completo, claro, sedimentado por uma lenta evolução histórica que, em certo momento, a sociedade capturava e elevava à condição de lei na pessoa de seus representantes eleitos), esse juiz já não tem como exercer as tarefas

fins lucrativos, como, por exemplo, no campo das artes, obras públicas, e renovação dos centros urbanos em decadência. CAPPELLETTI, Mauro. Juízes legisladores? Porto Alegre: Sérgio Antônio Fabris, 1993. p. 35.

${ }^{4}$ CAPPELLETTI, Mauro. Juízes legisladores?, cit., p. 46. 
que o novo quadro político-jurídico criado lhe imputa. A questão da justiça na aplicação da lei, e a própria aplicação de uma lei que se concebe diferente, "aberta" e exigindo atividade integrativa, com a qual o juiz completa o ato político-legislativo ao torná-lo concreto, atraem para a jurisdição funções que eram antes reservadas ao legislador. Por outro lado, a concreção de valores colocados em normas prospectivas (os programas sociais), ou mesmo de princípios constitucionais altamente genéricos, não só exige do juiz um raciocínio diferente (projetado ao futuro e não à estabilização de conflitos pretéritos, como na postura clássica do dizer o direito para resolver conflitos já acontecidos ${ }^{5}$ ), mas eventualmente lhe impõem atuação gerencial própria da Administração, do que é exemplo a chamada reforma estrutural do direito norte-americano ${ }^{67}$.

Por fim, o controle da constitucionalidade, tanto dos atos do legislador como dos atos administrativos, completam a imagem do juiz contemporâneo, como ator da chamada “judicialização da política”, que em síntese muito apertada - e por isso mesmo parcial pode ser definida como a participação do juiz na elaboração do direito e na condução do Estado.

Assim como as constituições e o direito progrediram, garantindo princípios de natureza liberal (individuais, como a liberdade, a igualdade e a propriedade) e acrescentando outros valores de natureza social, também a jurisdição manteve entre suas atribuições aquela de resolver o mais simples dos conflitos individuais, de natureza privada e disponível, mediante a só declaração do direito, acrescentando atribuições de natureza avançada do ponto de vista técnico e político. E tudo isso constitui a jurisdição contemporânea, em que o juiz, ao julgar a clássica "pretensão resistida", encarará o caso não só em sua individualidade, mas também em sua significação social. E, por outro lado,

\footnotetext{
${ }^{5}$ Carlos Alberto de Salles indica o "modelo tradicional de litigância, voltada para eventos findos $e$ passados" que se traduz em uma jurisdição "atuando de maneira retrospectiva" sempre voltada à "solução compensatória". SALLES, Carlos Alberto de. Execução específica e ação civil pública. In: MILARÉ, Édis (Coord.). A ação civil pública após 20 anos: efetividade e desafios. São Paulo: Ed. Revista dos Tribunais, 2005. p. 90.

${ }^{6}$ Segundo Owen Fiss, a reforma estrutural aconteceu a partir da constatação feita pelos juízes de que a aplicação da Constituição não era viável apenas decidindo querelas; exigia um posicionamento proativo. Assim, por exemplo, nos problemas de tratamento igualitário de minorias negras em escolas, hospitais, manicômios, etc, para garantir a concretização dos princípios igualitários, os juízes ingressaram nessas instituições nomeando special masters para atuar dentro delas, garantindo o objetivo planejado pela jurisdição. (FISS, Owen. Um novo processo civil: estudos norte-americanos sobre jurisdição. São Paulo: Ed. Revista dos Tribunais, 2004. p. 26).

${ }^{7}$ Carlos Alberto de Salles constata esse tipo de atuação, no Brasil, no âmbito de execuções de certas decisões relativas aos direitos coletivos e difusos que precisam de tempo para ser implementadas, eventualmente impondo ao juiz a necessidade de "outorga de responsabilidades para órgãos auxiliares, de características anteriormente pouco conhecidas em nosso sistema, e de supervisão e acompanhamento prolongado das atividades executivas". SALLES, Carlos Alberto de. Execução específica e ação civil pública, cit., p. 89.
} 
ao aplicar os princípios constitucionais ou as sofisticadas normas prospectivas, não deixará de atentar para a circunstância de que sua atividade é regida, em linha de princípio, pela vontade de um ordenamento jurídico prévio que lhe deve orientar e limitar a conduta.

\subsection{Ações de massa e ações decorrentes da produção em massa de bens e serviços}

A vida gregária, como é da natureza humana, exige o estabelecimento de padrões de conduta, cuja observância é requisito para a manutenção do grupo como tal. Começa aí um processo de padronização que avança quanto maior for a dimensão do grupo, e que se incorpora ao longo das gerações como cultura. A grande maioria repete ações até inconscientemente, reproduzindo um padrão social. E assim a convivência é viabilizada.

A Revolução Industrial potencializou enormemente essa tendência à padronização ao desenvolver tecnologias que proporcionaram a produção repetitiva de bens. Foi um momento histórico em que várias circunstâncias de natureza política, científica, religiosa, etc, confluíram em processos ainda hoje em expansão, como é o da urbanização, por exemplo, e o do capitalismo ${ }^{8}$.

A interação desses fenômenos agindo uns sobre os outros permanentemente (industrialização, produção em série, urbanização, novas tecnologias, capitalismo, etc), produz a realidade presente ${ }^{9}$, em que se podem identificar, para os fins deste estudo, dois aspectos da massificação, quais sejam a emergência de direitos sem titulação específica em indivíduos identificados, pertencentes a grupos ou mesmo à população humana em seu todo (ou seja, direitos pertencentes a massas de pessoas), e a emergência de direitos

\footnotetext{
${ }^{8}$ Sobre o significado da "revolução industrial" para o mundo de hoje, novamente a síntese de Mauro Cappelletti: "Os fenômenos do nascimento do welfare state e do crescimento e do crescimento dos ramos legislativo e administrativo foram por si mesmos, obviamente, o resultado de um acontecimento histórico de importância ainda mais fundamenta: a revolução industrial com todas as suas amplas e profundas conseqüências econômicas, sociais e culturais. Essa grandiosa revolução assumiu a característica que se pode sintetizar numa palavra certamente pouco elegante, mas assaz expressiva: 'massificação'. Todas as sociedades avançadas do nosso mundo contemporâneo são, de fato, caracterizadas por uma organização econômica cuja produção, distribuição e consumo apresentam proporções de massa. Trata-se de característica que, por outro lado, ultrapassa o simples setor econômico, para se referir também às relações, comportamentos, sentimentos e conflitos sociais. CAPPELLETTI, Mauro. Juízes legisladores?, cit., p. 57.

${ }^{9}$ Sobre a complexa composição de fatores que caracteriza a sociedade pós-industrial, vide BENJAMIN, Antônio Herman V. A insurreição da aldeia global contra o processo civil clássico: apontamentos sobre a opressão e a libertação judiciais do meio ambiente e do consumidor, In: MILARÉ, Édis (Coord.). A ação civil pública: lei 7.347/85: reminiscências e reflexões após dez anos de aplicação. São Paulo: Ed. Revista dos Tribunais, 1995. p. 72-73.
} 
individuais vinculados às relações jurídicas que se formam na cadeia da produção e consumo em massa de bens e serviços. Percebe-se, desde já que, em linhas gerais, os primeiros correspondem aos chamados direitos coletivos e difusos, e os demais, aos direitos individuais homogêneos, cujo exame mais detalhado é objeto de tópico específico.

Essa segunda categoria é a que mais interessa no âmbito deste trabalho, pois no interior dela ocorrem as repetições que, em juízo, produzirão a grande maioria das ações repetitivas ${ }^{10}$.

Mas a produção e consumo repetitivos não formam, ainda, o cenário integral. É necessário agregar uma outra variável, que é a economia de escala. Nesta, o ganho do empreendedor se constrói no conjunto de operações. Para a empresa que explora serviços de telefonia, por exemplo, uma só operação econômica, como o telefonema praticado por um consumidor, em sua individualidade, é irrelevante em termos de ganho. Só o conjunto de operações, tanto mais atraente quanto mais amplo, é que estabelece a lógica da atratividade da exploração daquele segmento de produto ou serviço.

Escala exige padrões, tanto melhores quanto mais simplificados, para propiciar a repetição em nível de automatização. Assim, o modelo pode se reproduzir sozinho, atendendo à demanda massiva e, ao fazê-lo, maximizando lucros. Por trás disso, claro, há uma teia de outras variáveis, de natureza científica, inclusive, próprias da engenharia, da administração, da logística, da comunicação de massa, etc.

Há um lado preocupante do fenômeno, quando projetado em perspectiva gigantesca, como a globalização vem sugerindo para determinados setores. Mas, como em tudo, há também um outro lado: certos bens não são viáveis de serem produzidos, em termos de custo, senão em esquemas de escala. Assim, por exemplo, a telefonia, já mencionada. Outros tipos de bens até podem ser viáveis, mas, pelo custo, ficarão restritos a uma pequena parcela da população. Os automóveis são o exemplo talvez mais contundente, até porque remetem a um ponto central da massificação, o denominado Fordismo $^{11}$. Produzia-se artesanalmente o automóvel para poucos consumidores, até que o

\footnotetext{
${ }^{10}$ Vale alertar, que existem demandas repetitivas que não correspondem à estrutura dos direitos individuais homogêneos. A definição de ação repetitiva no n. 6, infra, esclarece o ponto, sem invalidar, no entanto, a informação de que o centro mais importante de produção de demandas repetitivas corresponde aos litígios ocorrentes envolvendo direitos individuais homogêneos.

${ }^{11}$ Segundo Paulo Sandroni: "Conjunto de métodos de racionalização da produção elaborados pelo industrial norte-americano Henry Ford, baseado no princípio de que uma empresa deve dedicar-se a produzir um tipo de produto (...). Para reduzir custos, a produção teria de ser em massa (...)”. (SANDRONI, Paulo. Dicionário de economia do século XXI. Rio de Janeiro: Record, 2005. p. 353).
} 
modelo massificado de produção, baixando custos, generalizou a possibilidade de acesso ao automóvel, em uma espécie de democratização de raiz econômica.

Certas atividades dependem, mais que outras, como visto, da lógica da escala. E algumas delas, tidas por essenciais à vida moderna, foram objeto da intervenção do Estado, mediante a monopolização ou o dirigismo com maior ou menor intensidade. Assim a produção e distribuição de energia elétrica, a propriedade da água, as telecomunicações, alguns tipos de mineração, a atividade bancária, a assistência à saúde, a previdência, etc.

No período do Estado do Bem-Estar, eram atividades desenvolvidas pelo Estado, donde o crescimento do poder executivo referido no início. Mas a ineficiência da exploração pelo Estado vinha entravando o desenvolvimento desses setores, de resto ambicionados pelo capital privado, que exerceu e exerce pressão contínua e progressiva pela privatização ${ }^{12}$. E foi o que efetivamente ocorreu de maneira disseminada a partir de certos eventos mundiais, como a crise do petróleo da década de 70 e a desagregação do bloco socialista, simbolizada pela queda do muro de Berlim, com o conseqüente abalo da idéia de estatização da atividade produtiva e de possibilidade de vida econômica fora do capitalismo. Trata-se de temas de alta profundidade, que se abrem para um conjunto de reflexões indefinido. A crise do capitalismo e da cultura de massa, na sua conjuntura contemporânea, certamente atingiu um ápice desagregador que exige revisões. Mas nos limites deste trabalho, não faz sentido enveredar por esses outros caminhos, porque a intenção, aqui, é apenas descritiva.

A industrialização e a urbanização do Brasil, como causa de massificações, que redundam em conflitos com conseqüências diretas no aumento de volume de demandas no Judiciário, são fenômenos relativamente próximos, iniciados faz sessenta anos, mais ou menos. Mas foi o processo de privatizações que teve início no Governo Fernando Henrique Cardoso, transferindo ao capital privado alguns daqueles setores que só se justificam em esquema de economia de escala, e cuja exploração tem grande impacto social, que realmente intensificou o congestionamento da Justiça. Para uma amostragem do fenômeno, veja-se, na atividade da advocacia, o ritmo da estruturação de certos escritórios das grandes cidades. A partir da década de oitenta, a advocacia, até então eminentemente artesanal,

\footnotetext{
${ }^{12}$ Durante a elaboração deste estudo, após a redação desta parte inicial, sobreveio a crise econômica mundial de 2008, iniciada nos Estados Unidos. No esforço pela contenção dos efeitos avassaladores da crise, o Governo norte-americano estatizou enormes fatias de corporações financeiras. Consta que a providência é transitória, no entanto não é possível, ainda, tecer um prognóstico sobre os efeitos da crise e sobre se ela redundará em alteração efetiva da linha evolutiva do capitalismo e da globalização que se instalou em nível planetário.
} 
formada por conjuntos de profissionais liberais associados, passa a incorporar grandes estruturas profissionais, verdadeiros exércitos de funcionários envolvidos em atividades repetitivas na produção de serviço jurídico. O surgimento desse tipo de escritórios serve bem para ilustrar a conjuntura, pois são o meio caminho entre a massificação em grande escala de produção e consumo de bens e serviços e a massificação de demandas despejadas no Judiciário.

Em paralelo, o aquecimento da economia, a expansão do crédito para enormes contingentes de população antes praticamente à margem do consumo, e a globalização, empurrando a indústria como um todo para os processos de produção em escala, completam o cenário.

Não tardou para que o fenômeno aportasse no Judiciário, trazendo para a cena judicial suas características próprias. Foi um processo mais ou menos lento, marcado por episódios históricos específicos, como o bloqueio de valores do chamado Plano Collor, na década de noventa do século XX, em que os recursos de toda a população brasileira, acima de determinado valor, foram confiscados pelo período de um ano como técnica de controle inflacionário, produzindo enorme impacto de massa no Judiciário e, como conseqüência, um imenso volume de demandas repetitivas. Mas, em caráter amplo e permanente, o início do ciclo das ações repetitivas imputa-se, provavelmente, às discussões sobre limites de juros em operações financeiras. Outro golpe importante foi a privatização da distribuição de energia elétrica e do setor de telefonia, este último marcado por um crescimento sem precedentes no âmbito da telefonia móvel. E por aí seguem diversos outros setores, como o do fornecimento de remédios à custa do Estado, ou as discussões judiciais sobre multas de trânsito, que se tornaram verdadeiros segmentos na advocacia, com a criação de escritórios especializados exclusivamente nessas discussões. Também as operações de seguro saúde chegaram a constituir, em determinada época, pólo gerador de conflitos repetitivos de grande escala. Os cartões de crédito, as operações de leasing, os empréstimos de pequenos valores com desconto em folha, mediante a triangulação de agentes financeiros com associações de servidores públicos, etc.

Boaventura de Souza Santos, à frente de um grupo multidisciplinar de juristas e sociólogos, desenvolveu minuciosa pesquisa sobre o Judiciário português, sintetizada na obra "Os Tribunais nas Sociedades Contemporâneas"13. Trata-se de um conjunto de

\footnotetext{
${ }^{13}$ SANTOS, Boaventura de Sousa et al. Os tribunais nas sociedades contemporâneas: o caso português. Porto: Afrontamento, 1996.
} 
informações cujas linhas gerais são aplicáveis a qualquer país do mundo capitalista, não só do ocidente. Embora situado entre os anos de 1989 a 1993, e, portanto, antes do impacto no Judiciário do notável aquecimento da economia portuguesa com o ingresso na Comunidade Européia, o estudo revela aspectos importantes da lógica capitalista e massificada na sua relação com a Justiça.

Para avaliar esse setor litigioso (foram estudados outros setores que não têm a ver com a atividade econômica), o estudo valeu-se de metodologia da escola norte-americana da análise econômica do direito, que procura matematizar o exame das causas pelas quais o agente econômico busca o Judiciário ou, uma vez levado a ele, mantém-se na demanda, causas fundamentalmente baseadas no cálculo de custo-benefício. Assim, por exemplo, uma demanda contra um banco para repetição de indébito é contestada até o último recurso, mesmo convencido o banco de que perderá a ação, porque o dinheiro devido, aplicado em suas operações financeiras, rende mais que o custo da mora praticado em juízo.

Confrontada com essa lógica matemática, e informada da morosidade média dos processos, a estrutura é levada a tomar a única decisão que a lógica econômica processa. $\mathrm{E}$ uma tal decisão lançada em um frenético esquema de concessão de crédito - e conseqüente inadimplemento - em escala, produz também escala para o prestador de serviço - o escritório de advocacia - e redunda em congestionamento judiciário. Trata-se, no entanto, de um congestionamento diferente, porque, em geral, com alguns traços distintivos acidentais, as demandas repetem a essência de uma idêntica operação de base, e, a certa altura, explicam-se na política adotada pela instituição financeira mais do que no direito que este ou aquela tenha relativamente ao caso.

O problema é que a massa de demandas desse tipo, que se explica em uma política geral de enfrentamento de litígios e não necessariamente no direito, e que, nessa linha, possui uma anatomia interna muito semelhante (senão idêntica) em todas as unidades do conjunto, é absorvida pelo Judiciário por um procedimento que é o mesmo aplicado para a cobrança de uma dívida entre dois particulares, por exemplo, salvo aqueles créditos que são veiculados em juizados especiais. E é nessa medida que se pode produzir aquele extremo destacado no início deste estudo: sabe-se, desde a autuação, o destino final da demanda.

Esta configuração do ganho direto que a instituição aufere, motivando-a à demanda e gerando massa de litígios, reflete a mais elementar das lógicas, embora as ações que dela 
decorram sejam altamente impactantes no Judiciário. Contudo, há outros cenários nos quais se demanda com motivações que não têm a ver diretamente com o direito.

O estudo português referido acima aponta uma outra peculiaridade entre demandas de massa, que é a exploração de todas as possibilidades de defesa pelo agente econômico, mesmo quando esteja convencido que irá perder a(s) causa(s), com o fim de construir uma reputação de litigante que, desestimulando eventuais litígios futuros, possa garantir lucros, não nas específicas ações ajuizadas, mas na massa de litígios que não se formará por causa do desestímulo das dificuldades do custo e do tempo que se antepõem aos titulares de direitos contra estas instituições. Os atores que operam nessa faixa são repeat players (ou litigantes freqüentes ${ }^{14}$, na linguagem dos pesquisadores), que só assumem tais condutas levados pela perspectiva de ganho em escala ${ }^{15}$. Ou seja, o direito não é a variável mais importante, nem a necessidade de protelar por eventual falta de recursos para adimplir as obrigações; é a perspectiva de ganho em escala o fator decisivo para a ida ou para a permanência no ambiente judiciário.

O tipo de repetição que há nestes casos nem é o da identidade de causas, no sentido de repetir-se em juízo um modelo padrão de empréstimo massificado, por exemplo. É mais sutil, porque pode haver alguma variedade de situações fáticas. Tome-se o exemplo de demandas indenizatórias contra empresas de tabaco em razão de doenças vinculadas ao hábito do fumo. Em certa medida, cada caso é um caso; em outra, todos repetem certas linhas gerais que autorizam inseri-los entre as demandas de massa ${ }^{16}$, em que o fenômeno da repetição, maior ou menor, é um indicativo que possa levar à evidência do direito no início do litígio. Em outras palavras, ao falar nas identidades mais ou menos intensas, se está tratando da maior ou menor homogeneidade dos direitos individuais que surgem no bojo dessas relações massificadas.

\footnotetext{
${ }^{14}$ SANTOS, Boaventura de Sousa et al. Os tribunais nas sociedades contemporâneas: o caso português, cit., p. 71-72.

${ }^{15}$ Mauro Cappeletti e Bryant Garth, referindo-se ao litigante habitual, mencionam que, entre outras variáveis, a economia de escala de quem possui muitas demandas em juízo: "O litigante habitual tem economia de escala porque tem mais casos". CAPPELLETTI, Mauro; GARTH, Bryant. Acesso à justiça. Porto Alegre: Sérgio Antônio Fabris, 1988. p. 25.

${ }^{16}$ Boaventura de Souza Santos et al. citam outros exemplos, como as demandas decorrentes do uso de amianto, nos Estados Unidos, ou as indenizatórias motivadas pela ingestão da talidomida por mulheres grávidas. E arrematam afirmando que "são grupos de processos que partilham características comuns e a mesma história, estão sujeitos às mesmas contingências e inclinam-se para um resultado semelhante" (SANTOS, Boaventura de Sousa et al. Os tribunais nas sociedades contemporâneas: o caso português, cit., p. 81, nota de rodapé $n^{\circ} 57$ ).
} 
Há desdobramentos ainda mais instigantes, que se formam como resultado da teia de complexidade que a atividade econômica produz, quando realizada em larga escala, e que refletem no perfil das demandas que aportam no Judiciário. As grandes sociedades empresárias configuram enormes burocracias, geralmente organizadas como sociedades anônimas. Como tais, para oferecer garantias de transparência ao mercado e aos seus acionistas, formulam práticas que se cumprem, às vezes, não pela lógica da economicidade ou do direito, mas pela lógica da generalização de condutas. Assim, para evitar favorecimento e corrupção no interior da estrutura burocrática, um banco decide, por exemplo, que todos os débitos devem ser cobrados judicialmente dentro de determinado período a contar do vencimento. Essa determinação deflagra condutas que se transformam em massa de ações de cobrança, cujo sentido não é necessariamente o resultado econômico (não raro os custos individuais da demanda são maiores que o resultado, quando há resultado), mas o cumprimento da norma interna. De novo não é o direito o centro motivacional da demanda e, no caso deste exemplo, nem mesmo a vantagem econômica. E não obstante são ações de massa recepcionadas pelo Judiciário em um ritual idêntico a todas as demais cobranças ou execuções.

Outro exemplo que vale referir é o seguinte: os bancos são obrigados a destinar parte dos recursos que arrecadam ao depósito compulsório no Banco Central. Quando ajuízam cobranças, eventualmente liberam o valor equivalente naquela conta do depósito compulsório. O benefício perseguido, então, é o ajuizamento e, dependendo do tipo de cobrança, às vezes é tão-só o ajuizamento.

De modo que o reflexo no Judiciário do modelo capitalista contemporâneo desmembra-se em uma enorme multiplicidade de variáveis, nem sempre suscetíveis de tradução adequada nas categorias do processo.

\subsection{O congestionamento do Judiciário}

A expansão das atribuições do Poder Judiciário decorrentes da operação dos direitos sociais e de sua nova posição no âmbito dos demais poderes, explicados em item anterior, naturalmente contribuiu para o aumento considerável da massa de ações. Na mesma linha, e seguramente com maior volume, os conflitos decorrentes do modelo de produção e consumo em massa de bens e serviços. Em ambas as frentes, contudo, percebe- 
se o avanço das demandas repetitivas. Contra a Administração, as ações propostas para coibir inconstitucionalidades no âmbito tributário, por exemplo, ou para realizar prestações impostas pela Constituição, como o fornecimento de remédios a necessitados. Contra empresas operando em atividades massificadas, a enorme variedade de hipóteses discutidas no tópico anterior.

O Supremo Tribunal Federal orientou pesquisa para mapear as zonas de estrangulamento, detectando que as origens mais importantes do excesso de volume de demandas são ações do Executivo em nível tributário e ações oriundas de atividades econômicas produzidas em regime da intensa massificação, como a telefonia celular, cartões de crédito, financiamentos bancários, planos de saúde etc. Assim se pode dizer, com margem de segurança estatística, que o grande fator de congestionamento do Poder Judiciário são as ações repetitivas. Haverá outras causas, como o desaparelhamento da justiça, a falta de pessoal, o rito excessivamente plenário e demorado do processo de conhecimento, etc., mas mesmo estas se coordenam com o volume demasiado de demandas repetitivas, acarretando mais congestinamento.

Com efeito, o desenvolvimento de um sistema mais avançado de tutelas coletivas, que possa gerar prestação jurisdicional unificada em uma só demanda para todo um conjunto de relações congêneres, seguramente poderá mitigar o congestionamento do judiciário, à medida em que evita a proliferação de ações repetitivas. Mas, como se pretende demonstrar em tópico específico, há um enorme contingente de situações que, embora o traço de repetitividade, não se ajusta aos modelos da jurisdição coletiva. Por outro lado, o sistema brasileiro construiu-se no sentido de ser facultativa a adesão dos particulares à demanda coletiva que trate de direitos individuais homogêneos, que é onde se verifica a maior fonte de repetições. Desse modo, o fenômeno da repetição de ações idênticas não parece próximo de ser superado pela via do direito coletivo, justificando o desenvolvimento de técnicas que possam racionalizar sua abordagem, o que remete ao centro deste estudo, em que se sustenta a viabilidade da antecipação de tutela sem o requisito da urgência em ações repetitivas, significativo instrumento de efetividade da jurisdição, tanto no aspecto individual de cada caso particular, como no aspecto da pacificação social. 
Por fim, o congestionamento produziu no Judiciário progressiva reação com práticas massificadas de prestação jurisdicional, naquilo que se vem denominando a "burocratização da justiça" 17 , que merece análise detalhada.

\subsection{A burocratização da justiça: “jurisdição convencional" e "jurisdição massificada"}

A independência do juiz, as garantias da magistratura e o padrão ritual e principiológico do processo são características estruturais que deveriam afastar o Judiciário da estrutura massificada e burocrática, em que a hierarquia, a impessoalidade, a divisão de tarefas e a repetição de condutas são as notas definidoras ${ }^{18}$. Essa diferença ontológica entre jurisdição e burocracia cede, no entanto, justamente quando se apresentam as repetições.

Isso porque as primeiras decisões se transformam em paradigmas, replicados nos casos posteriores que se apresentam com idêntica estrutura. Seria irracional que o magistrado tratasse pessoalmente de cada um desses casos sucessivos da mesma forma que tratou do primeiro ou do segundo, examinando cada peça dos autos e envolvendo-se em discussões com todo o ritual do processo convencional. Aliás, se agisse assim, provavelmente estaria sozinho, porque nem as partes, nem o Ministério Público, quando aí atua, estão dispostos a um amplo diálogo nas ações repetitivas. Em outras palavras, essa específica burocratização do serviço jurisdicional é consequiência da própria anatomia de um universo litigioso cuja dinâmica se define justamente pela repetição. E redunda na construção de padrões de resposta jurisdicional, que depois serão reproduzidos em série pelo staff de auxiliares.

Em suma, tudo se justifica na idéia de eficiência e racionalidade para responder à demanda social. É um contexto que não passa ao largo, vale lembrar, do acesso à justiça. Tanto mais aberta à população, tanto mais democratizada, mais a justiça tende a ajustar-se aos modelos da própria sociedade. E, se a massificação é um fenômeno inseparável da

\footnotetext{
${ }^{17}$ Sobre o tema da burocratização, vide FRANCO, Alberto Silva. O perfil do juiz na sociedade em processo de globalização. In: MORAES, Maurício Zanóide de (Org.). Estudos em homenagem à Professora Ada Pellegrini Grinover. São Paulo: DPJ Ed., 2005. p. 809-812.

${ }^{18}$ WEBER, Max. Ensaios de sociologia. 5. ed. Rio de Janeiro: LTC, 2002. p. 140-147.
} 
dinâmica social, é inevitável que a maior abertura da justiça aos conflitos sociais comporte a sua conseqüente massificação ${ }^{19}$.

Mas apenas uma parte das demandas que transitam pelo Judiciário tem essa configuração repetitiva, seguramente a maior parte, em termos puramente quantitativos. $\mathrm{O}$ restante constitui o enorme contingente de outras demandas em que a jurisdição tem de operar-se pelo ritual clássico do processo. Existem, portanto, do ponto de vista operacional, duas categorias que podem ser destacadas na jurisdição contemporânea: a que se produz observando o diálogo crítico do julgador com as partes, o contato pessoal com os fatos da causa, a ponderação e o próprio sentimento do juiz, e que se pode denominar de "jurisdição convencional", atenta aos princípios basilares do processo (contraditório, ampla defesa e devido processo legal), e a "jurisdição massificada", em que se produz, mediante a repetição burocratizada e em série, uma decisão-padrão. O modelo de jurisdição “convencional” é adequado para os litígios não repetitivos e para resolver os primeiros casos das demandas repetitivas que irão definir as decisões-padrão.

Não se trata de uma diferença ontológica com base na da qual se estaria afirmando a existência de dois tipos de jurisdição. Por isso se disse no parágrafo anterior que o critério classificatório é operacional, girando em torno do modo de realizar-se: uma diferença que decorre da adaptação do mesmo ser (a jurisdição) às circunstâncias particulares de dois tipos de demanda social.

"Jurisdição convencional" e "jurisdição massificada", ou, numa imagem de puro apelo didático: "jurisdição de varejo" e "jurisdição de atacado". O problema não reside no fenômeno, considerado em si mesmo, mas na contaminação de uma realidade pela outra, definindo, aí sim, um quadro patológico da burocracia judiciária.

As novas realidades sociais não emergem em um dado momento já prontas e perfeitamente delimitadas. O novo emerge aos poucos da realidade estabelecida, gestandose nela e com ela convivendo progressivamente. Foi assim que a massificação penetrou o Judiciário, aos poucos, sendo recepcionada pelo modelo processual construído com base no modelo dos litígios individuais peculiares.

Com a aceleração do ritmo da economia e, no Brasil, com a privatização, que gerou a transferência para a atividade privada de amplos serviços massificados antes sob o

\footnotetext{
${ }^{19} \mathrm{Na}$ definição de Galeno Lacerda, "tudo isto, enfim, que define a cultura e a civilização de um povo, há de retratar-se no processo em formas, ritos e juízos correspondentes”. LACERDA, Galeno de. Processo e cultura. Revista de Direito Processual Civil, São Paulo, ano 3, p. 75, 1962.
} 
controle do Estado, aumentou dramaticamente o volume de ações repetitivas. E a reação do Judiciário a essa crescente invasão foi ajustar-se a ela, intensificando a burocracia na operação dos juízos. Um ajuste que, entretanto, não procurou orientar-se pelas características internas dos casos repetitivos, limitado ao cumprimento de todo o ritual do processo clássico e incluindo algumas adições rituais criadas pela prática judiciária, que significam redobrados retardamentos, tais como as intimações generalizadas para que as partes digam as provas que pretendem produzir. Nem haveria como ser diferente, talvez, pela natureza atomizada da justiça, em que cada juízo é uma unidade independente, impedindo a reação imediata do sistema judiciário como um todo, orientada por vetores generalistas.

Em pouco tempo, o modelo burocrático expandiu-se. E o fez em duas frentes. Primeiro, por conta da vocação expansiva presente na essência mesma da burocracia, que avança no interior do agente, automatizando-o ${ }^{20}$. Em segundo lugar, porque o aumento de processos produz a necessidade de planejamento cada vez mais baseado em rotinas, que é o próprio planejamento burocrático.

Então, ao invés de se separarem esses casos dos demais, para serem tratados burocraticamente e em apartado, aconteceu o contrário. Passou-se a prestar jurisdição da mesma forma em toda a massa de ações, e o modelo excessivamente burocrático se implantou onde não poderia, na "jurisdição convencional”, gerando o quadro patológico de que se falou acima.

Owen Fiss, jurista norte-americano, ao estudar a burocracia na justiça dos Estados Unidos, destaca duas acepções da patologia burocrática ${ }^{21}$. A automatização do agir limita a crítica do agente ao cumprimento da norma. Orientado a exigir o "carimbo" no documento, o agente não sabe por que o exige, e o exigirá sempre, mesmo quando, no caso particular, a exigência possa desafirmar justamente o sentido pelo qual a norma foi feita. É "a norma pela norma".

Outra característica é a desconexão moral que a burocracia tende a gerar, quando a divisão de tarefas dilui o ato do agente no conjunto de atos praticados pelos vários atores, de modo a desconectar a ação individual do resultado. É nessa acepção, mais que na outra, que o problema da burocracia judiciária se acentua. Em um exemplo real, entre tantos da

\footnotetext{
${ }^{20}$ Sobre o "caráter indestrutível" e expansivo da bucrocracia: WEBER, Max. Ensaios de sociologia, cit., p. 160-161.

${ }^{21}$ FISS, Owen. Um novo processo civil: estudos norte-americanos sobre jurisdição, cit., p. 175-189.
} 
mesma natureza que se produzem todos os dias nos foros, determinado funcionário não juntou aos autos a justificativa que um devedor de alimentos apresentara ao juiz. Conclusos os autos, a falta da justificativa acionou, por parte do assessor, a decisão-padrão ordenando fosse preso o alimentante. E o juiz assinou a ordem, entre outras tantas assinaturas que a rotina lhe impunha todos os dias. O mandado foi processado na central respectiva, e um oficial de justiça cumpriu a norma e realizou a prisão. Informado no outro dia, o advogado procurou o juiz e foi recebido pelo assessor encarregado da triagem dos "assuntos" dos que procuravam o gabinete, que o instruiu a peticionar de imediato comprovando a entrega da justificativa, dispensando a audiência com o magistrado. Ao fim, sobreveio o relaxamento da prisão.

Situações do tipo dessa importam mais ser lembradas pelo seu apelo didático, porque o mal maior nem está nesses extremos, mas no enorme conjunto de casos que se processam burocraticamente, aos quais a falta de um apelo, tal como a prisão, inviabiliza a reação da cadeia burocrática.

O mesmo Owen Fiss adverte, em passagem em tudo aplicável ao direito brasileiro:

"é aqui que a burocracia emerge como uma estrutura social que torna possível, facilita e talvez até cause o uso irracional do Poder Público (...). Primeiramente, por meio da fragmentação e compartimentalização das tarefas, a burocracia isola aqueles que agem dentro dela de experiências educacionais críticas (...). Em segundo lugar, a burocracia tende a tornar a responsabilidade difusa. Nenhum indivíduo sozinho ou grupo de indivíduos identificáveis assume a responsabilidade integral pela ação da organização. A ação da organização, é o produto sintético da ação dos indivíduos dentro dela",22.

O juiz haverá de assumir formalmente a responsabilidade, no caso da prisão do alimentante, mas não se sentirá integralmente responsável, porque foi o funcionário que deflagrou o erro e, em última análise, foi o excesso de processos que fez o funcionário errar. E não terá o sentimento concreto de sua ação, porque o drama do aprisionamento foi protagonizado pelo oficial de justiça, e o advogado foi recebido pelo assessor. Não haverá, no episódio, pelo menos não na intensidade devida, a experienciação das culminâncias do erro, que possibilitam e até obrigam o agente a rever suas práticas. E o caso se diluirá como um acidente cartorário, no máximo com a admoestação do funcionário para que não repita o mesmo erro.

\footnotetext{
${ }^{22}$ FISS, Owen. Um novo processo civil: estudos norte-americanos sobre jurisdição, cit., p. 180-181.
} 
Em paralelo, uma outra ordem de circunstâncias concorre para o desvirtuamento da jurisdição burocratizada: o sistema de duplo grau de jurisdição, aliado à idéia de execução só após o trânsito em julgado, contribui para que o juiz singular não enxergue eficácia das suas sentenças, transformado, como está ao sentenciar, em um posto de passagem para o Tribunal. Além de desestimular a qualificação do julgado, isso desconecta mais ainda o juiz do resultado de sua ação, reduzindo o sentido do seu agir à domesticação das pilhas de processos mais do que à solução dos casos.

Em sugestiva imagem, Calamadrei capturou idêntico fenômeno na Itália, já nas primeiras décadas do século XX:

"En realidad, especialmente en los tribunales de primera instancia de las grandes sedes, los litigantes mismos comprenden que a magistrados reducidos a la función casi manual de fabricantes de sentencias en serie no se les puede pedir la docta valoración del caso jurídico, la elegante discusión de todos los aspectos, que puede salir solamente de largo estudio e y de tranquilo recogimiento de pensamiento. Hoy en dia, el trofeo a que aspira quien se atreve a emprender la "lucha por el derecho" nos es ya tanto una sentencia justa e bien motivada, cuanto una sentencia, cualquiera que sea, que le permita acudir al juez de apelación. "23

Chegando aos tribunais, o ritmo dos julgamentos é tanto ou mais burocratizado, seja pela atuação ainda mais intensa do staff de auxiliares, seja pelo distanciamento ainda maior do magistrado em relação à concretude da causa e dos seus personagens. Nem o ritual do julgamento colegiado e público, nem a defesa oral das posições das partes amenizam, pois cada vez mais essas práticas tendem a esvaziar-se, engolidas pela tendência do julgamento monocrático nos tribunais.

Por certo o quadro aqui apresentado não é sempre o mesmo. Há zonas de maior e menor estrangulamento. Há organizações judiciárias mais e menos abarrotadas. Há juízes que, por características pessoais ou à custa trabalho redobrado, desenvolvem métodos pessoais de separar no volume total das causas sob sua jurisdição, aquelas que exigem um tratamento mais detido, das outras, que permitem a solução massificada. Mas em linhas gerais, todo o aparelho da justiça vai sendo progressivamente atacado pelas deformações da burocracia.

Como referido acima, o juiz contemporâneo exerce poder político em larga escala, fruto da evolução social que se processou ao longo dos anos. Mas o atual estágio da

\footnotetext{
${ }^{23}$ CALAMANDREI, Piero. El procedimiento monitorio. Buenos Aires: Bibliográfica, 1946. p. 188.
} 
realidade prática da jurisdição ameaça a consciência crítica do poder sobre si mesmo e, portanto, a própria natureza política da atividade jurisdicional ${ }^{24}$. Ou, nas palavras de Owen Fiss, a "burocratização aumenta a possibilidade de que a assinatura do juiz - na sentença - não tenha o devido significado, ou seja, de que o juiz esteja exercendo poder sem se engajar genuinamente no diálogo do qual advém sua autoridade” ${ }^{, 25}$. E, nessa linha de agigantamento e de burocracia, dinamiza-se o risco de que o Judiciário acabe se restringindo a um grande balcão de serviços, a exemplo da burocracia administrativa.

Uma das questões centrais desse quadro é a falta de segregação dos dois tipos de massa de ações, as repetitivas e as convencionais, reservado às primeiras o modelo operacional burocratizado, a partir dos primeiros julgamentos, mediante repetição massiva nos demais. Como, aliás, já acontece na prática, embora empiricamente e, pois, sem a clareza científica e o reconhecimento institucional que possibilite generalizar como política judiciária o enfrentamento dos processos individuais idênticos como conjuntos, com técnicas de verdadeira gestão, mediante o uso de modelos administrativos, recurso à planificação de conjuntos, estatísticas, metas, etc, no qual o juiz seja um coordenador assumido como tal, e o staff, a equipe de gestão dos standards formulados pelo magistrado ${ }^{26}$. Um ambiente próprio para adaptar a anatomia da massa litigiosa ao processo civil, desbastando aquilo que, a partir de certa altura, passa a ser desnecessário ${ }^{27}$.

\footnotetext{
${ }^{24}$ Vittorio Denti, em artigo muito citado sobre a crise da justiça, verifica a desorientação dos juízes, e o risco de "perda de identidade" por parte deles, premidos pelas transformações sociais que, no dizer do jurista, talvez justificassem denominar, usando uma metáfora de Rodotà, mais do que apenas "crise", como "catástrofe" da instituição judiciária. Catástrofe, ele explica, no sentido de "descontinuidade" do fenômeno (no caso o fenômeno da justiça, como a conhecemos). “(...) capire in qual modo i problemi di una società in trasformazioni, come è quella italiana, si reflettono sui problemi della giustizia, e se siano vicini al vero coloro che (come Stefano Rodotà in um recente dibattito) ritengono che si debba parlare non di 'crisi', ma addirittura di 'catastrofe': proposizione, questa, in cui è presente l'eco de un'altra teoria pure di moda oggi, quella delle catastrofi, la cui volgarizzazione trascura che 'catastrofe', nell'ambito matematico in cui la teoria è stata formulata, significa essenzialmente discontinuità dei fenomini." DENTI, Vittorio. Crisi della giustizia e crisi della societtà. Rivista di Diritto Processuale, Padova, n. 4, p. 585, 1983. Tirante o eventual excesso da metáfora, o fato é que o artigo descreve com peculiar precisão a crise da justiça na linha desenvolvida neste estudo, e o problema dos juízes no interior da crise.

${ }^{25}$ FISS, Owen. Um novo processo civil: estudos norte-americanos sobre jurisdição, cit., p. 165.

${ }^{26}$ A tentativa de descrever, organizar e difundir tecnologia de gestão para conjuntos de litígio no interior do Judiciário encontra recentes iniciativas de alto valor teórico e prático. É exemplo a obra de SCHMIDT, Ricardo Pippi. Administração judiciária e os juizados especiais cíveis: o caso do Rio Grande do Sul. Porto Alegre: Tribunal de Justiça do Estado do Rio Grande do Sul, 2008, e, ainda, STUMPF, Juliano da Costa. Poder Judiciário: morosidade e inovação. Porto Alegre: Tribunal de Justiça do Estado do Rio Grande do Sul, 2009.

${ }^{27}$ Já há reações nessa linha, embora ainda incipientes na prática de tribunais brasileiros. O exemplo talvez mais importante seja o do Tribunal de Justiça do Rio de Janeiro, que tem aplicado processos de gestão, inclusive com certificações próprias do mundo da administração (NBR ISO 9001:2001), definição de metas de produtividade cartorárias, etc. A $13^{\text {a }}$ Vara Cível da Capital carioca, já certificada pelo ISO 9001, constitui "uma ilha de excelência", no dizer do Presidente do TJRJ, em termos de celeridade na prestação da jurisdição, mercê do uso de técnicas de gestão. Mas o destaque mais importante no TJRJ para a linha de
} 
No outro extremo, os processos convencionais, em que cada caso é um caso, marcados por autêntica incerteza, a exigir o envolvimento significativo do juiz, com atividades de apoio rarefeitas das assessorias. E, ao centro, uma gama de outros processos entre os dois extremos, em que não impera a incerteza em grande escala nem a evidência total.

Prosseguindo, essa mesma falta da segregação dos dois tipos de jurisdição, não apenas como ato físico de separar autos, mas, antes, como cultura judiciária, redunda em uma percepção equivocada da sociedade - e do próprio Judiciário - sobre o índice real de seu congestionamento, o que, a par de gerar um certo pessimismo que corrói a autoconfiança do sistema, pode determinar a distorção de alterações legislativas destinadas a domesticar os excessos, na medida em que práticas de generalização possam ser aplicadas em processos da "jurisdição convencional”.

Vale anotar que o sistema processual já desperta, embora em caráter setorial, para o desenvolvimento de técnicas que conduzam à separação de litígio de massa para julgá-los como conjunto. Exemplo marcante é o da Lei 11.672, de 08-5-2008, que acrescentou o art. 543-C ao Código de Processo Civil, instituindo regime especial para o tratamento de recursos repetitivos no Superior Tribunal de Justiça. Em suma, a idéia é identificar casos idênticos do ponto de vista da mesma questão de direito e efetivar o julgamento em um ou mais recursos representativos da controvérsia, prolatando a decisão-padrão que depois é disseminada aos demais casos, que aguardam suspensos.

Trata-se de mecanismo cuja eficiência poderá significar um corte drástico no congestionamento daquele Tribunal, conforme manifestação de seu Presidente, para quem a "escolha de dez temas repetitivos poderá significar a eliminação de 120 mil recursos $(\ldots)^{, 28}$.

Finalizando este tópico, importa dizer que uma coisa é a técnica de separar segregar - os litígios de massa para tratá-los como conjunto, propiciando a aceleração do processo com a outorga da tutela definitiva em espaço mais curto de tempo, como faz a Lei

raciocínio aqui desenvolvida é a separação, que vem tentando fazer, de processos de massa suscetíveis de avançada gestão, vinculados fundamentalmente a operadoras de telefonia, com aplicação adaptada do processo civil. Todas as informações sobre essas iniciativas constam no site Tribunal de Justiça do Rio de Janeiro. Disponível em: <http://www.tj.rj.gov.br/corregedoria/serviços>. Acesso em: 29 jan. 2008, acerca das "30 empresas mais acionadas nos juizados" e sobre o "Projeto Expressinho".

${ }^{28}$ Manifestação do Ministro Cesar Asfor Rocha, presidente do STJ, em entrevista publicada no site da internet daquele Tribunal. Superior Tribunal de Justiça. Disponível em: <www.stj.gov.br>. Acesso em: 29 out. 2008. 
11.672/08; outra é recolher nas repetições, propriamente, como se propõe neste trabalho, elementos para viabilizar a outorga de uma tutela diferenciada (antecipada), que, embora não definitiva, propicia ganho considerável de efetividade na prestação jurisdicional, com reflexos não apenas no interior de cada demanda individual, mas na própria legitimação do Judiciário, como poder, na sua relação com os jurisdicionados.

Guardadas as diferenças, o fato é que ambas as técnicas convergem na finalidade de enfrentar as patologias que a massificação produz no interior do sistema judiciário.

\section{O cenário do processo}

A evolução do processo é naturalmente no mesmo sentido da linha evolutiva da jurisdição. E a sua crise, também.

No contexto do ideário liberal, o processo civil liberta-se das velhas praxes e adquire autonomia a partir dos estudos sobre a ação e sobre a relação processual. Volta-se então para si mesmo, e a dogmática se desenvolve com intenso trabalho de lapidação dos institutos $^{29}$. O paradigma é o litígio individual; a culminância é a declaração do direito em caráter definitivo, e o sentido vetorial, a segurança jurídica. É o contexto apropriado para um processo aberto à ampla discussão, extremamente plenário ${ }^{30}$. E também para posicionar os atos de execução sempre depois da obtenção da certeza pela coisa julgada. É o processo ordinário, que constitui o paradigma do direito processual da Europa continental e America Latina, a chamada civil law.

\footnotetext{
${ }^{29}$ José Carlos Barbosa Moreira salienta que a fase de estruturação do processo civil exigiu um olhar-paradentro dos juristas, para construir o seu edifício teórico: "Era natural que, ao longo de um semelhante processo de amadurecimento, os maiores cuidados se dirigissem à construção de estruturas dogmáticas firmes. Tal prioridade refletia, aliás, o conceptualismo que reinava, quase absoluto, no ambiente jurídico da época.” MOREIRA, José Carlos Barbosa. Tendências contemporâneas do direito processual civil. Revista da Ajuris, Porto Alegre, ano 12, n. 34, p. 116, jul. 1985.

${ }^{30}$ Segundo a descrição de Victor Fairen Guillén: "El juicio ordinario, se basa y ha basado siempre, en el deseo de acabar para siempre, com el litigio entre las partes de manera judicial, de tal modo que non sea posible un nuevo proceso sobre el punto resuelto (....) Por ello es desear em él la mayor estensión en el desarrollo de las pretensiones, de tal modo que todas las relaciones litigiosas sean resueltas. Por ello se permite a las partes completar del mejor modo posible sus sistemas de denfesas; por ello son amplios los medios de impugnación y los plazos que los hacen accesibles; por ello se da a eligir a las partes entre toda una diversidad de medios de prueba. El conjunto justifica uma copiosa serie de formalismos, preclusiones, providencias jurisdiccionales, etc. El antiguo solemnis ordo iudiciarus respondia a este tipo procedimental” FAIREN GUILLÉN, Víctor. El juicio ordinário y los plenarios rápidos. Barcelona: Bosch, 1953. p. 53.
} 
Trata-se de um modelo que se movimenta em torno da justiça do caso concreto, colocando o juiz na posição de espectador do litígio. Pressupõe uma sociedade mais ou menos coesa e equilibrada, sem grandes diferenças sociais, com um conjunto de normas estável que advenha do seio dessa sociedade e seja a sua legítima expressão ${ }^{31}$.

Outra característica do modelo ordinário é a sua pretensão à universalidade. Vale dizer, é um mecanismo que se pretende apropriado para veicular quaisquer tipos de demandas, independentemente das peculiaridades da lide. Trata-se de um reflexo da idéia de que a ação processual, sendo independente do direito material, tem características próprias determinadas só e só pelo mundo do processo $^{32} 33$.

\subsection{Variações da realidade e a crise do processo ordinário}

Em instigante estudo da década de sessenta, Galeno Lacerda examina a linha evolutiva do processo tomando como ponto de referência a dicotomia individual/coletivo ${ }^{34}$. Anota a tensão entre os interesses da sociedade e dos indivíduos em relação aos conflitos. Estes, almejando justiça; aquela, necessitando rápida decisão, à medida em que o somatório dos conflitos privados os transforma em tema de interesse público, impondo ao Poder a pacificação social. Desde o ponto de vista do coletivo, a decisão nem sempre pressupõe justiça ${ }^{35}$. Bem por isso há momentos históricos em que a força da autoridade soluciona a conflituosidade privada por critérios alheios ou distantes do valor justiça. Assim, por exemplo, a tradição do direito germânico primitivo. Orientados pela necessidade de permanente prontidão bélica, os grupos sociais não dispunham de tempo

\footnotetext{
${ }^{31}$ Nesse sentido, FISS, Owen. Um novo processo civil: estudos norte-americanos sobre jurisdição, cit., p. 49. Também Eduardo Faria, estudando no interior do direito as normas e os princípios, relaciona a estabilidade social, maior ou menor, a um direito com alto grau de consenso e, por isso mesmo, mais claro. No outro pólo, os contextos instáveis, "momentos de profundo dinamismo social” em que o direito não tem como se construir com um nível de precisão acentuado, fruto de consenso, inclinando-se para a regulação dos princípios menos do que pela das normas.

${ }^{32}$ É o que a visão autonomista do processo identifica como o caráter transubstancial das normas de processo, "no sentido de se aplicarem indistintamente a várias áreas de direito material” (SALLES, Carlos Alberto (Org.). Processo civil e interesse público. São Paulo: Associação Paulista do Ministério Público; Ed. Revista dos Tribunais, 2003. p. 47).

${ }^{33}$ José Roberto dos Santos Bedaque aponta a superação dessa tendência, assinalando que "Não se admite mais o procedimento único, rígido, sem possibilidade de adaptação às exigências do caso concreto". BEDAQUE, José Roberto dos Santos. Direito e processo: influência do direito material sobre o processo. 3. ed. São Paulo: Malheiros Ed., 2001. p. 60.

${ }^{34}$ LACERDA, Galeno de. Processo e cultura, cit., p. 74-86.

${ }^{35}$ LACERDA, Galeno de. Processo e cultura, cit., p. 77-78.
} 
para empregar na investigação da justiça dos casos individuais, e necessitavam resolver os conflitos em curto espaço de tempo, adotando rituais próprios para tal finalidade.

Na outra ponta, experiências históricas em que o individual se impôs ao coletivo ${ }^{36}$, emergindo então o valor justiça (do caso concreto) como centro da atenção e refletindo-se em um processo aberto à ampla defesa, cuja culminância é o processo ordinário.

Por fim, anota Galeno Lacerda que a hegemonia ou a hipertrofia de qualquer desses pólos (individual e social) é inviável, pois degenera em autoritarismo, ou em um processo tão demorado que não atende nem aos anseios do indivíduo por justiça, nem aos interesses sociais de cessação da conflituosidade privada $^{37}$.

A crise do processo ordinário se insere nesse contexto. Fundado em perspectiva ideológica individualista, ele se revelou insuficiente para expressar a realidade social, que com o passar do tempo foi-se mostrando mais complexa nas grandes diferenças de caráter econômico, étnico, racial e outros, a exigir igualdade substancial arbitrada pelo juiz. Assim na evolução dos direitos sociais - tentativa de estender a todos a condição de igualdade substancial -, que não se ajustam ao modelo de um processo concebido para dirimir conflitos privados; na massificação; na evolução política, que alarga enormemente as funções dos juízes, sejam aquelas de controle dos demais poderes, sejam atividades promocionais que têm de se realizar por dentro do processo; na emergência de direitos inclusive sem titular definível, pertencentes a todos e a nenhum, que são os direitos difusos. Um conjunto expansivo, que Carlo Guarnieri e Patrizia Pederzoli descrevem na seguinte linha evolutiva:

"chediamo alle corti di difendere le nostre libertà, di allentare le tensioni
razziale, da condannare la guerra e l'ínquinamento, di proteggerci dagli
abusi dei poteri publici e dalle nostre tentazioni private, d'inflinggere
pene.... di compensare le differenze fra gli individui, di resuscitare
l'economia, di tutelarci prima di nascere, di sposarci, di accordarci il
divorzio e se non próprio di sppelircci, quanto meno di assicurare che le
spese del nostro funerale vengono pagate." 38

\footnotetext{
${ }^{36}$ Rodolfo de Camargo Mancuso salienta o aspecto cíclico da evolução ao longo da história, alternando os valores individual e coletivo: "Eis aí, portanto, uma demonstração da 'evolução cíclica dos interesses': movimentam-se alternando os primados do coletivo e do individual. MANCUSO, Rodolfo de Camargo. Interesses difusos: conceito e legitimação para agir. 6. ed. São Paulo: Ed. Revista dos Tribunais, 2004. p. 50 .

${ }^{37}$ LACERDA, Galeno de. Processo e cultura, cit., p. 80 e 83.

${ }^{38}$ GUARNIERI, Carlo; PEDERZOLI, Patrizia. La democrazia giudiziaria. Bologna: Soc. Editrice il Mulino, 1997. p. 9.
} 
Enfim, toda uma gama de circunstâncias que, progressivamente, vai produzindo tensão no processo em busca de novas fórmulas adequadas ao trânsito de uma conflituosidade que se apresenta com traços cambiantes e heterogêneos, enquanto o tempo avança, e a sociedade se transforma.

A maior visibilidade dessa crise do processo se deu na demora da prestação jurisdicional $^{39}$. Há outros aspectos, tanto ou mais relevantes, como, por exemplo, a incompatibilidade da sua estrutura para dinamizar as ações coletivas. Mas isso só muito recentemente tomou espaço no debate, ainda imerso na grande questão da demora considerada em si mesma. Por aí o debate polarizou-se entre a segurança jurídica, a exigir tempo de pesquisa, diálogo e meditação - e, conseqüentemente, a impor demora-, e a efetividade dos direitos, a exigir tempestividade na prestação jurisdicional.

Outro aspecto da crise do processo ordinário está em que, sendo ele meio por intermédio do qual a jurisdição se realiza, submete-se e deve acomodar a renovada compreensão da realidade jurisdicional contemporânea, que incorpora, além do escopo jurídico, em que se insere o arbitramento dos conflitos interpessoais clássicos, também escopos políticos e, mais que tudo, o escopo social da pacificação. Tudo isso traduz um cenário de profundas alterações estruturais no processo. Por exemplo: o papel passivo que se imputava ao juiz clássico refletiu-se nas normatizações de todos os quadrantes do processo, desde o instituto da prova até os atos de execução. Alterado o papel do juiz, em razão do percurso histórico mencionado no início, alteradas suas atribuições e deveres, no sentido de ampliar a iniciativa própria no atingimento dos fins do processo, aqueles esquemas normativos formulados sob pontos de referência que já não existem mais, naturalmente entram em choque com a realidade e também produzem a crise do processo ordinário.

Esse debate sobre as insuficiências do processo ordinário, que já é antigo, sugere a reflexão sobre o porquê, ainda hoje, ele permanece vivo, embora já profundamente alterado e em ritmo de permanente alteração, tanto no Brasil como em todos os países da chamada civil law.

\footnotetext{
${ }^{39}$ Giuseppe Tarzia, examinando o problema da razoável duração do processo, assinala ser o tema "certamente il più rilevante nell'attuale situazione della giustizia civile” na Europa. TARZIA, Giuseppe. L'art. 111, cost. e le garanzie europee del proceso civile. Revista de Processo, São Paulo, ano 26, n. 103, p. 169, jul./set. 2001. Na mesma linha, Carlos Alberto Alvaro de Oliveira: “o tempo tornou-se em nossos dias um dos parâmetros fundamentais da justiça (...)”OLIVEIRA, Carlos Alberto Alvaro de. Efetividade e processo de conhecimento. Revista da Ajuris, Porto Alegre, v. 26, n. 75, p. 134, set. 1999, e José Rogério Cruz e Tucci: "É bem de ver que o fator tempo, que permeia a noção de processo, constitui, desde há muito, o principal motivo da crise da justiça (...)”. CRUZ E TUCCI, José Rogério Garantia da prestação jurisdicional sem dilações indevidas, como corolário do devido processo legal. Revista de Processo, São Paulo, v. 17, n. 66, p. 73, abr./jun. 1992.
} 
A resposta remete para fora do mundo do processo.

Os valores elaborados no período do liberalismo (liberdade, igualdade propriedade, autonomia da vontade), que constituem os direitos civis (de primeira geração), permanecem vivos no mundo contemporâneo. Mesmo os direitos sociais (a segunda geração ${ }^{40}$ podem ser encarados como extensão daqueles valores individuais para toda a sociedade $^{41}$, o que comprova o quanto é caro ao mundo contemporâneo capitalista o ideário que está à base do procedimento ordinário. São elementos da cultura do povo, incorporados profundamente na consciência coletiva. E o processo ordinário sobrevive justamente pela legitimidade que alcança ao refletir aquele conjunto de valores em sua estrutura mais profunda. Assim na ampla defesa e no devido processo legal, por exemplo, que, em última análise, corporificam esquemas como o da execução (concretização) dos direitos só após o julgamento, da justiça do caso concreto e da segurança jurídica.

Ainda acerca da sobrevivência da estrutura ordinária como paradigma do processo contemporâneo, não obstante alterações muito profundas, vale lembrar as lições do filósofo norte-americano Thomas Kuhn sobre as revoluções científicas como movimentos de

\footnotetext{
${ }^{40}$ A doutrina do direito constitucional consagrou a classificação dos direitos humanos em três gerações ou dimensões. Segundo Ingo Wolfgang Sarlet, a primeira dimensão, que em síntese é constituída de direitos civis e políticos, surgiu e se afirmou como "direitos do indivíduo frente o Estado, mais especificamente como direitos de defesa, demarcando uma zona de não-intervenção do Estado e uma esfera de autonomia individual em face de seu poder. (...) são dirigidos a uma abstenção e não a uma conduta positiva por parte dos poderes públicos”. E exemplifica com os direitos à vida, à liberdade, à propriedade e à igualdade perante a lei, mais tarde complementados por outras "liberdades", como a de imprensa, de reunião, de manifestação, de associação; ainda o direito de votar e ser votado e as garantias processuais (devido processo legal, direito de petição, etc). SARLET, Ingo Wolfgang. A eficácia dos direitos fundamentais. Porto Alegre: Livraria do Advogado, 2006. p. 54-55. A segunda dimensão, que se resume em direitos econômicos, sociais e culturais, traduz a finalidade da realização da justiça social; na expressão de Paulo Bonavides, "nasceram abraçados ao princípio da igualdade" (Curso de direito constitucional. 12. ed. São Paulo: Malheiros Ed., 2001. p. 518), porque significam a transição entre igualdade formal da primeira dimensão, para a igualdade substancial da segunda, "resultado das reivindicações dos desprivilegiados a um direito de participar do 'bem-estar social' (...). Tais direitos - como o direito ao trabalho à saúde, à educação - têm como sujeito passivo o Estado" embora o titular seja, como na primeira dimensão, "o homem na sua individualidade”: LAFER, Celso. A reconstrução dos direitos humanos: um diálogo com o pensamento de Hannah Arendt. 6. reimpr. São Paulo: Companhia das Letras, 2006. p. 127. Os direitos de terceira geração, também denominados de solidariedade ou de fraternidade, encontram-se ainda em fase embrionária. Segundo Norberto Bobbio, trata-se de "uma categoria, para dizer a verdade, ainda excessivamente heterogênea e vaga, o que nos impede de compreender do que efetivamente se trata" (BOBBIO, Norberto. A era dos direitos. Rio de Janeiro: Campus/Elsevier, 2004. p. 5). No entanto alguns elementos centrais e alguns consensos doutrinários permitem identificá-los como direitos cuja titularidade é difusa. O exemplo mais utilizado para sua identificação é o do meio ambiente equilibrado. Também o direito à paz, ao desenvolvimento (principalmente das populações mais pobres), à autodeterminação dos povos, etc.

${ }^{41}$ Conforme Mauro Cappelletti: “No campo dos direitos humanos fala-se dos direitos sociais, como 'direitos humanos da segunda geração'. Eles tendem principalmente a fazer que os direitos tradicionais ou 'da primeira geração' (...) sejam extensíveis a todos (...)” CAPPELLETTI, Mauro. Problemas de reforma do processo civil nas sociedades contemporâneas. Revista de Processo, Sao Paulo, v. 17, n. 65, p. 130, jan./mar. 1992.
} 
substituição de paradigmas. O cenário de seu pensamento não é aplicável ipsis litteris à ciência do direito, mas vale para proporcionar uma visão de fora do universo jurídico.

Os paradigmas, segundo ele, são máximas científicas que atingem, em determinado momento, um alto nível de consenso e conseqüente autoridade. A partir daí, orientam o trabalho científico, que então passa a lapidar e expandir o material bruto do paradigma, de forma a articulá-lo na ciência e na natureza ${ }^{42}$. Um dos pontos centrais da articulação cientifica são as anomalias, ou seja, pontos em que o paradigma aparentemente se desafirma, ou problemas que ele não resolve. Esse é o trabalho mais árduo do cientista, ou seja, articular o paradigma superando as situações de anomalia ${ }^{43}$.

A revolução, como visto, consiste na substituição do paradigma quando - e se emergir um novo consenso. Mas, anota o cientista, não há hipótese de puro abandono de um paradigma, simplesmente porque a ciência não resolve as anomalias que o enfraquecem. Enquanto não sobrevier outro modelo, a orientação do pensamento permanecerá vinculada ao antigo consenso, convivendo com suas deficiências, porque a falta de um elemento orientador é mais prejudicial para a ciência do que o desgaste do paradigma científico ${ }^{44}$. Por outro lado, há situações em que "a ciência normal acaba revelando-se capaz de tratar o problema que provoca a crise, apesar do desespero daqueles que o viam como o fim do paradigma existente" 45

Com as devidas ressalvas, considerando que a construção é mais adequada às ciências naturais, o fato é que a estrutura essencial da ordinariedade, pelo grau de legitimidade que ainda conserva, porque reflete uma cultura vigente, sobrevive, embora desgastada, inclusive porque não há outro modelo que dê conta de organizar amplamente o universo do processo. Em paralelo, tal como na visão de Thomas Kuhn, os cientistas se ocupam da tarefa permanente de encontrar meios para minimizar a anomalia da demora, mediante a construção de esquemas que possam, sem o sacrifício dos valores essenciais por trás da ordinariedade, atalhar o caminho desde a propositura da demanda até a fruição concreta do direito reclamado $^{46}$. O conteúdo do próximo capítulo procura descrever as linhas gerais dessas iniciativas, dentre as quais se inclui o presente trabalho, cujo sentido é

\footnotetext{
${ }^{42}$ KUHN, Thomas. Estrutura das revoluções científicas. 3. ed. São Paulo: Perspectiva, 1992. p. 44-45.

${ }^{43} \mathrm{KUHN}$, Thomas. Estrutura das revoluções científicas, cit., p. 101.

${ }^{44}$ Aqui o autor ilustra com a seguinte assertiva, atribuída a Fances Bacon: "a verdade surge mais fácil do erro do que da confusão”. KUHN, Thomas. Estrutura das revoluções científicas, cit., p. 39.

${ }^{45}$ KUHN, Thomas. Estrutura das revoluções científicas, cit., p. 115.

${ }^{46}$ Candido Rangel Dinamarco, identifica, tal como aqui, as técnicas de aceleração como medidas que "atalham caminhos" (DINAMARCO, Cândido Rangel. Fundamentos do processo civil moderno. São Paulo: Malheiros Ed., 2001. v. 2, p. 896).
} 
aferir a existência de condições para a antecipação dos efeitos da tutela jurisdicional sem o requisito da urgência, com base na premissa de que há dois tipos de jurisdição do ponto de vista operacional, e que a jurisdição de massa permite, nas demandas repetitivas, técnica de antecipação peculiar.

Mas, antes de prosseguir, e aproveitando o tema das revoluções científicas aplicado ao mundo do processo, vale o registro de que talvez a crise mais intensa do paradigma da ordinariedade esteja na emergência dos direitos de terceira geração, sintetizados na idéia de solidariedade, que fogem ao binômio individual/coletivo e subvertem a ordem do processo convencional em seus mais diversos recantos. Aí, quem sabe, esteja se gestando uma autêntica revolução, no sentido de troca de paradigmas, pelo menos de parte do mundo do processo, o que de resto sugeriu Mauro Cappelletti, ainda na década de setenta, ao defrontar-se com o fenômeno do direito coletivo e, dentro dele, dos direitos difusos: “ $\grave{E}$ um problema di grandi proporzioni, la cui analisi approfondita, che richierebbe bem altro che una rapida relazione, può comportare na radicale revizione dell'intera cienza del diritto processuale" ${ }^{47}$.

Seja como for, a tentativa de aprimoramento do esquema da ordinariedade, explorando o quanto possível a sua capacidade de adaptação, é trabalho que está longe de se esgotar.

\subsection{Técnicas de aceleração no processo civil}

O objetivo deste tópico é fotografar, em breves linhas, o trabalho da ciência jurídica processual que, impulsionada pela crise do processo, se ocupa em construir - e reconstruir - mecanismos para despressurizar a tensão entre segurança e efetividade. Nesse sentido tenta-se estabelecer uma linha evolutiva (não cronológica, vale salientar, mas temática) do avanço transformador, que vai desde tímidas reformas das legislações processuais para suprimir fórmulas envelhecidas e renovar o ar do processo, até patamares de muita sofisticação que se movimentam em alturas significativas, como a produção de decisões provisionais sobre a lide, vocacionadas à estabilização mediante condições específicas.

\footnotetext{
${ }^{47}$ CAPPELLETTI, Mauro. Formazioni sociali e interessi di grupo davanti allá giustizia civile. Rivista di Diritto Processuale, Padova, n. 30, p. 361-402, 1975.
} 
Tratar do tema das técnicas de aceleração no interior deste estudo faz sentido, porque a proposta que aqui se pretende comprovar viável, já várias vezes referida, é também ela uma técnica de aceleração. Ademais, é possível perceber, na linha evolutiva acima indicada uma certa direção do movimento científico, que encaixa com naturalidade a técnica proposta como um próximo passo do conjunto de passos que a dogmática jurídica vem desenvolvendo, principalmente a partir da Constituição de 1988, para ficarmos nos limites de nosso País.

Como já examinado, a modernidade, com sua essência liberal, forjou um tipo de Estado, um tipo de jurisdição e um tipo específico de processo. Tal conjunto de formulações não desapareceu com a evolução dos anos, substituído por outro. Ao contrário, coexiste hoje com conquistas e transformações que foram sendo acrescentadas ao ideário liberal ${ }^{48}$. No âmbito do processo, embora a insistente pressão contra o seu esquema plenário, baseado na segurança jurídica e extremamente demorado, o processo clássico permanece como paradigma. As reformas que se vêm processando no direito brasileiro ao longo dos últimos quinze anos ${ }^{49}$ - assim como no direito processual da civil law em geral - incidem sobre o corpo desse paradigma, direta ou indiretamente.

De modo que as técnicas de aceleração foram concebidas, em um primeiro momento e com algumas ressalvas, para tornar mais rápido aquele mesmo processo, sem mexer em suas estruturas, senão para "o afastamento de fórmulas supérfluas" Alterações de procedimento, em última análise. Somente a ameaça de colapso, devido à intensa transformação do mundo, inclusive por obra da massificação, criou condições para modificações na essência do processo. Um dos vetores mais importantes neste contexto, e que tem crescido na consciência dos processualistas contemporâneos, é a idéia de que o ônus do tempo não pode mais ser debitado só e sempre à figura do autor, devendo ser distribuído de acordo com a probabilidade das alegações e dos afirmados direitos das

\footnotetext{
${ }^{48}$ Adroaldo Furtado Fabrício, estudando a presença do modelo de processo tradicional em nosso tempo, assinala: "Esse modelo sem dúvida serviu ao seu tempo. E não estamos a firmar que ele seja hoje imprestável e deva ser jogado ao lixo da História; sustentamos, sim, que ele, mesmo servindo, ainda hoje, à solução dos conflitos para os quais foi concebido e que continuam a ocorrer, é claramente insuficiente para acolher o dado novo dos contenciosos de massa (...).” FABRÍCIO, Adroaldo Furtado. As novas necessidades do processo civil e os poderes do juiz. Revista de Direito do Consumidor, São Paulo, n. 7, p. 30, jul./set. 1993.

${ }^{49}$ As reformas do processo civil brasileiro, conforme Teori Albino Zavaski, se operam em duas fases, iniciando, a primeira, em 1985, com a Lei da Ação Civil Pública (n. 7.347/85), e, a segunda, em 1994, com as sucessivas alteração ao Código de Processo Civil. Neste ponto do trabalho, em que se trata do processo ordinário, a referência o texto é à segunda fase das reformas.

${ }^{50}$ OLIVEIRA, Carlos Alberto Alvaro de. Do formalismo no processo civil. 2. ed. São Paulo: Saraiva, 2003. p. 43-44.
} 
partes. A lógica de proteger o provável em detrimento do improvável é eleita como valor relevante tanto na leitura como na operação do processo, abrindo um enorme leque de possibilidades transformadoras.

Voltando à questão da técnica, o direito processual em geral define seus esquemas de aceleração aproveitando fenômenos que emanam do litígio, do comportamento das partes, da cultura, da economia, etc. Assim o procedimento monitório converte a nãocontestação em instrumento para o ingresso direto e imediato na fase executiva. Outro exemplo é o rompimento do vínculo de trabalho, que autoriza o despejo antecipado sem o requisito da urgência nas locações decorrentes da relação de emprego (art. 59, § $1^{\text {o }}$, II, da Lei 8.245/91). Trata-se de manifestações do princípio da adaptação, ora destacadas porque este trabalho se vale do mesmo recurso, procurando encontrar no fenômeno da repetição um ponto de apoio para sustentar a antecipação de tutela sem o requisito da urgência nas demandas de massa.

\subsubsection{Introdução: sumarização formal e substancial}

É possível acelerar o processo concentrando atos ou reduzindo matérias objeto de cognição pelo juiz. Trata-se, no primeiro caso, dos procedimentos plenários rápidos ${ }^{51}$, em que se acelera sem alterar o esquema clássico, mantida a ampla possibilidade de debate e a coisa julgada como exigência prévia da execução. O exemplo sempre presente é o do procedimento sumário do processo civil brasileiro. A intenção original era concentrar em uma só audiência a contestação, a produção da prova, o debate oral e a sentença. A par da aceleração, a fórmula prestigiava a oralidade, com o fim de qualificar a decisão pelo envolvimento direto entre partes e juiz.

\footnotetext{
${ }^{51} \mathrm{~A}$ sumarização formal se expressa em vários mecanismos do CPC. Para resumir essa disseminação em um exemplo, veja-se o recente art. 555, $\S 1^{\circ}$ do CPC, em que o legislador para previnir divergências de entendimento e conseqüentes demoras na prestação jurisdicional, autoriza o relator a proceder ao que Carlos Roberto Lofego Caníbal denomina "embargagabilidade por prevenção". CANÍBAL, Carlos Roberto Lofego. Estudos de direito constitucional tributário e processo civil. Porto Alegre: Pallotti, 2006. p. 38.
} 
O procedimento sumário não alcançou os objetivos, muito em razão do excesso de demandas e do congestionamento das pautas de audiência, tornando-se eventualmente mais demorado até, que o procedimento ordinário ${ }^{52}$.

A sumarização substancial trabalha com a proibição de discutir determinadas matérias no curso do processo, que são remetidas para demanda posterior, a critério do interessado, e como tais se denominam matérias reservadas. O exemplo clássico é o das ações possessórias, em que a discussão de domínio é proibida ao réu, na forma do art. 923 do $\mathrm{CPC}^{53}$. Na mesma linha, embora com configuração algo diversa, as ações cambiárias, quando o princípio da abstração da causa jurídica subjacente exclui da discussão exceções que o devedor poderia opor à exigência do crédito.

Observa-se que a sumarização substancial não exige alteração de procedimento, necessariamente. As demandas possessórias ou cambiárias dos exemplos acima podem muito bem ser processadas pelo rito ordinário. Por outro lado, ambas as técnicas podem ser utilizadas simultaneamente. Assim, por exemplo, quando a lei prevê a decisão liminar, que é alteração relevante do procedimento ordinário, e, a par disso, reduz os temas sobre os quais o debate judicial pode acontecer, como é o caso das possessórias mais de uma vez mencionadas ${ }^{54}$.

Outra forma de acelerar é limitando certos tipos de prova. O mandado de segurança, com sua estrutura restrita à prova documental encontra, justamente nesse fechamento, o caminho para produzir jurisdição mais rapidamente.

Entre os dois modelos sucintamente apresentados, desenvolvem-se as técnicas adiante comentadas.

\subsubsection{A técnica do julgamento antecipado}

Em 1306, o Papa Clemente V, em meio a um ambiente de desorganização retardamento e alto custo do processo canônico, editou a decretal denominada Clementina

\footnotetext{
${ }^{52}$ OLIVEIRA, Carlos Alberto Alvaro de. Do formalismo no processo civil. 2. ed. São Paulo: Saraiva, 2003. p. 43-44.

${ }^{53}$ Sobre a mesma proibição no processo italiano, CARNELUTTI, Francesco. Instituciones del proceso civil. Buenos Aires: EJEA, 1960. v. 3, p. 254.

${ }^{54}$ Kazuo Watanabe relaciona várias hipóteses de utilização simultânea das técnicas. Da cognição no processo civil. 2. ed. atual. Campinas: Bookseller, 2000. p. 114-115.
} 
Saepe, instituindo profunda alteração do sistema da época. Seu significado foi muito amplo, ao trazer o juiz para o centro do processo como destinatário da prova, com poderes daí decorrentes para o indeferimento de providências inúteis e para a busca da verdade real. Mas para o fim deste estudo interessa uma específica disposição, pela qual o juiz poderia julgar o caso "tão logo lhe parecesse maduro"

Por trás do julgamento antecipado da lide do art. 330 do CPC brasileiro, especialmente o do inciso I, o que se agita é justamente a idéia de que, não obstante o procedimento seja equipado para a mais plenária das discussões, pode ocorrer que o juiz se convença, a ponto de poder sentenciar, antes de percorrer todo o ritual do procedimento. Trata-se de mecanismo de aceleração, porque antecipa a sentença, e o faz mesmo contra o eventual desejo das partes, dependendo do estado de convicção do julgador.

\subsubsection{A técnica do procedimento monitório}

A técnica monitória fundamenta-se na eventualidade de o obrigado não contestar (na legislação brasileira, não embargar) a pretensão do autor. Com base nessa probabilidade, o juiz expede mandado para o cumprimento da obrigação (de pagar ou entregar coisa, muito embora nada obste a utilização em quaisquer tipos de demandas ${ }^{56}$ ), que autoriza a execução ${ }^{57}$ na hipótese de confirmar-se a não-resistência do réu. Costuma-se classificar o gênero em procedimento monitório puro e documental. No primeiro, o mandado se expede à vista da só afirmação do autor; no segundo, exige-se que venha a documentação do afirmado direito.

O aspecto condicional que imputa o sucesso da técnica monitória à vontade do réu, em um contexto cultural de alta litigiosidade, como é o brasileiro, praticamente paralisa sua eficácia.

Mas há hipóteses de procedimento monitório em que a condicionalidade é atenuada. É o caso de certos tipos de procedimento injuncional do direito italiano, como o destinado à retomada sumária do imóvel locado, quando a impugnação oposta pelo réu não

\footnotetext{
${ }^{55}$ OLIVEIRA, Carlos Alberto Alvaro de. Do formalismo no processo civil, cit., p. 35.

${ }^{56}$ CALAMANDREI, Piero. El procedimiento monitorio, cit., p. 27.

${ }^{57}$ No direito brasileiro, a partir da Lei 11.232, de 22-12-2005, os atos de realização prática do direito reconhecido nas ações monitórias são denominados "cumprimento da sentença" (art. 1.102-C, § $3^{\circ}$ do CPC) e não pela nomenclatura genérica "execução".
} 
venha acompanhada de prova escrita (art. 665 do CPC daquele país). Também na cobrança de créditos expressos em determinados documentos (títulos cambiários ou escritura pública), o juiz pode autorizar a execução provisória, mesmo havendo impugnação do réu (art. 642 do CPC italiano). Essa possibilidade, vale acentuar, não se restringe à idéia de pregiudizio nel ritardo (periculum in mora), podendo acontecer devido à só evidência de direito que decorra da natureza do documento trazido pelo autor.

Outra característica relevante que a técnica monitória assim ajustada traduz, além da possibilidade de desfrute imediato do direito, é a oportunização de amplo direito de defesa, pois a impugnação do réu prossegue até final decisão. Compatibiliza-se, assim, dentro do mesmo processo (e não em demanda posterior, como nos exemplos de sumarização substancial antes indicados), e em uma medida de justo equilíbrio, efetividade e segurança jurídica.

O exemplo colhido no direito italiano contemporâneo remete a antigas lições de Calamandrei sobre vínculos da técnica dos procedimentos monitórios documentais (referia-se a um exemplo do direito austríaco) com o processo documental alemão:

El llamado proceso documental del derecho alemán, hoy aceptado em su
forma tradicional pela legislación germana (..) e limitado en nuestro
derecho al solo caso del proceso cambiario (...), tiene de común con el
proceso monitorio la finalidad de dar vida, con mayor celeridad que el
proceso ordinario, a un título ejecutivo (...). Esta forma de procedimiento
no encuentra justificación lógica mas que en aquellos casos en los cuales
exista en alto grado la probabilidad de que la declaración definitiva de
certeza coincida com la declaración provisional; o sea, en outra
palabras, en aquellos casos en que la naturaleza de las pruebas em las
cuales el actor apoya su demanda sea tal que haga, ya que no cierto, al
menos verosímil, el fundamiento de la demanda misma,58

Nota-se, do que foi visto, que enquanto a técnica monitória permanece restrita ao padrão de pensamento do processo clássico, ela não representa um verdadeiro avanço, porque não passa de atalho condicional entregue à sorte da vontade do demandado de impugnar, ou não, a pretensão do autor. Mas, uma vez que se admita como postulado relevante do processo o de que o juiz deve decidir quando estiver convencido, a mesma técnica assume viva funcionalidade. Afinal se, como salientado por Calamandrei, existe alta probabilidade, aferível no início da demanda, acerca de qual venha a ser a decisão

${ }^{58}$ CALAMANDREI, Piero. El procedimiento monitorio, cit., p. 34-35. 
final, nada justifica que o juiz adote a mesma conduta que deve adotar nos casos em que sua posição sobre os fatos e sobre o direito é marcada pela incerteza.

\subsubsection{A técnica da antecipação da tutela}

A técnica de decidir antecipadamente, outorgando efeitos práticos àquele que ostenta a probabilidade do direito, é muito antiga. Os interditos romanos, em alguma medida, constituem a origem remota desse sistema de prestar jurisdição. Mas o processo que se desenvolveu na Europa continental e na América Latina, quanto mais promoveu a segurança jurídica, mais se afastou da possibilidade da decisão e execução provisionais, notas que constituem a essência da antecipação de tutela. E, assim, os prejuízos suportados pelos cidadãos por causa do veto à decisão antecipada, tinham de ser enfrentados na via indenizatória tão-somente - perdas e danos.

A questão da urgência, uma especificidade no contexto mais amplo dos prejuízos decorrentes do tempo do processo, ficou confinada ao direito cautelar, com natureza só protetiva de provas ou do universo fático sobre o qual há de incidir a futura execução, não destinado a satisfazer de plano o titular do direito afirmado. Algumas antigas ações que utilizavam a técnica antecipatória permaneceram como concessão a tradições, e então foram catalogadas como procedimentos especiais no novo contexto científico do processo $^{59}$. Dentre estas, as possessórias. Por outro lado, na legislação especial, o mandado de segurança brasileiro é mais um exemplo da utilização da técnica já desde a década de cinqüenta do século passado.

Mas a necessidade da antecipação foi crescendo em um mundo cada vez mais veloz, e pressionando o ambiente fechado do direito. Durante longo período buscou-se nas possessórias, pela via da chamada posse de direitos, abertura de caminho para generalizar as tutelas antecipatórias ${ }^{60}$. Mas foi o direito cautelar que deu efetiva passagem às necessidades de antecipação de tutela satisfativa de modo a atender a necessidade social.

\footnotetext{
${ }^{59}$ Nesse sentido, SILVA, Ovídio A. Baptista da. Curso de processo civil, v. 3, p. 37.

${ }^{60}$ A utilização da estrutura das possessórias, para obviar soluções provisionais acerca de direitos não relativos a "coisas" corpóreas, remete ao período da Idade Média européia, em que a dispersão do poder (os senhores feudais, o rei e a Igreja Católica), e a conseqüente concorrência dos ordenamentos jurídicos de cada uma dessas instâncias de poder, relativizava a "certeza" jurídica no âmbito da atribuição dos direitos. Segundo José Carlos Moreira Alves, a necessidade de pacificação encontrou viva funcionalidade no esquema da posse e das ações possessórias, desenvolvida especialmente pelos canonistas, "que se preocuparam em
} 
A questão da satisfatividade sempre se confundiu em alguma medida com o direito cautelar. No CPC brasileiro, a necessidade de alimentos em caráter emergencial, não obstante a satisfatividade, era atendida pela chamada cautelar de alimentos, exemplo frisante dessa simbiose. Os pontos de intersecção, que atraíram para o universo das cautelares as tutelas satisfativas, foram a urgência e o rito processual adequado para produzir decisões rapidamente.

No Brasil, os operadores passaram a utilizar o caminho das cautelares inominadas dos artigos 798 e 799 do CPC para obter antecipatórias satisfativas em caráter genérico, devido à natureza "aberta" do instrumento, que confere ao juiz um certo poder discricionário na escolha das situações merecedoras de proteção ${ }^{61}$. Assim, a nova redação do art. 273 do CPC com a reforma de $1994^{62}$, apenas institucionalizou e conferiu um regulamento jurídico próprio às antecipatórias que, de fato, já transitavam com desenvoltura no ambiente judiciário brasileiro havia muitos anos, a ponto de se haver consagrado a locução "cautelares satisfativas" para designar o fenômeno, indicando o rito cautelar para dar curso a uma pretensão substancialmente satisfativa.

Tendo se desenvolvido no ambiente cautelar, as antecipações do art. 273 são fundamentalmente vinculadas à urgência, exceto por duas previsões excepcionais, que são as antecipatórias decorrentes do abuso ou da protelação do réu, e aquelas do direito incontroverso, adiante tratadas.

Curioso é perceber que, se as antecipatórias tivessem se desenvolvido a partir daquela outra vertente, da posse de direitos, fatalmente seguiriam uma lógica diferente,

encontrar soluçôes para atender aos fatos sociais de sua época”. E prossegue o jurista: "Bourcart, acentuando que causa admiração a extensão desmedida que o direito canônico deu à posse, a interpreta como instrumento de controle social das paixões brutais da idade média. Diz ele: 'Ela (a Igreja) não imaginou uma posse de direitos para prestar homenagem a uma distinção teórica, a uma verdade abstrata, mas para dar um meio seguro de proteger esses direitos: ela não ampliou o a teoria da posse senão para chegar a um resultado prático, à ação possessória. Nessa época, que nos transporta à idade das civilizações primitivas, a propriedade, exposta aos golpes violentos, se reconduz quase ao nível da posse: o direito não é mais nada, o fato é tudo; e, para manter ao menos um pouco de paz e estabilidade, tudo o que pode fazer um poder regular temporal ou espiritual, é exigir a conservação do fato consumado, o respeito à posse. (ALVES, José Carlos Moreira. Posse: evolução histórica. 2. ed. Rio de Janeiro: Forense, 1997. v. 1, p. 109-110). Já no século XX, embora por causas diversas, a relativização do direito e da certeza jurídica sobre a atribuição de direitos, somada à velocidade da vida, que se acentua, justificou a tentativa de estender a estrutura da ação possessória à proteção de direitos, pela enorme funcionalidade que apresenta em resolver rapidamente conflitos. Ainda sobre posse e direitos pessoais vide Adroaldo Furtado Fabrício, Comentários ao Código de Processo Civil. 8. ed. Rio de Janeiro: Forense, 2001. v. 8, t. 3, p. 387 e João Carlos Pestana de Aguiar e Silva, Apontamentos sobre a posse e os procedimentos possessórios. Revista de Processo, São Paulo, v. 40, p. 40, 1985.

${ }^{61}$ Sobre a ampla utilização das cautelares inominadas para atingir provimentos satisfativos, ver LACERDA, Galeno de. Comentários ao Código de Processo Civil. 6. ed. Rio de Janeiro: Forense, 2001. v. 8, t. 1, p. 74-92.

${ }^{62}$ Incluem-se, também, os artigos 461, $\S 3^{\circ}$, e 461-A, $\S 3^{\circ}$, do CPC. 
que não coloca a urgência em primeiro plano para autorizar a antecipação, e sim a evidência do direito, como é o esquema das possessórias desde suas origens remotas no direito romano ${ }^{63}$.

Mas o fato é que o caminho foi o das cautelares, o que limitou a utilização da técnica aos casos envolvendo a urgência. Seja como for, a institucionalização das antecipatórias, além de significar profunda alteração da essência do processo clássico, proporcionou o aprofundamento do debate de temas decisivos para o aperfeiçoamento do processo, principalmente em nível de eficiência do instrumental de execução. Assim, por exemplo, a questão da irreversibilidade, ou a da ineficiência da também clássica execução provisória para o fim da realização prática das antecipatórias; a questão dos meios executivos e da simplificação da técnica executiva, mediante a concessão ao juiz de uma maior liberdade para concretizar (ou efetivar, na linguagem da lei) as medidas antecipatórias.

Outro aspecto de excepcional relevância foi a generalização do uso desse instrumental. Embora não existam levantamentos estatísticos rigorosos, a mínima convivência do dia-a-dia dos foros comprova que é enorme o número de demandas em que a técnica da antecipação de tutela é manejada. Aliás, essa generalização vem trazendo consigo, como é natural, deformações. Reclama-se que, ao deferir a antecipatória, principalmente aquelas com índices relevantes de irreversibilidade, o juiz acaba comprometendo-se de tal maneira com a decisão que, no julgamento final, fica sem condições de julgar ao contrário do que decidira, seja porque teleguiado pelo impulso inconsciente de "confirmar-se", seja porque um eventual julgamento em sentido contrário deixaria à mostra a injustiça da antecipação de tutela. Tudo isso, acentuado, ademais, pelo contexto do excesso de processos e da jurisdição burocratizada.

Mas o fato é que não se pode mais sequer imaginar a jurisdição sem as antecipações de tutela, que se incorporaram ao sistema e prosseguem em expansão.

Outro tipo de utilização da técnica antecipatória é o previsto no art. 273, II, do CPC, a chamada tutela sancionatória ${ }^{64}$. Ou seja: aferindo o juiz que a parte pratica abuso no direito de defesa ou protela o andamento do processo, fica autorizado, mesmo sem o

\footnotetext{
${ }^{63}$ Adroaldo Furtado Fabrício verifica, de passagem, a provável relação entre o crescimento do direito urgente e "o declínio dos remédios possessórios na Europa (..), por competirem eles com os procedimentos sumários, cautelares ou não”. FABRÍCIO, Adroaldo Furtado. Comentários ao Código de Processo Civil, cit., v. 8, t. 3, p. 386.

${ }^{64}$ Sobre o tema, a obra de LOPES, Bruno Vasconcelos Carrilho. Tutela antecipada sancionatória. São Paulo: Malheiros Ed., 2006, com amplo inventário da matéria no processo brasileiro.
} 
periculum in mora, a antecipar efeitos práticos da sentença que provavelmente proferirá no futuro, desde que haja intensa verossimilhança do direito alegado ${ }^{65}$. Essa modalidade não atingiu especial destaque, seja porque guarda uma linha de intersecção com o julgamento antecipado (a protelação pode revelar, na verdade, um processo pronto para ser sentenciado), seja porque é algo difícil, na prática burocratizada do processo contemporâneo, a aferição dos desvios. Em geral, o sistema de instrução e julgamento que se foi construindo no dia-a-dia do poder judiciário brasileiro não se detém no exame aprofundado do processo ao fim da fase postulatória - momento mais apropriado a esse tipo de antecipação de tutela ${ }^{66}$-, e com isso a protelação e o abuso não são aferidos senão na sentença.

Por fim, a tutela do $\S 6^{\circ}$ do art. 273 é a que se torna viável, quando algum pedido cumulado, ou parte de pedido, é antecipado, porque não houve contestação daquele específico ponto, ou porque houve reconhecimento expresso pela parte adversa. Também aqui não há falar em urgência; o mote da antecipação é a incontrovérsia. Esse dispositivo será examinado novamente, adiante, quando se tratar do tema central do estudo, que é antecipação de tutela sem o periculum in mora nas demandas de massa.

A estrutura da técnica antecipatória, em última análise, atinge aquele objetivo tão caro ao processo contemporâneo, que é a redistribuição do ônus do tempo do processo, imputando-o total ou parcialmente ao réu.

Chegado a este ponto, é possível enxergar uma linha evolutiva (embora não cronologicamente) das técnicas de aceleração. Ao pensar-se o procedimento monitório, o que se queria era realizar de plano o direito, motivação que também justifica, embora mitigada, a idéia do julgamento antecipado. Mas só a antecipação de tutela, produzindo efeitos práticos independentemente da coisa julgada, e assumindo os riscos dessa formulação, conseguiu liberar-se da rigidez estrutural do processo clássico e, assim, transformá-lo na essência. A linha evolutiva conduz naturalmente ao próximo degrau, que é a antecipatória sem o requisito da urgência. De certa maneira, isso já se faz sentir nas

\footnotetext{
${ }^{65}$ Segundo Cândido Rangel Dinamarco, a antecipação de tutela do inciso II do art. 273 do CPC constitui instrumento de aceleração tal como aquela baseada na urgência: "num e noutro caso, está sempre manifesto $o$ intuito acelerador: Acelera-se para evitar os males concretos demonstrados ao juiz, ou acelera-se para vencer as desacelerações provocadas pela parte contrária - mas sempre a intenção é acelerar”. DINAMARCO, Cândido Rangel. Fundamentos do processo civil moderno, cit., v. 2, p. 901.

${ }^{66}$ Segundo Bruno Vasconcelos Carrilho Lopes, a antecipação sancionatória cabe não só após a contestação. Há casos que se pode aferir o manifesto propósito protelatório em atos anteriores ao ajuizamento da demanda, justificando a antecipação liminarmente. LOPES, Bruno Vasconcelos Carrilho. Tutela antecipada sancionatória, cit., p. 84.
} 
tutelas sancionatórias e nas decorrentes da incontrovérsia que, entretanto, são compreendidas dentro de limites muito estreitos, que inviabilizam a generalização dessa técnica aos casos em que a evidência do direito se instala no início, como se procurará sustentar em tópico específico logo adiante.

Vale destacar, por fim, que esse novo degrau é como um retorno ao objetivo original da técnica monitória $^{67}$, só que em um outro contexto cultural do processo.

\subsubsection{Decisões provisionais de pacificação, relativamente independentes do direito das partes (mérito) em litígio}

Um movimento emergente no processo civil contemporâneo é o da criação - ou recriação - de processos sumários em que o objetivo seja a decisão provisional de conflitos desconectada, mais ou menos, do mérito da controvérsia. Em síntese, trata-se de casos em que, por questões de natureza social de pacificação, ou por conveniência das próprias partes, o foco é a decisão mais do que o direito, ou, melhor, mais do que a justiça do caso concreto. Naturalmente, não há coisa julgada nesse tipo de provimento judicial, abrindo aos interessados a via ordinária para solucionar a lide em termos convencionais, se assim o desejarem as partes. Mas a decisão provisional é proferida sem limite temporal, e, se as partes não recorrerem à via ordinária, ela se manterá regulando sua relação indefinidamente.

São, portanto, dois os elementos de independência que se deve destacar: o elemento material, que diz respeito ao fato de o fundamento da decisão provisional conceber-se em perspectiva independente do direito de que se pretendem titulares as partes, e o elemento temporal, que desliga sua eficácia da exigência de proposição de demanda subsequiente (a ação principal).

Fritz Baur, ao deparar-se com fenômenos que denomina "estados de comunhão", como a moradia em um edifício de apartamentos, a coexistência no interior de associações, sociedades empresariais, etc, anota que tal coexistência exige laços de relação permanente

\footnotetext{
${ }^{67}$ Donaldo Armelin salienta que as antecipações de tutela sem o requisito da urgência, levam a resultados semelhantes aos decorrentes do procedimento monitório (...). O jurista refere-se, nessa passagem, às antecipações em caso de abuso de direito de contestar, ou em caso de incontrovérsia, mas a observação ajusta-se a quaisquer hipóteses de antecipação baseada em direito evidente, sem o requisito da urgência. ARMELIN, Donaldo. Tutela jurisdicional diferenciada. Revista de Processo, São Paulo, v. 17, n. 65, p. 4555, jan./mar. 1992. p. 52.
} 
entre o conjunto das pessoas. E o litígio que possa se estabelecer entre parte desses indivíduos tem potencial de atingir o funcionamento da estrutura. Nestes casos, "a medida temporária do tribunal cria um modus vivendi passageiro. Nesta situação, o de que se trata nem é tanto a preocupação em evitar um dano, mas antes, de preservar as próprias condições de funcionamento da vida em comunidade. Tenha embora um único interessado dado o impulso para a intervenção do tribunal, no primeiro plano contudo acha-se menos sua proteção jurídica individual do que, bem ao contrário, a do interesse de todos os participantes comunitários ${ }^{68}$.

A questão central do exemplo nem está na configuração da probabilidade de dano (ínsito no risco ao funcionamento do conjunto), mas no fato de que, sendo a vida comunitária o objeto maior da preocupação do juiz, ele estará decidindo não necessariamente à vista do direito das partes em conflito, ou seja, ao largo do mérito do litígio.

Este é mais ou menos o cenário do surgimento, ainda no século XVII, do référé francês: "Il 22 gennaio 1685, con un editto concernente la procedura dello Châtelet di Parigi, si attribuiva al luogotenente della città il potere di ordinare alle parti di comparire anche il giorno stesso davanti a lui per essere ascoltate e per sentirsi ordinare 'ce qu'il estimera juste'. Si notano, quindi, fin da súbito i caratteri peculiari di quest'istituto: reagire prontamente ad una situazione di urgenza, conferendo ad un'autorevole persona singola un ampio potere discrezionale, da esercitare però previa instaurazione del contraddittorio" ${ }^{69}$. A partir dessa origem, o instituto só tem feito expandir-se como constata Roger Perrot $^{70}$, utilizado para dar curso a formas variadas de jurisdição, especialmente - mas não exclusivamente - a jurisdição de urgência, inclusive aquela baseada no fumus boni iuris (que é exame do mérito em perspectiva de probabilidade). Mas importa perceber que permanecem as linhas gerais da configuração clássica, em um dos tantos tipos de référé que existem atualmente, em que o magistrado não necessita recorrer ao exame do direito (fumus boni iuris) para moldar a solução provisional.

\footnotetext{
${ }^{68}$ BAUR, Fritz. Tutela jurídica mediante medidas cautelares. Porto Alegre: Sérgio Antônio Fabris, 1985. p. 16.

${ }^{69}$ BUONCRISTIANI, Dino. Sistema dei "référé": tutela cautelare dal pregiudizo e tutela urgente senza pregiudizio. Rivista Trimestrale di Diritto e Procedura Civile, Milano, ano 60, n. 2, p. 580, jun. 2006.

${ }^{70}$ Segundo Roger Perrot, "La juridiction dês référé ha già una storia molto lunga, giacchè questa pratica è nata nel XVII secolo, nella giurisprudenza dello Châtelet di Parigi, sotto la pressione delle necessità quotidiane. Ma, cosa degna di nota, è solo da qualche anno che questa giuristizione presidenziale há avuto uma estenzione prodigiosa". PERROT, Roger. Il nuovo e futuro Codice di Procedura Civile Francese. Rivista di Diritto Processuale, Padova, v. 30, n. 2, p. 248, genn./dic. 1975.
} 
Essa configuração, somada ao fato de que se verifica em processo sumário independente do "processo principal" (que pode inclusive nem ser ajuizado) e à desnecessidade da coisa julgada, permite que a decisão seja prolatada muito rapidamente.

Na demanda plenária que se estabelecer depois, se assim o desejarem as partes (e perante outro juiz, inclusive, pois não há relação de dependência entre o processo sumário e o principal), haverá o juge du principal, em que o julgamento do mérito não fíca prejudicado pelo decreto do référé, cuja regulação fática poderá ser desfeita na execução da sentença, se por acaso ela sobrevier ${ }^{71}$.

Não é que se pretenda, na formulação atual, proibir ao juiz do référé o exame do direito das partes para decidir, produzindo assim um instituto autoritário, tal como no direito germânico medieval descrito por Galeno Lacerda linhas acima. A possibilidade do não-exame advém do objetivo, que é propiciar o afastamento eficiente e rápido do conflito, mediante juízo de equidade. Sendo assim, se a investigação do direito puder auxiliar na realização do objetivo, ela não fica vedada enquanto um recurso a mais para obviar a solução jurisdicional. Nessa linha Dino Buoncristiani assinala, tratando deste tipo de référé: "Abbiamo così una tutela urgente senza pré-giudizio, in quanto, almeno tendencialmente, il giudice può soltanto lambire il mérito della controversia” ${ }^{72}$.

No direito italiano, a instituição do chamado procedimento sommario societario, em 2005, trouxe como novidade uma certa autonomia da decisão antecipatória em relação à decisão do giudizio di mérito, na medida em que o decreto de antecipação provisional não depende, para manter sua eficácia, da propositura em tempo predeterminado da ação principal, ou, na linguagem do art. 23, n. 1, do Decreto Legislativo n. 5, que o instituiu, non perdono la loro efficacia se la causa non viene iniziata. Por outro lado, o juízo sumário permanece como que em aberto, constituindo a sede das soluções de problemas que se sucederem no conflito que originou a instituição do procedimento ${ }^{73}$.

\footnotetext{
${ }^{71} \mathrm{~A}$ descrição que se faz, aqui, corresponde às linhas gerais do modelo clássico da medida. Como referido antes, o instituto é variado e comporta diferenças, dependendo dos objetivos da jurisdição. Assim, por exemplo, nos casos em que, não havendo como solucionar o conflito mediante decreto sumário, o juiz do référé pode, a pedido da parte, solucionar o problema urgente mediante investigação do mérito, ou para obviar a tutela da evidência (rápida formação de título executivo, em vista de direito não seriamente contestável). Para uma visão integral dos diversos modelos, vide estudo recente de Dino Buoncristiani: Sistema dei "référé": tutela cautelare dal pregiudizo e tutela urgente senza pre-giudizio, cit., p. 575-600.

${ }^{72}$ BUONCRISTIANI, Dino. Sistema dei "référé": tutela cautelare dal pregiudizo e tutela urgente senza pregiudizio, cit., p. 596.

${ }^{73}$ Segundo a redação do art. 23, n. 3, do decreto legislativo n. 5: Quando il giudizio di merito non sia iniziato, la revoca e la modifica dell'ordinanza di accoglimento, esaurita l'eventuale fase di reclamo, possono essere sempre richieste al giudice che ha provveduto sull'istanza cautelare del comma 1. La revoca e la modifica
} 
É como se o legislador atentasse para o fato de que certas relações, por características próprias de sua dinâmica (o universo é do direito societário), quando judicializadas, impõem o gerenciamento do conflito de modo a propiciar que a realidade fática por trás do debate jurídico continue funcionando e, assim, evitar o mal maior do desmantelamento que a conflituosidade não resolvida pode produzir. E, se não é possível resolver com rapidez o mérito, em vista da complexidade jurídica que em geral marca essas relações, e se é desejável a manutenção da possibilidade da ampla defesa, com todo o ônus do tempo que a complexidade jurídica e a plenariedade exigem, então o legislador opta pela regulação provisional do fato.

A reflexão sobre esse tipo de medidas vem acompanhada do debate sobre a possibilidade de estabilização do que foi projetado para ser provisional e, por opção das partes em não estabelecer o juízo de mérito, acaba, na prática, tornando-se definitivo. É a constatação de Fritz Baur, ainda na década de sessenta do século passado, ao identificar situações em que "as partes contentam-se com a decisão judicial proferida no procedimento da medida cautelar e desistem do processo principal, por conseguinte, a medida cautelar substitui a sentença no processo principal, e a "regulação provisória" torna-se "definitiva",74. $\mathrm{Na}$ mesma linha, comentando o référé francês Dino Buoncristiani $^{75}$. E, mesmo no Brasil, com o projeto de alteração do Livro III do CPC, em que prevista a hipótese da estabilização da tutela antecipatória ${ }^{76}$.

Como afirmado no início, são modelos sofisticados que buscam preservar os valores da ampla defesa e da segurança jurídica (coisa julgada), elementos indissociáveis da cultura ocidental, e, ao mesmo tempo, adaptar o processo ao quadro da realidade que

sono concesse soltanto se si verificano mutamenti nelle circostanze. Possono altresì essere concesse sulla base di circostanze anteriori di cui é acquisita conoscenza successivamente al provvedimento cautelare. In tale caso, l'istante deve fornire la prova del momento in cui ne é venuto a conoscenza."

${ }^{74}$ BAUR, Fritz. Tutela jurídica mediante medidas cautelares, cit., p. 13.

${ }^{75}$ BUONCRISTIANI, Dino. Sistema dei "référé": tutela cautelare dal pregiudizo e tutela urgente senza pregiudizio, cit., p. 595.

${ }^{76} \mathrm{O}$ Instituto Brasileiro de Direito Processual elaborou anteprojeto encaminhado ao Congresso, com vista à alteração parcial do artigo 273 do CPC, e inclusão de mais quatro artigos (273-A a D) em que está prevista a estabilização da tutela antecipatória. Na "justificativa" da proposta de alteração legislativa, consta, a propósito da intenção reformista, o seguinte: "A proposta de estabilização da tutela antecipada procura, em síntese, tornar definitivo e suficiente o comando estabelecido por ocasião da decisão antecipatória. Não importa se se trata de antecipação total ou parcial. O que se pretende, por razões eminentemente pragmáticas - mas não destituídas de embasamento teórico - é deixar que as próprias partes decidam sobre a conveniência, ou não, da instauração ou do prosseguimento da demanda e sua definição em termos tradicionais, com atividades instrutórias das partes e cognição plena e exauriente do juiz, com a correspondente sentença de mérito”. Conforme GRINOVER, Ada Pellegrini. A antecipação de tutela e sua estabilização. In: MARINONI, Luiz Guilherme (Org.). Estudos de direito processual civil: homenagem ao Prof. Egas Dirceu Moniz de Aragão. São Paulo: Ed. Revista dos Tribunais, 2005. p. 231. 
demanda soluções mais rápidas para que a engrenagem da sociedade possa fluir com menos entraves. Disponibiliza-se o processo ordinário, para ser utilizado a critério das partes. Em paralelo, constrói-se um sistema de apoio para obviar os efeitos colaterais e as insuficiências do processo ordinário ${ }^{77}$.

Ao invés de enfrentar o problema da morosidade com a supressão da ampla defesa e da segurança jurídica, essas iniciativas disponibilizam aos sujeitos em conflito a opção por um sistema menos complexo e mais rápido ${ }^{78}$. Se a sociedade, premida pelo quotidiano, para usar expressão de Roger Perrot, inclinar-se por esse tipo de solução, o modelo poderá quem sabe evoluir à condição de paradigma, substituindo o modelo do processo ordinário. Atualmente, no entanto, sua função é justamente em sentido contrário, de afirmação do paradigma da ordinariedade, na medida em que acomoda as zonas em que ele se mostra ineficiente.

As considerações acima remetem à estrutura dos provimentos sumários com caráter injuncional, caracterizados pelo fato de a sentença decidir a causa sem impedir a reabertura do debate em demanda posterior de caráter exauriente para tratar de matérias que ficaram reservadas. Andrea Proto Pisani, ao conceituar esses procedimentos, assinala que sua razão de ser funda-se, no entender dele, na esperança de que as partes dêem por resolvida a contenda e não busquem a reabertura do debate em demanda posterior. Diz o jurista que os procedimentos sumários que se fundam na premissa injuncional, levam na sua estrutura o "calcolo che la fase a cognizione piena ed esauriente non si verifichi (ovvero sulla base della speranza che non sopraggiunga um successivo provvedimento a cognizione piena),

\footnotetext{
${ }^{77} \mathrm{O}$ devido processo legal e a ampla defesa, direitos constitucionais de primeira geração (CF. art. $5^{\circ}$ incisos LIV e LV) garantidores da liberdade do indivíduo e da propriedade, que estão na essência da ordinariedade, são fatores de demora do processo na medida em que propiciam amplo debate, ampla dilação probatória, acesso indiscriminado à via recursal e execução posterior à decisão definitiva (SILVA, Ovídio A. Baptista da. A "plenitude" de defesa no processo civil. In: ___. Da sentença liminar à nulidade da sentença. Rio de Janeiro: Forense, 2002. p. 107-109). Portanto a sua operacionalidade contemporânea exige mecanismos que possam conjugá-los com outro princípio de igual hierarquia, que é o da celeridade da prestação jurisdicional, ínsito no inc. LXXVIII, do art. $5^{\circ}$, da CF. Na harmonização de tais princípios, desenvolve-se a ampla estrutura de vias alternativas à ordinariedade, seja no interior do procedimento ordinário, seja em processos à parte (sumários). A intenção vetorial é garantir que a jurisdição possa realizar-se garantindo, a um só tempo, e na medida do possível, segurança e efetividade, entendida esta não apenas como jurisdição tempestiva, mas também como jurisdição de qualidade (YARSHELL, Flávio Luiz. A reforma do judiciário e a vigência de medidas liminares. Revista do Advogado, São Paulo, n. 56, p. 45, set. 1999). Vale referir, ainda, as reflexões de Luigi Paolo Comoglio acerca da justiça processual, como produto não apenas das garantias do due process of law, mas também da raggionevole duratta del processo, elementos indissociáveis do giusto processo (COMOGLIO, Luigi Paolo. Etica e tecnica del "giusto processo". Torino: G. Giappichelli, 2000. p. 13 e 85. (Biblioteca di Diritto Processuale Civile, n. 28).

${ }^{78}$ Giuseppe Tarzia refere a tendência de construção de regime de tutela jurisdicional "alternativa àquela ordinária", citando como exemplo "a tutela assegurada na França e na Bélgica, pelo référé, e na Alemanha e na Áustria, pelas denominadas disposições provisórias. TARZIA, Giuseppe. O novo processo civil de cognição na Itália. Revista da Ajuris, Porto Alegre, v. 22, n. 65, p. 84, nov. 1995.
} 
speculando in aticipo sulla mancanza o sulla infruttuosità della ulteriore fase eventuale a cognizione piena ed esauriente" 79 .

Exemplo de demandas de natureza injuncional é o das ações possessórias. Nelas, a célere regulação da realidade se dá com base nos fatos, em geral com a abstração do direito, cujo debate pode até ficar proibido, como ocorre na hipótese do art. 923 do CPC brasileiro e seu correspondente italiano, qual seja o art. 705 do Código de Processo Civil daquele País. Aliás, não é de hoje que os juristas insistem no alargamento do conceito de coisa o que na prática redundaria na posse de direitos ampliando assim a utilização do instrumento possessório ${ }^{80}$.

O breve exame das técnicas, que se desenvolveram e continuam a se desenvolver com o fim de cobrir as zonas que o processo convencional não resolve de maneira adequada, faz sentido para descrever o estágio avançado do processo contemporâneo na concepção de técnicas alternativas de tutela jurisdicional. Isso porque a proposta de antecipação de tutela sem urgência em demandas repetitivas, que é o objeto deste estudo, encaixa-se perfeitamente nessa dinâmica, tal como um desdobramento da lógica do sistema de apropriar-se das chances que a realidade oferece para qualificar a jurisdição sem o abandono das conquistas que a civilização ocidental acumulou ${ }^{81}$.

\section{O processo coletivo}

No curso da exposição até aqui delineada, várias vezes ficou evidente a íntima relação do tema das demandas repetitivas com o direito coletivo, justificando o exame particular deste segmento jurídico e das relações que mantém com o tema objeto do presente trabalho.

A linha de evolução entre o liberalismo econômico, o estado do bem-estar social e, mais tarde, os direitos de terceira geração, baseados na idéia da solidariedade, trouxe para

\footnotetext{
${ }^{79}$ PISANI, Andrea Proto. Sulla tutela giurisdizionale differenziata. Rivista di Diritto Processuale, Milano, p. 574, 1979.

${ }^{80}$ Conforme F FIGUEIRA JUNIOR, Joel Dias. Liminares nas ações possessórias. 2. ed. São Paulo: Ed. Revista dos Tribunais, 1999. p. 39-48.

${ }^{81}$ Mauro Cappelletti e Bryant Garth anotam com aguda precisão o fato da necessidade real de avanço da ciência do direito não quer dizer que o conjunto de valores do procedimento tradicional deva ser sacrificado”. CAPPELLETTI, Mauro; GARTH, Bryant. Acesso à justiça, cit., p. 164.
} 
o interior do direito a questão das massas ${ }^{82}$, reclamando um tipo de regulação jurídica diferenciada $^{83}$, origem do direito coletivo. A proteção do meio ambiente equilibrado é exemplo contundente dessa realidade, que dispensa maiores comentários, tamanha é a evidência da titularidade dispersa pelo conjunto todo das pessoas que habitam o planeta. Da mesma forma, na atividade promocional realizada por dentro do processo, que tem como objetivo a concretização dos direitos sociais: os titulares são massas de pessoas, suscitando a defesa judicial em benefício de coletividades, como, por exemplo, a reserva de cotas nas vagas em universidades públicas para segmentos da sociedade (negros, índios, estudantes da rede pública de ensino). Já do ponto de vista do modelo de produção industrial e de serviços que a modernidade produziu, o fenômeno apresenta característica peculiar, qual seja o da repetição em massa de relações jurídicas (e conflitos) individuais com características mais ou menos idênticas. E, mesmo fora do ambiente de produção industrial, é comum em sociedades de massa, que um mesmo fato ou ato tenha a potencialidade de gerar a multiplicação de lesões individuais com a conseqüente multiplicação de demandas. De modo que o impacto da massificação no mundo jurídico pode ser visualizado em duas perspectivas: a dos direitos indivisíveis pertencentes a grupos de pessoas indeterminadas, cujo exercício e defesa foge aos esquemas jurídicos convencionais, mas também a de direitos individuais que, embora suscetíveis de redução aos padrões tradicionais do direito liberal, decorrem de relações produzidas mais ou menos

\footnotetext{
${ }^{82}$ Segundo Mauro Cappelletti, “non ocorre essere sociologi di professione per riconoscere che la società (...) nella quale viviamo, è una società o civiltà, di produzione di massa, di scambi e di consumo di massa, certo anche di conflitti o conflittualità di massa (in matéria di lavoro, di rapporti fra classi socieli, fra razze, fra religione, ecc.). Ne deriva che anche le situazioni di vita, che il diritto deve regolare, sono divenute sempre più complesse, mentre a sua volta la tutela giurisdizionale - la "giustizia" - sarà invocata non più soltanto contro violozioni di carattere individuale, ma sempre più spesso anche di caratere essenzialmente collettivo, in quanto coinvolgono gruppi, classi, collettività. Si tratta, in altre parole, di "violazione di massa". CAPPELLETTI, Mauro. Formazioni sociali e interessi di grupo davanti allá giustizia civile, cit., p. 365.

${ }^{83} \mathrm{Na}$ raiz do problema coloca-se a tradicional polarização do direito em público e privado, mediante a qual o pensamento tradicional atribui ao indivíduo e ao Estado, respectivamente, as titularidades em uma e outra dessas duas instâncias. Os direitos coletivos, no entanto, escapam desse esquema, pois pertencem a todos e a nenhum ao mesmo tempo, dada a sua indivisibilidade. Não há como dividi-los para atribuir em cotas individuais aos sujeitos. Por isso, não podem ser encerrados na categoria do direito subjetivo, o que dificulta, no plano do processo, a legitimação para a sua defesa e os limites da coisa julgada da jurisdição coletiva. Por outro lado, a natureza dos direitos coletivos remete aos chamados corpos intermediários (MANCUSO, Rodolfo de Camargo. Interesses difusos: conceito e legitimação para agir, cit., p. 37), que são entidades de representação de grupos (associações, ONGs), nem privadas nem públicas - na acepção tradicional dessas locuções -, a quem se reconhece legitimidade para a defesa dos interesses coletivos. Esse reconhecimento quebra a hegemonia da premissa público/privado que está na base da formulação do direito e do processo contemporâneo. Daí a necessidade de regulação jurídica diferenciada para atender demandas peculiares que surgem no contexto das sociedades de massa. Vale anotar, por fim, como curiosidade histórica, que as raízes da percepção sobre a insuficiência da dicotomia público/privado, inclusive com o uso da locução direitos difusos, encontra-se na doutrina de Vittorio Scialoja, ao fim do século IX, ao perceber o que denominou gradações no âmbito dos direitos públicos: SCIALOJA, Vittorio. Procedimiento civil romano. Buenos Aires: EJEA, 1954. p. 475-476.
} 
em série, por isso marcadas por identidades que autorizam enxergá-las como conjunto e, pois, seus titulares como massa de pessoas ligadas por interesses comuns. Neste ponto os direitos individuais das massas ingressam direito coletivo.

No âmbito do processo, um dos sentidos do direito coletivo é racionalizar a prestação jurisdicional, impedindo a generalização de ações individuais quando possível a solução do conjunto de conflitos em uma só ação coletiva. Além da economia de tempo e dinheiro que o tratamento concentrado proporciona, há o sentido da maior eficiência no tratamento da conflituosidade social, atendendo, portanto, aos escopos sociais e políticos da jurisdição ${ }^{84}$.

É aqui que o tema toca no âmbito deste trabalho. Ou seja, na medida em que o direito coletivo, na seara dos direitos individuais homogêneos, visa a evitar repetições, o seu desejável sucesso importará, senão o fim, ao menos a redução radical das demandas repetitivas. E assim não faria sentido pensar em uma técnica de antecipação de tutela destinada a operar justamente sobre as repetições, como é aquela proposta neste estudo, que então perderia a funcionalidade.

Na verdade, examinada mais de perto a questão, percebem-se zonas não cobertas pelas ações coletivas, compostas por situações que não se amoldam aos contornos do direito individual homogêneo defensável por meio daquelas demandas, como abaixo se demonstra. Por outro lado, a sistemática do direito brasileiro, que elege a via coletiva sem obstaculizar iniciativas individuais, foi insuficiente para evitar o aumento vertiginoso de demandas individuais que poderiam ter sido solucionadas em conjunto nas ações coletivas. Esse é um fenômeno que sinaliza a necessidade de desenvolvimento de técnicas que possam minimizar os efeitos do congestionamento que assola o Judiciário brasileiro, em que o direito coletivo não tem sido suficiente, ao menos no estágio atual, para solucionar. Vista assim, a técnica proposta neste estudo, em vez de contradizer, assume um caráter de apoio à jurisdição coletiva.

\footnotetext{
${ }^{84}$ Comentando as ações coletivas no Código de Defesa do Consumidor, Kazuo Watanabe assinala: "o legislador percebeu que, nas soluções dos conflitos que nascem das relações geradas pela economia de massa, quando essencialmente de natureza coletiva, o processo deve operar também como instrumento de mediação dos conflitos sociais neles envolvidos e não apenas como instrumento de solução de lides. A estratégia tradicional de tratamento das disputas tem sido de fragmentar os conflitos de configuração essencialmente coletiva em demandas-átomo. Já a solução dos conflitos em dimensão molecular, como demandas coletivas, além de permitir o acesso mais fácil à justiça, pelo seu barateamento e quebra de barreiras sócio-culturais, evitará a sua banalização pela técnica da fragmentação e conferirá peso político mais adequado às ações destinadas à solução desses conflitos coletivos”. WATANABE, Kazuo et al. Código Brasileiro de Defesa do Consumidor comentado pelos autores do anteprojeto. Rio de Janeiro: Forense Universitária, 1991. p. 501-502.
} 
Portanto, o estudo de institutos deste novo ramo do direito é de capital importância, antes de ingressar na segunda parte do trabalho, em que se trata do seu tema central, seja estabelecendo pontos de contato, seja com o fim de aclarar a própria razão de ser da antecipação de tutela em ações individuais repetitivas.

\subsection{As três categorias dos direitos coletivos}

A doutrina reconhece a existência de um autêntico sistema de direito coletivo no Brasil $^{85}$, embora disperso em textos normativos diferentes, dentre os quais se destacam a Lei da Ação Civil Pública, a da Ação Popular e o Código do Consumidor ${ }^{86}$. É neste último corpo de normas que se encontram conceituadas as três categorias objeto da análise neste tópico. Os incisos I, II e III do art. 81 do CDC definem, respectivamente, os (a) direitos difusos, (b) direitos coletivos - stricto sensu - e (c) direitos individuais homogêneos.

São dois os vetores conceituais mais importantes que agregam a classificação, quais sejam, o caráter da indivisibilidade, ou não, do objeto do direito, e o fato de serem determináveis, ou não, os seus titulares. Assim, são difusos os direitos transindividuais (indivisíveis), cujos titulares são massas de pessoas não determináveis; os coletivos stricto sensu, também transindividuais, diferem dos anteriores porque pertencem a grupos de indivíduos determináveis, mesmo que não determinados no momento do exercício ou da defesa do direito coletivo; por fim, os individuais homogêneos são direitos divisíveis e titulados individualmente em pessoas determinadas. Assim, em aparente contradição com as referências conceituais (a indivisibilidade do objeto e a determinação dos sujeitos), esta categoria assume dimensão coletiva pelo fato de configurar disseminação de direitos em grupos significativos de pessoas, direitos esses ligados por uma origem comum.

\footnotetext{
${ }^{85}$ Teori Albino Zavaski, tratando do tema em nível de processo, menciona um "sub-sistema de processo, voltado para a tutela de uma também original espécie de direito material: a dos direitos transindividuais. ZAVASKI, Teori Albino. Processo coletivo: tutela de direitos coletivos e tutela coletiva de direitos. 2. ed. rev. e atual. São Paulo: Ed. Revista dos Tribunais, 2007. p. 37. Rodolfo de Camargo Mancuso refere o microssistema processual coletivo (MANCUSO, Rodolfo de Camargo. Jurisdição coletiva e coisa julgada: teoria geral das ações coletivas. 2. ed. São Paulo: Ed. Revista dos Tribunais, 2007. p. 17). No mesmo sentido, GIDI, Antonio. Coisa julgada e litispendência nas ações coletivas. São Paulo: Saraiva, 1995. p. 77.

${ }^{86}$ Leis $7.347 / 85,4.717 / 65$ e 8.078/90, respectivamente. Há diversas outras legislações que também tratam da defesa de direitos coletivos, tais como a Lei 7.853/89 (deficientes físicos), 8.069/90 (Estatuto da Criança e do Adolescente), 8.429/90 (Improbidade Administrativa), 8.884/94 (ordem econômica) e 10.741/03 (Estatuto do Idoso).
} 
Na lição de Teori Albino Zavaski, apenas os interesses difusos e coletivos strictu senso representam uma nova categoria do direito material, "nascida da superação, hoje indiscutível, da tradicional dicotomia entre interesse público e interesse privado. É direito que não pertence à administração pública e nem a indivíduos particularmente determinados". Já os interesses individuais homogêneos são "aqueles mesmos direitos comuns de que trata o art. 46 do $C P C(\ldots)^{87}$. Daí a distinção no título da obra do jurista entre a tutela de direitos coletivos e a tutela coletiva de direitos. A primeira, justificada e moldada a partir da natureza peculiar desses direitos, que é diversa dos direitos convencionais; a segunda, fixada mais na racionalização do tratamento da massa de conflitos que, em virtude de sua homogeneidade, permitem a abordagem como conjunto.

Dos traços conceituais sumariamente indicados, decorre uma segunda possibilidade de classificação do gênero em apenas duas categorias, quais sejam a dos direitos essencialmente coletivos ${ }^{88}$, que agrupa os difusos e os coletivos stricto sensu, e que se define na perspectiva material (direitos materialmente coletivos), e direitos cuja coletivização tem um sentido meramente instrumental ${ }^{89}$, aos quais José Carlos Barbosa Moreira imputa a sugestiva condição de "acidentalmente coletivos" ${ }^{90}$, correspondentes aos individuais homogêneos.

Merece observação, também, que um mesmo fato, ou um mesmo conjunto de fatos, pode ensejar lesões tanto coletivas quanto individuais homogêneas. Nesse sentido, o exemplo trazido por Patrícia Miranda Pizzol, sobre dano ambiental que polua um rio, gerando lesão ao direito difuso à reconstituição do ambiente agredido, mas também atingindo direito coletivo à classe dos pescadores, relativo à necessidade de ampla divulgação do retorno das condições ambientais favoráveis à pesca, e, ainda, direitos individuais homogêneos vinculados aos danos à saúde de pessoas eventualmente infectadas pela poluição ${ }^{91}$.

\footnotetext{
${ }^{87}$ ZAVASKI, Teori Albino. Processo coletivo: tutela de direitos coletivos e tutela coletiva de direitos, cit., p. 41-43.

${ }^{88}$ WATANABE, Kazuo et al. Código Brasileiro de Defesa do Consumidor comentado pelos autores do anteprojeto, cit., p. 507.

${ }^{89}$ ZAVASKI, Teori Albino. Processo coletivo: tutela de direitos coletivos e tutela coletiva de direitos, cit., p. 41-43.

${ }^{90}$ MOREIRA, José Carlos Barbosa. Tutela jurisdicional dos interesses coletivos ou difusos. In: Temas de direito processual, $3^{\text {a }}$ série. São Paulo: Saraiva, 1984. p. 196.

${ }^{91}$ PIZZOL, Patrícia Miranda. A tutela antecipada nas ações coletivas como instrumento de acesso à justiça. In: FUX, Luiz; NERY JÚNIOR, Nelson; WAMBIER, Teresa Arruda Alvim (Coords.). Processo $e$ Constituição: estudos em homenagem ao Professor José Carlos Barbosa Moreira. São Paulo: Ed. Revista dos Tribunais, 2006. p. 96-97.
} 
Nos limites deste trabalho, em cujo centro se localiza o fenômeno das repetições, frente as três categorias acima identificadas, a atenção se volta para os direitos individuais homogêneos. Isto porque a indivisibilidade que marca os direitos coletivos stricto sensu e os difusos opera de maneira que a solução jurisdicional proferida em uma única ação beneficie ipso facto a todos os prejudicados, dispensando outras demandas para a recomposição do direito violado e, assim, imunizando essa parte do direito coletivo da ocorrência de repetições. É nessa linha, portanto, que o exame prossegue.

\subsection{Direitos Individuais homogêneos em juízo: ações coletivas e ações individuais}

A tutela coletiva de direitos individuais só é possível, quando se verificarem direitos titulados em pessoas diversas ligados entre si por uma origem comum. Esse liame é o que confere homogeneidade ao conjunto e torna viável que uma única decisão possa regular as diversas relações jurídicas. Mas há um segundo aspecto importante para os fins deste trabalho, que é a necessidade de o conjunto assumir relevância que atraia o interesse social. Vale dizer: é necessário que o número de pessoas envolvidas no episódio que confere a homogeneidade seja significativo, muito embora não se possa cogitar de um número exato, a partir do qual a tutela coletiva estaria autorizada ${ }^{92}$.

Em um exercício hipotético, imagine-se a colocação no mercado de um medicamento defeituoso, com potencial capacidade de produzir danos à saúde. Imagine-se, ademais, que o fabricante, percebendo o erro, seja rápido e eficiente no recolhimento do lote ainda no distribuidor, de modo que reste comercializado o número reduzidíssimo de dez unidades que, ingeridas, causem danos a cinco pessoas, precisamente identificadas em um mesmo bairro de uma única cidade. Haverá um liame de homogeneidade nas cinco relações jurídicas individuais, mas não haverá volume suficiente para que se possa aventar seu tratamento judicial pela via do direito coletivo.

Rodolfo de Camargo Mancuso situa o debate no âmbito das condições da ação, afirmando que "o interesse de agir numa ação civil pública motivada por interesse

\footnotetext{
${ }^{92}$ Segundo Teori Zavaski, “(...) a lesão a certos direitos individuais homogêneos pode assumir tal grau de profundidade e de extensão que acaba comprometendo também interesses sociais. Realmente, há certos interesses individuais que, quando visualizados em seu conjunto, em forma coletiva e impessoal, têm a força de transcender a esfera de interesses puramente individuais e passar a representar, mais que a soma dos interesses dos respectivos titulares, verdadeiros interesses da comunidade como um todo. ZAVASKI, Teori Albino. Processo coletivo: tutela de direitos coletivos e tutela coletiva de direitos, cit., p. 57-58.
} 
individual homogêneo (v. g., cobrança indevida de mensalidade escolar) pode ser reconhecido a partir da constatação de sua relevante repercussão na sociedade civil, dado o expressivo número de pessoas envolvidas e a inviabilidade do trato processual por meio de litisconsórcio ativo facultativo, que no caso se revelaria multitudinário (CPC, parágrafo único do art. 46, acrescentado pela lei 8.952/94)”, 93.

De modo que, são dois os requisitos para a defesa coletiva de direitos individuais: o conjunto, que assume caráter socialmente valioso, e a homogeneidade, definida pela lei como a origem comum (art. 81, III, do CDC). A propósito, Kazuo Watanabe advertia, já nos primeiros tempos da vigência do CDC, que a comunhão de origem "não significa, necessariamente, uma unidade factual e temporal". E exemplificava: "as vítimas de uma publicidade enganosa veiculada por vários órgãos de imprensa e em repetidos dias, ou de um produto nocivo à saúde adquirido por diversos consumidores num largo espaço de tempo e em várias regiões têm, como causa de seus danos, fatos com homogeneidade tal que os tornam a 'origem comum' de todos eles", 94.

Prosseguindo, se a idéia de conjunto socialmente apreciável, na base da defesa coletiva de direitos individuais, é de fácil apreensão, tal não se verifica quanto ao outro requisito, da homogeneidade, que se revela com traços um pouco mais complexos.

Os direitos individuais homogêneos caracterizam-se por apresentarem questões comuns e, ao mesmo tempo, questões individuais. Assim, toda a população que ingeriu determinado produto nocivo à saúde, poderá ter direito à indenização por danos decorrentes dessa ingestão. As questões comuns são o fato, em si mesmo, da nocividade do produto, fenômeno idêntico para toda a população de consumidores, bem como a responsabilidade pela reparação - questão de direito. As questões individuais vinculam-se à verificação do dano particular de cada interessado, desde a sua existência, porque alguns indivíduos mais resistentes podem ingerir o produto sem prejuízo à saúde, até a sua extensão em cada caso particular. Nessa linha, a homogeneidade comporta graus, dependendo da maior ou menor incidência de questões comuns sobre as individuais.

No âmbito das discussões sobre critérios de rentabilidade em aplicações financeiras, como a dos chamados Planos Bresser e Collor, tudo gira em definir se era exigível em períodos específicos que os bancos corrigissem depósitos dos aplicadores com

\footnotetext{
${ }^{93}$ MANCUSO, Rodolfo de Camargo. Ação civil pública em defesa do meio ambiente, do patrimônio cultural e dos consumidores. 4. ed. São Paulo: Ed. Revista dos Tribunais, 1996. p. 58-59.

${ }^{94}$ WATANABE, Kazuo et al. Código Brasileiro de Defesa do Consumidor comentado pelos autores do anteprojeto, cit., p. 507.
} 
índices tais ou quais. A homogeneidade é bem mais intensa do que no exemplo da ingestão de produto viciado, porque a solução dos casos individuais se dá apenas na aferição do ponto em comum (o índice aplicável), sem necessidade de concluir a fixação particular das responsabilidades por questões peculiares de cada caso individual. Não que não existam diferenças individuais. Elas existem, sem dúvida, porque o consumidor "A" tinha depósitos maiores que o "B", ou depositara valores em data anterior a "C", ou fez retiradas que, de alguma forma, possam alterar sua pretensão creditícia para mais ou para menos. Contudo essas diferenças de situação não contam no âmbito da definição da responsabilidade ${ }^{95}$, ao contrário da ingestão de produto viciado, em que o caráter individual de ter havido ou não dano, é elemento formativo da responsabilidade do demandado.

Teori Zavaski desdobra a análise assinalando que entre os direitos relacionados por origem comum verifica-se um "núcleo comum" e uma "margem de heterogeneidade". E remete aos elementos das relações obrigacionais para ilustrar a asserção, quais sejam (1) identidade do credor, (2) identidade do devedor, (3) existência da obrigação (an debeatur), (4) a natureza da prestação (quid debeatur), (5) quantidade do débito (quantum debeatur). Assim, a homogeneidade se verifica, segundo o jurista, quando idênticos os elementos 2, 3 e 4; os demais - 1 e 5 -, constituem a margem de heterogeneidade ${ }^{96}$.

Definidos os requisitos para incluir os direitos individuais na pauta da defesa coletiva, a ação específica destinada a tal fim está prevista no Código de Defesa do Consumidor nos artigos 91 a 100, sob o título "Das ações Coletivas para a Defesa dos Interesses Individuais Homogêneos”.

Em termos estruturais, o legislador projetou em duas etapas sucessivas a solução judicial do conjunto de lides individuais. Em primeiro lugar, o momento da ação coletiva, limitada ao núcleo de homogeneidade. Por exemplo: é reconhecida a responsabilidade do fabricante pela reparação dos danos causados à população que consumiu o lote de remédio com defeito. Depois, sobrevém a etapa das ações individuais, que a lei denomina liquidação, em que cada qual das partes prejudicadas irá demonstrar o seu dano, o "nexo

\footnotetext{
${ }^{95} \mathrm{O}$ reconhecimento da responsabilidade se dá na fase coletiva, em que o dano necessita ser provado, ao menos por amostragem. Assim, quando se fala em definição da responsabilidade, se está destacando a individualização da responsabilidade genérica reconhecida, para cada uma das relações individuais. Esta providência é que será tanto mais simplificada quanto maior a homogeneidade dos direitos.

${ }^{96}$ ZAVASKI, Teori Albino. Processo coletivo: tutela de direitos coletivos e tutela coletiva de direitos, cit., p. 161.
} 
etiológico com o dano globalmente causado"97 e o quantum do prejuízo particularmente sofrido.

Embora o nome empregado pela Lei (liquidação - art. 97 do CDC), a segunda fase (individual) tem todos os contornos de uma verdadeira ação, justamente porque não está limitada à definição do quantum, como ocorre nas liquidações convencionais do CPC destinadas a quantificar prejuízos (art. 475-A, caput ${ }^{98}$. E uma vez superada a liquidação, opera-se a execução do crédito individual, que poderá ser realizada pessoalmente pelo interessado, ou em execução coletiva. Mas a natureza coletiva dessa execução, vale registrar, é apenas no sentido de serem justapostas várias execuções individuais em um único processo executivo. Diferente, portanto, do caráter da ação (de conhecimento) coletiva, em que não há espaço para individualizações, na medida em que trata do que é comum nas diversas relações individuais ${ }^{99}$.

Por fim, o quadro da defesa dos direitos individuais homogêneos no Brasil resguarda amplamente a iniciativa individual. Quer dizer: a propositura da demanda coletiva não obsta que os prejudicados intentem ações individuais, nem a coisa julgada coletiva prejudica o litigante individual que não participa da demanda de classe. No dizer

${ }^{97}$ GRINOVER, Ada Pellegrini et al.. Código Brasileiro de Defesa do Consumidor comentado pelos autores do anteprojeto. Rio de Janeiro: Forense Universitária, 1991. p. 556.

${ }^{98}$ Controverte-se em sede doutrinária sobre a natureza jurídica da liquidação após a reforma da Lei 11.232, de 22-12-2002, que generalizou a execução dos títulos judiciais mediante o denominado cumprimento da sentença, concebido como uma segunda fase do processo de conhecimento. Quanto à liquidação, agora regulada nos arts. 475-A a 475-H, do CPC, a reforma alterou a nomenclatura do recurso cabível contra ato decisório, que no sistema anterior era a apelação (art. 520, inc. III, do CPC, hoje revogado) e agora é o agravo (art. 475-H), o que reforça a impressão de que a natureza jurídica da liquidação deixou de ser a de ação incidental, como era no regime anterior, tornando-se simples incidente processual e não de ação (nesse sentido, CARNEIRO, Athos Gusmão. Cumprimento da sentença civil. Rio de Janeiro: Forense, 2007. p. 26-28). Não obstante, Araken de Assis arrola situações em que a liquidação constitui novidade e não apenas fase de processo anterior, como ocorre nas hipóteses dos incisos, incisos II, IV e VI do 475-N do CPC (liquidação civil de sentença penal condenatória, de sentença arbitral e de sentença estrangeira), e afirma existir aí autêntica ação de liquidação (ASSIS, Araken de. Cumprimento da sentença. Rio de Janeiro: Forense, 2006. p. 105-106). Os exemplos se ajustam ao caso das liquidações em ação coletiva, em que o autor não constituía a relação processual anteriormente. Ademais, o liquidante, aqui, além do quantum, terá de fazer a prova de sua inclusão no universo de incidência da sentença, o que reforça a natureza peculiar da liquidação nas ações coletivas que versam sobre direitos individuais homogêneos. Por isso entendemos que se trata de verdadeira ação de liquidação, cujo recurso cabível contra a decisão final é a apelação, inclusive, e não o agravo.

${ }^{99}$ Há um outro tipo de execução coletiva no âmbito dos direitos individuais homogêneos, prevista no art. 100 do CDC. Trata-se da fluid recovery do direito brasileiro (GRINOVER, Ada Pellegrini. Código Brasileiro de Defesa do Consumidor comentado pelos autores do anteprojeto, cit., p. 563). Ocorre quando, condenado o fornecedor a indenizar vítimas de produtos ou serviços defeituosos, estas não promovem - ou grande parte não promove - a execução individual. Em geral se faz necessária em casos de alta indeterminabilidade dos agentes individuais. Nestas hipóteses, os legitimados para a demanda coletiva podem executar os fornecedores com a fixação de indenizações em caráter geral, e o recolhimento do valor ao Fundo de que trata o parágrafo único do art. 100 do CDC. Esta execução não guarda relação com objeto deste trabalho, centrado em demandas repetitivas individuais. 
de Teori Zavaski, "está consagrada a liberdade do titular do direito individual de aderir ou não a processo coletivo, de submeter-se ou não ao que nele for decidido, de manter ou não, independentemente da existência ou do resultado da demanda coletiva, o seu status quo jurídico individual” ${ }^{, 100}$. O modelo difere do aplicado no direito norte-americano das class actions for damages, no qual se inspirou a ação civil coletiva brasileira. Lá, para imunizar-se contra os efeitos da coisa julgada coletiva, o interessado individual precisa manifestar expressamente sua exclusão da esfera de influência da class action.

O ponto suscita a questão da co-existência de demandas coletivas e individuais versando sobre a mesma litigiosidade, trazendo ao centro temas como a litispendência e a coisa julgada. Assim, a convivência entre os dois tipos de demandas foi arbitrado pelo legislador brasileiro nos artigos 103 e 104 do Código de Defesa do Consumidor, em que definidas as seguintes linhas gerais: (a) o reconhecimento da inexistência de litispendência, (b) a abertura das duas vias (individual e coletiva), permitindo ao agente individual: (b.1) intentar e prosseguir sua ação individual em caráter independente e desconectado do feito coletivo, sejam quais forem os seus resultados; (b.2) suspender a ação individual proposta para aguardar a sentença coletiva, aproveitando-a, se favorável, ou, se desfavorável, prosseguindo com a ação individual, (b.3) ingressar no feito coletivo como litisconsorte, podendo, neste caso, sofrer eventuais efeitos negativos da coisa julgada coletiva, contrários aos seu interesses ${ }^{101}$.

O problema do concurso das ações coletivas e individuais é decisivo para as justificativas deste trabalho, como mencionado linhas acima. Assim, justifica aprofundar alguns aspectos desse concurso na realidade brasileira, a partir dos temas da prevalência, ou não, de questões coletivas sobre as individuais, como critério definidor da existência de homogeneidade, e o da eficiência maior ou menor da ação coletiva sobre as individuais para o fim da proteção dos direitos, definindo a superioridade de um ou outro tipo de tutela no caso concreto.

Em estudo penetrante, com base no exame da realidade concreta das class actions no direito norte-americano, Ada Pellegrini Grinover conclui que a "origem comum" entre dois direitos individuais pode existir sem que exista homogeneidade. Assim, há casos em que os danos à saúde de uma população de pessoas que ingeriu determinado produto

\footnotetext{
${ }^{100}$ ZAVASKI, Teori Albino. Processo coletivo: tutela de direitos coletivos e tutela coletiva de direitos, cit., p. 176.

${ }^{101} \mathrm{Em}$ linhas gerais, o quadro reproduz lição de MANCUSO, Rodolfo de Camargo. Jurisdição coletiva e coisa julgada: teoria geral das ações coletivas, cit., p. 482.
} 
nocivo dependem mais das características individuais de cada um do que da reconhecida nocividade do produto ou, ainda, das condições em que o produto foi consumido. Nesses casos, haverá "origem comum" no fato do consumo por todos do produto nocivo, mas preponderam de tal forma os aspectos pessoais sobre os coletivos na definição da responsabilidade do fornecedor, que esses direitos perdem o seu liame de homogeneidade e se apresentam, no seu entender, como autênticos direitos heterogêneos ${ }^{102}$.

Pode parecer que se esteja apenas reproduzindo o debate sobre os graus de homogeneidade, acima discutidos. Mas não: aqui, a discussão vai bem mais longe, destacando a diferença entre direitos homogêneos e heterogêneos decorrentes de "origem comum", e não apenas de direitos mais ou menos homogêneos - mas sempre homogêneos - decorrentes, por igual, de "origem comum".

Esses contornos permitem que se definam, em termos de homogeneidade, três categorias de direitos decorrentes de origem comum: (a) direitos individuais com alto grau de homogeneidade; (b) direitos individuais com médio e baixo grau de homogeneidade e (c) direitos individuais não-homogêneos (heterogêneos) embora a origem comum.

O primeiro grupo é o espaço por excelência das ações que tratam da tutela coletiva de direitos individuais, em que elas têm como realizar o ideal da racionalização do tratamento dos conjuntos com a melhor performance. Já no segundo grupo sua capacidade de atingir tais resultados vai progressivamente enfraquecendo, o que remete ao tema da superioridade, em termos de eficiência, da tutela individual sobre a coletiva para veicular a litigiosidade presente naquela categoria. Trata-se de questão decisiva para que se reflita sobre os limites operacionais da tutela coletiva, limites a partir dos quais ela não tem como evitar o tratamento "atomizado" da litigiosidade coletiva. Ou, em outras palavras, sobre o quanto é possível tratar esses setores de litigiosidade em perspectiva "molecular".

Ada Pellegrini Grinover argumenta no sentido de que, sendo rarefeito o grau de homogeneidade, a vantagem da ação coletiva se perde:

"Um exemplo colhido de ações de classe brasileiras pode ser o de pedido de indenização consistente no ressarcimento de fumantes pelos danos provocados pelo tabaco. Nesse caso, pode-se imaginar que a sentença coletiva, mesmo se favorável, afirme simplesmente que o fumo pode ocasionar danos à saúde, condenando a ressarcir aqueles que efetivamente sofreram prejuízos, desde que comprovado o nexo causal entre suas afecções e o uso do tabaco. Toda a prova deverá ser feita no

\footnotetext{
${ }^{102}$ GRINOVER, Ada Pellegrini. Da class action for damages à ação de classe brasileira: os requisitos de admissibilidade. In: . O processo: estudos e pareceres. São Paulo: Perfil, 2005. p. 194-195.
} 
processo de liquidação e será exatamente a mesma que seria produzida em cada ação individual de conhecimento. A sentença coletiva não terá tido utilidade prática" ${ }^{103}$.

Vale dizer que, ao examinar nessa linha a relação de prevalência entre questões individuais e questões coletivas nos casos práticos, para definir o sentido da utilização da via coletiva em tema de interesses individuais homogêneos, a jurista chega às condições da ação, especificamente à impossibilidade jurídica do pedido e ao interesse de agir. Ou seja, se as questões individuais forem demasiado preponderantes sobre as coletivas, os direitos serão heterogêneos, embora a origem comum. E como o art. 81 do CDC reserva a tutela coletiva só em caso de homogeneidade, o pedido de proteção coletiva de direitos heterogêneos seria juridicamente impossível no entendimento dela. Na outra ponta, as hipóteses extremas de inutilidade da tutela coletiva em face do caráter reduzido de homogeneidade, que conduz à falta do interesse de agir pela inadequação da via coletiva $^{104}$.

Mesmo que o tema das condições da ação fosse superável, em vista da essência peculiar das tutelas coletivas, que não se submetem aos esquemas do processo convencional, e mesmo que fosse viável discordar das reduções propostas por Ada Pelegrini Grinover, o fato é que a reflexão proposta por ela comprova o quanto a ineficiência maior ou menor das ações coletivas para o tratamento de direitos individuais ligados por causa comum mantém vivas e pulsantes as ações individuais no centro do sistema da tutela coletiva, pelo menos para veicular os casos de média e rarefeita homogeneidade. E também os de alto grau de homogeneidade, quando não se verificar o outro requisito para o tratamento coletivo (interesse social), conforme exemplo formulado no início acerca do lote de medicamentos com defeito que causou prejuízo a apenas cinco consumidores.

Eis, portanto, o cenário que revela espaço bem delimitado e claro da tutela individual no interior dos conflitos de massa. Isso porque o direito coletivo não é feito para solucionar todos os casos em que a "origem comum" produz litígios individuais ligados por "origem comum".

\footnotetext{
${ }^{103}$ GRINOVER, Ada Pellegrini. Da class action for damages à ação de classe brasileira: os requisitos de admissibilidade, cit., p. 197-198.

${ }^{104}$ GRINOVER, Ada Pellegrini. Da class action for damages à ação de classe brasileira: os requisitos de admissibilidade, cit., p. 195-198.
} 
Talvez pecando por um certo excesso terminológico, pode-se dizer que, na sua própria ontologia, o direito coletivo reserva espaço à tutela individual repetitiva, o que por si só autoriza cogitar-se, como se faz neste estudo, de uma técnica a ser utilizada exatamente nesse conjunto de ações individuais, conforme explicado antes.

Mas, para além da verificação ontológica, há outras razões, mais importantes em termos de volume de causas, que se somam em termos de justificativas, analisadas no tópico que segue.

\subsection{Fragilidades do sistema de tutela coletiva de direitos individuais homogêneos}

Chegado a esta altura, para prosseguir com maior eficiência, é recomendável arrolar os pontos em que os objetivos deste trabalho se aproximam do direito coletivo. São os seguintes: (a) o estudo destina-se a demonstrar a viabilidade de antecipação de tutela sem o requisito da urgência em demandas repetitivas, justamente em razão das repetições; (b) grande parte das demandas repetitivas se encontra no âmbito dos direitos individuais homogêneos, que compõem a tutela coletiva; (c) as demandas individuais que veiculam direitos homogêneos, não obstante se apresentem como causas isoladas, peculiares, sofrem a influência e devem ser compreendidas no contexto da jurisdição coletiva, em que os escopos sociais e políticos se acentuam. Ou seja, essas demandas conservam, em certa medida, o caráter coletivo, embora veiculadas como individuais; (d) a jurisdição individual de direitos homogêneos não significa apenas uma deformação que esteja para ser superada com a evolução da cultura e das normas de direito coletivo. Há espaços em que a tutela individual é mais eficiente que a coletiva para tratar temas próprios da litigiosidade de massa (nesse sentido, temas coletivos), como ficará claro mais adiante. Vale dizer: há relação de complementariedade, no âmbito dos direitos individuais homogêneos, entre a tutela coletiva e a tutela individual.

Arroladas as aproximações, convém destacar, fechando a breve introdução, que o tema das repetições não se limita ao universo dos direitos individuais homogêneos, como adiante se faz ver, motivo por que o direito coletivo ocupa parte do trabalho, não constituindo o seu pano-de-fundo integral.

Para além dessas características permanentes, que se verificam entre o direito coletivo e o direito individual das ações repetitivas, existe outro universo de 
interpenetração que se pode aferir como fenômeno empírico, eventualmente acidental transitório, portanto -, mas que assume importância notável para refletir o momento atual da realidade judiciária brasileira. Trata-se daquelas hipóteses em que seria eficiente e justificável, na perspectiva de custos, celeridade e racionalidade, a veiculação coletiva, mas que a prática leva ao Judiciário como ações individuais, atomizando a jurisdição que poderia ser prestada em caráter "molecular" ${ }^{105}$. O interesse pelo tema, aqui, está em que essas ações individuais se apresentam com grau muito elevado de repetitividade (homogeneidade), justamente o pressuposto que, mais adiante, é explicado como motivador da antecipação da tutela sem o requisito da urgência.

Então, o objetivo, neste tópico, é examinar tal contexto para aferir o nível de transitoriedade que apresenta, se é que se trata, no todo, de uma verdadeira transitoriedade ou, ao contrário, se o fenômeno constitui realidade que possa se projetar por um período mais ou menos longo de tempo.

Prosseguindo, há um complexo de causas por trás do fenômeno.

Em primeiro lugar, o fato de que o sistema de tutela coletiva brasileiro preservou, de maneira praticamente irrestrita, a iniciativa individual em demandar direitos suscetíveis de serem solucionados em conjunto, o que importou o inevitável esvaziamento da tutela coletiva $^{106}$. Para que pudesse dar um passo à frente, adotando sistemática como a norteamericana, por exemplo, em que o titular do direito individual fica sujeito à coisa julgada coletiva, se não manifestar expressamente sua intenção em ver-se fora dela, o legislador brasileiro teria de reduzir a abrangência da tutela coletiva dos direitos homogêneos, tal como defendido por Ada Pellegrini Grinover, ao sustentar a necessidade de um exame

\footnotetext{
${ }^{105}$ Em publicação recente, Aluísio Gonçalves de Castro Mendes alude ao fenômeno como "realidade de certo modo perversa, que vem se mantendo ao longo dos últimos vinte anos: as ações coletivas não estavam obtendo pleno sucesso no sentido de serem (...) instrumento efetivo e para a solução dos problemas individuais decorrentes de origem comum. Não lograram, assim, ser um modo capaz de resolver o conflito de muitos mediante um único processo coletivo. Por conseguinte, o Poder Judiciário continuou e continua a receber centenas, milhares e milhões de demandas individuais que poderiam encontrar solução muito mais econômica mediante um processo coletivo, levando a um crescente esgotamento por parte dos órgãos judiciais, que se vêem envolvidos com um número enorme e comprometedor em termos de qualidade e celeridade dos serviços prestados. (...). MENDES, Aluísio Gonçalves de Castro Mendes. Anteprojeto de Código Brasileiro de Processos Coletivos. In: GRINOVER, Ada Pellegrini; CASTRO, Aluisio Gonçalves; WATANABE, Kazuo (Orgs.). Direito processual coletivo e o Anteprojeto do Código Brasileiro de Processos Coletivos, São Paulo: Ed. Revista dos Tribunais, 2007. p. 435.

${ }^{106}$ Aluísio de Castro Mendes, tratando da causa do cenário de fragilidade da tutela coletiva de direitos individuais expresso na nota anterior, arremata: "O motivo pode ser facilmente percebido: o sistema vigente banaliza os processos coletivos, ao permitir o surgimento e tramitação concomitantes deste com os processos individuais, que podem ser instaurados até mesmo quando já existe decisão coletiva transitada em julgado , ensejando insegurança e certa perplexidade diante da possibilidade da lide estar sendo apreciada , ao mesmo tempo, no âmbito coletivo e individual”. MENDES, Aluísio Gonçalves de Castro Mendes. Anteprojeto de Código Brasileiro de Processos Coletivos, cit., p. 435.
} 
prévio acerca da prevalência e superioridade da tutela coletiva sobre a individual. Do contrário, desconsiderando os graus de homogeneidade dos direitos e admitindo a tutela coletiva de quaisquer direitos ligados por "origem comum”, amplia-se demasiadamente o universo de incidência da tutela coletiva, podendo incluir até direitos heterogêneos ligados por causa comum, considerada a literalidade do art. 81, III, do CDC. Em um contexto assim tão amplo, não há como impor restrições às iniciativas individuais ${ }^{107} \mathrm{e}$, portanto, fica inviabilizado o fortalecimento da tutela coletiva.

O Anteprojeto de Código Brasileiro de Processos Coletivos ${ }^{108}$ procura encontrar saídas para o impasse, estabelecendo, entre os requisitos da tutela coletiva, a aferição da preponderância das questões comuns sobre as individuais e da maior utilidade da tutela coletiva no caso concreto para veicular a litigiosidade coletiva (art. 30). São requisitos que reduzem o espectro de abrangência, por um lado, mas permitem tratamento mais eficaz daquilo que, após a redução, permanece no interior do direito coletivo. Nessa linha de maior eficácia, vale anotar o tratamento da coisa julgada pelo anteprojeto, que não distingue hipóteses de deferimento ou indeferimento das pretensões, estendendo inclusive os efeitos "negativos" a indivíduos que não participaram do processo coletivo, desde que não tenham exercido o direito de exclusão ou não tenham proposto, antes da coletiva, demanda individual (art. 22, $\S 3^{\circ}$, e art. 33) ${ }^{109}$.

Mas não há perspectiva de o anteprojeto institucionalizar-se como lei em espaço reduzido de tempo, até porque a proposta envolve mexer em um dado de cultura muito arraigado, que é o da participação do indivíduo no processo como pressuposto legitimador da decisão que penetra sua esfera jurídica, principalmente a decisão restritiva.

Outro fator da realidade contemporânea que pressiona no sentido da veiculação atomizada das demandas que poderiam ser objeto de ações coletivas tem natureza

\footnotetext{
${ }^{107}$ A sutil coordenação entre o ato de reduzir o campo de incidência e o fortalecimento da tutela coletiva, possibilitando a ampliação da coisa julgada e restrições às iniciativas individuais, nem sempre é percebida. Assim nos parece a crítica de Patrícia Miranda Pizzol, ao defender que o anteprojeto de Código de Brasileiro de Processos Coletivos, nos pontos acima explicados, promove "retrocesso, prejudicando a tutela individual dos direitos homogêneos". PIZZOL, Patrícia Miranda. A tutela antecipada nas ações coletivas como instrumento de acesso à justiça, cit., p. 95.

${ }^{108} \mathrm{O}$ Anteprojeto foi concebido sob a coordenação de Ada Pelegrini Grinover e enviado pelo Instituto Brasileiro de Direito Processual ao Ministério da Justiça no final de 2005.

${ }^{109}$ Muito antes do anteprojeto, Flávio Luiz Yarshell posicionava seu entendimento nesse sentido, manifestando que o Código de Defesa do Consumidor deveria ter ido além do que foi, para que " $a$ improcedência da ação coletiva (exceto por insuficiência de elementos de prova) também atingisse os indivíduos, eis que quem tem 'adequada representação', deve tê-lo para o êxito e para o insucesso." YARSHELL, Flávio Luiz. Observações a propósito da liquidação na tutela de direitos individuais homogêneos. In: WAMBIER, Teresa Arruda Alvim (Coord.). Atualidades sobre liquidação de sentença. São Paulo: Ed. Revista dos Tribunais, 1997. p. 160.
} 
econômica e remete ao mercado da advocacia. Muitos escritórios se organizam como empresas para tratar justamente de temas massificados, construindo verdadeiras linhas de montagem que seguem a lógica do ganho em escala. O mesmo produto é replicado com alto grau de automatização e, assim, o volume dilui os custos e maximiza os lucros. Ainda nesse contexto, em alguns casos os honorários em cada unidade do conjunto são ajustados nos patamares do modelo tradicional da prestação de serviço de advocacia, em percentual sobre o êxito e/ou honorários sucumbenciais. E como os percentuais tradicionais (10\% a $20 \%$, art. $20, \S 3^{\circ}$, do $\left.\mathrm{CPC}\right)^{110}$ pressupõem o processo individual, com ampla defesa, dedicação do advogado ao longo de muito tempo, trabalhos redobrados na via recursal, etc, opera-se uma certa distorção ao transferir tais critérios percentuais para o universo da advocacia de massa, em que o trabalho é racionalizado pela repetição. Esse ganho considerável do percentual tradicional em demandas de massa constitui um atrativo de mercado para a advocacia, que direciona a litigiosidade formada por direitos individuais homogêneos às demandas individuais mais do que às coletivas.

Diga-se, entre parênteses, que a lógica não é tão-só essa. Como em tudo, há o outro lado, em que a oportunidade do negócio se encontra com o risco. Os escritórios que se dedicam à promoção de demandas de massa em geral financiam pesados custos de mão-deobra, instalações e equipamentos, assumindo o risco de eventual supressão de segmentos inteiros de litigiosidade, como ocorre, por exemplo, quando tribunais superiores consolidam a rejeição de teses jurídicas por trás de milhares de demandas idênticas. $O$ prejuízo, não só com a manutenção das estruturas destinadas à exploração daqueles segmentos ao longo do tempo, mas também com a sua desmobilização, recai todo ele na conta do empresário jurídico. E, sem dúvida, esta é uma configuração de risco muito diversa e muito mais pesada do que aquela suportada pelo advogado tradicional, que opera artesanalmente.

Fechado o parêntese, o que importa é ver que a litigiosidade dos direitos individuais homogêneos é também uma questão de mercado, o que exerce forte influência no conjunto de causas que definem o sucesso ou insucesso da tutela coletiva daqueles mesmos direitos.

Prosseguindo, outra fragilidade do sistema, que influencia na formação de ações repetitivas individuais, pode ser identificada nos casos em que a pretensão dos autores

\footnotetext{
${ }^{110}$ Os números do art. $20, \S 3^{\circ}$, do CPC não constituem as únicas referências percentuais e, por outro lado, destinam-se aos honorários de sucumbência em demandas condenatórias. A lembrança daquele dispositivo justifica-se, no entanto, porque reflete uma certa tradição acerca do custo de serviços da advocacia, inclusive de honorários contratados (não apenas sucumbenciais), valendo, ainda, para quaisquer tipos demandas (não só as condenatórias), nas quais incide sobre o valor da causa.
} 
individuais é constitutiva e não se encaixa naquilo que a doutrina indica ser a natureza jurídica da ação civil coletiva destinada aos interesses individuais homogêneos, tratada entre os artigos 91 a 100 do CDC.

Ada Pelegrini Grinover, dissertando sobre o tema, refere que a "pretensão processual do autor coletivo, na ação de que trata o presente capítulo é de natureza condenatória e de natureza condenatória será a sentença que acolher o pedido”. Tal observação consta em comentário ao art. 95 do CDC, que trata justamente da reparação de danos $^{111}$, sugerindo que os direitos individuais suscetíveis de proteção na demanda civil dos artigos 91 a 100 teriam sempre o caráter indenizatório no entendimento da doutrinadora. Paulo Henrique dos Santos Lucon e Érica Barbosa da Silva ampliam a compreensão da natureza condenatória, incluindo pretensões de "fazer ou não fazer"112. Teori Zavaski inclina-se para a natureza só declaratória da demanda coletiva em questão, haja vista o seu caráter genérico ${ }^{113}$.

Mais do que identificar o ser, no entanto, a questão da natureza jurídica importa, aqui, para identificar o "não ser". Em outras palavras: não há quem sustente a viabilidade da nota constitutiva nas ações coletivas que tratam de direito individual.

Posto isso, tomemos o exemplo de cláusula em contrato padrão de seguro-saúde autorizando a seguradora a aumentar mensalidades para além dos padrões autorizados, na hipótese de insuficiência atuarial superveniente no curso do contrato. Imagine-se, ademais, que se entenda anulável a cláusula no contexto das normas que regem o segmento econômico da saúde privada. Como se trata de impasse que atinge o grupo todo dos segurados, sua solução sinaliza a via da ação coletiva. Mas não aquela destinada pelo CDC para a proteção dos interesses individuais homogêneos (arts. 91 a 100), porque a pretensão, antes que o segurador aplique a cláusula, é no sentido da sua pura desconstituição, pois não se operou, ainda, nenhum prejuízo individual.

\footnotetext{
${ }^{111}$ GRINOVER, Ada Pellegrini. Código Brasileiro de Defesa do Consumidor comentado pelos autores do anteprojeto, cit., p. 552.

${ }^{112}$ LUCON, Paulo Henrique dos Santos; SILVA, Érica Barbosa da. Análise crítica da liquidação e execução na tutela coletiva. In: LUCON, Paulo Henrique dos Santos (Coord.). Tutela coletiva: 20 anos da Lei da Ação Civil Pública e do Fundo de Defesa de Direitos Difusos: 15 anos do Código de Defesa do Consumidor. São Paulo: Atlas, 2006. p. 164.

${ }^{113}$ ZAVASKI, Teori Albino. Processo coletivo: tutela de direitos coletivos e tutela coletiva de direitos, cit., p. 174.
} 
Como esse, há uma infinidade de exemplos, tais como o aumento de mensalidades escolares, a cobrança indevida de taxa de iluminação pública, etc, conforme indicações de Luiz Paulo da Silva Araujo Filho ${ }^{114}$.

Aparentemente, tratar-se-ia de direito coletivo stricto sensu, solucionável fora do ambiente dos direitos individuais homogêneos, o que tangenciaria o problema da falta de caráter constitutivo acima posicionado. Ocorre que a decisão em demandas essencialmente coletivas, como o são as que veiculam direitos coletivos strictu senso, não pode ser fracionada, atingindo compulsoriamente todos os segurados de maneira igualitária. Ou seja: a desconstituição vale instantaneamente para o grupo por inteiro. E, se algum dos indivíduos, compreendendo que a segurança do sistema de seguro que contratou depende do equilíbrio atuarial, pretender que a cláusula seja mantida, estará fadado, mesmo assim, à desconstituição inclusive em sua relação jurídica particular. Por isso tem-se afirmado que as pretensões constitutivas de grupos de relações jurídicas individuais são incompatíveis com a tutela coletiva ${ }^{115}$. Primeiro, porque, ao contrário dos direitos essencialmente coletivos, interesses como estes são divisíveis em tantas partes quantos forem os sujeitos individuais ${ }^{116} \mathrm{e}$, assim, não podem ser tratados em ações coletivas destinadas a resolver questões de natureza coletiva strictu senso. Em segundo lugar, porque a defesa coletiva de direitos homogêneos sempre deve acontecer em duas fases, constituindo a segunda o espaço adequado para o exercício do direito de opção do interessado individual à tutela coletiva definida em caráter genérico na primeira fase. É o que se denomina "liberdade de adesão ${ }^{117}$, inviabilizada, no caso do exemplo acima exposto, para os que concordam e vêem como necessária a cláusula de equilíbrio atuarial.

Trata-se de um grave problema a ser solucionado pela teoria do direito coletivo, considerando o número de relevantes demandas coletivas que, a valer a assertiva, estarão inviabilizadas. Parece, com efeito, que o vetor da solução estará em procurar o equacionamento mais equilibrado dos valores coletivos e individuais nestes casos, em que há uma aparente desproporcionalidade no resguardo da "liberdade de adesão".

\footnotetext{
${ }^{114}$ ARAUJO FILHO, Luiz Paulo da Silva. Sobre a distinção entre interesses coletivos e interesses individuais homogêneos. In: FUX, Luiz; NERY JÚNIOR, Nelson; WAMBIER, Teresa Arruda Alvim (Coords.). Processo e Constituição: estudos em homenagem ao Professor José Carlos Barbosa Moreira, cit., p. 81.

${ }^{115}$ "Não é cabivel, portanto, ação coletiva em defesa de direitos individuais homogêneos que tenha por objeto a obtenção de tutela de natureza constitutiva ou desconstitutiva". ZAVASKI, Teori Albino. Processo coletivo: tutela de direitos coletivos e tutela coletiva de direitos, cit., p. 188.

${ }^{116}$ Conforme ARAUJO FILHO, Luiz Paulo da Silva. Sobre a distinção entre interesses coletivos e interesses individuais homogêneos, cit., p. 82.

${ }^{117}$ ZAVASKI, Teori Albino. Processo coletivo: tutela de direitos coletivos e tutela coletiva de direitos, cit., p. 188.
} 
Nos limites deste trabalho, entretanto, o sentido maior de trazer à tona o ponto não é nem para a tomada de posição sobre ele, mas para descrevê-lo enquanto outra zona de fragilidade. E assim comprovar em caráter adicional que o direito coletivo, ao menos em seu estágio atual, não tem como mitigar extensivamente a emergência de ações repetitivas destinadas à defesa dos interesses individuais homogêneos.

Voltando-se para o ambiente interno da ação prevista nos artigos 91 a 100 do CDC, constata-se que não há chance de antecipação de tutela dos direitos individuais homogêneos na fase coletiva, pelo menos no âmbito das relativas às condenações pecuniárias $^{118}$. O limite é de simples compreensão. Dividida, como está, em duas fases, a primeira é genérica, conforme art. 96 do CDC. Só depois, no momento da liquidação, é que o pedido individual poderá ser deduzido, com o que descabe imaginar a antecipação do que é próprio da segunda fase, durante o curso da primeira. Em outras palavras, de nada adiantaria antecipar os efeitos da sentença coletiva, considerando que ela não satisfaz, por si só, a pretensão dos titulares individuais dos direitos.

Ora, a técnica da antecipação da tutela, capaz de abreviar a satisfação do provável titular do direito, é essencial para a efetividade da jurisdição, inclusive na perspectiva da melhor distribuição do custo do tempo do processo. Como tal, disseminou-se em caráter irreversível nos sistemas jurídicos contemporâneos ${ }^{119}$. Não só a antecipatória decorrente da urgência, mas todas as outras, elencadas em capítulo próprio. Assim, o corte em fases estanques, do conteúdo coletivo e do individual, se por um lado vale muito pelo quanto racionaliza o tratamento da litigiosidade, por outro, impede a técnica antecipatória, no que se revela carente de funcionalidade àqueles indivíduos que, por alguma razão, possam ver realizado seu direito de plano ${ }^{120}$.

\footnotetext{
${ }^{118}$ MANCUSO, Rodolfo de Camargo. Ação civil pública em defesa do meio ambiente, do patrimônio cultural e dos consumidores, cit., p. 96 . O autor sustenta que a antecipação de tutela para a defesa de direitos individuais homogêneos, não sendo possível em casos de direitos indenizatórios (pecuniários) é viável nas ações de obrigação de fazer e não fazer, em especial as preventivas. Teori Albino Zavaski afirma a inviabilidade integral das antecipatórias em casos de direito individual homogêneo - ZAVASKI, Teori Albino. Processo coletivo: tutela de direitos coletivos e tutela coletiva de direitos, cit., p. 191.

${ }^{119}$ Nesse sentido, com exame das antecipatórias em vários países, THEODORO JÚNIOR, Humberto. Tutela antecipada - evolução - visão comparatista - direito brasileiro e direito europeu. In: CARNEIRO, Athos Gusmão; CALMON, Petrônio (Coord.). Bases científicas para um renovado direito processual. Brasília: Instituto Brasileiro de Direito Processual, 2008. v. 1, p. 423-442.

${ }^{120}$ Flávio Luiz Yarshell afirma viável que o interessado, que não participa da demanda coletiva e não propôs demanda individual, possa pretender a antecipação de efeitos práticos, como medida antecipatória da liquidação individual que haveria de propor após o julgamento da ação coletiva. YARSHELL, Flávio Luiz. Observações a propósito da liquidação na tutela de direitos individuais homogêneos, cit., p. 157 e 165.
} 
Esta questão das antecipatórias, vale anotar, não se restringe a um exame de natureza individualista, em que se contemple apenas o prejuízo dos indivíduos que, tendo a possibilidade de fruição antecipada, ficam desprovidos dela na via coletiva. Mais que tudo, há o caráter social e político que a supressão em tela acarreta.

Com efeito, aquilo que o judiciário realiza ou deixa de realizar, como prática, nas ações de massa, pode ser pensado enquanto "informação" que ele emite aos demais agentes sociais, dentre estes em especial aos grandes agentes econômicos. Em suma, a inviabilidade da antecipatória em ações coletivas significa que os direitos individuais que estão sob o guarda-chuva daquela ação não têm como ser realizados de plano, o que o agente econômico traduz como possibilidade de retardamento da prestação respectiva, com os ganhos conseqüentes que esse retardamento possa lhe reservar.

Tudo isso parece não fazer nenhum sentido no quadro atual do direito brasileiro, que autoriza o irrestrito acesso individual, independente da demanda coletiva. Mas tal justificativa apenas demonstra o quanto a tutela individual persiste, mesmo naquelas hipóteses de intensa homogeneidade dos direitos individuais, o que só comprova o que se vem sustentando por último, qual seja, o fato de que a ampla utilização das ações individuais repetitivas prossegue na realidade brasileira, seja por razões ontológicas do direito coletivo, seja por causas transitórias, mas de baixa probabilidade de solução legislativa a curto espaço, seja por motivações culturais profundamente arraigadas.

Encerrando esta parte, vale indicar que a própria lei contém restrições a demandas coletivas em temas específicos de direito individual homogêneo, do que é exemplo o art. $1^{\circ}$, parágrafo único, da Lei $7.347 / 85$, que proíbe a tutela coletiva em casos que envolvam contribuições previdenciárias, Fundo de Garantia por Tempo de Serviço e tributos em geral, remetendo os interessados a demandas individuais repetitivas.

\section{Razoável duração do processo}

O elenco dos temas que exigem prévio desenvolvimento para autorizar o ingresso mais eficiente na segunda parte deste estudo, em que se examina o seu núcleo, fecha-se com a "razoável duração do processo", preceito hoje alçado à condição de direito fundamental pela Emenda Constitucional n. 45 de 2004. O pano de fundo da discussão, 
naturalmente, é a demora congênita na tramitação dos feitos, fenômeno que não é novo nem se limita às fronteiras de nosso País ${ }^{121}$.

\subsection{Demoras necessárias e demoras desnecessárias dos processos}

O objetivo da jurisdição é resolver o conflito com justiça, proporcionando o quanto possível a certeza jurídica, por intermédio da coisa julgada, e a realização prática do direito reconhecido em favor de seu titular. O vocábulo "justiça" pressupõe contraditório, ampla defesa e qualidade da jurisdição, valores que, somados à coisa julgada, constituem a ampla acepção da segurança jurídica. Quanto à efetividade, ela se verifica mais abertamente na realização prática do direito reconhecido ${ }^{122}$, muito embora a declaração definitiva do direito, em si mesma, independentemente de sua realização prática, já encerre o caráter da efetividade, visto que a dúvida possa constituir instabilidade jurídica em grau suficiente para configurar lesão ao titular. Essas configurações, mesmo quando verificadas em ações individuais, assumem relevância social na medida em que a solução dos conflitos, quaisquer que sejam, é um bem a ser perseguido em favor da harmonia da sociedade e, portanto, em favor de toda a população.

A utilidade da jurisdição assim concebida pode comprometer-se, no entanto - ou até ser anulada -, pelo tempo. A demora excessiva na solução do conflito, principalmente na sociedade atual, em que a vida se acelerou como nunca antes, se não esvazia o conteúdo da solução completamente, tende a minimizar o seu sentido. Muito das técnicas de aceleração tratadas em capítulos anteriores desenvolveram-se para domesticar o excesso de demora, em geral sacrificando alguns daqueles valores acima arrolados em prol de outros. Assim, na técnica da antecipação da tutela, sacrifica-se a certeza jurídica, como valor prévio da realização prática do direito, em prol do valor efetividade, quando ficar demonstrado que não é possível alcançar simultaneamente os dois valores em sua plenitude no caso concreto.

\footnotetext{
${ }^{121} \mathrm{Na}$ Itália, para citar apenas um exemplo, Ferruccio Tommaseo identifica o mesmo fenômeno como "patológica lunghezza". TOMMASEO, Ferruccio. Appunti di diritto processuale civile: nozione introduttive. 4. ed. Torino: G. Giappichelli, 2000. p. 19.

${ }^{122}$ Segundo Luís Roberto Barroso, efetividade designa "a atuação prática da norma , fazendo prevalecer, no mundo dos fatos, os interesses por ela tutelados. Ela simboliza a aproximação, tão íntima quanto possível, entre o dever ser normativo e o ser da realidade social." BARROSO, Luís Roberto. Temas de direito constitucional. 2. ed. Rio de Janeiro: Renovar, 2006. t. 1, p. 83.
} 
Mas há uma bifurcação imperiosa no caminho do discurso da demora, dividindo o tema no que se poderia classificar como demoras necessárias e demoras desnecessárias. As técnicas de aceleração de que se falou, de alguma forma, pressupõem tal classificação. Por exemplo: a operação que se realiza nos procedimentos monitórios é de afastamento de uma demora desnecessária ${ }^{123}$. Quer dizer: se o réu não pretende contestar o pedido, nada justifica, porque desnecessário, prosseguir com todo o ritual procedimental para só depois adentrar a fase de realização prática do direito pretendido pelo autor. No outro extremo as situações em que há dúvida sobre a existência do direito, exigindo o procedimento em todas as suas fases para debelar o estado de incerteza, traduzindo uma demora necessária, indispensável, recomendável até. Mas se considerarmos, também a título exemplificativo, que, nesse quadro de dúvida, o processo seja surpreendido pela ameaça de que a "demora necessária" possa levar ao perecimento do direito, terá de ser ao menos considerada a hipótese da antecipação da tutela. A demora estará justificada - é necessária -, mas mesmo assim poderá ser preciso atalhar o procedimento, mediante a ponderação dos valores em causa.

O critério de classificação das duas categorias repousa, em última análise, na questão do convencimento. Em página de singular plasticidade, Cândido Dinamarco ajusta o foco da discussão no que se pode denominar "convicção suficiente". Ou seja, sendo a certeza um ideal inalcançável pela reconstituição histórica dos fatos que se pode fazer no interior do processo, resta o julgamento pela probabilidade. E o estar em condições de julgar - o ponto de convicção - é uma confluência de fatores que determina um certo estado psicológico do julgador, que então se entende capacitado a julgar, fruto das provas produzidas ou não produzidas e do debate entre as partes, das variáveis de sua cultura pessoal e da significação do caso, em nível humano, social, econômico, etc. Sempre, afirma o jurista, haverá risco no julgamento, pois não pode haver certeza integral. Nem dos fatos e, muitas vezes, nem mesmo do direito, pela sua natureza cambiante ${ }^{124}$.

\footnotetext{
${ }^{123}$ Andrea Proto Pisani, dissertando sobre tutelas sumárias que têm em vista evitar a prática de atos desnecessários, assinala: "in primo luogo quando la tutela sommaria sia diretta ad evitare il costo del processo a cognizione piena ed esauriente, ove manchi uma seria volontà di contestazione da parte dell'obligatto. È questa la giustificazione razionale che sta alla base della técnica del procedimiento monitório”. PISANI, Andrea Proto. Sulla tutela giurisdizionale differenziata, cit., p. 568.

${ }^{124}$ Após discorrer sobre os dois sentidos que o valor certeza assume no sistema jurídico, no âmbito da definição de direitos e obrigações e no âmbito das decisões judiciais, ele se debruça sobre este segundo aspecto, sobre o qual assinala: "Agora encara-se a certeza como requisito para a realização dos atos de poder e para a determinação do seu conteúdo. No processo de conhecimento, o exagero em que a doutrina costuma incidir consiste na crença de que verdadeiramente os julgados se apóiem sempre na certeza.Essa é uma ilusão que permanece, meio por inércia dos que passam pelo assunto sem deter-se e apesar de
} 
A técnica processual ordena os passos do convencimento. É como se o legislador partisse de um standard do que sejam as necessidades, em linhas gerais, para que o processo atinja a finalidade de colocar o juiz em condições de julgar, depois de produzidas as provas e o debate jurídico em contraditório. Esse modelo, que tem como paradigma o procedimento ordinário, nem sempre se ajusta com fidelidade ao sentido último da convicção, e portanto há situações em que o "convencimento suficiente" se forma antes de concluído o percurso formalmente estabelecido pela técnica processual. Verdade que certas técnicas de aceleração procuram capturar esse elemento para construir alternativas à ordinariedade, como acontece, por exemplo, no julgamento antecipado e na antecipação da tutela motivada pela incontrovérsia (art. 273, § $6^{\circ}$, do CPC). Mas, mesmo assim, persistem situações em que há uma desconexão entre o convencimento e o ritual do processo, aquele se concluindo antes deste e ficando no aguardo para transmudar-se em decisão e realização prática do direito. São os casos de demora desnecessária, em que o procedimento é, digamos, mais longo que o necessário para realizar a função do processo.

expressivas alertas já levantados por vozes muito autorizadas./A rigor o problema da certeza não se põe somente para o juiz, nem apenas com relação às atividades jurisdicionais. Quando se pensa no processo de conhecimento, ele vem logo à mente e pensa-se então na prova, no seu desempenho quanto às questões de fato, na suas deficiências e também nas incertezas de interpretação jurídica e nos mecanismos de fixação das linhas interpretativas (...)/ Em todos os campos do exercício do poder, contudo, a exigência de certeza é somente uma ilusão, talvez uma generosa quimera. Aquilo que muitas vezes os juristas se acostumaram a interpretar como exigência de certeza para as decisões nunca passa de mera probabilidade, variando somente o grau da probabilidade exigida e, inversamente os limites toleráveis dos riscos. $E$ isso transparece no processo de conhecimento, especialmente (embora não apenas) no tocante às questões de fato (...)/ A falibilidade é inerente a todo o juízo histórico e é por isso que, no processo de conhecimento, a convicção que o juiz deve formar sobre a ocorrência dos fatos relevantes, sob pena de tê-los por não ocorridos, é apenas a sua própria 'medida psicológica da certeza': ele se convence da supremacia dos motivos convergentes e por isso afasta os divergentes, mas sempre de modo racional e assumindo calculadamente algum risco, que é inevitável. Nessa linha é que prestigiosa voz doutrinária disse: 'pensando bem, toda a prova não passa de prova de verossimilhança' (...) 'As verdades históricas não passam de probabilidades" (...). Nesse quadro em que a convicção não pode corresponder à certeza, é inevitável correr riscos, sob pena de inviabilizar os juízos. Basta que o juiz tenha atingido grau suficiente de convicção, a ponto de preferir afirmar o fato e ter por irrelevantes os motivos divergentes, Para negálos, basta a situação de dúvida (...)./Quanto ao direito, deveria haver sempre a possibilidade de ampla certeza. Jura novit curia e para todos (não só para o juiz), a ordem jurírica cria o ônus do conhecimento integral da lei. Mas, além dos conhecidos fatores que torna inaplicável essa (mal) denominada 'presunção' do conhecimento da lei (...), outros existem que inviabilizam mesmo a situação psíquica de certeza quanto ao seu conteúdo. A lei escrita dá parâmetros e limita as possíveis dúvidas, mas nem assim estas ficam definitivamente afastadas.”. DINAMARCO, Cândido Rangel. A instrumentalidade do processo. 11. ed. São Paulo: Malheiros Ed., 2003. p. 290-292. 


\subsection{Fatores exógenos e endógenos de demora}

O congestionamento do judiciário pelo excesso de demandas constitui fator autônomo de demora. O tempo do juiz para dedicar-se aos processos sob sua jurisdição é um só, delimitado pelo número de horas da jornada de trabalho. À medida que aumenta o volume de causas, permanecendo o mesmo tempo, o resultado é o congestionamento, tornando morosa a jurisdição em cada processo individualmente considerado. Uma demora exógena, porque advém de causa externa, que é o congestionamento. Mesmo o mais ajustado e célere rito procedimental não poderá dar conta dessa anomalia sistêmica.

Há, portanto, dois fatores indesejáveis que constituem o objeto do debate acerca da razoável duração dos processos. Os fatores endógenos, relativos aos casos de demora desnecessária no interior dos processos específicos, e o fator exógeno, que é o aumento da massa de demandas, aumento esse imputável a causas variadas, tais como a facilitação do acesso à justiça e as ações de massa veiculadas individualmente, sem desconsiderar outras causas mais indiretas, como a urbanização e a redução do espaço existencial das pessoas, multiplicando atritos ${ }^{125}$, ou o excesso de individualismo, ou abandono das práticas comunitárias pelos indivíduos ${ }^{126}$, etc.

Os dois fatores se interpenetram e se potencializam. A demora desnecessária, mesmo relativa à internalidade de cada processo, impede a redução da massa de ações à medida que mantém em aberto demandas que poderiam ser extintas, gerando congestionamento. Por outro lado, o congestionamento, redobrando a demora daqueles processos em que o ponto de convicção suficiente se completa antes do fim do ritual do procedimento.

\footnotetext{
${ }^{125}$ Conforme Adroaldo Furtado Fabrício, “a superpopulação reduz o espaço físico à disposição de cada indivíduo, intensificando atritos, neurotizando o convívio e favorecendo litígios: a luta pelo espaço vital vai deixando de ser simples metáfora para tornar-se a realidade do dia-a-dia”. FABRÍCIO, Adroaldo Furtado. As novas necessidades do processo civil e os poderes do juiz, cit., p. 30.

${ }^{126}$ Araken de Assis cogita de causas dessa natureza, entre outras, na raiz do aumento da litigiosidade no mundo contemporâneo: "A pessoa na sociedade pós-moderna, devidamente etiquetada (consumidor, contribuinte, cidadão e assim por diante, conforme a situação), assume a condição de litigante inveterado e intransigente (..). Não é aqui o lugar nem temos habilitação para avaliar as causas dessa tendência universal. Presumivelmente a preponderância do individualismo, o abandono das práticas comunitárias, a insuficiência dos mecanismos de repressão política, a complexidade e a diversidade sociais, contribuem em grau variável, para o quadro". ASSIS, Araken de. Duração razoável do processo e reformas da lei processual civil. In: FUX, Luiz; NERY JÚNIOR, Nelson; WAMBIER, Teresa Arruda Alvim (Coords.). Processo e Constituição: estudos em homenagem ao Professor José Carlos Barbosa Moreira, cit., p. 200.
} 


\subsection{A morosidade como tema de processo}

A constitucionalização dos direitos fundamentais suscita a questão dos mecanismos pelos quais se realizam e protegem concretamente esses direitos. Nessa linha, constitucionalizaram-se, também, princípios de direito processual que assumiram eles próprios a condição de garantias, porque de nada adianta o reconhecimento de direitos sem a previsão dos meios de sua realização e defesa, caso ameaçados ou violados.

O tempo sempre esteve na pauta do processo como contingência indissociável dele. E quanto mais o valor justiça progrediu como vetor da jurisdição, mais exigiu tempo para realizar-se pelo interior do processo, a ponto de transformá-lo, na sugestiva metáfora de Carnelutti, em inimigo a ser combatido sem trégua ${ }^{127}$.

Com o aumento acentuado da litigiosidade e do congestionamento do Judiciário, a demora toca os limites das garantias constitucionais, passando a ser tratada como problema de efetividade da jurisdição, o que confere à questão do tempo do processo status constitucional. No Brasil, bem antes do atual inciso LXXVIII do art. $5^{\circ}$ da Constituição Federal, o inc. XXXV daquele mesmo artigo dava sustentação ao discurso doutrinário sobre a necessária tempestividade como garantia constitucional (até hoje válido, a propósito) no sentido de que, ao prever o acesso à justiça implicitamente previa, para além do fato de que "todos podem ir a juízo (...), que todos têm direito à adequada tutela jurisdicional, ou melhor, 'a tutela jurisdicional efetiva, adequada e tempestiva" 128.

Em outros países, o mesmo fenômeno vem suscitando através dos anos a edição de textos normativos para debelar a questão do tempo. Na Europa, a Convenção para Salvaguarda dos Direitos do Homem e das Liberdades Fundamentais, de 1950, prevê no seu art. $6^{\circ}, 1, \mathrm{o}$ direito de todos a que suas causas sejam examinadas em tempo razoável. $\mathrm{O}$

\footnotetext{
${ }^{127}$ CARNELUTTI, Francesco. Diritto e processo. Napoli: Morano, 1958. p. 354.

${ }^{128}$ CRUZ E TUCCI, José Rogério Tempo e processo. São Paulo: Ed. Revista dos Tribunais, 1997. p. 66. No mesmo sentido, Kazuo Watanabe: "O princípio da inafastabilidade do controle jurisdicional inscrito no inc. XXXV do art. $5^{\circ}$ da Constituição Federal, não assegura apenas o acesso formal aos órgãos judiciários, mas, sim, o acesso à Justiça que propicie a efetiva e tempestiva proteção contra qualquer forma de denegação de justiça e também o acesso à ordem jurídica justa”. WATANABE, Kazuo. A tutela antecipatória e tutela específica das obrigações de fazer e não fazer. Revista da Ajuris, Porto Alegre, v. 23, n. 66, p. 160-161, mar. 1996. Confirma ainda que o inc. XXXV do art. $5^{\circ}$ da CF consagra o princípio da efetividade, Carlos Alberto Alvaro de Oliveira, "pois não é suficiente tão-somente abrir a porta de entrada do Poder Judiciário, mas prestar jurisdição tanto quanto possível eficiente, efetiva e justa, mediante um processo sem dilações temporais ou formalismos excessivos": OLIVEIRA, Carlos Alberto Alvaro de. Formas de tutela jurisdicional no chamado processo de conhecimento. Revista da Ajuris, Porto Alegre, v. 32, n. 100, p. 65, dez. 2005.
} 
dispositivo tem sido utilizado pela Corte Européia dos Direitos do Homem para penalizar Estados-Membros por dilações indevidas na prestação jurisdicional ${ }^{129}$. Na Constituição Espanhola de 1978, cuja síntese é também a da proibição de “dilações indevidas” (art. 24.2), fixou-se a idéia de que se trata de direito fundamental dos cidadãos, de que decorre direito subjetivo indenizatório ${ }^{130}$. Portugal, na Constituição de 1976, localizou o tema no art. $20^{\circ}$, sob o título geral do "acesso ao direito e tutela jurisdicional efectiva", relacionando expressamente a questão do tempo com a efetividade, e prevendo, no item 4 daquele artigo, que "todos têm direito a que uma causa em que intervenham seja objeto de decisão em tempo razoável (...)”. Por fim, a reforma de 1999, incluiu na Constituição italiana a ragionevole duratta do processo, na forma da lei (art. 111). E a lei em causa sobreveio em 2001 (n. 89), detalhando o direito à reparação e à publicidade, em caso de prestação jurisdicional fora do tempo adequado.

Diga-se, por fim, que a Convenção Interamericana sobre Direitos Humanos, aprovada pelo Pacto de San José de Costa Rica, em 1969, de que foi signatário o Brasil, prevê no seu art. $8^{\circ}$ o direito à jurisdição em prazo razoável. E, como o preceito foi inserido no ordenamento jurídico brasileiro em 1992, mediante o Decreto 678 do Poder Executivo, também por esta via a doutrina sustentava a dimensão constitucional da tutela tempestiva, considerando que os direitos previstos em convenções internacionais de que for signatário o Brasil estão automaticamente incorporados ao elenco do $\operatorname{art} .5^{\circ}$ da Constituição, por força do que dispõe o seu $\S 2^{\circ}$ ( “Os direitos e garantias expressos nesta Constituição não excluem outros decorrentes do regime e dos princípios por ela adotados, ou dos tratados internacionais em que a República do Brasil seja parte).

As expressões que se multiplicam quando se trata do tema (demora, morosidade, celeridade, aceleração, dilações indevidas, razoável duração do processo, tempestividade da jurisdição) têm significados semânticos que nem sempre convergem e, isoladas, não revelam a idéia que as reúne em um sentido único. Assim, se tornarmos a locução razoável duração do processo descontextualizada, não estaremos necessariamente falando em aceleração, pois, dependendo do contexto, ela pode encerrar idéia diametralmente oposta. Basta pensar em um quadro de aceleração indevida, demasiada, que comprometa profundamente a qualidade da decisão judicial. Nessa hipótese, a reação em prol da

\footnotetext{
${ }^{129}$ CRUZ E TUCCI, José Rogério Tempo e processo, cit., p. 69-75.

${ }^{130}$ CRUZ E TUCCI, José Rogério Tempo e processo, cit., p. 76.
} 
paciência e do espaço para meditação adequada (da qualidade da justiça, em suma) poderá ser feita justamente pela via da razoável duração do processo.

Do ponto de vista semântico, parece mais plena de significados a referência a dilações indevidas. Diga-se que foi justamente para realçar o sentido último que essa locução pode encerrar que o título do item 4.1, supra, posicionou as "demoras necessárias" e as "demoras desnecessárias", de alguma maneira direcionando o foco para estas últimas. Mas “dilações indevidas" não diz tudo sobre o mal da morosidade da jurisdição, porque fala mais diretamente da internalidade dos processos. Quer dizer: não abrange com a mesma eficiência de significação os fatores exógenos de morosidade, tratados no item 4.2, acima. Naquela perspectiva, a dilação ocorrerá devido a uma circunstância não imputável ao juiz ou ao Judiciário, mas a um agente externo, ao volume de demandas, ao fenômeno da excessiva litigiosidade, a uma contingência da realidade, em outras palavras.

Nesse quadro de complexidades, a idéia-síntese é a de que a razoável duração do processo, no momento atual, veio para o centro do debate para expressar a necessidade de providências, internas e externas aos processos individuais, providências inclusive em prol da alteração de paradigmas da cultura dos operadores do direito, como também providências jurídicas, no âmbito da dogmática, a fim de combater a demora e propiciar que a jurisdição possa gerar efeitos práticos em menor lapso de tempo. Esse é o contexto no qual se utilizam indistintamente as expressões acima arroladas ao longo do trabalho.

Retornando à letra do inciso LXXVIII do art. $5^{\circ}$ da Constituição, após o exame do conjunto legislativo referido acima, pode-se afirmar que ele não representou mais que a formalização de algo que já existia implícito no sistema, e que é fruto de um processo mais amplo de evolução jurídica em várias partes do mundo ocidental.

Mas há pelo menos mais uma raiz de compreensão da razoável duração do processo, que se revela no interior do devido processo legal. E porque oferece uma amplitude valiosa de compreensão conjuntural, merece exame destacado em tópico específico. 


\subsection{Devido processo legal e tempestividade da jurisdição}

$\mathrm{O}$ art. $5^{\circ}$, inciso LIV, da Constituição Federal prevê que o devido processo legal haverá de ser observado como um prius a qualquer ato legítimo de invasão no âmbito da liberdade ou dos bens do indivíduo ("ninguém será privado da liberdade ou de seus bens sem devido processo legal”). "Bens", aqui, em sentido amplo, incluindo o patrimônio material e imaterial ${ }^{131}$. Essa garantia fundamental, associada ao inciso seguinte (LV) do mesmo art. $5^{\circ}$ da Constituição, que trata do contraditório e da ampla defesa, fixa o caráter mais de salvaguarda, de defesa do indivíduo contra o Estado. Esse, aliás, é o traço histórico do instituto, ícone da cultura liberal, previsto expressamente na $5^{\mathrm{a}}$ e $14^{\mathrm{a}}$ emendas da Constituição dos Estados Unidos ${ }^{132}$, fonte inspiradora do direito brasileiro no ponto. Nessa linha é que Carlos Alberto Alvaro de Oliveira anota que "o aspecto mais essencial do devido processo legal é o de assegurar o contraditório e a ampla defesa"133, e que Ovídio Baptista da Silva, ainda nos primeiros tempos de vigência da Constituição de 1988, registrava o receio de que o somatório puro e simples das duas garantias (due process of law e ampla defesa) promovesse a supervalorização da plenariedade e, pois, da demora, em prejuízo da efetividade do processo $^{134}$.

Mas o desenvolvimento do constitucionalismo norte-americano havia construído configuração alternativa ao devido processo legal. Em paralelo à concepção processual, em que ele significa apenas a garantia formal de um processo previamente regulado pelo direito, sobreveio a concepção material ou substantiva, na qual o sentido é informar o processo do ideal de justiça, ou seja, da pauta de direitos fundamentais a que ele, o processo, enquanto garantia constitucional, destina-se a proteger. Trata-se do devido processo substancial (substantive due process of law), que a Constituição italiana, na

\footnotetext{
${ }^{131}$ OLIVEIRA, Carlos Alberto Alvaro de. Do formalismo no processo civil, cit., p. 85.

${ }^{132} \mathrm{~A}$ origem mais remota do devido processo legal está no direito inglês, especificamente a Magna Carta de 1215, que restringiu o poder do Soberano. Em seu item 39, dispunha, conforme tradução de J. J. Gomes Canotilho "Nenhum homem livre será detido ou sujeito à prisão, ou privado de seus bens, ou colocado fora da lei ou exilado, ou de qualquer modo molestado e nós não procederemos ou mandaremos proceder contra ele, senão mediante um julgamento regular pelos seus pares, de harmonia com a lei do país" CANOTILHO, J. J. Gomes. Direito constitucional e teoria da Constituição. Coimbra: Almedina, 1998. p. 448.

${ }^{133}$ OLIVEIRA, Carlos Alberto Alvaro de. Do formalismo no processo civil, cit., p. 86.

${ }^{134}$ SILVA, Ovídio A. Baptista da. A "plenitude" de defesa no processo civil, cit., p. 109.
} 
abertura do seu art. 111, denomina giusto processo $^{135}$, e que J. J. Gomes Canotilho sintetiza na seguinte passagem:

"A protecção alargada de um processo equitativo significará também que o controlo dos tribunais relativamente ao carácter 'justo' ou 'equitativo' do processo se estenderá, segundo as condições particulares de cada caso, às dimensões materiais e processuais do processo no seu conjunto. $O$ parâmetro de controlo será, sob o ponto de vista intrínseco, o catálogo dos direitos, liberdades e garantias constitucionalmente consagrados e os direitos de natureza análoga, constantes de leis ou convenções internacionais $(. . .)^{136}$

Segundo Roberto del Claro, a pretensão do constituinte brasileiro foi introduzir a cláusula do devido processo na Constituição de 1988 no seu sentido substancial ${ }^{137}$, o que de resto acabou consagrado na exegese que se formou ao longo dos vinte anos de vigência da Carta de 1988, valendo citar, por todos, a seguinte passagem da doutrina de Cândido Dinamarco, justamente nesse sentido:

"A expressa garantia do due process of law, contida no inc. LIV do art. $5^{\circ}$ da Constituição Federal, tem o significado sistemático de fechar o círculo das garantias e exigências constitucionais relativas ao processo, numa fórmula sintética destinada a afirmar a indispensabilidade de todas e reafirmar a necessidade de cada uma. Esse enunciado explícito vale ainda como norma de encerramento portadora de outras exigências não tipificadas em fórmulas mas igualmente associadas à idéia democrática que deve prevalecer na ordem processual $\left(\operatorname{art} .5^{\circ}, \S 2^{\circ}\right)$ "138

Com base nesse conjunto de idéias, é que alguns doutrinadores passaram a visualizar, na cláusula do devido processo legal, não apenas a presença do valor segurança jurídica, ínsito na ampla defesa e no contraditório, para os quais o devido processo empresta passagem em primeira mão, mas igualmente a do valor efetividade, reforçando-a

\footnotetext{
${ }^{135}$ Nesse sentido COMOGLIO, Luigi Paolo. Etica e tecnica del "giusto processo", cit., p. 13, e FAZZALARI, Elio, Il giusto processo e i "procedimenti speciali" civili. Rivista Trimestrale di Diritto e Procedura Civile, Milano, ano 57, p. 2-3, mar. 2003.

${ }^{136}$ CANOTILHO, J. J. Gomes. Direito constitucional e teoria da Constituição, cit., p. 451.

${ }^{137}$ DEL CLARO, Roberto. Devido processo substancial? In: MARINONI, Luiz Guilherme (Org.). Estudos de direito processual civil: homenagem ao Prof. Egas Dirceu Moniz de Aragão. São Paulo: Ed. Revista dos Tribunais, 2005. p. 207. Vale anotar que Del Claro é contrário à doutrina do devido processo substancial na sua origem norte-americana, na medida em que enxerga na sua operação prática pela Suprema Corte dos Estados Unidos, em geral, a usurpação pelo judiciário das atribuições do legislativo. E sobre o Brasil, ele refere que o fato de a Constituição prever expressamente os direitos fundamentais em outros dispositivos, dispensaria o devido processo em caráter substancial para alcançar a sua proteção (p. 211). Sobre esta última afirmação do citado autor, cabe referir que o direito à efetividade da jurisdição não está expresso em nenhum dispositivo constitucional.

${ }^{138}$ DINAMARCO, Cândido Rangel. Instituições de direito processual civil. São Paulo: Malheiros Ed., 2005. v. 1 , p. 264.
} 
enquanto garantia constitucional, que em princípio fora indicada como valor implícito na fórmula ampla do acesso à justiça (do art. $5^{\circ}$, inciso XXXV, da Constituição), conforme explicado acima. E tudo isso diz respeito também à tempestividade da tutela jurisdicional, pela sua indissociável ligação com a idéia de efetividade ${ }^{139}$.

A vigência da Emenda 45, que inseriu expressamente a tempestividade da tutela como direito fundamental no rol do art. $5^{\circ}$ da Constituição, sugere que seria, hoje, desnecessária sua conexão com o devido processo legal para afirmá-la como "valor" de primeira grandeza no plano constitucional. Dispensável, portanto, a uma primeira vista, todo o discurso desenvolvido nos últimos parágrafos. Ocorre que o aspecto da "justiça" que informa a doutrina do substantive due process of law, revelada, segundo os doutrinadores norte-americanos, na perspectiva da racionalidade ${ }^{140}$, é decisivo para que se possa sustentar, adiante, o postulado da "justiça procedimental" a ser aplicado aos casos em que se verificam o que se denominou alhures "demoras desnecessárias". E para esse fim, a abrangência mais ampla da tempestividade, compreendida pela via do devido processo, é mais eficiente que o recurso à letra do inciso LXXVIII, que não revela em si mesma o fecundo processo de elaboração do princípio da celeridade até sua expressa inclusão no texto constitucional.

\subsection{A tempestividade da jurisdição no contexto da eficácia das normas constitucionais}

Chegado a este ponto, questão que se coloca é a da eficácia da disposição constitucional que determina a razoável duração do processo. O tema, na realidade, é bem mais amplo, deitando raízes na crise do constitucionalismo na passagem entre as constituições liberais, centradas em garantias de proteção do indivíduo contra o Estado e, portanto, operando negativamente, e as constituições sociais, na parte em que impõem ao Poder a realização positiva de princípios. Em suma, trata-se da dificuldade em transformar

\footnotetext{
${ }^{139}$ Nesse sentido, CRUZ E TUCCI, José Rogério. Garantia da prestação jurisdicional sem dilações indevidas, como corolário do devido processo legal, cit., p. 76.

${ }^{140}$ Conforme OLIVEIRA, Carlos Alberto Alvaro de. Do formalismo no processo civil, cit., p. 87.
} 
princípios em direitos subjetivos ${ }^{141}$. De modo que se justifica o tratamento apartado da questão da eficácia do inciso LXXVIII do art. $5^{\circ}$ da Constituição.

Nem todas as normas constitucionais têm suficiente normatividade para realizarem a plenitude de seus comandos mediante incidência direta. Essa constatação está à base de um longo debate sobre o problema da aplicabilidade das normas constitucionais. Na verdade, a origem mais remota do constitucionalismo europeu emprestava às constituições um caráter fundamentalmente político de exortação ao legislador e ao administrador, pelo que suas normativas não existiam propriamente para incidir e regular juridicamente situações concretas específicas $^{142}$. Só mais tarde, já no século XX, sob o influxo da fase social das constituições é que a natureza jurídica dos corpos constitucionais passa ao primeiro plano na Europa, e o problema da sua aplicabilidade jurisdicional assume relevância decisiva.

Diversamente, os Estados Unidos desde o início compreenderam sua constituição como corpo de normas a regular situações em perspectiva jurídica ${ }^{143}$. E foi na linha do constitucionalismo norte-americano que Rui Barbosa concebeu a classificação que norteou o direito constitucional brasileiro até meados do século $\mathrm{XX}^{144}$, distinguindo as normas entre não-auto-executáveis e auto-executáveis. Aquelas, assim denominadas por causa de seu conteúdo indeterminado, dependente de integração pelo trabalho do legislador ordinário; estas, com conteúdo normativo completo e, portanto, independentes de atividade integradora da legislação infraconstitucional. Mas não quer isso dizer que o Brasil, na prática, tenha-se adiantado no tempo em relação à Europa. Ao contrário, foi só após a vigência da Carta de 1988 que o tema da aplicabilidade constitucional em perspectiva

\footnotetext{
${ }^{141}$ Conforme Paulo Bonavides, nas constituições sociais direitos "concernentes às relações de produção, ao trabalho, à educação, à cultura, à previdência, representavam uma estupenda novidade, um campo por inteiro distinto desconhecido do Direito Constitucional clássico. Mas dificilmente as redações que os inseriam se prestavam a uma redução jurídica fácil, de modo a fazê-los ingressar no corpo da Constituição dotados já de aplicabilidade direta e imediata. Segundo o jurista, esse novo tipo de normas, denominadas "programáticas" problematizou em níveis inimagináveis o conteúdo jurídico das constituições. Trata-se do momento genético da segunda fase do constitucionalismo, o da programaticidade das constituições, segundo ele "até agora não ultrapassada" BONAVIDES, Paulo. Curso de direito constitucional, cit., p. 207.

${ }^{142}$ Conforme BONAVIDES, Paulo. Curso de direito constitucional, cit., p. 202, e Luís Roberto BARROSO. Segundo este último, "Uma das grandes mudanças de paradigma ocorridas durante o século XX foi a atribuição à norma constitucional do status de norma jurídica. Superou-se, assim, o modelo que vigorou na Europa até meados do século passado, no qual a Constituição era vista como um documento essencialmente político, um convite à atuação dos poderes públicos. A concretização de suas propostas ficava invariavelmente condicionada à liberdade de conformação do legislador ou à discricionariedade do administrador. Ao judiciário não se reconhecia qualquer papel relevante na realização do conteúdo da Constituição”. BARROSO, Luís Roberto. Temas de direito constitucional, cit., t. 3, p. 68.

${ }^{143}$ Conforme BARROSO, Luís Roberto. Temas de direito constitucional, cit., t. 3, p. 64.

${ }^{144}$ SARLET, Ingo Wolfgang. A eficácia dos direitos fundamentais, cit., p. 240-241.
} 
jurídica tomou espaço de real importância prática, uma vez que a própria Constituição assumiu o centro do sistema jurídico com a redemocratização do país ${ }^{145}$.

Prosseguindo, o advento do welfare state, na medida em que atribui ao Estado atuação positiva para a realização da igualdade material dos cidadãos, traz para o interior das constituições um novo tipo de normas, denominadas pela consagrada locução até hoje empregada de normas programáticas. O seu reconhecimento no Brasil veio pela doutrina de Pontes de Miranda, que as acrescentou à classificação de Rui Barbosa. Segundo ele, as normas programáticas são dirigidas aos administradores, legisladores e juízes, para orientar suas funções ${ }^{146}$, sendo vedado a estes legislar ou atuar contrariamente aos programas nelas estabelecidos.

Com o passar do tempo e a consolidação progressiva do constitucionalismo de matriz social, o tema da eficácia foi também sendo especializado em perspectivas classificatórias mais precisas, valendo citar, como síntese, o critério de José Afonso da SILVA, que distingue as normas em tela entre (a) normas de eficácia plena e aplicabilidade imediata, (b) normas de eficácia contida e aplicação imediata, mas passíveis de restrição e (c) normas de eficácia limitada ou reduzida, estas últimas subdivididas em (c.1) definidoras de princípio institutivo, (c.2) definidoras de princípio programático ${ }^{147}$.

Mais recentemente, Ingo Wolfgang Sarlet, após sumariar as principais classificações da doutrina brasileira e posicionar o fato de que as classificações têm função prioritariamente didática e operacional sem, contudo, esgotarem "todas as manifestações possíveis da eficácia e aplicabilidade ${ }^{148}$, propõe critério distintivo mais amplo, partindo de duas premissas que afirma consensuais na doutrina. Primeiro, a de que não existem

\footnotetext{
${ }^{145}$ Normas de matriz social existem em todas as constituições brasileiras a partir de 1934 (SARLET, Ingo Wolfgang. A eficácia dos direitos fundamentais, cit., p. 241), mas até 1988 as constituições não ocupavam, substancialmente, por razões históricas e políticas, o centro do ordenamento jurídico, o que se viabiliza em larga escala a partir da redemocratização do País, processo que tem na Constituição de 1988 uma de suas culminâncias mais significativas. É a razão por que se posicionou o tema como contemporâneo ao da edição da Carta ora em vigor.

${ }^{146}$ Afirma Pontes de Miranda, que "uma das classificações mais importantes, sobretudo quando se atende ao caráter social das Constituições, é a que distingue as regras jurídicas em regras bastantes em si mesmas, regras não-bastantes em si mesmas e programáticas". Na verdade, as duas primeiras correspondem às categorias identificadas por Rui Barbosa, apenas com denominação alterada. Quanto às programáticas, o jurista explica tratar-se de regras em que o legislador, "em vez de edictar norma de aplicação concreta, apenas traça linhas diretoras,pelas quais se hão de orientar os poderes públicos. A legislação, a execução e a própria justiça ficam sujeitas a esses ditames, que são como programas dados à sua função" MIRANDA, Francisco Cavalcanti Pontes de. Comentários à Constituição de 1946. 3. ed. Rio de Janeiro: Borsoi, 1960. t. 1, p. 110-111.

${ }^{147}$ SILVA, José Afonso da. Aplicabilidade das normas constitucionais. 2. ed. São Paulo: Ed. Revista dos Tribunais, 1982. p.79-85.

${ }^{148}$ SARLET, Ingo Wolfgang. A eficácia dos direitos fundamentais, cit., p. 251-252.
} 
normas constitucionais desprovidas totalmente eficácia; em segundo lugar, a de que existem normas constitucionais dependentes de atividade legislativa posterior para realizarem os seus principais efeitos. Dessa polarização, ele revela o caráter de "graduação de carga eficacial" "149, distinguindo então o gênero em (a) normas constitucionais de alta densidade normativa, aptas a gerar seus efeitos sem a mediação do legislador ordinário e, (b) normas constitucionais de baixa densidade normativa, por isso dependentes da atividade ulterior para realizarem seus efeitos principais ${ }^{150}$.

Para os fins deste trabalho, que não tem por objetivo direto a revisão das teorias acerca da eficácia das normas constitucionais, é bastante a utilização do núcleo de consenso acima explicado, ou seja, o fato de que sempre haverá algum tipo de eficácia. Por outro lado, tendo em vista que a norma aqui debatida (inc. LXXVIII do art. $5^{\circ}$ ) pode ser qualificada como princípio constitucional, que se expressa no caso concreto mediante ponderação de valores e bens (conforme item 4.6, abaixo), também é relevante destacar a idéia de graduação da eficácia, que então poderá verificar-se maior ou menor a partir do caso concreto. Ou seja, o princípio da tempestividade não fica preso a uma configuração de limites de eficácia pré-determinada, que só será suscetível de identificação precisa no caso concreto. Por fim, o último elemento que faz sentido apropriar das classificações acima é o das normas programáticas, haja vista sua larga utilização.

Feito isso, para concluir com mais clareza, vale transcrever o dispositivo constitucional sob análise, que tem a seguinte redação:

Art. $5^{\circ}$. (...)

LXXVIII. A todos, no âmbito judicial e administrativo, são assegurados a razoável duração do processo e os meios que garantam a celeridade de sua tramitação.

\footnotetext{
149 “Em que pesem as distinções entre as concepções sumariamente apresentadas, e até mesmo a diversidade de critérios nas quais se baseiam, constata-se, no mínimo, dois aspectos (...) a respeito dos quais todas as formulações guardam identidade. Com efeito, todos os autores citados partem da premissa de que inexiste norma constitucional completamente desprovida de eficácia, sendo possível sustentar-se, em última análise, uma graduação de carga eficacial das normas constitucionais. Todas as propostas reconhecem, contudo, que determinadas normas da Constituição em virtude da ausência de normatividade suficiente, não estão em condições de gerar, de forma imediata, seus principais efeitos, dependendo, para tanto, de uma atuação integradora por parte do legislador ordinário, razão pela qual também costumam ser denominadas de normas de eficácia limitada ou reduzida". A eficácia dos direitos fundamentais, cit., p. 251-252.

${ }^{150}$ SARLET, Ingo Wolfgang. A eficácia dos direitos fundamentais, cit., p. 250.
} 
Estabelecida como foi a existência de causas exógenas e endógenas de retardamento dos processos (item 4.2, supra), o primeiro alvo da norma em questão é o congestionamento da justiça (causas exógenas). Para tanto, a própria Emenda 45 iniciou a previsão dos meios para promover a celeridade conjuntural do sistema, com medidas de restrição e de racionalização, tanto dirigidas ao universo dos recursos nos tribunais superiores (efeito vinculante das decisões do STF - art. 102, § $2^{\circ}$-, repercussão geral como requisito ao recurso extraordinário - art. 102, § $3^{\circ}$ - e súmula vinculante - art. 103-A), como à administração geral da justiça (proibição de férias coletivas nos tribunais - art. 93, XII -, possibilidade de prática de atos processuais ordinatórios pelo staff do juiz - art. 93, XIV).

Portanto, na perspectiva das causas exógenas de retardamento, o inciso LXXVIII do art. $5^{\circ}$ contém um inegável conteúdo programático, dirigido ao legislador e à administração da justiça, incitando-os a prosseguir o trabalho iniciado pela própria Emenda Constitucional, mediante a construção de outros meios para a aceleração conjuntural e o aperfeiçoamento dos já existentes, na busca do máximo de eficiência e celeridade ${ }^{151}$. Programática, porque define uma intenção, um fim que a Constituição elegeu para ser perseguido.

Já do ponto de vista da vítima da demora, não se pode excluir a idéia da incidência direta do preceito constitucional para o fim de conferir direito subjetivo contra o Estado à reparação dos danos que tenha experimentado. Essa é a realidade atual na Europa, que muito bem a jurisprudência brasileira poderá adotar, considerando a natureza aberta do tipo constitucional, que reclama a complementação do direito pelo aplicador.

Relativamente às causas endógenas de retardamento, a norma também apresenta um inegável caráter programático, na medida em que estimula o legislador a alterar processo em busca de aperfeiçoá-lo em sua internalidade, como é exemplo a instituição do art. 285-A do CPC. Mas também é viável pensar na incidência direta do preceito em processos cuja morosidade atinja padrões excepcionais. Flávio Luiz Yarshell, ao tempo da tramitação do Projeto da Emenda Constitucional 45, destacava essa possibilidade, argumentando com a hipótese em que, reconhecida por decisão judicial a extrapolação do

\footnotetext{
${ }^{151}$ José Afonso da Silva (Curso de direito constitucional positivo. 31. ed. São Paulo: Malheiros Ed., 2008. p. 433), aduz, embora de passagem, o dever de a Administração do Tribunal a que pertencer magistrado que, por desídia, provoque retardamento excepcional, "tomar as providências para o cumprimento das garantias asseguradas no inciso em apreço”. Uma vez viável um tal tipo de providência, ela encerra hipótese de incidência direta da norma constitucional.
} 
tempo razoável de duração de um processo, o juiz poderá, quem sabe, adotar providências de agilização tais como “(i) antecipar tutela em favor do titular, (ii) liberar execução, subtraindo o efeito suspensivo do recurso pendente de julgamento (..), adotar as providências necessárias para que, se não terminado o processo, seja dado à parte um resultado em tempo razoável ${ }^{\prime 152}$. Em suma, acelerar como providência de reequilíbrio do tempo do processo em vista da demora desproporcional.

Não obstante todas essas possibilidades, o objetivo do presente estudo é menos amplo no âmbito da eficácia das normas constitucionais, pois o que mais importa evidenciar, aqui, é um aspecto presente em todas as categorias daquelas normas. Trata-se do efeito de releitura do direito ordinário que uma Constituição impõe ao entrar em vigor. No específico caso ora tratado - a tempestividade da jurisdição - o primeiro plano operativo da releitura é arredar fórmulas que se revelem contrapostas à idéia de celeridade $^{153}$, desde que não haja algum outro suporte constitucional de igual categoria a justificar sua manutenção. Em segundo lugar, como vetor hermenêutico, a vigência do dispositivo opera para permitir a ampliação de limites a técnicas já existentes no sistema que possam, ajustadas pela orientação do novo valor constitucional, atingir o objetivo genérico da aceleração.

Trata-se da filtragem constitucional de que fala Luís Roberto Barroso nos seguintes termos:

"A partir da passagem da Constituição para o centro, passou ela a funcionar como a lente, o filtro através do qual se deve olhar para o direito de uma maneira geral. Este fenômeno é referido por alguns autores como filtragem constitucional: a Constituição condiciona a interpretação de todas as normas do sistema jurídico." ${ }^{154}$

\footnotetext{
${ }^{152}$ YARSHELL, Flávio Luiz. A reforma do judiciário e a vigência de medidas liminares, cit., p. 32.

${ }^{153}$ Luigi Paolo Comoglio, tratando da garantia do "giusto processo" expresso na Constituição Italiana, que guarda simetria com o devido processo substancial da Constituição Brasiléia, abaixo tratado, explica a eficácia daquele dispositivo, no mesmo sentido a filtragem constitucional acima referido: "La nuova garanzia dovrebe, quindi, consentire um ampio scrutinio della legittimità di molti istituti del processo vigente i quali - nel disciplinare le forme, le cadenze, i tempi e gli eventi anomali del giudizio -, rendono possibili gli eventuali 'abusi' del processo, ad opera di uma parte in danno dell'altra, nonchè um irrazionale allungamento della sua durata ed aggravamento dei costi (individuali e sociale).”.

${ }^{154}$ BARROSO, Luís Roberto. Temas de direito constitucional, cit., t. 3, p. 509. No mesmo sentido, Celso Antônio Bandeira de Mello: “(...) a regra constitucional pode ainda limitar-se tão-somente a (...) expressar em sua dicção apenas uma finalidade a ser cumprida obrigatoriamente pelo Poder Público, sem, entretanto, apontar os meios a serem adotados para atingi-lo, isto é, sem indicar as condutas específicas que satisfariam o bem jurídico consagrado na regra. E arremata: "o Judiciário, ao decidir sobre qualquer relação jurídica, , haverá de ter presentes estes vetores constitucionais como fator de inteligência e interpretação da relação jurídica sub judice” (MELLO, Celso Antônio Bandeira de. Eficácia das normas constitucionais sobre justiça social. Revista de Direito Público, São Paulo, n. 57/58, p. 243, 1981).
} 
E prossegue o jurista, assinalando que, em qualquer interpretação que se faça, se stará, na verdade, interpretando a Constituição e aplicando seus preceitos, seja diretamente, “quando alguma pretensão se funda em dispositivo do próprio texto constitucional", seja indiretamente, para, no ato de interpretar a norma infraconstitucional, atribuir a ela o sentido e o alcance que melhor realizarem os "fins e valores constitucionais" 155 .

Converge com essa ordem de idéias a proposição de Flávio Luiz Yarshell a respeito da constitucionalização da razoável duração do processo:

"No plano da 'processualística ordinária', há mecanismos dirigidos ao escopo de acelerar a prestação jurisdicional. A antecipação de tutela, o processo monitório, os títulos executivos extrajudiciais, a execução provisória (podendo chegar a resultados definitivos), são exemplos disso.

“(...) é preciso fazer desses instrumentos situados na 'processualística ordinária' - porque são eles que estão ao alcance do jurisdicionado e são eles que apresentam concreção necessária para tornar a promessa uma realidade - os meios para dar efetividade ao direito previsto pela Constituição ${ }^{156}$.

Tais assertivas podem ser contempladas em dupla perspectiva pela ótica da eficácia das normas constitucionais: (i) como hipótese de incidência direta do inciso LXXVIII do art. $5^{\circ}$, se a aplicação dos mecanismos da 'processualística ordinária' for realizada sem nenhuma adaptação sistemática (por exemplo: constatada a demora excepcional, antecipase a tutela tão-só por causa da demora, independentemente dos requisitos específicos do art. 273 do CPC); (ii) pela reavaliação daqueles mecanismos a partir da filtragem constitucional, para ampliá-los até onde a releitura orientada pelo novo valor permita avançar.

O que se pretende, logo adiante, adotando esta última posição, é a releitura do $\S 6^{\circ}$, do art. 273 do CPC, que prevê a antecipação de tutela em casos de incontrovérsia, para revelar a viabilidade de sua aplicação também as hipóteses em que a repetição configurar a evidência do direito do autor na fase inicial do litígio.

\footnotetext{
${ }^{155}$ BARROSO, Luís Roberto. Temas de direito constitucional, cit., t. 3, p. 510.

${ }^{156}$ YARSHELL, Flávio Luiz. A reforma do judiciário e a vigência de medidas liminares, cit., p. 32.
} 


\subsection{Conflito entre segurança jurídica e tempestividade: o problema da harmonização de princípios constitucionais}

A idéia de tempestividade, além do conteúdo aberto que não oferece contornos precisos para nortear o intérprete, convive em permanente tensão com as exigências da segurança jurídica ${ }^{157}$, que reclama tempo para ser observada no processo. Desde sempre foi assim, o que se compreende partindo do pressuposto mais elementar de que o juiz, sendo terceiro em relação à lide, precisa conhecê-la antes de julgar e realizar o direito, um conhecimento marcado por valores construídos ao longo de séculos de civilização que demanda meditação, e conseqüente demora, para realizar-se adequadamente.

Essa tensão entre dois princípios de idêntica hierarquia constitucional traduzindo antinomia, reclama o indispensável posicionamento sobre o tema haja vista sua íntima relação com o objeto deste estudo.

Para fazê-lo, a primeira questão que se coloca é saber se a segurança jurídica e a tempestividade podem ser posicionadas na categoria de princípios constitucionais, e qual o valor dessa catalogação.

Tomado o gênero norma jurídica, é possível distinguir duas categorias, que são as regras e os princípios ${ }^{158}$. Aquelas, fechadas, mais claras, feitas para operar em termos de "tudo ou nada", com fronteiras precisas e em geral trabalhando com códigos binários (válido/inválido; permitido/proibido), como ocorre, por exemplo, no art. 508 do CPC, que limita em 15 dias o prazo para a propositura dos recursos que enumera. De modo que as normas inseridas na categoria das regras jurídicas trazem em si as premissas de sua aplicação e a respectiva conseqüência jurídica previamente determinadas, fazendo que se apresentem tendencialmente unívocas, ou seja, sem margem dispersiva que ofereça opções

\footnotetext{
${ }^{157}$ Carlos Alberto Alvaro de Oliveira, tratando da efetividade da qual a razoável duração do processo constitui aspecto decisivo na realidade contemporânea, anota o permanente estado de tensão que em geral marca a relação entre os dois princípios: “interessante é que ambos se encontram em permanente conflito, numa relação proporcional, pois quanto maior a efetividade menor a segurança, e vice-versa. OLIVEIRA, Carlos Alberto Alvaro de. Formas de tutela jurisdicional no chamado processo de conhecimento, cit., p. 65.

${ }^{158}$ Essa terminologia e organização de gênero e espécies é consagrada entre os estudiosos do direito constitucional contemporâneo, como refere BONAVIDES, Paulo. Curso de direito constitucional, cit., p. 248. Atribui-se a criação a Robert Alexy, jurista alemão que assim posiciona o tema no contexto de suas teorizações sobre o constitucionalismo: "La distinción entre reglas e princípios constituye la base de mi argumento en favor de um constitucionalismo moderado. Tanto las reglas como los princípios pueden ser concebidos como normas. Si esto es así, entonces se trata de uma distinción dentro de la classe de las normas.”. ALEXY, Robert. El concepto y la validez del derecho. Tradução de Jorge M. Seña. Barcelona: Gedisa Editorial, 1994. p. 162.
} 
de escolha ao intérprete ${ }^{159}$. Já os princípios, segunda categoria das normas jurídicas, definem-se justamente por não apresentarem soluções unívocas a problemas abstratamente considerados, senão a possibilidade de escolha pelo intérprete entre mais de uma solução possível. São normas que se revelam, em graus mais ou menos acentuados, ambíguas e difusas $^{160}$.

Essa diferenciação tem um sentido funcional, a partir da constatação de que os níveis de estabilidade social são variáveis ao longo da história. Quanto mais estável a sociedade, maior consenso haverá sobre o direito no seu interior, permitindo clareza na normatização jurídica, que então se faz fundamentalmente por intermédio das regras, mais adequadas à formulação do direito em ambientes com tal conformação. Mas, quando a sociedade se movimenta sem esse nível de consenso, instabilizando-se, a clareza do direito progressivamente se esvanece, porque o direito mesmo envolve-se na instabilidade social. É necessário ressalvar, entretanto, que esse quadro não representa necessariamente uma configuração negativa, de crise social no sentido de perda, tendo em vista que o progresso, a superação de valores arcaicos, a intensificação das liberdades, o crescimento da economia, etc, enquanto transformações positivas, podem ser fatores de instabilidade social, sobretudo quando acontecem muito rapidamente. Seja como for, esses momentos de transformação geram tensões no direito, pelo menos em certos setores eventualmente mais expostos às especificidades da turbulência social. Então, o equilíbrio jurídico depende de formulações com maior flexibilidade, o que é próprio dos princípios e não das regras. Isso para que o direito possa oferecer-se como instrumento de coesão, um amortecedor dos excessos que propicie à sociedade condições de progredir nas suas crises.

Eduardo Faria, embora utilizando nomenclatura ligeiramente diversa (denomina "norma", como categoria, o que acima indicamos como "regra"), descreve a razão de ser dos princípios de modo bastante preciso, que justifica a transcrição:

"A finalidade dos princípios é obter adesão, catalisar o apoio para o sistema jurídico. Estruturalmente, os princípios têm uma certa dificuldade no fato de o legislador quase sempre utilizar a norma, que é clara, precisa, que trabalha acima de tudo com o código binário: ou pode ou não pode, ou é legal ou ilegal. O legislador trabalha com a

\footnotetext{
${ }^{159}$ DWORKIN, Ronald. Levando os direitos a sério. São Paulo: Martins Fontes, 2002. p. 39-40.

${ }^{160}$ Para J. J. Gomes Canotilho, as regras "são normas que, verificados determinados pressupostos, exigem, permitem ou proíbem algo em termos definitivos, sem qualquer exceção (...); princípios são normas que exigem a realização de algo, na melhor forma possível, de acordo com as possibilidades fáticas e jurídicas. Os princípios não proíbem, permitem ou exigem algo em termos de "tudo ou nada"; impõem a optimização de um direito ou de um bem jurídico, tendo em conta a 'reserva do possível', fática ou jurídica. CANOTILHO, J. J. Gomes. Direito constitucional e teoria da Constituição, cit., p. 1123.
} 
norma para regular situações já cristalizadas, estabilizadas. Situações nas quais existe algum tipo de consenso, algumas expectativas consolidadas, alguma jurisprudência formada (...). No entanto, quando existem situações instáveis, não cristalizadas, momentos de profundo dinamismo social, não conseguimos operar com as normas, ou seja, a norma para poder funcionar como uma técnica de legislação depende de um contexto estável. Quando surge um contexto razoavelmente instável, e o legislador tem a obrigação ou o desafio de regulá-lo, retoricamente, não haveria outra alternativa senão recorrer aos princípios. Por isso, quando analisamos o direito brasileiro dos últimos anos, verificamos que ele é uma combinatória de princípios e normas (...)"

As configurações até aqui desenvolvidas respondem às indagações que ficaram implícitas no primeiro parágrafo deste tópico, sobre a natureza da segurança jurídica e da tempestividade enquanto garantias constitucionais. São princípios, inegavelmente; abertos, fluidos, feitos para mediar situações que não têm como ser solucionadas na perspectiva do "tudo ou nada". Por outro lado, fica também respondida a segunda indagação lá posicionada, sobre o valor em trabalhar o tema neste estudo. Isso porque a catalogação da segurança jurídica e da tempestividade como princípios constitucionais autoriza o acesso ao método de operação dos princípios, cuja "abertura" permite alguma liberdade de interpretação no contexto do problema que se apresenta ao intérprete, em busca da melhor hipótese de realização dos objetivos constitucionais. Isto, aplicado à idéia de "injustiça procedimental" referida linhas acima, propiciará, a seu tempo, revelar que a melhor interpretação do CPC, à luz da regra diretiva da tempestividade, é a que viabiliza a antecipação de tutela em demandas repetitivas, dispensando o requisito da urgência.

Prosseguindo, não há relação hierárquica que a priori sobreponha um princípio constitucional a outro. Todos os valores postos na Constituição se equivalem em importância, especialmente aqueles do art. $5^{\circ}$, rotulados pelo Constituinte de "garantias fundamentais". Ocorre que a sua natureza aberta ocasionalmente os coloca em posições contrapostas na perspectiva dos casos concretos ${ }^{162}$. O exemplo mais próximo que se pode oferecer é o da própria colisão entre os valores segurança jurídica e tempestividade. Em várias passagens deste estudo ficou demonstrado que, em regra, tem-se menos tempo no processo contemporâneo do que as exigências da segurança jurídica reclamam. A tensão

\footnotetext{
${ }^{161}$ FARIA, Eduardo. A definição do interesse público. In: SALLES, Carlos Alberto (Org.). Processo civil e interesse público. São Paulo: Associação Paulista do Ministério Público; Ed. Revista dos Tribunais, 2003. p. 80.

${ }^{162} \mathrm{E}$ como posiciona Karl Larenz: "Os direitos, cujos limites não estão fixados de uma vez por todas, mas que em certa medida são 'abertos', 'móveis' (...) podem, justamente por esse motivo, entrar facilmente em colisão entre si” LARENZ, Karl. Metodologia da ciência do direito. 3. ed. Lisboa: Fundação Calouste Gulbenkian, 1997. p. 575.
} 
que se forma, assim, é por reduzir-se o procedimento, por acelerá-lo em nome do direito à prestação jurisdicional tempestiva (aspecto da idéia maior de efetividade). E, na medida em que o mal da demora está em especial evidência neste momento da "crise" do processo, a tendência é que a força de impulsão da tempestividade cresça em relação à força contrária da segurança jurídica. Passa-se, então, a um outro tipo de risco, qual seja a perda de qualidade da jurisdição. Nessa linha já se disse que a excessiva brevidade, tal como a excessiva demora, pode comprometer a própria efetividade da jurisdição ${ }^{163}$.

A tarefa de encontrar o ponto de equilíbrio depende da configuração de um problema específico a ser resolvido, pois os princípios não trazem soluções a priori, perfeitamente delimitadas como se verifica nas regras. O problema trará o contexto e nele é que se produzirá a solução, para o que o constitucionalismo vem desenvolvendo uma série de regras de interpretação.

J. J. Gomes Canotilho arrola seis normas de interpretação para conduzir o intérprete na solução das antinomias que se podem formar entre princípios constitucionais ${ }^{164}$, sendo certo que o trabalho de harmonização conduz a definir, no caso concreto, qual dos princípios em tensão deverá prevalecer ${ }^{165}$. Mas, às vezes, o legislador ordinário toma para si a tarefa de eleger o critério de harmonização, editando ele próprio regra de objetivação do trabalho do intérprete.

\footnotetext{
${ }^{163}$ "Il dirito di azione, al pare di ogni altro diritto fondamentale, dev'essere regolato e concretizzato dalla legge ordinaria da modo di assecurare l'effetività. E tale effetività può risultare compromessa sia per l'eccessiva brevità o l'eccessiva lunghezza dei termini cui viene assoggettata l'esperibilità della tutela giurisdizionale (...)".TROCKER, Nicolò. Processo civile e costituzione: problemi di diritto tedesco e italiano. Milano: A. Giuffrè, 1974. p. 251.

${ }^{164}$ Cabe destacar os quatro principais, que são: (a) princípio da unidade: a Constituição é um todo integrado, e o intérprete está submetido a essa idéia na sua atividade interpretativa; (b) princípio da máxima efetividade: em caso de dúvida, deve-se optar pela conclusão que reconheça maior eficácia aos direitos fundamentais. A origem deste princípio confunde-se com a tentativa de concretização das normas programáticas; (c) concordância prática: partindo da premissa de que os valores constitucionais têm igual hierarquia, o intérprete não pode sacrificar um princípio em prol de outro, devendo conduzir-se na busca do ponto de harmonização: "Subjacente a este princípio está a idéia de igual valor dos bens constitucionais (e não uma diferença de hierarquia) que impede, como solução, o sacrifício de uns em relação a outros, e impõe o estabelecimento de limites e condicionamentos recíprocos de forma a conseguir uma harmonização ou concordância prática entre estes bens"; (d) força normativa da constituição: deve-se preferir a interpretação que proporcione a eficácia ótima da lei constitucional, no sentido de mantê-la atualizada. CANOTILHO, J. J. Gomes. Direito constitucional e teoria da Constituição, cit., p. 1096-1099.

${ }^{165}$ Tratando das regras de solução dos conflitos, Canotilho esclarece que elas devem "construir-se com base na harmonização de direitos, e, no caso de isso ser necessário, na prevalência (ou relação de prevalência) de um direito ou bem em relação ao outro. Todavia uma eventual relação de prevalência só em face das circunstâncias concretas se poderá determinar, pois só nestas condições é legítimo dizer que um direito tem mais peso do que outro, ou seja, um direito prefere outro em vista das circunstâncias do caso". CANOTILHO, J. J. Gomes. Direito constitucional e teoria da Constituição, cit., p. 1140-1099.
} 
Tomando a doutrina do renomado jurista português, Teori Albino Zavaski localiza no direito brasileiro norma de harmonização daqueles princípios em situação específica, qual seja a do art. 273 do CPC, que, segundo ele, sobrepõe o princípio da efetividade ao da segurança jurídica, quando ocorrentes as situações lá previstas, que autorizam a antecipação de tutela $^{166}$.

Sendo esse o quadro das antinomias entre princípios constitucionais, e das soluções que o sistema desenvolveu para superar tais impasses, sua aplicação ao tema do presente trabalho revela significativa conclusão. Para demonstrá-la, tomemos a hipótese do art. 285A do CPC, que guarda simetria com o objeto do estudo, na medida em que se explica em um tipo específico de repetitividade.

Ao receber a demanda que repete anteriores pleitos já examinados e julgados, o juiz depara, do ponto de vista dos valores segurança jurídica e celeridade, com um quadro no qual não remanesce dúvida sobre o direito posto em causa; em que ele, juiz, compreendese pronto para julgar já no primeiro ato do processo. Em outras palavras, um quadro em que o quesito segurança jurídica se encontra suficientemente atendido. E é por isso que se justifica o julgamento imediato, pois já não existe tensão entre a celeridade e a segurança, impondo-se, satisfeita esta, que se dê passagem imediata àquela. Uma celeridade, vale mencionar, que beneficia mais intensamente a quem sequer é parte do processo, mas que mesmo assim realiza o fator efetividade, tanto do ponto de vista individual, como no âmbito dos escopos sociais e políticos da jurisdição.

Naturalmente estas são as linhas gerais. Há detalhamentos no art. 285-A, mediante os quais o sistema garante as eventuais excepcionalidades, permitindo o recurso ao próprio juiz e à instância superior, por exemplo.

A antecipação de tutela sem o requisito da urgência, que aqui se vai construindo como possibilidade no sistema brasileiro tem a mesma raiz: situações em que, ou inexiste tensão entre os dois princípios, ou ela é muito pouco significativa, recomendando o trânsito seguro da efetividade, resguardadas garantias ainda mais completas contra eventuais situações de exceção.

\footnotetext{
${ }^{166}$ ZAVASKI, Teori Albino. Antecipação de tutela e colisão de direitos fundamentais. Revista da Ajuris, Porto Alegre, n. 64, p. 395-417, 1995.
} 


\section{SEGUNDA PARTE - AS AÇÕES REPETITIVAS}

\section{Alguns exemplos práticos}

Para evitar que a teorização possa afastar da realidade concreta as idéias que se vêm formulando, é preciso abrir espaço para algumas demonstrações práticas que tornam mais fácil progredir com o tratamento do tema. Antes, no entanto, ressalve-se que os exemplos não encerram todas as possibilidades de utilização da técnica ora proposta, como é natural. Ou seja, eles não passam de uma amostragem que revela o sentido prático da antecipação de tutela sem o requisito da urgência em demandas repetitivas. Mas a proposta, enquanto resultado da teorização, é mais ampla que o universo reduzido das exemplificações.

Feita a ressalva, o primeiro núcleo que vale examinar é o da incidência de correção monetária em depósitos de poupança. Como é sabido, durante os anos de 1987 a 1991, foram editados vários planos econômicos no Brasil (Plano Bresser, Plano Verão, Plano Collor I e Plano Collor II) como decorrência do regime inflacionário que assolava o País, suscitando a ampla intervenção do poder público mediante normas para o controle da inflação. As intervenções se deram por intermédio de medidas provisórias, mais tarde convertidas em lei, e, no caso do sistema financeiro, também mediante portarias do Banco Central, definindo índices para a correção de depósitos em poupança a serem aplicados pelos bancos tomadores desses recursos.

Alguns anos mais tarde, os poupadores passaram a questionar a justeza dos índices utilizados pelo mercado financeiro, manejando argumentos diversos, sobretudo vinculados à idéia do direito adquirido. A síntese do debate nacional que se formou nos tribunais, então, foi por definirem-se judicialmente os percentuais de correção específicos para incidir em períodos determinados. E a matéria chegou ao STJ, onde foi sendo pacificada. Como exemplo, que ilustra suficientemente todo o conjunto, vale transcrever a ementa do Agravo Regimental no Recurso Especial 585.045/RJ, julgado à unanimidade, em 20-042004, pela quarta Turma do STJ, com a relatoria do Ministro Aldir Passarinho Júnior:

"ECONÔMICO. CADERNETA DE POUPANÇA. CORREÇÃO MONETÁRIA. CRITÉRIO. IPC DE JUNHO DE 1987 (26,06\%). PLANO BRESSER.

I - O Superior Tribunal de Justiça já firmou, em definitivo, o entendimento de que no cálculo da correção monetária para efeito de atualização de cadernetas de poupança iniciadas e renovadas até 15 de 
junho de 1987, antes da vigência da Resolução n. 1.338/87-BACEN, aplica-se o IPC relativo àquele mês em 26,06\%. Precedentes.

II - Agravo regimental desprovido."

Assim posicionada a premissa, imagine-se uma ação individual posterior em que o demandante pretenda contra seu banco justamente aquele índice para corrigir depósito de poupança no mencionado período. Seguindo a ritualística convencional do processo, mesmo que já tenha julgado diversos casos no sentido pretendido na inicial, e não obstante a pacificação inclusive no STJ, o juiz deverá citar o réu, que virá ao processo seguramente repetindo uma contestação-padrão, cópia de anteriores, apenas com o nome da parte alterado. Depois, se houver celeridade e organização acima da média nessa hipotética unidade judicial, o processo merecerá julgamento antecipado, com a inserção de sentença também igual a outras já lançadas em casos idênticos. O mesmo se diga do recurso de apelação e das contra-razões.

Prosseguindo, o juiz estará fadado a receber o apelo, pois não se aplica ao caso o art. 518, $\S 1^{\circ}$, do CPC, que autoriza o não-recebimento quando a sentença estiver de acordo com súmula do STJ e STF, já que não há súmula sobre essa matéria. Chegado ao Tribunal, mesmo havendo celeridade máxima também na segunda instância, com o julgamento monocrático (art. 557, do CPC), sobrevirão ainda os recursos subseqüentes, para só então retornarem os autos à primeira instância, na melhor das hipóteses em um ou dois anos a contar do ajuizamento. E então iniciará a execução (cumprimento da sentença), com seus fatores particulares de demora.

Durante a tramitação da demanda, o banco-réu emprestará o valor do crédito reclamado pelo demandante a terceiros a uma taxa de juros seguramente maior do que terá de pagar em juízo. Esse é um dos grandes atrativos da demora. Por outro lado, a resistência ferrenha do banco em só pagar no último momento desestimula outros correntistas a embrenharem-se no Judiciário atrás de seus direitos, desistindo deles, o que só faz multiplicar os ganhos da instituição financeira. E, numa economia capitalista, como é o ganho que determina o sentido da ação, nem se pode esperar que seja outra a postura do banco-réu do exemplo, senão essa de investir na demora do processo, uma vez que ela se apresenta como uma oportunidade de lucro.

Existem outros exemplos no âmbito do direito bancário, já em andamento ou em vias de eclodir. Tome-se o caso que emergiu com destaque na crise econômica de 2008 , 
relativo a operações de grandes empresas com derivativos de câmbio ${ }^{167}$, buscando racionalização de custos, mediante engenharias financeiras, ou equalização de riscos futuros em negócios internacionais. Em suma, firmaram contratos com bancos baseados na cotação futura do dólar norte-americano em patamares que a crise de 2008 desafirmou completamente. E com a disparada do valor daquela moeda, acumularam enormes prejuízos, algumas comprometendo sua própria existência. O problema já chegou à primeira instância do Judiciário, em teses com contornos que seguramente guardarão semelhanças estruturais ${ }^{168}$, cujo exame tenderá a firmar posições jurídicas a serem replicadas, depois, nos casos que se sucederem. Nessa linha de conjunto, aliás, o sugestivo comentário publicado em reportagem jornalística, atribuído a um dos juízes no Forum João Mendes na Capital paulista nos primeiros dias da judicialização do problema: "Mais um caso de derivativos. Coloque na pilha com os outros que vou estudá-los juntos"169

Fora do direito bancário, o segundo exemplo remete a uma prática muito usual entre seguradoras. Imagine-se alguém, vítima de prejuízos em acidente de trânsito, que apresenta os valores de sua pretensão à seguradora que cobre o risco do acidente, contratada que fora pelo motorista culpado. Na regulação do sinistro, parte da pretensão é admitida, com a glosa de determinados valores solicitados pela vítima, os quais a seguradora recusa pagar. Realizada a glosa, ela condiciona o pagamento da verba reconhecida à quitação geral dos prejuízos, de modo a impedir a cobrança futura das parcelas glosadas, prática conhecida no mercado de seguros. Para fechar a hipótese, imagine-se que o juiz, a quem o caso é apresentado, já presidiu outras demandas contra aquela mesma seguradora, em que essa prática foi repetidamente afirmada ilícita. Anote-se que o STJ tem posição firme, já há muito tempo, no sentido da ilicitude dessas condutas

\footnotetext{
${ }^{167}$ Segundo Paulo Sandroni, a expressão indica “operações financeiras cujo valor de negociação deriva (daí o nome derivativos) de outros ativos, denominados ativos-objeto, com a finalidade de assumir, limitar ou transferir riscos (..). Quando baseados no câmbio, "são derivativos financeiros os quais o contrato (futuros ou opções) se refere à taxa de câmbio de uma determinada moeda”.

${ }^{168} \mathrm{~A}$ complexidade desse tipo de negócio nem sempre permite ao cliente a compreensão exata dos riscos adicionais desconhecidos que, a pretexto de minimizar seus riscos conhecidos, pode estar assumindo. Há registros de quebras de grandes empresas por conta dessas incompreensões, como lembra Masakazu Hoji (Administração financeira: uma abordagem prática. 5. ed. São Paulo: Atlas, 2004. p. 234): “No período compreendido entre meados da década de 80 e os primeiros anos da década de 90, ocorreram grandes prejuízos com derivativos, em parte, por não serem seus efeitos claramente compreendidos pelos contratantes. A revista Capital Market Risk Advisor (Gazeta Mercantil, 6 nov. 1995, p. A-13), menciona como as maiores perdas verificadas em operações com derivativos as operações feitas pela Kashima Oil e Mettalgesellchaft, com perdas de US\$ 1,5 bilhão e US\$1,3 bilhão, respectivamente. Outro caso famoso foi o da falência do tradicional banco britânico Barings, em 1995”. Segundo a notícia jornalística referida na nota n. 158 infra, as reclamações que aportam ao Judiciário constroem-se nessa linha, da indução e erro e do excesso de ganhos pelos bancos, em prejuízo dos clientes.

169“TJ suspende contratos de derivativos" jornal O Valor, São Paulo, 28, 29 e 30 nov. 2008, p. E-1-E-2.
} 
(vide, por exemplo, o Recurso Especial n. 257.596-SP, julgado pela $4^{\mathrm{a}}$ Turma do STJ em 19-09-2000, Relator o Ministro Sálvio Figueiredo Teixeira)

A vítima, que tem direito de ação diretamente contra o segurador, dirige-se ao juiz pedindo que seja considerada ilegal a exigência e determinado à ré que, à falta de outras justificativas, pague o incontroverso sem o condicionamento da quitação integral. E pede a antecipação de tutela. A aplicação da proposta aqui sustentada admite a decisão imediata, determinando à seguradora, nos limites da pretensão do autor, que não condicione o pagamento à quitação de outras parcelas senão aquelas que estão sendo pagas. Uma ordem de abstenção de comportamento deferida sem o exame do perigo da demora, haja vista a evidência que as repetições anteriores, seja quanto ao comportamento daquela seguradora, seja quanto à ilicitude de prática, propiciam ao juiz enxergar.

Uma possível objeção neste caso seria a seguinte: o Judiciário reiteradamente desconsidera as quitações gerais nessas hipóteses, e admite as ações para a cobrança das diferenças glosadas pelas seguradoras. Então, o autor não teria interesse processual na propositura da ação objeto do exemplo, pois poderia assinar a quitação proposta, receber o incontroverso e, depois, reclamar na justiça o valor não pago.

Destaca-se a objeção, porque ela oportuniza revelar, por trás de um conjunto de rápidas decisões antecipatórias como aquela, uma relevante mensagem educativa que o Judiciário transmite ao mercado, desestimulando os entraves que tais posturas costumam impor aos indivíduos, e, por outro lado, estimulando o abandono da prática ilegal, com o que se tende a prevenir, a médio prazo, os prejuízos daqueles que, por haverem dado a quitação geral, julgam não ter direito e não reclamam. Sem contar a vantagem individual do autor da causa, pois, embora a posição firme da jurisprudência quanto à ilicitude do comportamento das seguradoras no ponto, sempre a oferta da quitação geral importará algum risco, o que demonstra haver, sim, o interesse processual na hipotética demanda.

Em patamares de litigiosidade mais reduzido, em termos de volume de causas, também se podem verificar exemplos que sugerem a utilidade da antecipação de tutela sem o requisito da urgência em demandas repetitivas.

Encerradas as eleições municipais, a nova administração de uma autarquia promove o remanejamento de locais de trabalho de um certo grupo de servidores, mediante atos praticados por gestor afirmadamente incompetente para aquela prática. Ou mediante algum tipo de vício formal, ou mesmo vício material. Examinando o caso na primeira ação 
proposta, o juiz, após a manifestação da administração, julga procedente a demanda e, mais tarde, o Tribunal confirma a sentença ${ }^{170}$. E assim sucessivamente em mais uma ou duas demandas que se seguem. Na quarta ação que eventualmente lhe seja dirigida, a repetição propiciará ao juiz suficiente clareza quanto a qual será o desfecho final, no momento em que a inicial aportar em sua mesa de trabalho. Já conhece as razões da administração, já se posicionou sobre a invalidade do ato, o Tribunal confirmou a sentença. Em um quadro assim, aguardar o transcurso do procedimento até o fim para, só então, realizar o direito já reconhecido a priori, é postura que não atende à racionalidade e, em nível jurídico, fere o princípio constitucional da tempestividade.

Este último exemplo comportaria demanda em litisconsórcio ativo ou mesmo demanda coletiva por parte da associação que representasse os servidores. Mas nem sempre se abrem essas vias, e, muitas vezes, elas são inadequadas. Veja-se que, na demanda coletiva, todos os funcionários seriam necessariamente trazidos de volta aos seus lugares de origem, o que pode desatender ao interesse de algum para o qual a nova alocação interessa. Quanto ao litisconsórcio ativo, pode ocorrer que nem todos confiem no mesmo advogado, ou que não tenham como arcar com a quota de honorários daquele específico advogado que representaria o grupo. E assim por diante.

\section{Antecipação da tutela em ações repetitivas sem o requisito da urgência: possibilidade e temas de interesse em torno da proposta}

A esta altura da exposição já é tempo de delimitar o núcleo da proposta e definir os temas que devem ser examinados para comprovar a sua existência e viabilidade no sistema processual brasileiro.

Na marcha convencional do processo, em primeiro lugar vem a fase postulatória, incluída aí a produção das provas que acompanham a inicial e a contestação. Depois, ocorre o momento da produção das provas em audiência e/ou as perícias e, por fim, a sentença. Como o duplo grau de jurisdição é a regra, segue-se a fase recursal, que, além

\footnotetext{
${ }^{170}$ Ao referir neste exemplo, como em outros, a preexistência de confirmação da instância superior, não se está indicando nisso um requisito indispensável para a operacionalidade do instituto. É possível a antecipação da tutela aqui preconizada, mesmo que não haja jurisprudência no tribunal. De modo que os exemplos estão assim construídos porque inseridos a meio caminho do trabalho, antes de abordadas todas as variáveis do tema, o que exige exemplificações algo extremadas, em condições de ilustrar mais facilmente o cenário que se vai construindo.
} 
dos recursos ordinários (apelação e embargos infringentes), pode envolver o acesso aos tribunais superiores, em caráter extraordinário, haja vista o contexto do regime federativo e do controle de constitucionalidade. Só após se poderá pretender realizar a decisão em seus efeitos práticos, no chamado cumprimento da sentença (quando necessário), também demarcado em fases específicas decorrentes do tipo de direito a ser concretizado, desde as obrigações pecuniárias que se realizam mediante subrogação e alienação de bens do devedor, até obrigações de fazer e não fazer que se cumprem mediante ordens judiciais ou providências correlatas tendentes ao exato adimplemento.

Há um enorme conjunto de previsões legislativas que buscam refinar o processo para diminuir a intensidade dos efeitos colaterais que produz, fundamentalmente vinculados à demora. São exemplos - já examinados - os procedimentos sumários, o julgamento antecipado e a antecipação dos efeitos práticos da tutela pretendida pelo autor da demanda. Esta última providência encontra previsões tanto em caráter particular, nos procedimentos especiais, como em caráter genérico, para quaisquer tipos de litígio. No primeiro caso, o exemplo que sempre vem é o das possessórias, em cujo universo, presentes os requisitos legais, antecipa-se a tutela até mesmo inaudita altera parte.

No âmbito do processo em geral, as providências antecipatórias encontram-se nos artigos 273, 461 e 461-A do CPC. Embora previstas para utilização generalizada em todos os tipos de processos, o legislador deu caráter excepcional ao seu manejo, na medida em que as vinculou a três hipóteses específicas, quais sejam (i) a urgência, (ii) o abuso do direito de demandar ou a protelação por parte do réu e (iii) a incontrovérsia tal como definida no $\S 6^{\circ}$ do mencionado art. 273. A regra, pois, é o cumprimento de todo o ritual do processo antes que se produzam os efeitos práticos, exceto quando aquelas situações específicas se verificarem, abrindo a via antecipatória.

Esse quadro não é completo, entretanto, em nosso entendimento, pois existe outra hipótese de viabilidade da antecipação da tutela, quando verificada a evidência do direito reclamado pelo autor em demandas repetitivas, antes de completar-se a seqüência de atos que, no processo convencional, são previstos como necessários para o reconhecimento e a realização do direito.

Registre-se que conceito de repetitividade adotado corresponde ao do art. 285-A do CPC, que gira em torno da locução casos idênticos, cuja sentido exato é explicitado no item 9, e subitens 9.1 e 9.2, abaixo. A idéia está suficientemente exposta em várias 
passagens deste trabalho, inclusive nas exemplificações, mas a delimitação precisa é a da norma legal.

Prosseguindo, a antecipação de tutela em questão constitui possibilidade operacional que se viabiliza geralmente no momento mesmo da propositura da ação, porquanto baseada em evidência que se forma pela percepção do juiz no seu trabalho em demandas anteriores. Assim delineada, não tem seu ponto de apoio na justificativa clássica que define a maciça maioria das providências dessa natureza, que é o periculum in mora associado à prova inequívoca de verossimilhança do direito alegado pela parte. Fundamenta-se só e só na evidência do direito.

Surgiu no sistema a partir da conjugação de diversos fatores. Primeiro, a especial natureza das demandas repetitivas em seus contornos internos e como conjunto, somada à expressão quantitativa que assumem no Judiciário, recomendando um tratamento otimizado. Trabalha-se, aqui, na linha da fronteira móvel entre as tutelas individuais e as coletivas, conforme longamente tratado em capítulos anteriores. Em segundo lugar, a ascensão do princípio da tempestividade ao nível de garantia constitucional, e, com base nisso, o tipo de influência que a repetitividade produz na tensão entre os valores segurança jurídica e tempestividade da jurisdição. Em terceiro, as reformas internas do Código de Processo Civil que, no conjunto, dão passagem ao novo tipo de tutela antecipada, sobretudo a edição do art. 285-A e a de outras reformas que, em paralelo, vão construindo no processo brasileiro uma nítida tendência de regulação diferenciada das demandas de massa. Por fim, é também decisivo na demonstração que se realiza nos tópicos seguintes, o fato da introdução do $\S 6^{\circ}$ no art. 273 do CPC pela Lei 10.444, de 07-05-2002, pois é justamente a exegese ampliada deste dispositivo que permitirá constatar no seu interior o modelo de antecipação de tutela aqui tratado.

É necessário ainda precisar a estreita vinculação da proposta com os direitos individuais homogêneos. Muito embora o conceito de repetitividade não se restrinja exclusivamente a esse tipo de direitos, como ficará claro adiante, é neles, e nas ações individuais que os veiculam em juízo, que a operacionalidade e a utilidade do instituto proposto se expressa talvez com maior destaque, pelo menos do ponto de vista quantitativo.

Ainda em reforço à idéia de que as repetições não se inserem todas no direito coletivo, embora este seja o seu núcleo de interesse maior, vejam-se as hipóteses em que o número de pessoas envolvidas em relações similares não chega a ser tamanho que 
justifique aquele tipo de tutela, mas que apresentam repetições em todas as unidades do conjunto (p. ex. o consumo de medicamento defeituoso por poucas pessoas, como situado linhas acima). Também quando, havendo origem comum entre vários direitos, o nível de homogeneidade é rarefeito e, por isso, a tutela coletiva revela-se menos eficiente que as individuais ( $n^{\circ} 3.3$, supra). Haverá repetições nessas hipóteses de homogeneidade rarefeita, no entanto, eventualmente propiciando a evidência suficiente para o deferimento de determinados tipos de antecipação de tutela. E há ainda outro setor, composto pelas pretensões constitutivas de grupos, que justamente pelo caráter constitutivo não se ajustam confortavelmente à tutela coletiva, pelo menos no estágio atual de seu desenvolvimento científico.

Não se deve esquecer, também, que o fenômeno das relações repetitivas pode produzir conflitos em sentido inverso àquele que se está habituado enfocar. Tome-se o caso concreto de um sindicato, que, para beneficiar seus associados com o barateamento de custos no uso de telefones celulares, contrata com empresa de telefonia o fornecimento de certo volume de ramais que, pelo conjunto, importam custos individuais mais baratos. Um tipo de "plano empresarial", jargão que o setor utiliza para designar a contrapartida do preço individual mais barato nas contratações de conjuntos. O responsável perante a companhia telefônica é o sindicato, o que importa relação continuativa paralela entre o sindicato e os sindicalizados. Verificadas as adesões ao longo do tempo e os inadimplementos de várias naturezas e em momentos diversos, sucedem ações individuais propostas pelo sindicato contra os sindicalizados. Não vem ao caso detalhar, a título de exemplo, cada qual dessas demandas e as zonas em que se podem verificar repetições entre elas, pois o objetivo aqui é destacar apenas o aspecto peculiar do direcionamento das ações, que partem do agente individual (o sindicato) em direção ao corpo coletivo dos associados (os usuários de celulares do plano empresarial do sindicato). Uma manifestação coletiva em que se poderá aferir intensa homogeneidade entre as reclamações veiculadas em cada demanda individual, na exata proporção das repetições que puderem ocorrer entre elas. E, no entanto, é hipótese que não se ajusta às ações coletivas, concebidas para operar na direção inversa.

Em suma, o ambiente no qual se sustenta a antecipação de tutela em demandas repetitivas é formado, em seu núcleo, por situações litigiosas completamente ajustadas ao universo da tutela coletiva de direitos, que, no entanto, são veiculadas em juízo mediante ações individuais, sem a perspectiva de que esse fenômeno venha a cessar em curto espaço 
de tempo. Há outras hipóteses, mas o núcleo é aquele. E assim os princípios que informam o direito coletivo fundamentam a proposta ora apresentada. Sobretudo na acepção social e política da jurisdição.

Vencida a primeira parte, destinada a identificar e delimitar a proposta, é necessário agora comprovar a possibilidade da sua confirmação na perspectiva da dogmática processual. Este é o conteúdo dos itens que seguem, orientados por duas linhas condutoras, que são a repetitividade, por um lado, e a antecipação de tutela, por outro. Destaca-se, ainda, o direito probatório no contexto da repetitividade, que traz à tona os institutos do fato notório e das máximas da experiência, instrumentos que apresentam renovado vigor quando manejados na dinâmica das ações de massa.

\section{A repetitividade e a cultura de massa}

O fenômeno da repetição nos tempos atuais envolve-se com o próprio estilo de vida nas sociedades de massa. A moda cria padrões que se repetem em escala nos indivíduos; a competitividade da indústria do consumo exige que o fabricante adapte rapidamente seu produto incorporando hoje a novidade que o concorrente implantou ontem, repetindo-o. Exemplos marcantes dessa corrida de repetições podem ser observados nas tecnologias de telefones celulares (acesso à internet, máquinas fotográficas, etc) e nos acessórios de automóveis. Mesmo no ramo dos serviços, as facilidades que um banco oferece são logo adotadas pelo concorrente (atendimento on line, caixas eletrônicos para saques 24 horas por dia, etc). Tudo gerando progressiva padronização.

O comércio das grandes cidades concentra-se em centros de vendas (shopping centers), cujas relações contratuais com os lojistas, horários de funcionamento, promoções e o próprio design são demasiado semelhantes, constituindo um padrão comercial largamente utilizado por todos que orbitam esse enorme setor comercial brasileiro e mundial.

Os grandes conglomerados empresariais organizam-se impondo padrões em todos os níveis de suas relações, sejam as internas, entre seus colaboradores, sejam as externas, com o mercado, às vezes até com a edição e publicação em sites da internet de manuais próprios de conduta, o que torna previsíveis suas ações futuras que repetirão códigos padronizados. 
A publicidade é outra fonte de criação de standards; estilos que cria e recria a partir dos perfis dos consumidores que os departamentos de mídia tão bem identificam.

A mundialização de modelos: há alguns anos, quando se viajava ao exterior, era marcante a diferença dos modelos de automóveis nos diversos países, hoje praticamente idênticos em todas as partes do mundo.

Esses são exemplos mais coloquiais da padronização, que se insere progressivamente por todos os lados, seja porque a urbanização agrupa em espaços pequenos enormes contingentes de pessoas, potencializando a característica humana de assimilar padrões do grupo, seja porque a economia estimula a padronização ${ }^{171}$ para garantir os ganhos de escala.

Outro fator que interage de maneira fulgurante no contexto é a informação, em duas acepções: a de seu volume e a da sua rapidez. Há notícias que se mundializam em poucas horas. E a padronização se alimenta dessa facilidade, economicamente acessível a um enorme contingente de pessoas.

Em suma, tudo é muito igual na atualidade, donde se pode concluir que, cada vez mais, a vivência do juiz e a notoriedade dos padrões de conduta da grande maioria dos litigantes indicam qual será a solução do caso muito antes do final do processo, pois à medida que as demandas reproduzem a vida social, as padronizações saltam para dentro dos processos propiciando a visão do litígio e de sua solução para além dos elementos de prova específicos que as partes trazem para os autos. É um fenômeno de grande penetração que seguramente supera o universo das ações repetitivas, com amplas fronteiras para serem exploradas e ao que parece com possibilidade de alterar significativamente o que se entende por convencimento necessário para solver as controvérsias.

Como seria de esperar, a conjuntura social pressionou o sistema jurídico, que passou a se informar dessa realidade renovada e a normatizá-la. E assim o tema chegou ao processo civil brasileiro, em que o projeto das reformas parciais vem contemplando progressivamente a regulação de situações decorrentes da massificação, com modelos de racionalização examinados no tópico seguinte.

\footnotetext{
${ }^{171}$ John Ralws, examinando a estrutura utilitarista das sociedades ocidentais, afere o movimento no sentido de construir padrões para "organização dos desejos de todas as pessoas num único sistema coerente de desejos”. E arremata o filósofo: "é por meio dessa construção que muitas pessoas se fundem numa só", com o que conclui: "O utilitarismo não leva a sério a diferença entre as pessoas”. RAWLS, John. Uma teoria da justiça. São Paulo: Martins Fontes, 1997. p., 29-30.
} 


\section{A jurisdição e a repetitividade}

Na organização do Poder Judiciário não existe hierarquia funcional, tal como ocorre na Administração pública. Cada magistrado, no exercício da jurisdição e nos limites estabelecidos pelas regras de competência, é independente e age conforme sua livre convicção sobre os fatos e o direito. A independência e a liberdade de convicção do juiz são valores que pertencem originariamente à sociedade, de modo a garantir a imparcialidade, pilar da jurisdição no estado de direito.

Mas, uma vez praticado o ato jurisdicional, ele pode ser revisto, em caráter ordinário ou extraordinário, e eventualmente ser reformado ou anulado. No sentido do valor da decisão, portanto se sobrepõe aquela oriunda dos tribunais superiores às dos outros, e destes em relação aos juízes singulares. Há, aqui, no interior de um mesmo processo, o dever de acatamento por parte do juiz singular, nos atos de cumprimento, da decisão do tribunal contrária à sua sentença.

Esse sistema, que mescla a liberdade e o acatamento, propicia a qualificação da jurisdição, considerando que, mesmo um juiz em início de carreira, na mais longínqua comarca, pode interagir com posições jurisdicionais anteriores adotadas até pelos magistrados do Supremo Tribunal Federal, por exemplo, divergindo delas em julgamentos posteriores e assim contribuindo para o aperfeiçoamento do direito, que com esse nível de influência renovada tenderá a permanente atualização.

Em paralelo, a ampla liberdade gera o efeito colateral da possibilidade de decisões contrárias para casos idênticos. E, se se tratar de questões muito recorrentes, a segurança jurídica e a legitimidade do Judiciário restam comprometidas no sentimento daqueles que, indo a juízo, tendem a imputar o resultado menos ao direito do que à sorte da distribuição do processo para este ou aquele juiz.

Outro aspecto de se notar nessa intrincada discussão é que a postura de um juiz singular que se contraponha ao sentido das decisões de um tribunal - mesmo o enunciado de súmula - com argumentos renovados, propondo um diálogo jurídico, é desejável e realiza os objetivos do sistema. Essa liberdade deve ser realmente preservada. O problema é quando ela degenera, e então deixa de haver debate, pois já não existe mais diálogo e tudo se resume na insistência em continuar julgando contrariamente ao que a instância superior pacificou. Esse nível de endurecimento pode ultrapassar o sentido que justifica a 
liberdade de convicção do juiz, transformando-se em desafio à lógica do duplo grau de jurisdição.

Por trás de tudo, potencializando o problema das decisões divergentes entre juízes de mesma instância, ou entre estes e os de instância superior, está o fenômeno dos casos idênticos, vale dizer: a repetitividade. Não fosse ela, esses impasses não se formariam. De outra parte, quanto maior a sua intensidade, mais visíveis as eventuais fragilidades internas do sistema da justiça para o tratamento de casos repetidos.

A uniformização de jurisprudência e, principalmente, a edição das súmulas, foram reações do processo procurando construir convergências no universo das repetições. Quanto ao chamado direito sumular, mediante a publicação de sínteses breves dos consensos acerca de pontos litigiosos recorrentes, com o fim de estabilizar a compreensão do direito não pela exigibilidade própria das normas, mas pela persuasão que a autoridade institucional do órgão judiciário confere.

Mas a pressão da repetitividade se intensificou sempre mais, empurrando o sistema para o desenvolvimento de novas alternativas, a ponto de ser possível afirmar, hoje, uma autêntica tendência do processo civil brasileiro no sentido de que a jurisdição da litigiosidade repetitiva seja adaptada aos contornos de seu objeto, tanto aproveitando oportunidades que os conjuntos oferecem, como ajustando o ponto de equilíbrio da relação entre a independência do juiz e o dever de consideração que deve ter pelas posições consolidadas dos tribunais, naqueles termos colocados acima.

É nesse quadro que ingressaram na literalidade das normas processuais expressões como súmula vinculante, jurisprudência dominante ${ }^{172}$, casos idênticos, idêntica controvérsia, idêntica questão de direito, etc, compondo um mosaico que merecerá especial consideração no tópico seguinte.

Trata-se de um provável segmento específico que se vai construindo dentro do processo, cuja característica básica é a repetitividade, implicando a edição de normas e raciocínios técnicos para serem utilizados tão-só no universo das repetições, conforme exame no tópico seguinte. A racionalidade desse segmento (que é a racionalidade da

\footnotetext{
${ }^{172}$ Em nível constitucional, o tema remete ao papel dos tribunais superiores que, não devendo constituir propriamente uma nova instância recursal sobreposta ao duplo grau de jurisdição, têm por atribuição garantir a unidade do direito, principalmente em vista da chamada criatividade judicial que é inseparável do papel ampliado dos juízes na criação do direito ao aplicá-lo aos casos concretos, em vista dos espaços indeterminados que o legislador propositalmente deixa inseridos nas normas, como já foi estudado em tópicos anteriores. Nesse sentido o estudo de Mônica Sifuentes: Súmula vinculante: um estudo sobre o poder normativo dos tribunais. São Paulo: Saraiva, 2005.
} 
jurisdição de massa) não pode escapar de suas fronteiras, entretanto, a fim de não gerar resultados indesejáveis. Por exemplo: talvez não faça sentido, nos casos muitíssimo repetitivos, em que haja posição consolidada nos tribunais superiores, o mesmo tipo de liberdade do juiz para discordar de posições dos tribunais que deve ter na jurisdição convencional. Mas como traçar os parâmetros dessa liberdade mais reduzida? Afinal, o critério da repetitividade, em si mesmo, não é suficiente, pois repetições com baixo grau de intensidade estão mais próximas da jurisdição convencional do que da de massa.

Essa fuga dos limites a que devem ficar restritas as formulações destinadas à jurisdição de massa, pode ser exemplificada na doutrina de Luiz Guilherme Marinoni e Sérgio Cruz Arenhart, na seguinte passagem: "afirmar que o juiz tem o direito de julgar de forma diferente dos tribunais superiores constitui gritante equívoco” ${ }^{173}$. Tal assertiva, que vem compondo capítulo titulado "julgamento de ações repetitivas” pode ser, a um só tempo, verdadeira e falsa, dependendo do grau de intensidade das repetições. Tratando-se do Plano Bresser e, pois, do índice a ser utilizado para corrigir depósitos de poupança, a locução é tendencialmente verdadeira. Mas, se tomarmos, por exemplo, o caso da Súmula 145 do $\mathrm{STJ}^{174}$, que trata do transporte de cortesia, limitando a responsabilidade do motorista em casos de acidente com danos ao carona só às hipóteses de dolo ou culpa grave, talvez não se deva engessar de maneira tão absoluta a possibilidade de rediscussão pelas instâncias ordinárias, principalmente no estágio atual do trânsito das grandes cidades.

Por isso se tem procurado enfatizar que o raciocínio do operador contemporâneo do processo há de ter sempre presente a distinção entre os dois tipos de demandas (as de massa e as convencionais). Se não, generalizações do tipo daquela supra-referida podem conduzir a um cenário, tanto ou mais preocupante que o do congestionamento do Judiciário, em que a tarefa do juiz de primeira instância fica algo reduzida, na perspectiva da interpretação do direito, a repetições de enunciados jurisprudenciais. Um "juizfuncionário" com roupagem ligeiramente diversa do juiz boca da lei.

\footnotetext{
${ }^{173}$ MARINONI, Luiz Guilherme; ARENHART, Sérgio Cruz. Processo de conhecimento. 7. ed. rev. e atual. São Paulo: Ed. Revista dos Tribunais, 2008. v. 2, p. 97.

${ }^{174} \mathrm{O}$ teor do enunciado 145 da Súmula do STJ é o seguinte: "No transporte desinteressado, de simples cortesia, o transportador só será civilmente responsável por danos causados ao transportado quando ocorrer dolo ou culpa grave"
} 


\subsection{A repetitividade em técnicas processuais}

A Lei 11.672, de maio de 2008, inseriu no CPC o art. 543-C, que em última análise prevê o sobrestamento da massa de recursos especiais fundamentados em idêntica questão de direito, isolando alguns deles para serem julgados, nos quais se formará a decisãopadrão para depois ser replicada em todos os demais. Há detalhes operacionais que não vêm ao caso, tanto a respeito de onde e como se dá a suspensão, quanto sobre a forma de replicar a decisão supra-referida, etc. O que importa, aqui, no entanto, é perceber a enorme transformação de padrões operacionais por um Judiciário que procura encontrar caminhos para o enfrentamento de conjuntos litigiosos. Na mesma linha, a Lei 11.418, de dezembro de 2006, que inseriu os artigos 543-A e 543-B no CPC, prevendo o sobrestamento de recursos extraordinários dirigidos ao $\mathrm{STF}$, nos quais o requisito da repercussão geral deva ser definido no julgamento de algumas unidades do conjunto de casos ligados por idêntica controvérsia, para depois ser reproduzida em todos os demais, resolvendo, assim, rapidamente, a massa de ações repetitivas.

Outra manifestação da intensa repetitividade no processo é a súmula vinculante prevista no art. 103-A da Constituição Federal e regulamentada pela Lei 11.417 , de dezembro de 2006, como providência para uniformizar a compreensão do direito já não mais só pela autoridade institucional acima tratada, quando se falou em direito sumular, mas pelo efeito vinculante dirigido aos órgãos do Poder Judiciário e da Administração.

Fora do contexto da repetitividade, o instituto talvez pudesse converter-se em sério risco à liberdade e independência da magistratura. Mas justificado como foi na "controvérsia atual que acarrete grave insegurança jurídica e relevante multiplicação de processos sobre idêntica questão" (art. $2^{\circ}, \S 1^{\circ}$, da Lei 11.417), remete ao universo da jurisdição de massa, em cujo contexto não deve significar mais do que a adaptação da idéia de que as decisões dos tribunais superiores prevalecem sobre decisões de juizados de menor hierarquia. E à provável objeção que se quisesse lançar, sobre ser essa prevalência viável apenas no interior de um mesmo processo, a resposta há de ser o que diria um observador externo olhando a repetitividade no interior do Judiciário: o processo novo é o mesmo processo já julgado tantas vezes, apenas alterado o nome das partes. Tudo isso, naturalmente, nos limites do preceito da súmula vinculante. 
Com as devidas ressalvas que a teoria do processo exige sobre o significado da identidade de ações, o fato é que a recorrência de algumas expressões utilizadas pelo legislador para designar as identidades próprias do fenômeno da repetitividade no processo (casos idênticos ou idêntica controvérsia, por exemplo) andam bem próximas do enunciado pelo hipotético indivíduo que olhasse de fora o Judiciário.

Tudo isso importa muito para o fim que se persegue neste trabalho. O sentimento de obviedade que se procura descrever com o recurso à metáfora do observador externo, uma vez transferido para o tema da demora da decisão, constrói todo um sentido para sustentar-se a tese de que as identidades, que revelam prima facie a procedência da pretensão do autor, justificam um tratamento procedimental adaptado, na linha da tendência pela qual o legislador vem adaptando a litigiosidade de massa, principalmente mas não exclusivamente - no âmbito dos recursos.

Para além das técnicas até aqui tratadas, que se destinam a vigorar mais especificamente no âmbito dos tribunais superiores, há outras regulações do mesmo gênero, para operar também em outros níveis da justiça, nas quais o ponto de referência é a jurisprudência dominante do próprio tribunal que julga, ou a dos tribunais superiores, ou do STF, inclusive a jurisprudência expressa em súmulas não-vinculantes. Estão relacionados a tal formulação os seguintes dispositivos do CPC: (a) art. 120, parágrafo único, que autoriza decisão monocrática do relator em tema de conflito de competência, se a jurisprudência dominante do tribunal a que pertence estiver posicionada no mesmo sentido da sua decisão; (b) art. 481, parágrafo único, autorizando a negativa de seguimento à argüição de inconstitucionalidade, se conforme com jurisprudência majoritária interna, ou do plenário do STF; (c) art. 475 do CPC, $\S 3^{\circ}$, que confere executividade a decisões contra a Fazenda Pública, antes do trânsito em julgado, desde que fundadas em súmula dos tribunais superiores ou jurisprudência do plenário do STF; (d) art. 518, § $1^{\circ}$, pelo qual é possível ao juiz singular negar seguimento a recurso de apelação, quando a sentença estiver fundada em súmula do STF ou STJ ${ }^{175}$; (e) art. 544, $\S 3^{\circ}$ e $4^{\circ}$, que trata de agravo contra decisões que negam seguimento a recursos especiais ou extraordinários, autorizando o relator a acolher o recurso no próprio instrumento de agravo, desde que baseado em jurisprudência dominante ou súmula do STJ ou STF, respectivamente; (f) art. 557, caput e parágrafo $1^{\circ}$-A, prevendo a possibilidade de acolhimento ou desacolhimento sumário de

\footnotetext{
${ }^{175}$ Trata-se da "súmula impeditiva de recurso" que se tentara instituir na Emenda Constitucional 45, mas que não foi aprovada, no ponto, pelo Senado Federal, conforme: MOREIRA, José Carlos Barbosa. Comentários ao Código de Processo Civil. 14. ed. rev. e atual. Rio de Janeiro, Forense, 2008. v. 5, p. 460.
} 
recursos (por decisão monocrática do relator), se conformes ou contrários, respectivamente, à súmula ou jurisprudência dominante do próprio tribunal, do STF, ou de tribunais superiores.

Por fim, o art. 285-A do CPC, tal como um terceiro gênero entre a súmula vinculante e a jurisprudência majoritária dos tribunais, instituiu a possibilidade da sentença de improcedência prima facie baseada em decisões anteriores tomadas pelo mesmo juízo em casos idênticos. O tema será tratado em tópico específico mais adiante, pelo que fica apenas referido por enquanto.

\subsection{A repetitividade no processo: tendência e limites}

Retornando à classificação das causas "exógenas" e "endógenas" de demora dos processos judiciais, e examinando naquele contexto as técnicas criadas pelo legislador nos dispositivos examinados no item acima, o que se pode afirmar, de saída, é que todas aquelas técnicas atuam nas duas frentes, procurando diminuir o número de processos e, simultaneamente, abreviando os procedimentos. De resto, essa atuação simultânea se explica em que os dois fatores de demora se relacionam em uma espécie de sinergia ${ }^{176}$, como já examinado, um alimentando-se do outro. Mas, fora do âmbito da sinergia, o que se percebe a um segundo olhar é que, tendencialmente, as duas primeiras espécies de providência direcionam-se mais ao combate do congestionamento do Judiciário, ou seja, ao enfrentamento das causas exógenas. Em especial o sobrestamento de processos semelhantes para aguardar o julgamento de um ou mais casos paradigmáticos, em que se produzirão decisões para serem replicadas nos demais. No outro extremo, a sentença de improcedência prima facie destaca-se como um peculiar mecanismo de atalho procedimental, fator de neutralização da demora interna dos processos.

Tal configuração permite identificar as duas linhas do que se denominou a tendência do processo contemporâneo em adaptar a sua técnica ao fenômeno das repetições. A tentativa de edição de um código específico para regular as ações coletivas, como visto, é outra manifestação dessa tendência, que não tem como retirar do processo

\footnotetext{
${ }^{176}$ Luiz Guilherme Marinoni refere essa sinergia em que a demora do conjunto prejudica as unidades, e viceversa. Ao fazê-lo menciona estudo da Corte Suprema dos Estados Unidos acerca do problema. MARINONI, Luiz Guilherme. Tutela antecipatória e julgamento antecipado: parte incontroversa da demanda. 5. ed. São Paulo: Ed. Revista dos Tribunais, 2003. p. 29.
} 
civil convencional todo o fenômeno, no entanto, como várias vezes comprovado em exames anteriores.

Outra vantagem da visualização conjuntural é perceber a nítida divisão interna que vai sendo formada no processo, entre a maneira de se realizar jurisdição convencional e a massificada, que, em expressão vulgar, se denominou "jurisdição de varejo" e "jurisdição de atacado". Este é talvez o ponto mais relevante, para evitar a contaminação de uma pela outra. Ou seja, para evitar que o uso de mecanismos construídos para debelar os conjuntos, passe a regular a jurisdição convencional.

Principalmente, o olhar conjuntural permite ajustar a compreensão do fenômeno na cultura que se vai formando paulatinamente na consciência dos operadores, evitando equívocos, por um lado, e acelerando a adoção de oportunidades que o contexto oferece, por outro, tanto no uso consciente e sem constrangimentos de técnicas próprias da gestão de conjuntos e da própria burocracia para julgar ações repetitivas, como a percepção de novos institutos, tal como a antecipação de tutela aqui proposta, que emerge da repetição como fator que produz convencimento prima facie, apenas em sentido inverso ao do art. 285-A do CPC.

\section{A repetitividade e a improcedência prima facie: art. 285-A do CPC}

As aproximações que vêm sendo feitas entre o artigo 285-A do CPC e a antecipação de tutela em demandas repetitivas sem o requisito da urgência exigem delimitação precisa dos pontos de contato e das zonas de afastamento entre as duas técnicas, o que se passa a examinar neste item e no subseqüente (n. 10). Desde já fica a ressalva, no entanto, que o estudo da sentença de improcedência prima facie não será integral, dispensando o exame de questões particulares não relacionadas com o tema do presente trabalho $^{177}$.

\footnotetext{
${ }^{177}$ A título ilustrativo, tome-se o debate sobre se, ao proferir a sentença prima facie com base em outras sentenças que formam o precedente, o juiz deve transcrever as sentenças anteriores ou apenas mencionar a sua existência. Outra hipótese de discussão particular daquele dispositivo, que é irrelevante nesta exposição é o de saber se é cabível a aplicação do dispositivo quando uma ou mais das sentenças anteriores foi de parcial procedência, etc. Essas e outras discussões constam em artigo de doutrina de Fernanda Guedes Pinto (Ações repetitivas e o novel art. 285-A do CPC. Revista de Processo, São Paulo, v. 32, n. 150, p. 141147, ago. 2007). Por fim, não será objeto de exame a ação de inconstitucionalidade proposta pela Ordem dos Advogados do Brasil contra a Lei 11.277/2006, que inseriu o dispositivo no CPC, ainda pendente de julgamento.
} 
O teor literal da norma é o seguinte:

Art. 285-A. Quando a matéria controvertida for unicamente de direito e no juízo já houver sito proferida sentença de total improcedência em outros casos idênticos, poderá ser dispensada a citação e proferida sentença, reproduzindo-se o teor da anteriormente prolatada.

$\S 1^{o}$. Se o autor apelar, é facultado ao juiz decidir, no prazo de 5 (cinco) dias, não manter a sentença e determinar o prosseguimento da ação.

$\S 2^{\circ}$. Caso seja mantida a sentença, será ordenada a citação do réu para responder ao recurso.

Para orientar o exame, tomemos o exemplo de um consumidor que sofra o corte da energia elétrica em sua residência por falta de pagamento das três últimas mensalidades, e promova ação contra a distribuidora para que retome o fornecimento com base em alegado direito à continuidade desse serviço essencial, independentemente do atraso na contraprestação. Trata-se de debate que mereceu destaque na jurisprudência, inclusive sob o argumento de que o corte de luz estaria servindo como meio de cobrança de dívidas. No STJ, a posição dos magistrados dividiu-se durante algum tempo, pacificando-se, depois, o entendimento sobre licitude do corte em vista de inadimplemento de mensalidades recentes. Nesse sentido o Recurso Especial 588.763/MG, julgado pela $2^{\mathrm{a}}$ Turma do STJ, Relatora a Ministra Eliana Calmon.

Recebida a hipotética ação, o juiz, que já julgou improcedentes ações anteriores por convencer-se da inexistência do direito à continuidade naquelas condições de nãopagamento, julga de plano improcedente também esta nova ação, na forma do art. 285-A do CPC. Este é o exemplo para orientar o exame dos pontos específicos a seguir alinhados.

\subsection{O sentido da locução "casos idênticos"}

A primeira questão que exige ser precisada na literalidade do artigo 285-A é o sentido da locução casos idênticos. Talvez nem fosse necessário dizer, tal a obviedade, que não se trata de ações idênticas, o que retiraria todo o sentido da norma. Também não parece acertado afirmar a identidade de causa petendi entre as ações já julgadas e a nova ação objeto de julgamento prima facie. Isto porque a causa de pedir é composta "do fato $e$ dos fundamentos jurídicos do pedido" (art. 282, III, do CPC), com o que, para 
compartilharem a mesma causa petendi, as ações teriam de originar-se do mesmo fato e mesmos fundamentos jurídicos.

Visto assim, para que a exegese do art. 285-A fosse a da identidade de causas de pedir, os cortes de luz das ações julgadas antes e depois teriam de ser o mesmo corte, o que absolutamente não confere com o sentido da norma. Neste ponto, é útil remeter à discussão proposta linhas acima sobre a natureza de conjunto que caracteriza as ações de massa no seu modo de expressão em juízo, mesmo quando ajuizadas individualmente, como também ao fato de que a relação entre as unidades desse conjunto se dá pela similaridade e não necessariamente pela identidade ${ }^{178}$. Também vale o alerta: os institutos próprios do processo convencional, como o da causa de pedir, não têm como acomodar integralmente as necessidades das manifestações do direito coletivo, e exigem adaptação para ajustaremse ao objeto coletivo.

Desse modo, o máximo a que se pode chegar é à afirmação de que casos idênticos significa, em nível de institutos convencionais do processo, demandas que apresentem causas de pedir similares.

Seguindo essa lógica, os cortes de fornecimento de energia em vista de atrasos de mensalidades recentes, como fundamentos de fato, somados ao fundamento jurídico do direito à continuidade da prestação, que os demandantes anteriores manejaram, é o suficiente para que se conclua serem aquelas demandas já julgadas casos idênticos, autorizando que outras que sobrevenham possam ser catalogadas nessa mesma condição de similaridade. Não importa que nas causas precedentes o inadimplemento de um consumidor terem sido de três mensalidades no ano de 2006, e o de outro, quatro mensalidades em 2007. O que importa é o núcleo ser semelhante, e as sentenças repetitivas se tenham concebido nos limites dessas questões nucleares. Mas tal similaridade há de configurar um padrão de agir, um liame entre as várias situações trazidas a juízo, pelo que seria inviável buscar precedentes em contextos históricos já consumidos pelo tempo - sem atualidade -, ainda que formalmente adequados à letra da lei e oriundos do mesmo juízo. Nem se trata de limites temporais, é bom dizer, mas de atualidade no sentido de os precedentes e o caso em julgamento constituírem parte de um conjunto. Retorna, aqui, o debate inserido no título "a repetitividade na cultura de massa" (n. 7, supra), conectando a

\footnotetext{
${ }^{178}$ Pode até haver identidade fática, tal como na poluição de um rio que provoque várias ações indenizatórias individuais, conforme exemplo cogitado no capítulo relativo aos direitos coletivos. Mas por certo o art. 285-A do CPC não se restringe a esse tipo de situações, o que limitaria enormemente a sua utilidade.
} 
jurisdição de massa mediatamente aos padrões que o modelo de vida contemporânea dissemina e que são vivenciados pelo juiz como membro daquela sociedade, vivência essa cujo valor no processo se revela na operação das máximas da experiência, tratadas com maior detalhamento em tópico específico, abaixo.

Necessário referir, entre parênteses, e fechando esta parte, que vale para o art. 285A a mesma nota destacada linhas acima sobre que, destinada a incidir em causas de natureza coletiva ajuizadas em demandas individuais, a norma também abarca aquelas outras demandas na linha de fronteira entre o individual e o coletivo, em que as repetições, posto menos intensas, sejam suficientes para o manejo do instituto.

\subsection{Os fatos e o direito no âmbito do art. 285-A do CPC}

Conforme a letra da lei, é requisito para o julgamento prima facie que a controvérsia seja apenas de direito. Ocorre que nessas demandas, como em todas, o suporte de fato constitui um prius lógico inseparável da definição do direito. E, se não pode haver controvérsia sobre o conjunto de fatos, sobrevém inevitável a indagação sobre como é possível, sem oportunizar a presença da outra parte, que os fatos atinjam a condição de incontroversos para o fim de ensejar a sentença final de uma demanda.

Aqui ocorre uma daquelas oportunidades que a coordenação de contingências e princípios do processo às vezes oferece ao legislador, do que é exemplo a técnica monitória - em que o título executivo se forma prematuramente pelo aproveitamento do silêncio do afirmado devedor. Em certa medida, o uso da técnica em questão pode até abstrair o fato de que obrigado eventualmente não seja verdadeiramente devedor. Vale mais, no caso, ter sido oportunizada a defesa do que a eventual verdade por trás do silêncio às vezes descuidado do apontado devedor. $\mathrm{O}$ modo de fazer-se o processo envolve esse tipo de pragmatismos, sem os quais a justiça estancaria em uma indefinição permanente.

Também por vias transversas compõe-se o caráter incontroverso dos fatos da inicial na incidência do art. 285-A do CPC. É o sentido da decisão de improcedência que, por beneficiar quem poderia controvertê-los, libera o julgador para tomar como verdadeiros os fatos alegados, mesmo que eventualmente não o sejam, sem preocupar-se com o caráter substancial dessa verdade. Assim, se alguém afirma-se titular de contrato de fornecimento 
de energia, quando na verdade realizou um acesso clandestino ao serviço ${ }^{179}$, e vai a juízo para reclamar que seja religada a luz sob o pretexto do direito à continuidade da prestação, receberá o julgamento como se verdadeira fosse a existência do contrato. Aquela é uma verdade na qual o juiz baseará a improcedência. E como se trata da melhor posição ao demandado, o aspecto da fraude, que seria fatalmente controvertido pelo réu, consome-se na improcedência.

Por aí percebe-se que a extensão compreendida na locução casos idênticos não se restringe só ao direito, incluindo também os fatos. A circunstância de exigir-se, quanto a estes, apenas um convencimento formal, como explicado acima, não obscurece a exata abrangência da norma. E a necessidade de dar destaque a este aparente pormenor está em que o art. 285-A inaugura uma possibilidade realmente nova no processo, qual seja o intercâmbio entre demandas diversas para o fim de propiciar decisão. Nessa linha, definir que o intercâmbio se dá no âmbito dos fatos e do direito é deveras importante, mais do que para o fim da improcedência prima facie, para a construção do raciocínio acerca da antecipação da tutela sem o requisito de urgência em demandas repetitivas, como poderá ser constatado mais adiante.

\subsection{O tratamento das situações excepcionais na incidência do art. 285-A do CPC}

Todo o atalho que se intente fazer na ritualística do processo exige a reserva de algum espaço para o trânsito das excepcionalidades, que, por fugirem à regra, ficam expostas a eventuais injustiças. Trata-se de uma constante que revela ainda uma vez a força do paradigma da ordinariedade como modelo dimensionado para veicular as conquistas da civilização ocidental ínsitas na ampla defesa e no contraditório.

No âmbito da sentença prima facie de improcedência, o mecanismo localiza-se nas disposições dos parágrafos $1^{\circ}$ e $2^{\circ}$ acima transcritos, seja na possibilidade de reconsideração, seja na abertura da via recursal. Nessa linha, é preciso algum cuidado no manejo conjunto dos arts. 285-A e $518, \S 1^{\circ}$, do CPC, este último autorizando ao juiz negar seguimento ao recurso de apelação, caso a sentença esteja em conformidade com súmula de tribunais superiores. Não que a operação conjunta deva ser vedada. O cuidado tem a ver

\footnotetext{
${ }^{179}$ Um tipo de fraude conhecido em linguagem popular como "gato", muito recorrente na distribuição de energia elétrica, no fornecimento de água e nos serviços de televisão por assinatura (sobre a utilização do termo popular no STJ, HC 11.794/CE da Quinta Turma, Relator o Ministro Edson Vidigal)
} 
com a utilização que consolide definitivamente eventuais equívocos, principalmente na aplicação de súmulas de tribunais superiores que possam apresentar inadequação às alterações da realidade, autorizando, com novos argumentos, a abertura de debate que conduza ao cancelamento do enunciado, como nos parece possa estar ocorrendo com a Súmula 145 do STJ antes mencionada.

A certa altura afirmou-se que a possibilidade da antecipação de tutela sem o requisito de urgência em demandas repetitivas é resultado, entre outros fatores, de reformas do CPC, como a do art. 285-A. Portanto o tema relativo à zona de segurança para contemplar a acomodação de excepcionalidades há de ser constatada lá tal como aqui. Daí haver-se dedicado este tópico específico para examinar o ponto.

\subsection{A jurisprudência do juízo como requisito no art. 285-A do CPC}

Um dos requisitos impostos pela norma examinada é a existência de anteriores julgamentos pelo mesmo juízo, para compor o quadro de precedentes idênticos necessários para a prolação da sentença de improcedência prima facie. Essa particularidade suscita uma série de questionamentos, tais como: (a) quantos julgamentos anteriores são necessários? (b) havendo consenso ou, pelo menos, maioria na jurisprudência da segunda instância ou dos tribunais superiores sobre o tema, pode o magistrado julgar de plano no sentido da jurisprudência dos tribunais, mesmo que não haja, no juízo, anteriores julgados? (c) pode o juiz julgar de plano, de acordo com a sua jurisprudência, quando esta estiver em confronto com a jurisprudência pacífica (sumulada, inclusive) dos tribunais?

Como é comum nessas situações, os extremos sempre são mais fáceis de solucionar. A hipótese "c" soa absurda. Não porque, in genere, seja proibido ao juiz de primeira instância discordar de posições jurídicas dos tribunais, mas porque a sentença prima facie, fortemente motivada pelo princípio da celeridade e concebida como instrumento de gestão de repetitividades, não parece o lugar mais adequado para veicular divergências que exijam ponderações mais elaboradas, naquele contexto dialógico que pretenda agregar elementos novos ao que já está consolidado. Desde este ponto de vista, a incompatibilidade é, digamos, funcional.

Quanto ao volume de sentenças anteriores, a definição de um número é menos importante que o sentido de pacificação de entendimento que se tenha consolidado no 
juízo, a critério do próprio juiz, muito embora, pelo imperativo do plural usado na norma (casos idênticos), talvez não se deva admitir um único procedente. Seja como for, orientarse pelo plural é concessão hermenêutica à literalidade e, como tal, argumento sem maior consistência, especialmente quando o juiz está afinado com a jurisprudência já pacificada sobre o tema, embora não tenha ainda decidido nenhum caso anteriormente, hipótese em que, considerando o contexto em que se insere a norma (jurisdição de massa), e tendo em vista os seus objetivos de racionalização, parece perfeitamente adequado o julgamento prima facie já no primeiro caso distribuído ao específico juizado.

Ainda no tocante às relações com os posicionamentos dos tribunais, a possibilidade de decisão pela via do art. 285-A quando a jurisprudência não estiver pacificada (com base só na jurisprudência do juízo, portanto), é viável na medida em que a abreviação procedimental - sendo a matéria de direito - proporcionará maior rapidez nos dois sentidos, seja o da manutenção do julgado, seja no de sua reforma. E a rapidez realiza a intenção da norma.

Uma última observação necessária é a de que o legislador poderia ter aludido às súmulas dos tribunais como ponto de referência para permitir a improcedência prima facie. Esse, aliás, foi o recurso utilizado na construção do $\S 1^{\circ}$ do art. 518 do CPC. Mas não. O legislador preferiu referenciar o instituto na jurisprudência do juízo, o que abre duas perspectivas de reflexão de grande utilidade.

Em primeiro lugar, relativamente à extensão: fosse o caso de vincular sua incidência às súmulas ou mesmo à jurisprudência dominante, a norma acabaria funcionalizada aos casos de intensa repetitividade. Ao ancorá-la em precedentes locais, aumentou consideravelmente o seu espectro de incidência, incluindo aquelas outras repetitividades fora do núcleo do direito coletivo, que se aproximam, nunca é demais repetir, da jurisdição convencional. Do ponto de vista da potencialidade de expansão do instituto no interior do processo civil, a redação acaba assumindo um caráter estratégico, pois, embora nascida no contexto do direito coletivo, vem equipada para expandir-se até o limite que o amadurecimento da prática judiciária permitir, naquele sentido em que a notoriedade e as experiências pessoais do juiz possam converter a realidade exterior em facilitadores para produzir convencimento e, daí, decisões mais efetivas das demandas judiciais, tema a que se retornará quando da abordagem das máximas da experiências e dos fatos notórios. 
Outra particularidade que a referência à jurisprudência do juízo deixa à mostra está no fato de que o art. 285-A, como está redigido, constitui a primeira iniciativa do legislador em normartizar as repetitividades tão-somente no cenário da primeira instância. Ao prever o intercâmbio entre julgamentos anteriores e futuros, a técnica impulsiona o juiz para além do ambiente individual do processo, levando-o a pensar no segmento litigioso como um todo, em um tipo de reflexão, inclusive no âmbito estratégico, que de alguma maneira contribui para romper o caráter individualista do processo e da jurisdição convencional.

\section{A repetitividade e a procedência constatada prima facie}

Luiz Guilherme Marinoni e Sérgio Cruz Arenhart sintetizam, em uma breve interrogação, problema que inevitavelmente chama a atenção de todos quantos se propõem examinar o art. 285-A do CPC. Dizem eles: “(...) a norma trata apenas das sentenças de improcedência, esquecendo das ações repetitivas que conduziram a sentenças de procedência. Será que esta última situação não merece a mesma consideração da outra $?^{180}$. Os autores limitam-se à indagação, sem formular resposta. O tema, bem se vê, é justamente o que se vem desenvolvendo neste trabalho, que aponta a simetria de tratamento pela antecipação de tutela sem o requisito de urgência, decisão equivalente à sentença do ponto de vista dos efeitos práticos.

Neste tópico e no seguinte pretende-se demonstrar essa viabilidade trabalhando com os valores que se pode extrair do art. 285-A, mediante adaptação, e com a exegese ampliada do $\S 6^{\circ}$ do art. 273 do CPC (n. 11, infra).

Prosseguindo, um relevante aporte da técnica do art. 285-A à tese ora proposta está no fato de o sistema processual, a partir da vigência daquela norma, haver delimitado, no âmbito da primeira instância, que a tutela coletiva, quando veiculada em demandas individuais, exige tratamento diferenciado do que se emprega na tutela convencional. Assim como o juiz está proibido, em demandas não-repetitivas, de julgar improcedente de plano o pedido só porque já se convenceu, pela leitura da inicial, acerca da sua improcedência, também ele não pode, a priori, encarar nos mesmos termos da jurisdição convencional um pedido antecipatório em sede de demandas repetitivas. O art. 285-A do CPC significa que há algo novo na dogmática processual a merecer atenção, um valor

\footnotetext{
${ }^{180}$ MARINONI, Luiz Guilherme; ARENHART, Sérgio Cruz. Processo de conhecimento, cit., v. 2, p. 100.
} 
diferenciado no âmbito dos valores que a prática do processo reconhece. Uma especificação relevante, concreta, do princípio aberto da tempestividade posto na Constituição Federal. O exemplo da demanda em que o consumidor, sem preencher o requisito do periculum in mora, pretende o índice do Plano Bresser fala por si. Mantê-lo cativo às amarras de um processo longo e custoso não se justifica mais, justamente porque se trata de fenômeno coletivo que produz convencimento suficiente prima facie.

Em segundo lugar, o art. 285-A insere a idéia do intercâmbio de informações entre demandas diversas para o fim de convencimento e decisão em ações repetitivas. Um intercâmbio que não é só de direito, senão também de fato, uma vez que deve haver similitude fática para que possa existir identidade jurídica. A partir deste reconhecimento genérico, a proposta da antecipação de tutela exige adaptação, relativamente ao tema da verdade dos fatos da causa de pedir, que na hipótese do art. 285-A pode ser obtida formalmente, considerando o sentido da decisão de improcedência, que constitui a melhor hipótese para o réu.

A situação é diametralmente oposta no caso de antecipação de tutela, que se projeta contra a esfera jurídica do demandado, impondo-lhe restrições maiores ou menores, mas sempre restrições. Nessa linha, a adaptação necessária será trabalhada no tópico seguinte, em que se intenta identificar os meios para obter a evidência prima facie ou, pelo menos, antes do fim do ritual do procedimento, propiciando decisão antecipada.

Por fim, o terceiro aporte do art. 285-A é a reafirmação do sistema, em caráter superlativo, da idéia segundo a qual, uma vez convencido, o juiz deve decidir. Preservadas, naturalmente, as garantias constitucionais do processo, não deve protelar a decisão em nome do cumprimento do rito. Reafirmação, como dito, porque é princípio que já vigora há muito no processo civil, no instituto do julgamento antecipado. Mas reafirmação superlativa pelo caráter prima facie da sentença, o que revela o nível de influência que o princípio da tempestividade, em linha de ascendência, deve exercer sobre o processo contemporâneo.

\subsection{O tema da prova na antecipação da tutela em ações repetitivas}

Na medida em que se pretende inserir a antecipação de tutela ora proposta no contexto do $\S 6^{\circ}$ do art. 273 do CPC (n. 11.3, infra), o tema da prova aproveita-se do regime geral daquele dispositivo, já por demais conhecido e testado na teoria e na prática, 
não só pelos catorze anos de vigência, mas também pela experiência anterior, quando ainda as tutelas antecipatórias eram deferidas pela via das cautelares inominadas. Para os fins deste tópico, no entanto, a única particularidade que se quer destacar, fazendo menção ao regime da prova do art. 273, é o fato de não existir nele nenhum condicionamento relativamente a meios de prova para demonstrar os fatos em sede de antecipação de tutela. Outros desdobramentos ficam reservados para exame posterior.

Definido que cabem quaisquer meios de prova no âmbito da antecipação da tutela, convém iniciar o exame com um breve olhar sobre o contexto da formação das relações contratuais que, mais tarde, se tornarão grande parte do conjunto litigioso aqui tratado como ações repetitivas. Nesta vista geral, destaca-se aspecto que, se não é presente em todo o fenômeno das ações de massa, constitui uma constante no âmbito dos contratos de consumo $^{181}$.

Cada vez mais o empresário que opera a produção e o comércio massivo de bens e serviços utiliza-se da informalidade na instrumentalização dos contratos. Os anúncios em seções de classificados dos jornais, feitos por telefone; as compras de bens no ambiente virtual da internet; as operações bancárias entre a máquina e o consumidor, mediante códigos; os diversos negócios realizados por intermédio dos telefones móveis, que progressivamente assumem a condição de terminais de consumo. Aos poucos se abandona a prática do documento escrito e assinado, que é o paradigma da instrumentalização dos negócios na perspectiva do direito civil, e da prova, na do direito processual ${ }^{182}$. Seguramente há um cálculo de custo-benefício por trás do processo de informalização e virtualização dos contratos. Por certo o valor da palavra empenhada e a fidúcia são majoritárias nos tempos atuais. Do contrário, o custo das fraudes certamente afastaria o empresário da relação informal. Por outro lado, a economia que representa a desnecessidade do balcão para realizar as vendas, com instalações e funcionários disseminados em milhares de pontos comerciais, justifica o modelo. Qualquer empresa

\footnotetext{
${ }^{181}$ A repetitividade é idéia abrangente. Seu grande espaço de incidência são as ações massificadas - não apenas aquelas decorrentes de contratos de consumo de bens e serviços -, mas há também ações repetitivas fora do universo do direito coletivo como demonstrado neste estudo. Não obstante, a importância do consumo de massa em termos de litigiosidade justifica a abordagem que segue, centrada fundamentalmente neste fenômeno.

${ }^{182}$ Os contratos bancários de concessão de crédito, um dos grandes fatores de produção de demandas repetitivas, embora formais por exigências da legislação bancária, acabam sistematicamente sonegando a via do consumidor. O fenômeno atinge tal proporção que as ações de exibição para obviar a falta de documentos tornaram-se um setor específico da repetitividade no chamado direito bancário. Portanto, do ponto de vista de um dos pólos da relação contratual - o consumidor -, a relação com o banco não tem formalidade, o que gera conseqüências nas demandas judiciais, na mesma linha do contingente litigioso oriundo de relações não-documentadas por contratos escritos.
} 
virtualizada transforma-se, hoje em dia, em centro de negócios nacional a um custo infinitamente menor do que seria necessário para constituir pontos-de-venda pelo País afora.

Porém, embora a realidade permita concluir que a relação de custo-benefício justifica o sistema, o fato é que há um custo, que se manifesta nas específicas hipóteses em que se interpõem ruídos no canal da relação comercial, não apenas devido a fraudes - que são significativas -, mas especialmente pelos defeitos dos produtos e serviços transacionados virtualmente, pelos equívocos que levam a cadastramentos indevidos em bancos de negativação de crédito, pela entrega e cobrança de bens que não foram verdadeiramente comprados, etc.

Quando essas relações terminam no Judiciário, encontram operadores, dentre os quais o juiz, acostumados a um modelo de convicção, no âmbito das relações contratuais, pensado em termos de documento escrito (tanto melhor se público) ${ }^{183}$. Não é que haja, na lei, hierarquia de meios probatórios como regra. O que existe é uma cultura profundamente referenciada no papel escrito e assinado, cultura essa que condiciona o convencimento judicial, porque define o jeito de pensar do operador. Então, quando chega ao Judiciário a conflituosidade de massa, informal nos seus registros, o sistema comporta-se como quem sente falta de prova, e responde abrindo aos contendores todos os espaços que a ritualística oferece para serem demonstrados os fatos em juízo.

Na verdade, houve duas alterações, que já se pode afirmar estabelecidas no mundo do comércio massificado, e que pressionam o processo por ajustar suas referências sobre a maneira de realizar-se o convencimento judicial neste setor, bem como sobre a natureza do convencimento em termos de profundidade.

A primeira alteração está em que a menor formalidade - ou até mesmo a total informalidade -, enquanto fenômeno da economia massificada, atua como elemento

\footnotetext{
${ }^{183}$ A Lei 11.419, de 19 de dezembro de 2006, instituiu o chamado processo digital e alterou dispositivos do CPC, com o fim de adaptar o processo aos meios digitais de registro e comunicação. Especificamente quanto ao valor probante dos documentos, a reforma incluiu no art. 365 do CPC os atuais incisos V e VI, em que o legislador distingue os "documentos digitalizados" e os "documentos digitais". Aqueles, existentes no mundo físico, transportados para o mundo digital e de lá reproduzidos, cujo regime de valor probante é fundamentalmente o mesmo das cópias reprográficas (inc. V). Já os "documentos digitais", que se formam no meio digital e por isso mais importam para estudo das relações virtualizadas, só têm valor probante equiparável ao original se autenticados pelo responsável do banco de dados emitente (inc. VI). A necessidade dessa autenticação inviabiliza-se, na prática, justamente porque o objetivo das relações virtualizadas é realizarem-se sem o contato entre as partes. Outra vantagem trazida pela lei, como a assinatura digital, constitui sofisticado modelo de garantia, cujo custo e o caráter efêmero dos contratos virtuais em relações massificadas, não lhes permite incorporar. De modo que a legislação mencionada não altera o cenário que se desenha neste capítulo.
} 
dificultador para um sistema judiciário que se acostumou a pensar e convencer-se em outros patamares. A segunda vem de que esses contratos informais são produzidos em série, apresentando as mesmas características gerais - obedecendo a um padrão - o que autoriza a recorrer, para defini-los, ao mesmo adjetivo utilizado no art. 285-A do CPC: são contratos idênticos, ou, mais genericamente, práticas contratuais idênticas. Trata-se de característica que acaba assumindo a condição de facilitador a ser capturado pelo sistema processual, em contrapartida das dificuldades que a falta de formalidade acarreta no ambiente do processo.

Prosseguindo, algum resultado já se produziu em vista dos fenômenos próprios da massificação, em termos de prova no processo. O Código do Consumidor, por exemplo, oferece chance de adaptação significativa na inversão do ônus da prova (art. $6^{\circ}$, inc. VIII). Mas essa providência não toca senão a superfície do problema e, bem examinada, apenas reafirma o modelo tradicional de convencimento judicial, que se disse inadequada para a realidade dos contratos de massa. Inverter o ônus da prova no sistema da ordinariedade exige o aviso prévio àquele contra quem se opera a inversão, para que possa ele realizar a prova contrária ${ }^{184}$. Inverter significa reafirmar a ânsia do sistema por uma prova mais completa, com a nota de que, se ela não vier, o convencimento será orientado em favor do demandante. Observa-se, então, que a anatomia das relações de massa, no âmbito das provas, foi absorvida pelo sistema não exatamente para propiciar decisão com maior rapidez, mas, sim, para propiciar a utilização de uma regra formal de convencimento ínsita na inversão do ônus probatório - que, ao contrário de abreviar o rito processual relativamente à produção de resultados práticos, implica o seu retardamento.

Ao inverter o ônus da prova, é como se o juiz dissesse: minha intenção é convencer-me substancialmente, mas desde já declaro que, se chegarmos ao fim do processo sem que eu esteja substancialmente convencido, minha decisão será em favor do autor. Ora, nos litígios de massa o que ocorre é que o juiz já está substancialmente convencido, em regra, muito antes do fim do rito processual, não raro prima facie. Portanto o debate sobre a prova no âmbito das demandas de massa exige reconhecer a alteração que a realidade deve produzir no regime de convencimento. Ou melhor, na identificação, dentro do sistema processual, da possibilidade de converter em decisão o sentimento que o

\footnotetext{
${ }^{184}$ Nesse sentido, Carlos Roberto Barbosa Moreira, Notas sobre a inversão do ônus da prova em benefício do consumidor. Revista de Direito do Consumidor, São Paulo, n. 22, p. 136-137, abr./jun. 1997.
} 
juiz invariavelmente experimenta nas demandas repetitivas, que lhe indica qual será a decisão final do novo caso que lhe chega às mãos.

Parece-nos que essa alteração passa por duas compreensões. Uma relativa a saber se as razões pelas quais o juiz assim se convence são aceitáveis no padrão de convencimento judicial. É como perguntar: é possível admitir como válido, processualmente, esse tipo de convencimento? Trata-se de exame próprio do instituto da prova, a ser examinado no tópico seguinte. O segundo aspecto relevante diz respeito ao fato de que a medida da suficiência do convencimento judicial comporta gradações no âmbito do processo, motivadas por contingências diversas.

Uma dessas contingências reporta-se à decisão que as partes tomam, na fase préprocessual, acerca de como documentar sua relação. Os setores que se valem da escritura pública como documento-padrão, tal como as operações de compra e venda de imóveis, induzem a um tipo de verdade processual com um nível acentuado de detalhamento, tendencialmente mais próximo do que se costuma denominar verdade real. É este o norte que deve orientar o juiz ao pensar e ordenar a produção da prova no processo e, principalmente, ao limitar até onde deve estender a medida da certeza histórica, ou seja, a sua convicção. Já um outro setor que abandone aquele ritual de documentação, posicionando-se no outro extremo da informalidade, induzirá a um tipo de convicção menos intensa, que tendencialmente deve se satisfazer com uma verdade mais aproximada do perfil médio como aquelas relações contratuais geralmente se apresentam ${ }^{185}$.

Uma vez estabelecido o padrão de verdade suficiente, não se trata de aplicá-lo só na sentença, após a oportunização de ampla coleta de provas. Por isso se refere que as

\footnotetext{
${ }^{185}$ Sobre o tema probatório, vale referir a lição de Carlo Furno, quando sustenta que o objeto da prova não é a verdade empírica propriamente, senão a verdade judicial, resultado de um esforço de reconstituição histórica que culmina no convencimento do juiz, e que nos parece correto identificar como a verdade possível, destacando assim o conjunto de vicissitudes que atuam sobre a complexa dinâmica do processo. Segundo o jurista, o sucesso maior ou menor da verdade possível imputa-se parcialmente à responsabilidade das partes, tanto no cumprimento de suas atividades probatórias no processo, quanto ao que trazem como prova constituída na fase pré-processual (FURNO, Carlos. Teoria de la prueba legal. Madrid: Revista de Derecho Privado, 1954. p. 20-29). A conexão entre a verdade possível, a responsabilidade das partes na construção dessa verdade e a natureza da prova que as mesmas partes produziram na fase pré-processual, justifica afirmar que a verdade judicial haverá de ter a sua medida informada pelo tipo de formalização que as partes construíram. Ou seja: o grau de verdade judicial a ser perseguido no processo é um pouco estabelecido pelo grau de formalidade que as partes deliberaram construir. Essa medida, quando se apresenta extensivamente em um setor da economia, não deve ser encarada, contudo, como providência subsidiária, para ser acionada só na sentença, depois de abrir-se ampla possibilidade de produção de provas, senão desde o início do processo, como única forma de ajustar - nas ações de massa, é bom que fique mais uma vez registrado - a jurisdição aos contornos do fenômeno social que, ao ingressar no processo, reclama adequação. $\mathrm{Na}$ visão prática que a narrativa acima proporciona, é a maneira de evitar que a utilização de um ritual construído para proporcionar a decisão justa, acabe convertendo-se em instrumento de injustiça.
} 
demandas de massa exigem um regime específico de convencimento, diferente das demandas convencionais. E foi nesse sentido que se falou, acima, de setores do mercado (o dos negócios imobiliários, baseados no documento público, e os de massa, informais), pois, se não há como estabelecer um regime de convencimento para cada demanda individualmente, é possível fazê-lo para o setor das demandas repetitivas, tal como, de alguma maneira, o art. 285-A do CPC sinaliza possível.

E assim, em demanda de um consumidor negativado no serviço de proteção ao crédito por alegado equívoco do fornecedor, que afirmadamente recebeu a mensalidade e não a processou em seu sistema de dados, por exemplo, não parece adequado exigir mais do que a palavra desse consumidor para a decisão. Sobretudo se é notório que, no fechamento daquele tipo de negócio, o mercado não exige mais do que a palavra dele e, por outro lado, se, no específico juízo a que foi distribuída a demanda, o mesmo fornecedor esteve várias vezes envolvido em demandas pelo mesmo tipo de equívoco.

Outra observação necessária é a de que o fenômeno das ações repetitivas e, dentro destas, o das ações de massa, não se limita ao universo dos contratos de consumo de bens e serviços. Não obstante, como é justamente neste setor que o problema probatório se mostra mais intenso, pareceu adequado referenciar nele as considerações gerais sobre a prova.

Finalizando, a síntese que se pode registrar desdobra-se em duas partes: primeiro a de que não há limitações quanto a meios de prova no âmbito das antecipações de tutela em demandas repetitivas; segundo, a de que há uma realidade peculiar no universo das relações de massa, pelo menos no âmbito daquelas que se referem às relações de consumo, a definir um regime de convencimento adaptado, considerando que a convicção suficiente do juiz para decidir a causa forma-se geralmente antes do fim do ritual convencional do processo, não raro prima facie. Saber se essa convicção pode valer como verdade judicial é objeto do próximo capítulo.

\subsection{Fatos notórios e máximas da experiência}

Como destinatário das provas, cuja finalidade última é produzir convencimento acerca dos fatos, o juiz é livre para valorá-las e no atual estágio da ciência do processo tem considerável poder de determinação ex officio, quando entenda necessário algum aporte probatório complementar àquele que as partes tomaram a iniciativa de produzir. Mas toda essa liberdade tem um limite muito precisamente definido, que é o acervo constante dos 
autos (art. 131 do CPC), significando que o juiz não poderá, como regra, recorrer a informações extra-autos. Trata-se, em um primeiro plano, da preservação do contraditório, pois as provas oficialmente produzidas no processo o foram com a participação das partes, que então tiveram como exercer o direito de crítica e de contraprova.

$\mathrm{O}$ veto se estende inclusive aos fatos de que o juiz tenha tomado conhecimento particularmente, fruto da observação direta (como o acidente de trânsito que casualmente presenciou de sua janela” $\left.{ }^{186}\right)$, pois, se admitidos, ele atuaria a um só tempo como juiz e testemunha, em prejuízo da imparcialidade, já que, humanamente, a versão pessoal tende a afastar outras versões que não se compatibilizem com ela. E então a única verdade seria a verdade do "juiz-testemunha"187. Segundo Friedrich Stein, "La verdadera causa de la referida prohibición (...) radica primaremente en la impossibilidad sociológica de enjuiciar imparcialmente la propria testificación” ${ }^{188}$.

Há, no entanto, duas exceções ao princípio, que são os fatos notórios e as denominadas máximas da experiência ${ }^{189}$, conforme art. 334, I, do CPC, segundo o qual “Não dependem de prova os fatos: (...) notórios”, e art. 335 do mesmo Código, ao regular que "Em falta de normas jurídicas particulares, o juiz aplicará as regras da experiência comum, subministradas pela observação do que ordinariamente acontece, e as regras da experiência técnica, ressalvado, quanto a esta, a prova pericial”.

Desde já cabe dizer que o referido artigo 335 não se destina a incidir apenas quando houver lacunas na lei, como pode parecer a um olhar menos atento, especialmente na parte em que refere a falta de normas particulares. É unânime em sede doutrinária o entendimento de que essas normas particulares são as presunções legais. Ou seja, o juiz só fica proibido de valorar as provas de acordo com as máximas da experiência se houver

\footnotetext{
${ }^{186}$ FABRÍCIO, Adroaldo Furtado. Fatos notórios e máximas da experiência. In: MORAES, Maurício Zanóide de (Org). Estudos em Homenagem à Professora Ada Pellegrini Grinover. São Paulo: DPJ Ed. 2005. p. 432.

${ }^{187}$ Francisco Rosito detalha as razões da inviabilidade nos seguintes termos: "Impende destacar que a proibição da utilização da ciência privada do juiz encontra fundamento em várias considerações. A primeira delas consiste na impessoalidade do juiz, caracterizada por uma situação de indiferença, seja perante a singularidade das partes, seja perante a sua própria singularidade. O segundo fundamento seria a incompatibilidade psicológica entre a função do juiz e aquela de testemunha, o terceiro fundamento, considerado o mais relevante, constitui o necessário prestígio da garantia do contraditório: o juiz não pode afirmar a existência ou a inexistência do fato a provar, na falta de elementos de prova obtidos no âmbito do contraditório processual. $O$ quarto fundamento está na necessidade de garantir às partes o controle da decisão e de evitar decisões suspeitas de imparcialidade”. ROSITO, Francisco. Direito probatório: as máximas de experiência em juízo. Porto Alegre: Livr. do Advogado, 2007. p. 51.

${ }^{188}$ STEIN, Friedrich. El conocimiento privado del juez. Tradução de Andrés de La Oliva Santos. Bogotá: Editorial Temis, 1988. p. 4.

${ }^{189}$ Nesse sentido, FABRÍCIO, Adroaldo Furtado. Fatos notórios e máximas da experiência, cit., p. 432, e ROSITO, Francisco. Direito probatório: as máximas de experiência em juízo, cit., p. 51.
} 
norma de interpretação legal que lhe obrigue no sentido de uma conclusão específica. $O$ próprio posicionamento da norma no plano do $\mathrm{CPC}$, em compartimento dedicado às “Disposições Gerais” sobre a prova dá a medida de sua incidência ${ }^{190}$.

Mas sobre as máximas da experiência voltaremos a tratar adiante, pois o mais importante é partir do estudo dos fatos notórios.

Não há consenso doutrinário acerca da definição dos fatos notórios, conforme observa Moacyr Amaral Santos ${ }^{191}$, o que exige trabalhar por aproximação, identificando contornos que, no conjunto, permitem visualizar o instituto com bom nível de precisão, considerando, inclusive, os objetivos de seu exame neste trabalho.

Os ensinamentos elementares procuram trabalhar com exemplos e, ao fazê-lo, com os exemplos mais extremados. Dessa forma, se, por um lado, alcançam definição segura, por outro, posicionam o instituto em um espaço algo distante, afastando-o do quotidiano com a conseqüente perda de utilidade. Em passagem a que inseriu um certo sabor de estilo literário, o clássico Friedrich Stein, ainda no século XIX, atentava para este pormenor de grande relevância até hoje: "Pero suplico a mis lectores que hagan todo lo possible para no imaginarse como ejemplos de hechos notórios (...) la muerte de Carlomagno o el descubrimiento de America. Es un error conocido de algunas teorías jurídicas ir creciendo a partir de um determinado paradigma y acoplar-se a él (...)”192. Esse superdimensionamento acaba por sugerir que são fatos de tal maneira conhecidos de todos, que praticamente se tornam desnecessários no âmbito do processo, porque jamais alguém ira, seriamente, controvertê-los. Outro perigo de perda de significado é definir pela função, ou seja, notório é o que não exige prova, tautologia que também mereceu o alerta de Stein $^{193}$.

Um critério de efetiva utilidade é o que identifica como notório o fato de que qualquer pessoa possa tomar conhecimento utilizando meios normais de informação. Em suma, é o fato que se tornou público, definição que exige as seguintes notas explicativas complementares: (a) a publicidade que os caracteriza é tanto aquela que se espraia pela comunidade em geral, como a que fica contida em círculos mais reduzidos. Assim, é

\footnotetext{
${ }^{190}$ Nesse sentido GRECO FILHO, Vicente. Direito processual civil brasileiro. 19. ed. São Paulo: Saraiva, 2008. v. 2, p. 212-213, FABRÍCIO, Adroaldo Furtado. Fatos notórios e máximas da experiência, cit., p. 435, e ROSITO, Francisco. Direito probatório: as máximas de experiência em juízo, cit., p. 132-133.

${ }^{191}$ SANTOS, Moacyr Amaral. Comentários ao Código de Processo Civil. 4. ed. Rio de Janeiro: Forense, 1986. v. 4, p. 36.

${ }^{192}$ STEIN, Friedrich. El conocimiento privado del juez, cit., p. 169.

${ }^{193}$ STEIN, Friedrich. El conocimiento privado del juez, cit., p. 172.
} 
notório o incêndio de um edifício nos limites da cidade em que ocorreu, por exemplo. Bem por isso Vicente Greco Filho salienta que "não há necessidade que a notoriedade seja absoluta, basta que seja local ou regional" , ou mesmo, arremata, restrita ao círculo específico do pessoal do foro ${ }^{194}$; (b) a notoriedade pode ser afirmada mesmo quando quem afirma não presenciou o fato, inclusive porque há fatos notórios acontecidos em passado mais ou menos distante como a tomada do poder na chamada Revolução de 1964, quando os militares governaram o Brasil por mais de duas décadas; (c) a notoriedade é relativa e pode desaparecer com o tempo: o que ontem era notório, pode deixar de sê-lo no futuro ${ }^{195}$; (d) não se exige que o fato notório seja previamente conhecido pelo juiz, que inclusive pode tomar conhecimento dele no interior de algum processo: “o juiz pode ignorar a época em que se faz a colheita de café no Estado de São Paulo, mas nem por isso essa época deixa de ser notória, bastando-lhe, para conhecê-la, consultar qualquer calendário especializado ou qualquer agricultor ou comerciante de café" ${ }^{196}$.

Nesta última observação destaca-se característica marcante da notoriedade aproveitável no processo: trata-se de fato acerca do qual o conhecimento distribuído entre muitas pessoas acaba fixando a existência e os contornos com tonalidade objetiva, e por isso o fato se deixa reconhecer não a partir da impressão sensorial do juiz ou da pessoa que o afirma ${ }^{197}$. É nesses termos que a realidade objetiva pode ser trazida para dentro do processo, e nele utilizada, sem macular a imparcialidade ou o contraditório. Para dizer-se que a colheita do café no Estado de São Paulo se realiza em determinada época do ano, não é preciso recorrer a uma versão pessoal, a um juízo subjetivo, ao contrário da narrativa do acidente visto da janela. Também não há um juízo sensorial quando se afirma que "Existe uma avalancha de ações” no Foro de Porto Alegre e região metropolitana, "versando sobre a venda de almofadas vibratórias elou térmicas fabricadas pela ré ${ }^{, 198}$. Trata-se de

\footnotetext{
${ }^{194}$ GRECO FILHO, Vicente. Direito processual civil brasileiro, cit., v. 2, p. 197.

${ }^{195}$ Segundo Friedrich Stein, "La experiencia enseña, antes bien, que hoy es notorio el hecho que ayer no lo era y que dentro de semanas o años dejará de serlo. Hoy v. gr., todo el mundo sabe que el emperador Guillermo II nasció el 27 de enero de 1859, mientras que seguramente muy pocos sabrán que el príncipe heredero alemán nació el 6 de mayo de 1882. Hace veinte años el primer hecho aún no era notorio, y en el futuro, cuando suba al trono el príncipe heredero, será notorio el segundo." STEIN, Friedrich. El conocimiento privado del juez, cit., p. 171.

${ }^{196}$ SANTOS, Moacyr Amaral. Comentários ao Código de Processo Civil, cit., v. 4, p. 37.

${ }^{197}$ Comentando o art. $514^{\circ}$ do CPC português, cujo caput dispensa de prova os fatos notórios, Abílio Neto destaca essa particularidade: "Um facto é notório quando o juiz o conhece (...) sem necessitar de recorrer a operações lógicas e cognitivas, nem a juízos presuntivos”. NETO, Abílio. Código de Processo Civil anotado. 14. ed. atual. Lisboa: Ediforum, 1997.

${ }^{198}$ Decisão lançada no processo n.3.07.0040595-8, do Juizado Especial Cível do Foro Regional da Tristeza em Porto Alegre. Tribunal de Justiça do Estado do Rio Grande do Sul. Disponível em: <www.tj.rs.gov.br>. Acesso em: 14 jan. 2009.
} 
uma constatação objetiva que qualquer pessoa pode obter utilizando os meios normais de informação (acesso ao banco de dados da justiça), o que se ajusta ao pensamento de Barbosa Moreira, para quem um requisito da notoriedade é "la possibilidad que culquiera tenga de, utilizando los médios normales de información, llegar al conocimiento del hecho" ${ }^{199}$.

A esta altura, já se tem o bastante para um nível de compreensão adequado, visualizando as duas linhas mestras do instituto, que são o traço objetivo, acima destacado, e a viabilidade de obter-se a informação por vias normais. Ou seja, não basta que haja acesso fácil a um depoimento constante em determinados autos de processo, que é público, para que o conteúdo do depoimento acerca de como se deu um acidente torne notória a responsabilidade afirmada pela testemunha, ou para que torne notório o fato de que tal semáforo estava em vermelho no momento da colisão. Mas será notória, sem dúvida, a existência do depoimento naquele processo, na medida em que esta última é informação, além de pública, objetiva, no sentido de não depender, para revelar-se, de um juízo pessoal de quem afirma.

Fala-se em notoriedade judicial ${ }^{200}$, nomenclatura que sugere a existência de uma categoria diferenciada. E realmente existiria diferença, se admitido que o juiz se valesse do conteúdo do depoimento da testemunha, na hipótese do parágrafo anterior, para utilizar na sentença de outro processo a narrativa sobre a posição do semáforo como elemento de prova, sem que as partes tivessem podido inteirar-se e controverter sobre o mencionado depoimento. Isso não é possível entre nós porque não se trata de uma informação objetiva e sim da impressão pessoal de um observador do fato ${ }^{201}$. Mas quanto ao demais, quanto àquilo que o juiz colhe no espaço público do foro, não há diferença de gênero e espécie, de modo a compor uma categoria à parte. Trata-se de fato notório como todos os outros, muito embora o uso da locução notoriedade judicial seja valioso, em nosso entendimento,

\footnotetext{
${ }^{199}$ MOREIRA, José Carlos Barbosa. Prueba y motivación de la sentencia In: Temas de direito processual: oitava série. São Paulo: Saraiva, 2004. p. 113.

${ }^{200}$ Conforme MICHELI, Gian Antonio. La carga de la prueba. Tradução Santiago Santis Meleno. Buenos Aires: EJEA, 1961. p. 118-120.

${ }^{201}$ Vale referir que se o depoimento vem trasladado para os autos e é controvertido pelas partes, ele se define como prova emprestada, categoria diversa do fato notório. $\mathrm{O}$ valor da prova emprestada varia, dependendo de ter(em) a(s) parte(s) participado do processo em que ela foi produzida originalmente, ou não. Nessa linha, pode figurar como importante elemento de conviçcão no âmbito das demandas repetitivas, considerando que, nestas, é muito comum o fenômeno de várias ações contra um mesmo réu. SILVA, Ovídio A. Baptista da. Sobre o valor da prova emprestada. 5. ed. São Paulo: Ed. Revista dos Tribunais, 2000. p. 360-361.
} 
porque permite reconhecer de plano que também podem ser notórios os fatos compartilhados no ambiente do foro.

A função dos fatos notórios é variada no convencimento judicial. Podem servir como fato principal, quando, por exemplo, na demanda indenizatória contra determinada companhia petrolífera, a responsabilidade dela se define pelo vazamento de um oleoduto, acontecimento que se tornou notório na região ou mesmo no país. E, se sobrevierem demandas indenizatórias repetitivas, como é comum em situações desse tipo, a partir do processamento de um certo número dessas causas, não só o elemento mais geral (o vazamento, em si), mas até características específicas (como o dia exato do vazamento, o perímetro geográfico no qual o óleo se derramou, o tipo de doenças que causa, etc), acabam atingindo notoriedade judicial, facilitando o trabalho da justiça.

O fato notório pode, também, significar indício (é notório que a atriz assassinada vivia maritalmente com o acusado do crime $^{202}$ ), ou mesmo constituir premissa para a construção de presunções comuns, como na seguinte passagem de julgamento no Tribunal de Justiça do Rio Grande do Sul acerca de disputa entre acionistas e determinada companhia telefônica: "Não obstante o acórdão tenha condenado a agravada a emitir ações, fls. 84-93, é fato notório (existem centenas de milhares de ações sobre o tema) que a agravada não as subscreve, encaminhando a solução para a via indenizatória." ${ }^{203}$. Ou seja, porque é notório o propósito de descumprimento, o Tribunal atalhou, convertendo de pronto a obrigação em indenizatória.

Prosseguindo, diferentemente da categoria dos fatos notórios, as máximas da experiência não são fatos, mas conclusões que se retiram de acontecimentos reiterados, sempre repetindo uma mesma constante, que se transforma em máxima ${ }^{204}$. José Carlos Barbosa Moreira arrola vários exemplos que facilitam a compreensão: (a) as águas paradas proliferam mosquitos; (b) a gestação humana dura nove meses, em regra; (c) as pessoas vão à praia mais no verão que no inverno; (c) a escassez aumenta o preço das mercadorias. E prossegue o jurista indicando os traços conceituais em comparação com os fatos

\footnotetext{
${ }^{202}$ Neste ponto, em que se refere o mundo das personalidades públicas, calha lembrar a importância dos meios de comunicação para generalizar informações. Friedrich Stein assinalava que a maioria dos fatos notórios assume essas características não por terem sido presenciados por muitos, mas pela divulgação; e destacava a imprensa como o grande veículo de formação de fatos notórios. STEIN, Friedrich. El conocimiento privado del juez, cit., p. 174-175.

${ }^{203}$ Agravo Interno n. 70027508043, 20 . Câmara Cível do Tribunal de Justiça do Rio Grande do Sul, Relator o Desembargador José Aquino Flores de Camargo.

${ }^{204}$ Excepcionalmente, algumas máximas científicas constroem-se mediante uma única demonstração experimental. Mas a regra no âmbito das máximas de experiência é elas se formarem como resultado de reiterações.
} 
notórios: "Ao lado desses fatos, alinham-se precisamente as chamadas 'regras de experiência' que deles se distinguem por seu caráter de generalidade $e$ abstração: não se trata agora de acontecimentos singulares, mas de noções que refletem o reiterado perpassar de uma série de acontecimentos semelhantes, autorizando, mediante raciocínio indutivo, a convicção de que, se assim costumam apresentar-se as coisas, também assim devem elas, em igualdade de circunstâncias, apresentar-se no futuro ${ }^{205}$.

Também aqui há particularidades que precisam ser delimitadas. Em primeiro lugar, a circunstância de que pode haver repetição de acontecimentos congêneres sem que deles se retire mais que um "juízo plural”. Ou seja: da constatação que dez testemunhas mentiram ao depor na demanda de um parente comum, não se retira a regra segundo a qual as pessoas mentem quando depõem em processos envolvendo parentes ${ }^{206}$. Portanto é requisito da máxima de experiência que os fatos autorizem extrair uma constante que se projeta ao futuro, como indicado na transcrição supra. Outra característica está em que, para recorrer ao instituto, não é preciso que o juiz tenha pessoalmente vivenciado os fatos ou parte dos fatos que, repetindo-se, deram origem à regra de experiência. Isso define um traço muito relevante, que é a inexistência de impressões pessoais - juízos - na formulação da máxima. Como foi explicado no início, uma das razões do veto a que o magistrado traga para o processo informações de fora dos autos é o risco de perda da imparcialidade que a pessoalização pode produzir. Mas isso não se dá nesse caso, porque as máximas da experiência são imunes às impressões pessoais do juiz que recorre a elas. E, não estando contaminadas pelo subjetivismo, podem ser amplamente utilizadas no processo ${ }^{207}$.

Do ponto de vista da função, servem para três propósitos: (a) para definir fatos probandos: no exemplo acima o magistrado afirmou, pela experiência vivenciada por ele e por outros juízes em milhares de ações em que se repetiu o mesmo comportamento de determinada empresa, que naquele caso ela certamente tornaria a descumprir a obrigação

\footnotetext{
${ }^{205}$ MOREIRA, José Carlos Barbosa. Regras da experiência e conceitos juridicamente indeterminados. Revista Forense, Rio de Janeiro, ano, v. 261, p. 13, jan/mar 1978. O conceito clássico é o de Friedrich Stein: "son definiciones o juicios hipotéticos de contenido general, desligados de los hechos concretos que se juzgan en el proceso, procedentes de la experiência, pero independientes de los casos particulares de cuya observación se han inducido y que, por encima, de esos casos, pretenden tener validez para otros nuevos. STEIN, Friedrich. El conocimiento privado del juez, cit., p. 27.

${ }^{206} \mathrm{O}$ exemplo é de STEIN, Friedrich. El conocimiento privado del juez, cit., p. 25.

${ }^{207}$ Cabe ressalvar que nenhuma atividade intelectual pode ser desconectada totalmente do subjetivismo do agente. Sempre o juiz colocará alguma coisa pessoal na operação das máximas da experiência e dos fatos notórios. A própria escolha, entre vários fatos e várias máximas, de uma ou outra, importa a pessoalização e uma certa dose de subjetivismo. Portanto, ao descrever os institutos valendo-se das categorias subjetivo/objetivo, se está na verdade trabalhando com conceitos que, não sendo absolutos, exercem papel decisivo no direito, pois correspondem a consensos pressupostos em nossa cultura no momento histórico atual, sobretudo entre os operadores do direito.
} 
de fazer, razão por que imputou diretamente a responsabilização pecuniária. O fato probando era justamente o sentido do agir da demandada; (b) funcionar como baliza para valorar a prova produzida nos autos ${ }^{208}$ : supondo que duas testemunhas, uma das quais daltônica, prestem depoimento sobre a cor do veículo que causou o acidente, o juiz naturalmente preferirá o depoimento da testemunha de visão normal, com apoio em corriqueira regra de experiência" ${ }^{209}$. (c) para auxiliar na tarefa de subsunção da lei ao caso concreto, quando as normas contêm conceitos jurídicos indeterminados, tais como abuso de poder ou boa-fé.

Máximas da experiência e fatos notórios relacionam-se e, às vezes, são confundidos. Afirmar que é notório que a mãe sofre com a morte de um filho constitui uma máxima da experiência. Aliás, uma máxima notória, pois a característica da notoriedade não é exclusiva de fatos. E aqui importa relembrar, entre parênteses, que são admissíveis no processo quaisquer máximas, mesmo as que não são notórias.

No ambiente das ações repetitivas, como foi salientado anteriormente, esses dois institutos assumem vigor renovado, justamente porque, em sua ontologia, têm muito a ver com repetições, notadamente as máximas da experiência. Quanto aos fatos notórios, embora a repetitividade não lhes componha o conceito, exerce influência indireta na sua gênese pelo tanto que significa na divulgação de fatos. Nessa linha, vale lembrar que Friedrich Stein atribuiu a formação da notoriedade a duas causas: o modo como acontecem os fatos - o rei que entra na cidade e todos vêem - e à sua divulgação, sendo esta segunda hipótese, com a qual, parece-nos, a repetitividade interage, a mais importante do ponto de vista quantitativo no entender do jurista. ${ }^{210}$

A utilidade dos institutos ora examinados no manejo da técnica preconizada neste trabalho é evidente. Os exemplos formulados o comprovam. Várias demandas já examinadas pelo juiz contra um mesmo banco, versando sobre o Plano Collor I, o

\footnotetext{
${ }^{208}$ Como tratado no n. 10.1, supra, as relações virtualizadas não produzem documentações que atendam ao padrão de exigência tradicional da justiça. A reforma da Lei 11.419/2006, que inseriu os incisos V e VI no art. 365 do CPC, não alterou significativamente essa realidade. De modo que a específica função das máximas de experiência na apuração do valor dos elementos de prova tende a obviar soluções para esse intrincado problema que enfrenta a jurisdição em face da crescente e inevitável informalidade das relações contratuais massificadas (desde que, ao manejá-las, o juiz traduza o como as coisas geralmente acontecem no ambiente virtual). Para um detalhado exame sobre o contraste entre a documentação do mundo virtual e as exigências da prova no processo civil, vide YARSHELL, Flávio Luiz; MATEUCCI, Carlos Roberto F.; PINTO, Luís Otávio Camargo. Eficácia probatória do documento eletrônico. Repertório IOB de Jurisprudência, n. 21, p. 489-493, 1999.

${ }^{209}$ MOREIRA, José Carlos Barbosa. Regras da experiência e conceitos juridicamente indeterminados, cit., p. 14.

${ }^{210}$ STEIN, Friedrich. El conocimiento privado del juez, cit., p. 173-175.
} 
autorizam a ter como certa, prima facie, a alegação do autor sobre a inadequada correção de seus depósitos, à medida que o mesmo comportamento se tenha repetido nas demandas anteriores. A verificação sistemática em ações precedentes, de que a prática comercial de uma seguradora é exigir quitação geral quando há pagamento parcial, constitui o bastante para que seja de plano admitida como verdadeira a afirmação do demandado nesse mesmo sentido. Outro exemplo que se pode indicar, parte do fato real das ações de exibição repetitivas contra instituições financeiras, que recusam fornecer cópias dos contratos aos clientes. Na nova ação exibitória que lhe chega hoje, o juiz não precisa mais que a evidência da repetição para admitir, de plano, como verdadeira a versão do autor acerca da negativa de fornecimento de cópia, se o faz contra um banco várias vezes demandado pela mesma causa.

O rol de passageiros que estavam no avião que protagonizou o maior acidente aéreo do Brasil, no ano de 2007, e o fato de que todos morreram, são notórios, assim como é certo que a perda de uma filha ou do pai provocam dano moral indenizável, porque essa é uma constante em tais situações (máxima da experiência). A viabilidade de convencimento prima facie em casos assim é paradigmática, tanto sobre a responsabilidade da empresa aérea, como sobre aquele mínimo de indenização do dano moral, por exemplo, abaixo do qual se sabe, desde o início, não há nenhum risco de a sentença futura fixar ${ }^{211}$.

No âmbito dos chamados Planos de Saúde, houve época em que praticamente a totalidade das empresas limitava o tempo de internação hospitalar. Até que sobreveio a Súmula 302 do STJ, com o seguinte enunciado: "É abusiva a cláusula contratual de plano de saúde que limita no tempo a internação hospitalar do segurado”. Suponhamos, partindo daí, que um segurado com excelentes condições financeiras, internado em hospital privado, venha a ter cortada a cobertura dos custos de hospitalização por suposto limite temporal. Imaginemos, ainda, que o episódio repita conduta reiterada da mesma empresa, conhecida pelo juiz em demandas anteriores. Examinado o caso em um contexto convencional do processo, o fato de o segurado gozar de ótima saúde financeira, proibiria o deferimento pela via da urgência, não obstante a evidência do direito.

\footnotetext{
${ }^{211}$ A rigor, no caso deste exemplo seriam dispensáveis até mesmo as repetições em demandas anteriores, tamanho o conjunto de fatos notórios. Por outro lado, a responsabilidade do transportador é objetiva. Conjugando tudo, há evidência prima facie pelo menos em relação àquele mínimo abaixo do qual não há risco de fixar-se o valor do dano moral, por exemplo, sem nenhuma necessidade de dilação probatória. A única zona viável de ser controvertida seria a condição de filho ou pai, conforme a formulação do exemplo, com base na alegação da falsidade da certidão de nascimento. Mas a hipótese é de tal maneira excepcional que não merece ser considerada. De modo que parece completamente viável o deferimento prima facie de antecipação de tutela, mesmo sem o requisito da urgência, para pagamento de indenização parcial.
} 
Seguindo no exemplo do paciente interno no hospital, para ser exaustivo no teste de qualidade do convencimento prima facie, pode-se cogitar, a título ilustrativo, da eventual falsidade do contrato manejado pelo autor. Essa hipótese - e as outras tantas que cabem quando se permite abrir espaço para tais ordens de indagação -, estaria em si mesma a comprovar que jamais o convencimento prima facie da procedência basta para uma decisão sem outros requisitos excepcionais, sobretudo a urgência. Vale dizer, não poderia haver convencimento prima facie de procedência.

Aqui entram duas considerações de grande relevância. Primeiro a de que o sentimento estatístico ${ }^{212}$, oriundo das demandas anteriores vivenciadas pelo próprio juiz ou disponíveis no sistema de informações do Judiciário, não autoriza a crer na possibilidade do falso, se a regra da experiência haurida no conjunto dos outros casos idênticos não apontar nessa direção. Em segundo lugar, o caso se insere naquele contexto mercadológico de informalidades de que se falou linhas acima, determinante de um tipo de convencimento judicial que guarde proporcionalidade com a forma como se comporta o específico segmento em que se insere a relação das partes. Por aí, a só apresentação em juízo do cartão magnético fornecido pela empresa de saúde privada seja talvez suficiente, porque é o documento maior da relação entre as partes, aquele que realmente desempenha um papel nos atos de execução do contrato. Tudo isso equalizado pela absorção dos riscos que o agente econômico já realizou, e pelo risco próprio da atividade jurisdicional, que não se pode deter em um referencial de exceção (a idéia do contrato falso) quando a realidade não lhe deixa espaço para dúvidas, em um contexto de como as coisas ordinariamente acontecem.

De modo que as ações repetitivas autorizam enxergar um verdadeiro segmento litigioso em que o juiz pode convencer-se integralmente (suficientemente) sobre a solução definitiva que deva dar ao caso, seja no início da demanda, seja antes do fim do ritual do processo. Não pode, entretanto, sentenciar em definitivo nessa hora, mas pode antecipar tutela.

Voltando um pouco atrás na linha condutora do estudo, observa-se a conexão deste tópico com o ponto em que se afirmou que um dos argumentos em prol da existência da antecipação de tutela sem urgência em demandas repetitivas é o art. 285-A do CPC, ou

\footnotetext{
${ }^{212} \mathrm{~A}$ aproximação entre máximas de experiência e estatística (não a estatística formal, mas aquela vivenciada, donde se haver falado em sentimento estatístico), mereceu registro de FABRíCIO, Adroaldo Furtado. Fatos notórios e máximas da experiência, cit., p.438, e ROSITO, Francisco. Direito probatório: as máximas de experiência em juízo, cit., p. 79.
} 
melhor, a idéia que ele inseriu no sistema do processo, segundo a qual o convencimento do juiz, mesmo prematuro, o impõe decidir. Ilustrou-se, aliás, as conseqüências sistêmicas da inserção daquele artigo com a indagação de Luiz Guilherme Marinoni e Sérgio Cruz Arenhart (n. 10, supra). Em suma, se o sistema reconhece que o improcedente de plano merece pronta decisão, como ficam, perguntaram eles, as situações inversas, em que se verifica a procedência prima facie? De lá para cá, o estudo girou em torno do convencimento suficiente para decidir e, por conseqüência, em torno do tema da prova. Foi assim que se chegou ao exame das máximas da experiências e aos fatos notórios. No âmbito da incidência direta do art. 285-A, o julgamento imediato é viável, porque não há espaço para dúvidas sobre fatos. Mesmo que a narrativa fática seja inverídica, como se pôde demonstrar recorrendo ao exemplo do corte de energia elétrica, ainda assim não há espaço para dúvidas. Então, para inserir a antecipação de tutela na zona de influência daquele dispositivo legal, no sentido de incorporar o valor que ele insere no sistema, era preciso comprovar que também aqui há um nível de convicção similar em termos de intensidade. E, uma vez demonstrado, promover a adaptação. Ou seja, se não é possível falar em sentença de procedência prima facie (nem tanto por problemas relacionados com o convencimento, mais em homenagem ao contraditório), por simetria é viável um equivalente da decisão, que é o adiantamento dos efeitos práticos, total ou parcialmente.

Antes de encerrar, é necessário deixar dois registros. Primeiro, de que o estudo das máximas de experiência geralmente envolve tratar da chamada prova prima facie, instituto originado no direito alemão, especificamente no âmbito das demandas indenizatórias por culpa extracontratual, em que o autor experimenta grande dificuldade de prova direta da responsabilidade, por um lado, mas, por outro, o fato sinaliza por si mesmo o responsável, mediante presunção formulada no contexto da ordinariedade ${ }^{213}$. Entre nós, quem tratou mais detalhadamente do tema foi Moacyr Amaral Santos, ilustrando-o com um exemplo paradigmático: se alguém é atingido por um tijolo que se desprende de um edifício em construção, tudo estará a indicar a responsabilidade do construtor ${ }^{214}$.

A estrutura do raciocínio na construção do convencimento é no mesmo sentido das hipóteses estudadas neste capítulo, na parte em que se trata das máximas da experiência. Entretanto a doutrina inclina-se por visualizar na prova prima facie regra de alteração do

\footnotetext{
${ }^{213}$ Nesse sentido, MELERO, Valentin Silva. La prueba procesal. Madrid: Editorial Revista de Derecho Privado, 1963. t. 1, p. 58-60.

${ }^{214}$ SANTOS, Moacyr Amaral. Prova judiciária no cível e comercial. 2. ed. atual. São Paulo: Max Limonad, 1955. v. 5, p. 430.
} 
ônus da prova, a ser manejada apenas na ocasião da sentença final ${ }^{215}$, na mesma linha de operação destinada pelo legislador ao inciso VIII do art. $6^{\circ}$ do Código do Consumidor. Por isso, e porque o universo deste estudo é fundamentalmente o das repetições - que não constituem a base da prova prima facie -, dispensou-se exame mais detalhado do instituto.

A segunda observação relaciona-se ao princípio do contraditório. A formulação dos institutos das máximas da experiência e do fato notório coordena-se com a idéia de que eles surgem apenas na ocasião da sentença, surpreendendo as partes. Isso porque, no contexto da ordinariedade, só há decisão baseada no mérito do litígio no momento final, que é o da sentença. Nesse sentido, Adroaldo Furtado Fabrício: “A fonte do convencimento judicial, em tais situações, acha-se fora dos autos e neles não chega a penetrar senão quando da fundamentação do julgado, por iniciativa do juiz e independentemente de prévia submissão ao exame das partes”. Assim posicionados na cronologia do processo, o risco ao contraditório é, portanto, uma fronteira rigorosa, rigor que acaba inibindo a utilização daqueles instrumentos.

O problema fica mitigado, no entanto, em se tratando de antecipação de tutela, pois em todos os casos em que ela sobrevier antes da sentença, sempre haverá contraditório posterior sobre o fato notório ou a máxima de experiência eventualmente utilizados pelo juiz.

Feitos os registros, e considerando tudo o que foi visto até agora, é possível concluir que o tema das provas e do convencimento suficiente não representa óbice à inserção da hipótese no universo de influência do art. 285-A, naquilo em que ele significa um sinalizador do sistema, segundo o qual o juiz, estando convencido suficientemente, deve decidir, pelo menos outorgando os efeitos práticos ao direito que, em vista de repetições, se mostra evidente antes do fim do processo. Mas isso não é tudo, falta ainda justificar a localização exata da proposta na fórmula do $\S 6^{\circ}$ do art. 273 do CPC.

\footnotetext{
${ }^{215}$ Nesse sentido, ROSEMBERG, Leo. La carga de la prueba. Buenos Aires: Ediciones Jurídicas EuropaAmerica, 1956. p. 166-167.
} 


\section{A inserção da proposta na legislação processual}

\subsection{Introdução}

Desde o início do estudo, ficou destacado o corte metodológico que proporciona visualizar no interior do Judiciário dois tipos de litigiosidade a que correspondem, respectivamente, a "jurisdição convencional" e a "jurisdição de massificada". Também foi decisivo demonstrar, o que se fez até com uma certa insistência, que a segunda espécie assume um caráter híbrido, pois, embora se refira fundamentalmente à litigiosidade coletiva, em regra é veiculada por intermédio de ações individuais.

O posicionamento do debate nesse contexto revela características e oportunidades muito diversas daquelas que o intérprete dispõe quando encara o processo civil pelo ponto de vista exclusivo das demandas individuais. Primeiro, porque a massificação dos litígios já nasce como um problema público, haja vista a sua disseminação social. Em segundo lugar pelo impacto que tem produzido no interior do Judiciário, se não a ponto de paralisálo, pelo menos tornando-o excessivamente lento e, não raro, demasiado incoerente aos olhares de fora, o que por si só constitui questão a ser tratada em perspectiva política e social. Em terceiro, porque a racionalidade da jurisdição coletiva tem contornos que remetem o intérprete a um universo onde alguns temas de processo simplesmente se transformam, às vezes recusando o formato tradicional de maneira inconciliável (a coisa julgada, por exemplo ${ }^{216}$ ), outras vezes aceitando um manejo em níveis de quase obviedade, como ocorre no âmbito do convencimento em vista das repetições, tema amplamente examinado, e em conexão com ele o próprio contraditório e a ampla defesa.

Eis, portanto, o cenário da proposta deste estudo, no interior do qual ela desempenha mais de um papel.

Na perspectiva política e social, por exemplo, a generalização das antecipatórias de tutela em ações repetitivas, dependendo apenas da evidência do direito e sem mais condicionamentos, opera no sentido de afastar zonas de absurdo, que a sociedade enxerga

\footnotetext{
${ }^{216}$ Rodolfo de Camargo Mancuso nas considerações conclusivas de sua obra sobre jurisdição coletiva e coisa julgada, sintetiza as razões estruturais por que o instituto da coisa julgada formulado no processo convencional perde aderência no ambiente das ações coletivas, onde acabou tratado secundum eventum litis. MANCUSO, Rodolfo de Camargo. Jurisdição coletiva e coisa julgada: teoria geral das ações coletivas, cit., p. 550-557.
} 
de fora sem condições de compreender, como aquela em que o correntista que não tenha como alegar periculum in mora obriga-se a aguardar dois anos ou mais para receber suas diferenças do Plano Bresser (n. 5 e n. 8.1, supra). Situações do tipo desta, a um só tempo significam litigiosidades não resolvidas e deslegitimação do Poder Judiciário, que aos olhos da sociedade não consegue ultrapassar o óbvio e, assim, perde prestígio e se desafirma.

No âmbito da organização econômica, a pronta realização dos efeitos práticos do direito repetitivo inibe o inadimplemento em massa porque suprime os ganhos que a demora oferece a determinados agentes, o que tende a diminuir a própria litigiosidade. Assim quanto aos repeat players (litigantes frequientes), por exemplo, identificados na pesquisa de Boaventura Souza Santos mencionada na parte inicial do estudo (n. 1.1). A pronta realização do direito evidente faz desaparecer as vantagens de eles estarem em juízo, além de significar fator de moralização do ambiente judiciário.

Ademais, no jogo social, os movimentos dos agentes econômicos (notadamente as grandes empresas) são concebidos em parte pelo cálculo dos movimentos dos demais agentes, dentre os quais o Judiciário. A vida de uma empresa capitalista é um eterno procurar de oportunidades, e a linguagem dela é o lucro. Portanto as oportunidades de lucro constituem o foco do agente capitalista, e nessa linha ele sempre examinará a natureza do agir do Judiciário como variável para pautar sua própria conduta em busca de posições lucrativas. Por isso a eficiência do Judiciário em recepcionar e processar com racionalidade as demandas de massa (entre as quais incluímos a antecipação da tutela sem o requisito da urgência) é também um fator de manejo de litigiosidade futura, na medida em que se converte em informação ao agente econômico.

Do ponto de vista individual, a desburocratização que a antecipatória de tutela aqui tratada viabiliza produz efetividade, porque realiza na prática o direito evidenciado de plano.

Naturalmente, a litigiosidade de massa é um enorme corpo, cujas raízes insuperáveis crescem sem nenhum sinal de retrocesso, alimentadas no ambiente externo do Judiciário. Uma simples fórmula processual pode muito pouco em um contexto tão grandioso. Mas alguns pequenos ajustes, às vezes, significam avanços consideráveis. A partir da vigência do Código Civil de 2002, por exemplo, o fato de que os juros de mora praticados em juízo sofreram ligeira alteração, passando de $0,5 \%$ ao mês para $1 \%$, produziu significativa redução de demandas condenatórias e execuções contra indivíduos 
solventes. E a explicação é matemática: nenhum investimento financeiro convencional rende mais que a correção e o juro praticados em juízo. Ou seja, dever em juízo, para grande parte das pessoas, passou a ser desvantajoso com o ligeiro incremento da taxa de juros judiciais. Outro detalhe operacional, a chamada penhora on line, vem igualmente produzindo redução significativa de litigiosidade (entre devedores solventes, vale repetir), assim como a multa instituída na primeira fase do cumprimento de sentença condenatória pecuniária (art. 475-J, do CPC). De modo que, colocada em seu devido lugar, ainda assim a antecipação de tutela sem urgência para demandas repetitivas justifica-se amplamente, o dá sentido à tarefa de enquadrá-la no sistema.

\subsection{Justificativas constitucionais}

Mesmo um exame sem maior profundidade do contexto constitucional justifica a proposta de antecipação de tutela de que se vem tratando. A garantia decorrente do princípio da tempestividade (aspecto da efetividade da jurisdição), em geral se encontra tensionada pela pressão contrária da segurança jurídica, princípio de igual hierarquia. Convivem assim em uma espécie de permanente antinomia, que se resolve pela hierarquização de um ou de outro desses dois valores, quando verificada situação concreta a exigir um posicionamento do intérprete. Todo o aporte teórico que o raciocínio pressupõe foi detalhado no ns. 4.4 a 4.6, acima, dispensando a reconstrução das premissas teóricas lá posicionadas.

Prosseguindo, a evidência do direito repetitivo, nos termos sustentados neste estudo, faz desaparecer a tensão entre os princípios, porque os fins da segurança jurídica foram alcançados suficientemente, não raro prima facie. Com isso, deixa de haver justificativa para que a providência de efetivação do direito permaneça contida à espera do término do procedimento. E sem a justificativa da segurança jurídica, a "demora desnecessária" que se instala a partir de então é inconstitucional.

Para uma visão mais ampliada, tomemos o ponto de vista do devido processo substancial. A compreensão instrumental desse princípio, em que ele é concebido basicamente como conjunto de regras acerca da ampla defesa e do contraditório ${ }^{217}$, estabelecidas previamente à situação litigiosa, evoluiu para incorporar a proteção dos

\footnotetext{
${ }^{217}$ OLIVEIRA, Carlos Alberto Alvaro de. Do formalismo no processo civil, cit., p. 86.
} 
direitos fundamentais na dinâmica do processo - ou seja, de justiça processual -, sendo um critério possível para balizar a prática dessa linha de proteção a razoabilidade ${ }^{218}$. Ou seja, situações incompatíveis com a razoabilidade indicam o eventual desrespeito ao devido processo na sua acepção substancial. Foi assim que a Constituição brasileira incorporou o princípio, como explicado no n. 4.4, supra. Desse quadro retira-se que a "injustiça procedimental", presente quando a evidência do direito se instala mas não é seguida de nenhum efeito prático, é um mal a ser debelado, porque contrasta com devido processo. Vale dizer: não se pode admitir que a realização formal do rito produza resultados nãorazoáveis, que se distanciem de um postulado elementar de racionalidade, como acontece, com maior ou menor intensidade, nos exemplos formulados ao longo do trabalho.

Com efeito, percebe-se claramente o desvio de irracionalidade naquele conjunto de exemplos, pelo que se pode afirmar a inconstitucionalidade em tela de exame, também pela via do devido processo.

Mas o rito está na legislação processual, que não pode ser acusada de inconstitucionalidade em tese, até porque funcionalizada para veicular aquelas situações em que a tensão entre os dois princípios (segurança jurídica/tempestividade) apresenta-se ordinariamente. Visto assim, há duas soluções possíveis: ou permite-se ao aplicador do direito, em cada caso concreto, pronunciar a inconstitucionalidade e criar ele próprio um procedimento que não existe na lei, para assim realizar a vontade constitucional em concreto $^{219}$, ou se deve procurar o acomodamento da anomalia mediante adaptação das

\footnotetext{
${ }^{218}$ De “razoabilidade ou de racionalidade", no dizer de Carlos Alberto Alvaro de Oliveira, Do formalismo no processo civil, cit., p. 87 ;

${ }^{219}$ Carlos Alberto Alvaro de Oliveira é categórico quanto a que o juiz não pode criar regras procedimentais: "E se mostra evidente, em face até do princípio da legalidade, a inadmissibilidade de que os magistrados pudessem criar ou alterar regras procedimentais, mesmo quando imperfeitas ou insatisfatórias as existentes. Do formalismo no processo civil, cit., p. 186. Sérgio Gilberto Porto posiciona-se favoravelmente à criação de direito processual in concreto, embora prefira a adaptação de fórmulas já existentes, se possível: "Desta forma, em face da ausência de regra processual ou inadequação desta à natureza do direito posto em causa e à qualidade da parte, está o juízo autorizado a buscar eficiência para o processo, aos efeitos de tornar a jurisdição útil e efetiva, pela via da disciplina especial do caso, criando, verdadeiramente, direito processual in concreto, tudo desde que respeitando sempre o devido processo legal substancial, representado pela prevalência das garantias constitucionais-processuais-expressas ou implícitas- consagradas na Carta Magna. Dito de outro modo, na ausência de disciplina processual própria ou inadequação desta, diante da natureza do direito posto em causa ou a qualidade da parte, está o juizo, em face da função criativa (inerente ao seu ofício!), autorizado a estabelecer disciplina processual concreta, desde que respeitadas as garantias constitucionais-processuais integrantes da ordem jurídica constitucional”. PORTO, Sérgio Gilberto. A crise de eficiência do processo: a necessária adequação processual à natureza do direito posto em causa, como pressuposto de efetividade. In: FUX, Luiz; NERY JÚNIOR, Nelson; WAMBIER, Teresa Arruda Alvim (Coords.). Processo e Constituição: estudos em homenagem ao Professor José Carlos Barbosa Moreira, cit., p. 189.
} 
próprias normas processuais. E, com efeito, havendo essa última possibilidade - como há neste caso - ela é sempre preferível àquela.

Postas assim as premissas, e considerando que a antecipação da tutela em caráter genérico no CPC brasileiro justifica-se em três hipóteses (urgência, incontrovérsia e protelação ou abuso de direito de defesa), será preciso demonstrar o sentido da opção pela antecipatória baseada em direito incontroverso, como se passa a fazer a partir de agora.

\subsection{O posicionamento da proposta no art. $273, \S 6^{\circ}$, do do CPC}

A lógica do raciocínio desenvolvido até agora sobre a jurisdição de massa, a repetitividade e o modelo de convencimento no ambiente das repetições, estabelece um paralelo muito estreito com o art. 285-A do CPC, que prevê a sentença de improcedência prima facie, sugerindo que o desenrolar deste trabalho pudesse levar a um tipo de sentença liminar, em simetria com a do citado artigo de lei, estabelecendo a procedência prima facie do direito evidente. Enfim, algo comparável àquela modalidade de référé mencionada no n. 2.2.5, supra, em que o juiz francês resolve de imediato o conflito, cabendo às partes decidir, depois, se lhes interessa repropô-lo na via ordinária, ou não. Aliás, talvez isso venha a ser previsto no direito brasileiro se aprovado o projeto de estabilização da tutela antecipatória, cujo objetivo é "em síntese, tornar definitivo e suficiente o comando estabelecido por ocasião da decisão antecipatória”, ficando a critério das partes decidir "sobre a conveniência, ou não, da instauração ou do prosseguimento da demanda e sua definição em termos tradicionais ${ }^{, 220}$.

Mas hoje isso implicaria a criação de fórmula que não existe no sistema, tarefa provavelmente inviável. Daí o recurso ao artigo $273, \S 6^{\circ}$, do CPC.

Antes de prosseguir observe-se, contudo, para que não se perca o fio condutor, que o mencionado dispositivo é ponto de chegada e não ponto de partida deste estudo. Quer dizer: a direção do raciocínio conduzirá a interpretação conforme um sistema de idéias e

\footnotetext{
${ }^{220}$ Conforme GRINOVER, Ada Pellegrini. A antecipação de tutela e sua estabilização. In: MARINONI, Luiz Guilherme (Org.). Estudos de direito processual civil: homenagem ao Prof. Egas Dirceu Moniz de Aragão. São Paulo: Ed. Revista dos Tribunais, 2005. p. 231.
} 
necessidades pressuposto, o que é determinante para superar problemas exegéticos mais adiante identificados ${ }^{221}$.

Prosseguindo, a edição de uma nova norma constitucional, especialmente se marcada pelo traço programático, impõe a releitura do direito infraconstitucional à procura de espaços de realização dos objetivos traçados por ela. Cumprindo essa diretriz, com o fim de realizar o princípio da tempestividade da jurisdição inserto no inciso LXXVIII do art. $5^{\circ}$ da CF no contexto das demandas repetitivas, é momento de reler o art. 273 do CPC. Sua redação, no que interessa, é a seguinte:

“Art. 273. O juiz poderá, a requerimento da parte, antecipar, total ou parcialmente, os efeitos da tutela pretendida no pedido inicial, desde que, existindo prova inequívoca, se convença da verissimilhança da alegação e:

"I - haja fundado receio de dano irreparável ou de difícil reparação; ou

"II - fique caracterizado o abuso do direito de defesa ou o manifesto propósito protelatório do réu.

" $\$ 6^{\circ}$. A tutela antecipada também poderá ser concedida quando um ou mais dos pedidos cumulados, ou parcela deles, mostrar-se incontroverso.

A interpretação consagrada tem sua primeira zona de interesse na especial convicção que a prova trazida pelo autor deve provocar no juiz. Não se trata de certeza, naturalmente, mas forte impresão acerca da probabilidade de existência do direito alegado. Esse requisito, que se localiza no caput e é comum para as três modalidades de antecipação, em nada se opõe à proposta aqui desenvolvida, pois o direito evidente alcança e ultrapassa a exigência legal.

O inc. I correponde às situações em que a antecipatória se justifica na urgência, pois a demora do processo, ainda que tão-só a "demora necessária", pode provocar o perecimento do direito ou a sua perda de sentido para o provável titular. É com o fim de evitar essa ordem de prejuízos que se antecipam efeitos práticos na forma do mencionado inc. I. Trata-se de hipótese que está fora das fronteiras deste estudo, pois aqui o foco é a só

\footnotetext{
${ }^{221} \mathrm{Na}$ hermenêutica constitucional contemporânea a idéia central é a de que o intérprete geralmente trabalha com mais de uma possibilidade exegética, devendo orientar-se na escolha, entre outros fatores, pela realidade do caso concreto, na busca da "melhor resposta" (WEINGARTNER NETO, Jayme. Existe a única resposta jurídica correta? Direito e Democracia, Porto Alegre, v. 5, n. 1, p. 115, 2004). Aqui, ao procurar o sentido do $\S 6^{\circ}$ estamos realizando interpretação constitucional, na medida em que o inserimos no âmbito da influência do inc. LXXVIII do art. $5^{\circ}$ da CF. Por outro lado, o caso concreto, é o fenômeno das ações repetitivas e da evidência do direito que as repetições produzem. Por isso se afirma que há um conjunto de necessidades e idéias pressuposto.
} 
evidência do direito, motivada por repetições, como fator determinante da antecipação da tutela.

O inciso II tem em vista o procedimento desleal do demandado, que se configura no abuso do direito de defesa ou no manifesto propósito protelatório. O caráter é sancionatório $^{222}$ ou punitivo ${ }^{223}$, o que estabelece, em princípio, vinculação com o instituto da litigância de má-fée ${ }^{224}$. Nesses limites, não tem conexão com o objeto da proposta deste trabalho.

Chega-se, assim, à terceira categoria, que é a do direito incontroverso do $\S 6^{\circ}$. Há consenso sobre esse tipo de antecipação dispensar o periculum in mora e, pois, não tem a ver com a tutela de urgência. Sua razão de ser estaria vinculada ao instituto do julgamento antecipado. Em suma, quando o autor cumula dois pedidos ${ }^{225}$, por exemplo, pode ter contestado apenas um deles. Em tal hipótese, se tivesse proposto os pedidos em relações processuais apartadas, aquele sobre o qual não houve contestação teria sido julgado ao final da fase postulatória (julgamento antecipado da lide), o que não é possível se estiver cumulado com outro que exija dilação probatória. Há, aí, prejuízo decorrente da cumulação, que consiste no retardamento da solução da lide incontroversa, que terá de aguardar até final sentença. Sendo esse o vetor na construção da norma, o legislador foi um pouco adiante para abranger não só pedidos cumulados incontroversos, mas também parte de pedido não contestado.

Exemplo é cobrança judicial de $\mathrm{R} \$ 100.000,00$, em que o réu contesta dizendo dever apenas $\mathrm{R}$ \$ 50.000,00 sem qualquer outra oposição. Cabe, aí, a antecipação de $\mathrm{R}$ \$ $50.000,00$, considerando a confissão a indicar o incontroverso ${ }^{226}$, na forma do mencionado $\S 6^{\circ}$ do art. 273 do CPC.

Mesmo que a exegese do dispositivo ficasse limitada à idéia de não-contestação e similaridade com o julgamento antecipado, ainda assim, ter-se-ia novidade no sistema, pois a sentença (do suposto julgamento antecipado) não seria executável de imediato, como regra, enquanto a tutela antecipatória, porque inserida no art. 273 , pode ser efetivada

\footnotetext{
${ }^{222}$ Conforme LOPES, Bruno Vasconcelos Carrilho. Tutela antecipada sancionatória, cit.

${ }^{223}$ Conforme ZAVASKI, Teori Albino. Antecipação de tutela. 5. ed. São Paulo: Saraiva, 2007. p. 78.

${ }^{224}$ Nesse sentido, BEDAQUE, José Roberto dos Santos. Tutela cautelar e tutela antecipatória: tutelas sumárias e de urgência (tentativa de sistematização). 3. ed. São Paulo: Malheiros Ed., 2001. p. 326.

${ }^{225} \mathrm{O}$ raciocínio não se presta a todo o tipo de cumulação, mas tão-só para os casos de cumulação simples ou sucessiva de pedidos, conforme José Rogério Cruz e Tucci, Lineamentos da nova reforma do CPC. 2. ed. São Paulo: Ed. Revista dos Tribunais, 2002. p. 43.

${ }^{226} \mathrm{O}$ exemplo é enunciado nesses termos por MARINONI, Luiz Guilherme. Antecipação da tutela. 9. ed. São Paulo: Ed. Revista dos Tribunais, 2006. 357.
} 
prontamente. Isso, no entanto, produz incoerência sistêmica, pois quem tem o mais (a sentença) pode o menos, uma vez que sujeito ao exaurimento prévio das demoradas fases recursais para realizar os efeitos práticos da decisão ${ }^{227}$.

Outro problema é saber se o regime da execução (efetivação) da medida, não estando ela baseada na urgência, haveria de ser realizado no mesmo ritmo e seguindo os mesmos princípios da realização prática de autêntica sentença, com execução provisória, inclusive.

Para solver os impasses surgiram, basicamente, dois posicionamentos. O primeiro preconiza uma espécie de cisão ${ }^{228}$ do processo, aferindo os elementos essenciais de autêntico ato sentencial na decisão antecipatória e tratando-a como tal para todos os efeitos $^{229}$. É uma linha de pensamento totalmente informada pela idéia do julgamento antecipado, que teve impulso com a alteração do conceito de sentença, em vista da nova redação do art. 162 do CPC, dada pela Lei 11.232, de dezembro de 2005. Sendo assim, a solução preconizada é algo como desfazer a cumulação e, em se tratando de pedido parcialmente incontroverso, fracionar a lide. Exige, por certo, o encerramento da fase postulatória, inviabilizando a decisão liminar com base no incontroverso e, por coerência, também tornando inviável a produção dos efeitos práticos antes do trânsito em julgado ${ }^{230}$.

\footnotetext{
${ }^{227}$ José Roberto dos Santos Bedaque, constatando a incoerência, propõe regra segundo a qual a toda a sentença de julgamento antecipado, baseada em falta de controvérsia, o juiz deve conferir antecipação da tutela concomitante, de modo a equiparar com o tratamento do direito incontroverso no $\S 6^{\circ}$ do art. 273 do CPC. Tutela cautelar e tutela antecipatória: tutelas sumárias e de urgência (tentativa de sistematização). p. 332-333. No mesmo sentido Luiz Guilherme Marinoni, com remissão ao direito italiano, especificamente o art. 186-quarter do CPC daquele País. MARINONI, Luiz Guilherme. Tutela antecipatória e julgamento antecipado: parte incontroversa da demanda, cit., p. 119-120.

${ }^{228}$ Segundo José Joaquim Calmon de Passos, a decisão "transita em julgado (...). Daí sustentar que, na hipótese do $\S 6^{\circ}$, já que admitida a cindibilidade, não se antecipa, sim defere-se em caráter definitivo" PASSOS, José Joaquim Calmon de. Comentários ao Código de Processo Civil. 9. ed. Rio de Janeiro: Forense, 2005. v. 3, p. 72.

${ }^{229}$ Nesse sentido, DIDIER JUNIOR, Fredie. Inovações na antecipação dos efeitos da tutela e a resolução parcial de mérito. Revista de Direito Processual Civil, n. 26, p. 717, 2002: "a decisão que aplicar o $\$ 6^{\circ}$ do art. 273 é uma decisão interlocutória, que versa sobre parte do mérito, definitiva, fundada em cognição exauriente (juízo de certeza não de verossimilhança) apta a ficar imune pela coisa julgada material e passível de execução também definitiva.". Na mesma linha, entendendo definitiva e imodificável a decisão, mas não pela coisa julgada, e sim pela preclusão, Sérgio Cruz Arenhart: A antecipação de tutela e as alterações da lei 10.110/2002. In: MARINONI, Luiz Guilherme (Coord.). Estudos de direito processual civil: homenagem ao professor Egas Moniz de Aragão. São Paulo: Ed. Revista dos Tribunais, 2005. p. 284285.

${ }^{230}$ Há precedente na jurisprudência do Tribunal de Rio Grande do Sul, com amplo levantamento doutrinário sobre o tema, em que a decisão foi titulada como sentença parcial, estabelecendo própria que o recurso seria o de apelação por instrumento: processo 10522676506. TRIBUNAL DE JUSTIÇA DO ESTADO DO RIO GRANDE DO SUL. Disponível em: <www.tj.rs.gov.br>. Acesso em: 26 jan. 2009. A sentença foi cassada pela $5^{\text {a }}$ Câmara Cível do TJRS.
} 
Outra solução pauta-se pela observância parcial dos princípios do julgamento antecipado, tal como o direito brasileiro o concebe. Assim, posiciona a decisão após a fase da resposta do réu, mas sustenta a sua natureza interlocutória, abrindo a possibilidade da imediata execução, em geral provisória. Não cogita, igualmente, de decisão inaudita altera parte $^{231}$.

As interpretações não ficaram restritas aos temas acima referidos. Também padeceu de instabilidade desde cedo o conceito de incontroverso. A acepção tradicional, em que significa falta de contestação, vem sendo forçada para alargar a hipótese de incidência da norma, mediante sugestões exegéticas não necessariamente vinculadas à mens legislatoris e, pois, sem emprestar relevância total ao tema como julgamento antecipado. Assim, por exemplo, José Rogério Cruz e Tucci ao observar que: “(...) pelo disposto no novo $\S 6^{o}$, havendo cumulação simples ou sucessiva de pedidos, a antecipação pode ser deferida nos limites da matéria incontroversa, resultante, por certo, da prova inequívoca produzida já com a petição inicial, ou, ainda, admitida pelo réu após a contestação"232.

Embora a manifestação se reduza apenas ao transcrito acima, sem outro desenvolvimento, tudo indica que ao referir o incontroverso como resultado da prova produzida com a inicial, o jurista estava a pensar no incontroverso prima facie, independentemente da manifestação do réu. E, se foi essa a intenção, é uma incontrovérsia que se contrapõe ao entendimento tradicional.

Alguns doutrinadores sustentam que a locução significa mais que o não-discutido, incluindo o indiscutível ${ }^{233}$, no que Teori Albino Zavaski vislumbra importante conseqüência, afirmando viável a aplicação do dispositivo até mesmo às demandas que versam sobre direito indisponível ${ }^{234}$. Isso, na concepção tradicional de incontroverso é impossível, porque só se verifica o fenômeno quando o réu tem escolha, inclusive de sacrificar seu eventual direito, silenciando sobre a pretensão do autor.

O mesmo jurista amplia ainda mais o conceito para nele incluir o não seriamente contestável, fórmula similar a do référé em que se antecipam efeitos práticos de direito evidente, assim considerado quando "non seriamente contestabile”, como dá notícia Dino

\footnotetext{
${ }^{231}$ Por todos, ZAVASKI, Teori Albino. Antecipação de tutela, cit., p. 113-114.

${ }^{232}$ CRUZ E TUCCI, José Rogério. Lineamentos da nova reforma do CPC, cit., p. 43.

${ }^{233}$ Nesse sentido, NERY JUNIOR, Nelson; NERY, Rosa Maria de Andrade. Código de Processo Civil comentado e Legislação Extravagante. 10. ed. São Paulo: Ed. Revista dos Tribunais, 2008. p. 530, e Teori Albino Zavaski: “incontroverso, em suma, não é o 'indiscutido', mas o 'indiscutível'”. Antecipação de tutela, cit., p. 110.

${ }^{234}$ ZAVASKI, Teori Albino. Antecipação de tutela, cit., p. 109.
} 
Buoncristiani $^{235}$. Ao fazê-lo, Teori Albino Zavaski exemplifica com litígios de massa em que haja posição pacificada, majoritária ou não, sumulada, etc, dos tribunais superiores. Trata-se de uma sensível aproximação ao tipo de alargamento exegético que se procura neste ponto do estudo ${ }^{236}$, embora o jurista restrinja em outros setores, pois só admite a decisão após a fase de resposta do réu ${ }^{237}$, equiparando-a, assim, ao julgamento antecipado. A ponto de admitir que melhor seria que o legislador tivesse previsto a "cisão do julgamento, permitindo sentença parcial, mas definitiva de mérito" ${ }^{238}$. Nessa linha, os atos de efetivação seguem o ritmo convencional, no seu entendimento, pois "não há por que adotar regime diferente do que seria adotado em caso de execução provisória da correspondente sentença de procedência” 239.

Transportado para cá o exemplo do paciente interno em hospital, que não tem periculum in mora porque é abastado, cujo plano de saúde suspende a cobertura dos custos de hospitalização mediante ato repetidamente julgado irregular em demandas precedentes, e sumulado, inclusive, pelo STJ, haveria evidência, no entender do jurista, mas a realização prática dependeria da propositura da ação, citação do réu, decisão interlocutória e execução provisória, que só muito demorada e dificilmente se transforma em realidade prática antes

\footnotetext{
235 “Unico requisito di ammissibilità del référé provision (...) è l'esistenza di un'obbligazione non seriamente contestabile. Per poter apprezzare ciò, il giudice deve esaminare il mérito della controvérsia e raggiungere la "soglia dell' evidenza" (seuil d'evidence), cioè stabilire fino a che punto è dubitabile l'esistenza del diritto di credito". E prossegue o autor, registrando que não se exige o requisto da urgência além da evidência do direito incontestável. BUONCRISTIANI, Dino. Sistema dei "référé": tutela cautelare dal pregiudizo e tutela urgente senza pre-giudizio, cit., p. 588. Também é exemplo, no direito italiano, a determinação de pagamento de quantia não contestada presente no art. 186 bis c.p.c., conforne FAZZALARI, Elio. Instituições de direito processual. Campinas: Bookseller, 2006. p. 183-184

${ }^{236} \mathrm{~A}$ passagem em que ele remete às demandas repetitivas é a seguinte: “(...) é apropriado concluir, quando se interpreta o $\$ 6^{\circ}$, que a controvérsia apta a inibir a antecipação da tutela há de se revestir de um mínimo de seriedade e razoabilidade. Nesse enfoque, pode-se dar ao conceito de pedido incontroverso um sentido ampliado, mais afinado com a interpenetração teleológica da norma: será considerado incontroverso o pedido, mesmo contestado, quando os fundamentos da contestação sejam evidentemente descabidos ou improcedentes. Em outras palavras: quando não haja contestação séria./ Essa ausência de seriedade ou razoabilidade, todavia, há de ser medida, não apenas a partir da convicção pessoal do juiz, mas à luz de critérios objetivos fornecidos pelo próprio sistema do processo. Por exemplo: não se poderá ter como controvertido um pedido que esteja fundado exclusivamente na negação de um fato notório (CPC, art. 334, I); também não se pode ter como controvertido um pedido cuja contestação tenha por fundamento exclusivo alegação (a) contrária a decisões de caráter vinculante, como são as produzidas no âmbito do controle concentrado de constitucionalidade (Lei n. 9.868, de 10-11-1999, art. 28, parágrafo único), ou (b) contrária à súmula ou jurisprudência firme do Supremo Tribunal Federal ou do Superior Tribunal de Justiça, hoje tão prestigiados em nosso sistema (CPC, arts. 475, $\S 3^{\circ}, 518, \S 1^{\circ}$, e 558)" ZAVASKI, Teori Albino. Antecipação de tutela, cit., p. 111.

${ }^{237}$ A exigência da contestação prévia na obra do jurista pode ser constatada na seguinte passagem: “outorga poderá ocorrer a qualquer tempo, no curso do processo, a partir do momento em que ficarem configurados os requisitos, mormente o da incontrovérsia, somente verificável a partir da contestação" ZAVASKI, Teori Albino. Antecipação de tutela, cit., p. 113.

${ }^{238}$ ZAVASKI, Teori Albino. Antecipação de tutela, cit., p. 112.

${ }^{239}$ ZAVASKI, Teori Albino. Antecipação de tutela, cit., p. 113-114.
} 
do trânsito em julgado da sentença. O mesmo se diga do consumidor que procura obter suas diferenças do Plano Bresser.

Os objetivos sociais, políticos e jurídicos que foram longamente justificados não se realizam. E se pensarmos na realidade operacional da justiça, talvez nem o "atalho" que a execução provisória pretende produzir aconteça na prática, tal a forma como os processos de massa são conduzidos. Em suma, o que pode ocorrer é que o sistema se ressinta tão-só de mais trabalho, somando-se ao já abarrotado serviço judiciário, sem contrapartida de efetividade.

A exegese que tem no $\S 6^{\circ}$ o ponto de partida pode ser levada a esse tipo de resultado, aparentando internamente um real avanço, sem apresentar, na realidade prática, efetiva operacionalidade. Por isso entendemos que o caminho deveria ser o inverso, partindo daquela realidade, examinando o congestionamento judiciário, a contaminação que a "jurisdição de massa" provoca na "jurisdição convencional”, as zonas de absurdo de que se falou, e as oportunidades que foram surgindo enquanto se avançava. E agora fica mais fácil orientar-se no manejo exegético do $\S 6^{\circ}$.

"Incontroverso" é atributo do que é certo. Bem por isso na etimologia da palavra, segundo Antonio Houaiss, um dos sentidos é “indiscutível”, outro é “indubitável”. Já a expressão "evidente" ou "evidência", também considerada etimologicamente, significa "o que não oferece dúvida”. Portanto, mesmo na exegese mais pobre - a literal - é viável dizer que o "evidente" é também incontroverso, porque indubitável. Ademais, o que a Lei tem em vista ao falar no caráter incontroverso do pedido é o estado de convicção que se forma na consciência do juiz autorizando-o a julgar. E tal estado também a evidência confere ao julgador, obviamente.

Do ponto de vista sistemático, a equiparação do incontroverso ao evidente não poderia caber antes do momento próprio da sentença, haja vista os postulados do contraditório e da ampla defesa, como requisitos indispensáveis à formação do convencimento suficiente como regra no processo. Mas se considerado o universo específico das demandas repetitivas e o conseqüente regime de convencimento diferenciado de que se tratou no corpo do estudo, a inviabilidade desaparece, e então as duas locuções podem ser equiparadas sem dificuldade.

Por fim, a escolha do intérprete entre duas possibilidades interpretativas deve sempre privilegiar aquela que realiza melhor os vetores constitucionais. E assim é, neste caso, a escolha que afirma a evidência no interior da locução incontroverso, desde que se 
pense em termos dos princípios da efetividade e da tempestividade ${ }^{240}$. Sem desconsiderar a segurança jurídica, naturalmente, que no contexto de evidência já foi alcançada, como se teve oportunidade de ilustrar acima.

Assim definida a exegese do $\S 6^{\circ}$ do art. 273 do CPC, fica certo, também, que nada obsta o deferimento inaudita altera parte do pedido antecipatório. Exceto a falta de convencimento liminar - mas aí não mais haverá evidência -, aferida nos termos do regime de convicção próprio das demandas repetitivas. E tudo converge para a imediata execução, a fim de produzir efeitos práticos, sem embargo do nome que se vá dar a essa execução (provisória ou definitiva). Os efeitos práticos mais ou menos imediatos são a essência da operacionalidade desse sistema, sem a qual ele acaba constituindo fonte de redobrado trabalho, perdendo-se na burocracia judiciária.

Postas assim as linhas gerais do sentido que se dá ao $\S 6^{\circ}$ do art. 273, vale particularizar o tratamento de algumas das afirmações feitas por último, para melhor esclarecer a viabilidade do resultado do estudo.

\subsubsection{Momentos próprios para a antecipação da tutela}

A questão do momento adequado para antecipar a tutela envolve-se com as razões pelas quais - e as condições como - se antecipa. Sendo um dos objetivos a contenção daquela litigiosidade que só desenvolve por causa da falta de respostas rápidas do Judiciário, em questões que poderiam ser, tomado o senso comum, rapidamente respondidas, o momento de antecipar é o do convencimento suficiente do juiz, que muitas vezes se forma na hora mesma que ele toma contato com a inicial da nova demanda. Nestes casos (e há exemplos que não necessitam ser reprisados) a justiça faz sentido para o demandado fundamentalmente por ser morosa ${ }^{241}$ - o estar em juízo não se dá prioritariamente por um problema jurídico -, e a antecipação da tutela proposta figuraria

\footnotetext{
${ }^{240}$ Bem antes da vigência da atual Constituição, José Carlos Barbosa Moreira assinava que a interpretação das normas de processo deve privilegiar as conclusões que confiram maior celeridade: "sem dúvida algum esforço deve e merece ser feito, para atenuar o mal em sede de interpretação das normas que regem o andamento das causas em juízo: sendo igualmente admissíveis dois entendimentos diversos, há de preferirse o mais favorável à rápida solução dos litígios". MOREIRA, José Carlos Barbosa. Notas sobre o problema da "efetividade" do processo. In: Temas de direito processual: $3^{\mathrm{a}}$ série. São Paulo: Saraiva, 1984. p. 209.

${ }^{241}$ Luiz Guilherme Marinoni faz a mesma conexão entre as antecipatórias e o combate ao congestionamento judiciário, sentido no qual essas decisões se explicam não só na solução do caso concreto. $\mathrm{O}$ argumento do jurista não se refere, como aqui, ao universo específico das demandas repetitivas, formulado que foi em termos gerais. MARINONI, Luiz Guilherme. Tutela antecipatória e julgamento antecipado: parte incontroversa da demanda, cit., p. 91-92.
} 
como uma resposta, com o fim de reposicionar as variáveis do cálculo econômico do litigante. Cândido Dinamarco situa no escopo social da jurisdição o caráter educativo, e é justamente esse o sentido que ora se destaca. Nem se trata de posicionar o Judiciário como quem admoesta o agente econômico. Afinal, o capitalismo e a sua lógica peculiar compõem a realidade social, e é dos elementos da sociedade em que opera que o Judiciário deve alimentar-se para, devolvendo-lhe o resultado da sua ação, orientar, reorientar e pacificar seus descompassos.

Essa forma de ver é própria do direito coletivo, e as demandas repetitivas são, em sua maioria, direito coletivo tratado em demandas individuais. Por isso, a efetividade, vista na perspectiva do titular individual, não está no primeiro plano, embora interaja com o todo e, nessa medida, tenha um sentido coletivo.

Sendo este o quadro, não há razão para, admitido que se deva antecipar tutela como proposto neste estudo, vetar o seu deferimento prima facie quando houver, nessa hora, condições de decidir. Estivesse o problema proposto tão-somente na perspectiva individual, a dificuldade seria outra para quem se dispusesse a sustentar a tutela antecipada liminar do direito evidente. Mas esta é uma tarefa dispensável neste trabalho, porque na perspectiva social e política o debate resta simplificado e de mais fácil justificação.

Para além disso, considerando que a baliza é o convencimento que se forma como produto de repetições, aproveitando-se de recursos como a notoriedade e as máximas da experiência, se o juiz não se sente convicto liminarmente, deverá rejeitar o pedido antecipado, ficando, no entanto, em condições de deferi-lo a qualquer tempo, inclusive na sentença, se for o caso.

\subsubsection{Contraditório e ampla defesa}

O tema objeto deste tópico é mais sensível em relação às antecipatórias deferidas sem a audiência prévia da parte demandada. Mas o próprio art. 273 do CPC prevê a solução, postergando o contraditório e o exercício da ampla defesa para depois do deferimento da medida. O problema se põe, então, em termos de justificativa para que a técnica seja acionada. Ou seja: saber se a evidência é bastante para autorizar a postergação do contraditório e da ampla defesa. 
Examinada a hipótese pelo ponto de vista de uma demanda individual, em que o autor não apresente necessidades emergenciais com relação ao objeto do litígio, a resposta poderá ser negativa, considerando a importância jurídica e cultural dos princípio supramencionados. Mas se especializarmos a análise, detendo-nos na anatomia da litigiosidade repetitiva, na obviedade que progressivamente vai-se impondo, consequiência das repetições, conforme exemplos apresentados ao longo do trabalho; se pensarmos, também, no estágio atual do CPC, que já inseriu valores diferenciados para o trato das demandas de massa, o cenário muda completamente. Aí, se não em todos os casos, certamente em muitos, a exigência do contraditório prévio será, na palavra autorizada de Cândido Dimanarco, provavelmente um excesso desnecessário:

\begin{abstract}
“(...) Os grandes princípios constitucionais do processo são em si mesmos perenes mas nem por isso devem ser cultuados como fetiches, nem sua leitura há de ser estanque no tempo. As garantias constitucionais do contraditório, do devido processo legal, da ampla defesa etc, são parâmetros a serem observados na construção e prática da lei processual, mas devem ser interpretados segundo as necessidades do tempo e os legítimos valores da sociedade a que servem. Acima de todos eles paira a garantia do acesso à justiça, também oferecida em sede constitucional (art. $5^{\circ}$, inc. XXXV) e complementada pela outra garantia consistente no direito à realização do processo em tempo razoável (...). Quando para a efetividade e necessária tempestividade da tutela jurisdicional for necessário infringir mediante simples arranhões alguns desses princípios, ou interpretá-los sem os radicalismos estagnários de uma leitura tradicionalista e conservadora, que isso seja feito porque assim caminha a História das instituições e assim convém à boa ordem jurídica e aos objetivos da justa pacificação pelas vias do processo. ${ }^{242}$.
\end{abstract}

De modo que não há óbice na seara reservada ao contraditório e à ampla defesa, que possa inviabilizar a antecipação da tutela ora pretendida, seja liminarmente, seja em fases posteriores, antes do fim do procedimento.

\title{
11.3.3. Efetivação da tutela antecipada
}

O problema relativo ao cumprimento das tutelas antecipatórias atrai a atenção no âmbito das obrigações pecuniárias, considerando que no regime de realização prática das obrigações de fazer e de entrega de coisa (arts. 461, $\S 3^{\circ}$ e 461-A, $\S 3^{\text {o, }}$ do CPC), a

\footnotetext{
${ }^{242}$ DINAMARCO, Cândido Rangel. Fundamentos do processo civil moderno, cit., v. 2, p. 905.
} 
morfologia do direito possibilita o cumprimento mais simplificado e sem distinções relevantes entre as decisões antecipadas e as definitivas.

Feita a ressalva, vamos admitir que haja regimes diferenciados de efetivação das antecipatórias pecuniárias no âmbito do art. 273 do CPC, definidos não só em função da urgência ou não-urgência, mas igualmente a partir de questionamentos sobre a natureza jurídica das decisões proferidas com base no seu $\S 6^{\circ}$ (sentença ou interlocutória), tema já examinado em tópicos anteriores. A melhor hipótese, em nosso entendimento (ainda que sem aprofundar o debate, porque dispensável, aqui, como será visto), é a que propugna pelo tratamento unificado, equiparando todas as antecipatórias para os fins da persecução dos resultados práticos e, assim, evitando a sobreposição de categorias que, na prática, tornam demasiado complexa a operação do instituto, que perde em simplicidade e dificulta o manejo dos operadores mais na linha de frente do dia-a-dia da justiça.

Ocorre que a proposta desenvolvida neste estudo só tem viabilidade se for possível retirar efeitos práticos em tempo razoável da decisão antecipatória; se a realização prática não ficar à mercê da dispersão da artilharia de impugnações formais que os litigantes freqüentes (repeat players) são visceralmente equipados para produzir e reproduzir. Em suma, a operacionalidade da proposta depende de um regime de efetivação equiparado ao das tutelas urgentes.

Diga-se que a assimilação faz sentido, por outro lado, no fato de que a evidência opera com um patamar de risco inferior ao da urgência, justificativa adicional à realização prática de um direito que só excepcionalmente não conferirá com o que prima facie apresenta-se ao juiz ${ }^{243}$.

Fixada a premissa, há pelo menos um ponto no tema da execução das antecipatórias urgentes que merece ser brevemente examinado. Vejamos.

O objetivo da Lei com o instituto da antecipação da tutela foi generalizar no processo civil a pronta realização de efeitos práticos ao direito pretendido pelo autor. Daí concluir-se que o regime de cumprimento não poderia ser o mesmo das sentenças

\footnotetext{
${ }^{243}$ Eduardo Talamini, em página de significativo alcance, examina a coordenação intrínseca entre a possibilidade de existência do direito e o periculum in mora, para concluir que a maior intensidade de um desses requisitos, importa mitigar a existência do outro ("quanto maior o periculum in mora, menor grau de probabilidade do direito invocado será necessária para a concessão da medida, e vice-versa"). Levando esse raciocínio ao nível da evidência, pode-se sustentar que ela dispensa o periculum in mora. TALAMINI, Eduardo. Tutela relativa aos deveres de fazer e de não fazer São Paulo: Ed. Revista dos Tribunais, 2001. p. 553.
} 
definitivas, uma vez que o padrão convencional retarda a concretização imediata dos efeitos supra-referidos ${ }^{244}$.

A efetivação tratada no $\S 3^{\circ}$ do art. 273 remete, indistintamente, ao regime da execução provisória do art. $475-0^{245}$ e ao previsto nos arts. $461, \S \S 4^{\circ}$ e $5^{\circ}$, e $461-\mathrm{A}$. Em teoria, o entendimento majoritário é o de que o primeiro regime foi destinado às antecipatórias pecuniárias e, o segundo, às demais. Mas o $\S 3^{\circ}$ fez a remissão com uma ressalva, qual seja a de que aqueles regimes se aplicam "no que couber". Assim, parecenos que o ponto de referência exegético há de ser o propósito maior do dispositivo, a sua razão de ser, que é propiciar a pronta realização de efeitos práticos.

Raciocinando nesses termos, pode-se vislumbrar uma atribuição executiva em caráter genérico, "aberto", que define ao juiz o objetivo e sinaliza os meios, a serem eleitos pelo próprio juiz de acordo com as necessidades do caso concreto. Em nosso entendimento, não há uma ordem do legislador para que os valores pecuniários objeto de decisão antecipatória pecuniária sejam perseguidos só pela via da execução provisória do art. 475-O. Não há por que a letra do $\S 3^{\circ}$ do art. 273 não foi redigida nesses termos e, também pela ressalva que o legislador cautelosamente inseriu ("no que couber"). Portanto, não está excluída a hipótese da execução mandamental, embora se tenha consciência de que este é um posicionamento minoritário, conquanto utilizado largamente na jurisprudência, em que o regime de multas (corolário da execução pecuniária mediante ordens) tem sido praticado com alguma freqüência ${ }^{246}$. Por outro lado, mesmo no regime do art. 475-O do CPC, existem obstáculos à realização efetiva dos efeitos práticos, como a exigência de caução (inc. III), ou o condicionamento à demonstração de estado de necessidade ou periculum in mora ( $\S 2^{\circ}$, inc. I e II), que podem esvaziar a efetividade, principalmente de provimento baseado na evidência, em que esses últimos requisitos podem não fazer sentido ${ }^{247}$.

\footnotetext{
${ }^{244}$ Esta é uma verdade praticamente restrita ao espaço das antecipatórias pecuniárias, pois no âmbito das obrigações de fazer e de entrega de coisa, o regime da antecipação trata de forma equivalente as antecipatórias e as definitivas.

${ }^{245} \mathrm{O}$ texto do $\S 3^{\circ}$ ainda refere o antigo art. 588, hoje substituído pelo 475-O.

${ }^{246}$ Flávio Luiz Yarshell posiciona-se contrário à idéia de execução mandamental, fundamentando, em parte, com a inviabilidade da prisão do devedor por dívidas. "Efetivação" da tutela antecipada: uma nova execução civil? In: FUX, Luiz; NERY JÚNIOR, Nelson; WAMBIER, Teresa Arruda Alvim (Coords.). Processo e Constituição: estudos em homenagem ao Professor José Carlos Barbosa Moreira, cit., p. 337. Concordamos com o argumento, razão pela qual situamos a mandamentalidade apenas no que se refere à pressão exercida mediante a ameaça da multa. No n. 11.3.5, infra, situam-se hipóteses em que faz sentido o requisito da caução nas antecipatórias baseadas no direito evidente.

${ }^{247}$ No n. 11.3.5, infra, situam-se hipóteses em que faz sentido o requisito da caução nas antecipatórias baseadas no direito evidente.
} 
Para encerrar, ainda há um breve comentário que se impõe, voltando um pouco atrás, em reforço da pretendida equiparação dos regimes de cumprimento das tutelas urgentes e daquelas baseadas no incontroverso, em que se inclui o direito evidente.

Observa-se que a diferença de tratamento neste ponto se origina em duas circunstâncias, quais sejam a vinculação do $\S 3^{\circ}$ ao julgamento antecipado e à identificação de um paradoxo, no qual o regime de cumprimento de uma sentença passaria a ser menos eficiente do que o de uma decisão interlocutória.

Quanto à primeira objeção, ela decorre da exegese convencional da palavra incontroverso, que é onde faz sentido ligar o $\S 3^{\circ}$ ao julgamento antecipado. A exegese alargou-se definitivamente, como demonstrado acima, pelo que a conexão perdeu seu ponto de referência. E sem o link exegético em tela de exame, a conclusão necessária é a de que o referido $\S 3^{\circ}$ não se trata de um simples remendo para superar a injustiça de quem cumulou pedidos e, por fazê-lo, acabou em desvantagem. Ainda que a mens legislatoris possa ter sido essa, o sentido da lei independe do querer subjetivo do legislador.

Nesse quadro de exegese ampliada do sentido de incontroverso, que conduz o preceito a desconectar-se progressivamente do instituto do julgamento antecipado, sobrevém o inc. LXXVIII do art. $5^{\circ}$ da CF. Sem embargo da mera reiteração que produziu acerca de valor já então presente no sistema, a nova disposição constitucional pelo menos há de ser tomada como um renovado chamar-a-atenção dos operadores para a necessidade capital de encurtar os caminhos do processo. Mas aqui se está operando em nível de abstração distanciado da realidade prática, que não oferece referenciais objetivos para delimitar a funcionalidade do $\S 3^{\circ}$ do art. 273. Como se a norma, desconectada do instituto do julgamento antecipado, ficasse suspensa em uma espécie de vácuo, apta a reger qualquer tipo de direito evidente, transferindo o problema da sua aplicação para um universo mais complexo ainda, que é o da identificação do evidente aceitável, em termos da teoria do processo, que não pode sobrevir do sentimento arbitrário e ocasional do juiz, da sua pura subjetividade, exigindo revelar-se com contornos e traços sustentáveis em patamares objetivos, compondo um conjunto coerente de idéias.

É então que o sistema de tratamento das demandas repetitivas, embora ainda incipiente no processo, completa o espaço carente de significação, possibilitando que o $\S 3^{\circ}$ do art. 273 seja operado na efetivação dessas demandas, naquele sentido original que conduziu o legislador a instituir o art. 273, qual seja o da produção imediata de efeitos práticos. E tudo implica a assimilação ao regime de cumprimento das tutelas de urgência. 
Por último, o paradoxo mediante o qual a interlocutória produz mais que a decisão definitiva deve ser examinado em seu verdadeiro sentido. Ou seja, paradoxal não é a eficácia da interlocutória, mas a ineficácia da decisão definitiva. $\mathrm{O}$ incômodo está no pouco que a sentença do direito evidente tende a produzir, em termos de lentidão, e não no quanto a interlocutória é eficiente para reduzir o tempo da sua realização prática. Afinal, o direito é evidente.

\subsubsection{A antecipação de efeitos de pedido único (inexistência de cumulação) e de parte de pedido}

Todas as vantagens que o art. $273, \S 3^{\circ}$, do CPC pode produzir estariam encerradas tão-só nas situações em que houvesse cumulação de pedidos. Fora disso, a mesma característica de direito incontroverso (evidência) perder-se-ia, tratada nos moldes convencionais da ordinariedade. Ora, a cumulação não agrega nada de substancial que justificasse, em si, uma transformação de eficácia dessa natureza. Daí concluir-se que é viável a antecipação da tutela do direito evidente quando ele for veiculado fora do regime da cumulação. A conclusão deriva não só da síntese lógica por último indicada. Soma-se todo o aporte de necessidades e idéias desenvolvido antes de chegar-se ao ponto específico do $\S 3^{\circ}$ ora examinado ${ }^{248}$

A esta altura, cabe observar que a evidência pode se limitar a parte do pedido e não ao todo. Assim, por exemplo, nos direitos homogêneos que se apresentem em demandas individuais repetitivas ao mesmo juízo, relativamente aos quais o núcleo de homogeneidade não for tão extenso, com a conseqüente presença de parcela relevante de heterogeneidade (n. 3.3, supra). Aí, o caráter evidente, como resultado da repetitividade, ficará provavelmente situado em partes da pretensão, impondo a antecipatória parcial na forma prevista no próprio $\S 3^{\circ}$ do art. 273 do CPC.

Outro aspecto que interage diretamente com este tema é o do nível de consenso jurisprudencial na definição da evidência. Há temas, cuja consolidação nos tribunais superiores é superlativa e outros que não atingem o mesmo nível de consenso. Não só por

\footnotetext{
${ }^{248}$ Teori Albino Zavaski, aproxima-se dessa conclusão ao referir que a "interpretação literal, que coloca a existência da cumulação de pedidos como pressuposto, em qualquer caso, reduziria sem razão lógica o âmbito das virtualidades do preceito normativo. Mas verdade, se é possível em face de dois preceitos cumulados adiantar a tutela de parte de um deles apenas, não há por que impedir que o mesmo ocorra quando o pedido for único.” ZAVASKI, Teori Albino. Antecipação de tutela, cit., p. 111.
} 
existirem posições divergentes, ainda que minoritárias, mas por eventualmente não terem chegado, ainda, àquelas Cortes. Por outro lado, há litigiosidades mais paroquiais, mas ainda assim repetitivas, que se movimentam apenas em primeiro e segundo grau, sem acesso aos Tribunais Superiores. Assim, a decisão judicial haverá de contemplar as peculiaridades contextuais em causa, eventualmente indeferindo pretensões, ou deferindoas parcialmente.

\subsubsection{Irreversibilidade}

O problema da irreversibilidade do provimento antecipado coloca-se com real intensidade no âmbito das tutelas urgentes, em que a decisão antecipatória pode conceberse com base na verossimilhança e, portanto, há efetivo risco de a sentença final revelar que não havia o direito que se adiantou em caráter irreversível. Quando, ao contrário, a antecipação é baseada em direito evidente, como aqui estudado, a possibilidade de prejuízo futuro ao réu fica muito mais rarefeita. Desse modo, se o risco maior foi assimilado pelo sistema em prol da efetividade, parece que o risco menor da antecipação do direito evidente dispensa preocupações adicionais.

Ao tratar da irreversibilidade aplicada ao tema da evidência, calha o exame comparativo com outra situação sedimentada no processo brasileiro, cuja síntese é a seguinte: a sentença de improcedência de embargos de devedor em execução de título extrajudicial suscita apelação recebida apenas no efeito devolutivo (art. 520, V, do CPC). Há situações em que o juiz pode atribuir efeito suspensivo (art. 739-A, do CPC), mas são excepcionais. Sendo aquela a regra, os embargos sobem ao Tribunal, e a execução prossegue na primeira instância, como definitiva, conforme art. 587 do CPC, que apenas incorporou o enunciado da Súmula 317 do STJ, em idêntico sentido.

O que pode ocorrer, então? Que os atos de expropriação se realizem, seja o dinheiro entregue ao devedor e, mais tarde, aconteça a reversão do julgamento, provendo-se os embargos para desconstituir a execução. Considerando que muitas vezes a improcedência em tela envolve teses jurídicas, o provimento dos embargos poderá ocorrer até mesmo no STJ, bem depor de finalizada a execução, portanto.

O que há, nesse caso, é a concessão de eficácia definitiva ao direito evidente. Somou-se ao título executivo extrajudicial, sinalizador muito forte da existência do direito, 
a sentença do juiz singular, reforçando ainda mais a convicção. Tudo indica, portanto, que o credor tem direito a receber. Pode ser que não tenha, mas esta é uma probabilidade realmente excepcional no contexto. Tão excepcional que não faria sentido aguardar todo o processamento das fases recursais, sob pena de moldar-se a regra pela exceção.

O irreversível, no caso, soluciona-se com base no princípio do solve et repete, cuja presença no âmbito do direito tributário foi anotada por Calamandrei no seu estudo sobre procedimentos monitórios $^{249}$, e que Ovídio Baptista da Silva indica como caminho para resolver as situações excepcionais do tipo verificável na execução objeto do exemplo acima formulado $^{250}$.

No âmbito das antecipatórias objeto deste estudo, não se descarta a possibilidade do manejo da caução do inc. II do art. 475-O do CPC como contrapartida da antecipação, caso o juiz entenda que o posicionamento adotado na decisão possa ser no futuro reformado, principalmente em vista de alterações de teses jurídicas no âmbito de Tribunais Superiores. Uma providência de cautela, tal como a lei entregou ao prudente arbítrio do juiz o atribuir, ou não, efeito suspensivo ao apelo dos embargos julgados improcedentes (art. 739-A do CPC). Mas tudo isso orientado pela consciência muito clara de que a exceção não se deve sobrepor à regra.

\subsubsection{A tutela de urgência em demandas repetitivas}

O sentido deste tópico é indicar que a tutela antecipatória aqui descrita, além de constituir vigoroso instrumento de efetividade em si mesma, opera no sentido de simplificar as necessidades daqueles que, tendo a evidência, mesmo assim se vêem obrigados a provar o periculum in mora para alcançar a realização prática de seus direitos. Isso expande muito a utilidade da fórmula, simplificando o acesso à justiça, sobretudo naqueles casos mais pungentes dos que necessitam buscar na via judicial meios de combater a doença, verificados no enorme contingente de demandas repetitivas contra o Poder Público para obtenção de remédios, tratamentos médicos e internações hospitalares.

\footnotetext{
${ }^{249}$ CALAMANDREI, Piero. El procedimiento monitorio, cit., p. 46.

${ }^{250}$ SILVA, Ovídio A. Baptista da. A “plenitude" de defesa no processo civil, cit., p. 109.
} 


\section{A tutela da evidência na obra de Luiz Fux - exame comparativo}

Logo após a promulgação da Lei 8.952, de dezembro de 1994, que inseriu o instituto da antecipação da tutela em caráter genérico no processo civil brasileiro, mediante a nova redação dos arts. 273 e 461 do CPC, sobreveio a obra de Luiz Fux intitulada Tutela de Segurança e Tutela da Evidência (Fundamentos da tutela antecipada).

No ponto específico da evidência, o autor parte da aferição de conflitos em que o direito do demandante se mostra macroscopicamente ao juiz desde o primeiro contato com a causa, do que resulta o convencimento integral prima facie: "A evidência propicia 'cognição exauriente e imediata', a mesma que se empreenderia ao final de um processo onde fossem necessárias etapas de dissipação da incerteza quanto ao direito alegado.” 251. Arrola hipóteses, tais como o direito provado por documento "que o consubstancie líquido e certo", ou o assentado em fatos incontroversos, ou notórios, ou revelado por meio de prova emprestada que se tenha obtido mediante o contraditório entre as partes em demanda anterior, etc ${ }^{252}$.

Para concentrar essas realidades em um conceito único, recorre à figura do direito líquido e certo ("mutatis mutandis poder-se-ia aplicar à evidência a doutrina da "liquidez e certeza" que informa o mandado de segurança e a execução" ${ }^{253}$ ), com a ressalva, contudo, de que a certeza judicial não é a certeza absoluta.

Identificado, assim, o contingente de situações objeto da tutela da evidência que propõe, verifica a inaptidão do processo convencional para produzir resultados compatíveis com esse nível de evidência, donde a injustiça em manter-se o autor submetido à demora desnecessária do procedimento. Denuncia, aí, o indevido processo legal e, portanto, imputa a essa demora desproporcional o veto da inconstitucionalidade. Em especial quando se vive, afirma, sob o signo da efetividade, em que a "aspiração social é a 'justiça urgente' em confronto com a 'justiça ordinária e ritual'.", 254.

Sustenta, então, o núcleo de sua tese, reclamando para o direito evidente o regime das antecipatórias, em uma espécie de equiparação da evidência à urgência. E propõe a

\footnotetext{
${ }^{251}$ FUX, Luiz. Tutela de segurança e tutela da evidência. São Paulo: Saraiva, 1996. p. 320.

${ }^{252}$ FUX, Luiz. Tutela de segurança e tutela da evidência, cit., p. 313.

${ }^{253}$ FUX, Luiz. Tutela de segurança e tutela da evidência, cit., p. 312.

${ }^{254}$ FUX, Luiz. Tutela de segurança e tutela da evidência, cit., p. 308.
} 
utilização dessa fórmula em caráter geral, para quaisquer tipos de demanda ${ }^{255}$. Por fim, coerente com os pressupostos de seu raciocínio, propugna a execução definitiva para as antecipatórias assim deferidas.

O próprio autor reconhece que essa linha argumentativa está presente, em seus elementos estruturais, na obra de Ovídio Baptista da Silva, inclusive a alusão ao direito líquido e certo ${ }^{256}$. Por fim, essa mesma linha de raciocínio pode-se também aferir na obra de Luiz Guilherme Marinoni ${ }^{257}$.

Merece destaque, nesse contexto de renomados juristas defendendo a tutela diferenciada para o direito evidente in genere, o fato de suas idéias não terem alcançado adesão na jurisprudência. Parece-nos que isso pode estar vinculado, entre outras causas, ao modo como a burocracia judiciária se expandiu, a partir da intensificação das demandas de massa, produzindo um autêntico efeito de contaminação (n. 1.3, supra) da "jurisdição convencional" pela "jurisdição massificada". Um quadro em que os processos são impulsionados de tal maneira que impede o acompanhamento crítico do juiz, indispensável para propiciar a consciência dele acerca da evidência prima facie. Interagindo com essa causa de natureza, digamos, operacional, provocada pelo congestionamento do Judiciário, destaca-se a característica "aberta" dos conceitos que envolvem a tutela da evidência como sustentada na obra de Luiz Fux, sem uma linha condutora que possa organizar em um sentido unívoco a dispersão inevitável que provoca na prática judiciária o imaginar-se a evidência como instituto aplicável a quaisquer tipos de demanda.

Por isso nos pareceu relevante iniciar a abordagem do tema justamente pelo modo como se dá o congestionamento judiciário, procurando funcionalizar nossa proposta para operar nesse contexto. E, por outro lado, fixando como linha condutora a idéia, já estabelecida no processo civil contemporâneo, das demandas repetitivas, o que abre possibilidades renovadas de interpretação e funcionamento da proposta, além de propiciar o manejo mais simplificado.

Naturalmente, isso só é possível, hoje, porque desde a publicação daquela obra inovadora houve três alterações legislativas, que autorizam a presente leitura do processo (arts. 273, $\S 6^{\circ}$, do CPC, 285-A do CPC, e inc. LXXVIII do art. $5^{\circ}$ da CF) sem contar as

\footnotetext{
${ }^{255}$ FUX, Luiz. Tutela de segurança e tutela da evidência, cit., p. 318.

${ }^{256}$ FUX, Luiz. Tutela de segurança e tutela da evidência, cit., p. 305-306.

${ }^{257}$ A idéia de que o direito evidente merece realização imediata está dispersa em várias passagens da obra do jurista, valendo citar, exemplificativamente MARINONI, Luiz Guilherme. Tutela antecipatória e julgamento antecipado: parte incontroversa da demanda, cit., p. 90-94.
} 
várias reformas que, como se disse no corpo do estudo, autorizam revelar uma tendência de tratamento diferenciado das demandas de repetitivas no processo civil atual.

\section{Considerações conclusivas}

A título de síntese de tudo que foi examinado ao longo do estudo, alinham-se as seguintes conclusões:

(1) A jurisdição evoluiu na modernidade, posicionando o juiz como agente político co-responsável pela criação do direito e, em certa medida, pela condução do Estado;

(2) Os novos espaços que a atividade jurisdicional ocupou, conforme síntese anterior, o incremento da litigiosidade na vida contemporânea e o fenômeno da massificação, estenderam quantitativa e qualitativamente as atribuições dos juízes e produziram o congestionamento do Judiciário.

(3) O congestionamento acentua a burocratização, que implica o risco das deformações próprias da burocracia, a comprometer a qualidade da jurisdição;

(4) Grande parte das ações de massa compõe-se de demandas individuais repetitivas, definíveis nos termos dos direitos individuais homogêneos, categoria própria da tutela coletiva. Nesse sentido, deveriam ser solucionadas em conjunto no interior de ações coletivas, cujo objetivo é justamente conter a atomização dos conflitos, resolvendo grandes contingentes litigiosos em uma única ação. Mas, examinadas mais de perto, as amplas soluções "moleculares" não têm como se verificar generalizadamente, de modo a estancar as ações repetitivas, por variados motivos, alguns de natureza transitória, dependentes de iniciativas do legislador, outros de caráter permanente, próprios da estrutura de certos direitos, ou de contingências culturais sedimentadas.

(5) A estrutura do processo civil convencional não foi concebida para distinguir e tratar diferentemente a litigiosidade de massa, que ingressa no Judiciário em milhares de ações repetitivas, em regra processadas pelo mesmo tipo de procedimento empregado às demandas convencionais. Só muito recentemente 
algumas reformas do CPC passaram a incluir dispositivos destinados ao manejo específico desse contingente litigioso.

(6) O conjunto de normas que têm por objetivo tratar a massificação no interior do Judiciário é composto, em sua maioria, por disposições aplicáveis aos recursos. Mas a mesma orientação já se faz sentir no primeiro grau, do que é exemplo o art. 285-A do CPC, permitindo ao juiz pronunciar a improcedência prima facie de ações repetitivas. Esse conjunto de normas autoriza afirmar uma tendência de tratamento diferenciado da litigiosidade massificada no processo civil.

(7) A jurisdição em demandas repetitivas obedece a padrões peculiares. Em linhas gerais, o debate amplo sobre o conflito de interesses acontece nas primeiras demandas, nas quais se formam as decisões, que depois serão replicadas nos demais casos que sobrevierem, do que são exemplos os arts. 543-A, § 5º e 285-A do CPC.

(8) Esse modelo define um regime de convencimento diferenciado daquele que se verifica nos litígios convencionais. As repetições não raro produzem no juiz a convicção sobre a procedência do pedido ao primeiro contato com a demanda, ou pelo menos muito antes do desfecho do processo. Trata-se de situação da mesma natureza daquela prevista pelo art. 285-A, apenas orientada em sentido contrário.

(9) A convicção prima facie do juiz pela procedência não constitui um mero sentimento incompatível com a convicção suficiente para decidir, que os postulados da segurança jurídica exigem na teoria do processo. Trata-se do resultado de um regime próprio de convicção, característico do universo da repetitividade, considerada não só em perspectiva jurídica, mas também como fenômeno social.

(10) Para o convencimento judicial no âmbito da repetitividade contribuem, com renovado vigor, dois institutos tradicionais do direito probatório, relativos aos fatos notórios e às máximas da experiência.

(11) Fixado que, no âmbito das ações repetitivas, o juiz pode se convencer de maneira suficiente para decidir a causa, seja prima facie, seja antes de encerrarse o procedimento, é imperativo que adiante os efeitos práticos do pedido do autor, sem exigir nada além da evidência direito e, pois, dispensando o periculum in mora. Essa antecipatória de tutela justifica-se não só pela 
efetividade reclamada na perspectiva individual, mas principalmente pela significação social e política que a pronta reação do Judiciário nesse tipo de ações massificadas proporciona.

(12) Sobretudo no âmbito das relações contratuais massificadas, em que os réus das ações repetitivas em geral são litigantes freqüentes (repeat players), a pronta realização prática dos direitos desfaz o atrativo que a demora do processo proporciona e, tendencialmente, promove a redução da litigiosidade.

(13) Considerando que o sistema processual não contempla em caráter genérico a antecipação de tutela da evidência, a via adequada para inserir a proposta objeto deste estudo é a do $\S 6^{\circ}$ do art. 273 do CPC, que trata das antecipatórias motivadas pelo direito incontroverso. Trata-se de alargar o conceito da lei, para nele inserir o direito evidente.

(14) Para a exegese do $\S 6^{\circ}$ do art. 273 do CPC, no contexto da repetitividade, não basta o exame dogmático do dispositivo no interior do CPC. Toda a relevância social e política por trás das ações massificadas, tudo que elas representam como fator paralisante do Judiciário e, por fim, todas as oportunidades que decorrem do modo como se verificam, são determinantes para o trabalho exegético. E, acima de tudo, é decisivo o comando do inc. LXXVIII, do art. $5^{\circ}$ da $\mathrm{CF}$, sobre a tempestividade da jurisdição que tenha em vista um direito evidente.

(15) Posicionadas as premissas da interpretação nos termos da quatro últimas proposições, conclui-se pela viabilidade da antecipação da tutela de direito evidente em ações repetitivas, inclusive inaudita altera parte, sem necessidade de acoplar à evidência o requisito da urgência. Por outro lado, considerando que a produção dos efeitos práticos em curto espaço de tempo constitui a essência da operacionalidade da proposta, o regime de efetivação é o mesmo daquele empregado para as medidas urgentes.

(16) A repetitividade aqui considerada, seguindo o padrão do art. 285-A do CPC, embora ligada fundamentalmente ao conceito de direitos individuais homogêneos, não se restringe àquele fenômeno, podendo ser manejada em casos mais próximos da jurisdição convencional, desde que preencham os pressupostos da norma acima mencionada. 


\section{REFERÊNCIAS BIBLIOGRÁFICAS}

ALEXY, Robert. El concepto y la validez del derecho. Tradução de Jorge M. Seña. Barcelona: Gedisa Editorial, 1994.

ALVES, José Carlos Moreira. Posse: evolução histórica. 2. ed. Rio de Janeiro: Forense, 1997. v. 1.

ANDOLINA, Italo. "Cognizione" ed "esecuzione forzata" nel Sistema della Tutela eiurisdizionale. Milano: Giuffrè, 1983.

ARAUJO FILHO, Luiz Paulo da Silva. Sobre a distinção entre interesses coletivos e interesses individuais homogêneos. In: FUX, Luiz; NERY JÚNIOR, Nelson; WAMBIER, Teresa Arruda Alvim (Coords.). Processo e Constituição: estudos em homenagem ao Professor José Carlos Barbosa Moreira. São Paulo: Ed. Revista dos Tribunais, 2006.

ARENHART, Sérgio Cruz. A antecipação de tutela e as alterações da lei 10.110/2002. In: MARINONI, Luiz Guilherme (Coord.). Estudos de direito processual civil: homenagem ao professor Egas Moniz de Aragão. São Paulo: Ed. Revista dos Tribunais, 2005.

ARMELIN, Donaldo. Tutela jurisdicional diferenciada. Revista de Processo, Sao Paulo, v. 17, n. 65, p .45-55, jan./mar. 1992.

ASSIS, Araken de. Cumprimento da sentença. Rio de Janeiro: Forense, 2006.

Duração razoável do processo e reformas da lei processual civil. In: FUX, Luiz; NERY JÚNIOR, Nelson; WAMBIER, Teresa Arruda Alvim (Coords.). Processo $e$ Constituição: estudos em homenagem ao Professor José Carlos Barbosa Moreira. São Paulo: Ed. Revista dos Tribunais, 2006.

BARROSO, Luís Roberto. Temas de direito constitucional. 2. ed. Rio de Janeiro: Renovar, 2006. t. 1, t. 3 .

BAUR, Fritz. Tutela jurídica mediante medidas cautelares. Porto Alegre: Sérgio Antônio Fabris, 1985. 
BEDAQUE, José Roberto dos Santos. Tutela cautelar e tutela antecipatória: tutelas sumárias e de urgência (tentativa de sistematização). 3. ed. rev. e ampl. São Paulo: Malheiros Ed., 2003.

Direito e processo: influência do direito material sobre o processo. 3. ed. São Paulo: Malheiros Ed., 2001.

BENJAMIN, Antônio Herman V. A insurreição da aldeia global contra o processo civil clássico: apontamentos sobre a opressão e a libertação judiciais do meio ambiente e do consumidor, In: MILARÉ, Édis (Coord.). A ação civil pública: lei 7.347/85: reminiscências e reflexões após dez anos de aplicação. São Paulo: Ed. Revista dos Tribunais, 1995.

BOBBIO, Norberto. A era dos direitos. Rio de Janeiro: Campus/Elsevier, 2004.

BONAVIDES, Paulo. Curso de direito constitucional. 12. ed. São Paulo: Malheiros Ed., 2001.

BUONCRISTIANI, Dino. Sistema dei "référé": tutela cautelare dal pregiudizo e tutela urgente senza pre-giudizio. Rivista Trimestrale di Diritto e Procedura Civile, Milano, ano 60, n. 2, jun. 2006.

CALAMANDREI, Piero. El procedimiento monitorio. Buenos Aires: Bibliográfica, 1946.

CANÍBAL, Carlos Roberto Lofego. Estudos de direito constitucional tributário e processo civil. Porto Alegre: Pallotti, 2006.

CANOtILHO, J. J. Gomes. Direito constitucional e teoria da Constituição. Coimbra: Almedina, 1998.

CAPPELLETTI, Mauro. Formazioni sociali e interessi di grupo davanti allá giustizia civile. Rivista di Diritto Processuale, Padova, n. 30, p. 361-402, 1975.

Juizes legisladores? Porto Alegre: Sérgio Antônio Fabris, 1993.

.. Problemas de reforma do processo civil nas sociedades contemporâneas. Revista de Processo, Sao Paulo, v. 17, n. 65, p. 127-143, jan./mar. 1992.

; GARTH, Bryant. Acesso à justiça. Porto Alegre: Sérgio Antônio Fabris, 1988. 
CARNEIRO, Athos Gusmão. Cumprimento da sentença civil. Rio de Janeiro: Forense, 2007.

CARNELUTTI, Francesco. Diritto e processo. Napoli: Morano, 1958.

La prova civile. 2. ed. Roma: Dell'ateneo, 1947.

Instituciones del proceso civil. Buenos Aires: EJEA, 1960. v. 3.

COMOGLIO, Luigi Paolo. Etica e tecnica del "giusto processo". Torino: G. Giappichelli, 2000. (Biblioteca di Diritto Processuale Civile, n. 28).

CRUZ E TUCCI, José Rogério. Garantia da prestação jurisdicional sem dilações indevidas, como corolário do devido processo legal. Revista de Processo, São Paulo, v. 17, n. 66, p. 72-78, abr./jun. 1992.

CRUZ E TUCCI, José Rogério. Lineamentos da nova reforma do CPC. 2. ed. São Paulo: Ed. Revista dos Tribunais, 2002.

. Tempo e processo. São Paulo: Ed. Revista dos Tribunais, 1997.

_. Precedente judicial como fonte do direito. São Paulo: Ed. Revista dos Tribunais, 2004.

DEL CLARO, Roberto. Devido processo substancial? In: MARINONI, Luiz Guilherme (Org.). Estudos de direito processual civil: homenagem ao Prof. Egas Dirceu Moniz de Aragão. São Paulo: Ed. Revista dos Tribunais, 2005.

DENTI, Vittorio. Crisi della giustizia e crisi della societtà. Rivista di Diritto Processuale, Padova, n. 4, p. 585-597, 1983.

DIDIER JUNIOR, Fredie. Inovações na antecipação dos efeitos da tutela e a resolução parcial de mérito. Revista de Direito Processual Civil, n. 26, 2002.

DINAMARCO, Cândido Rangel. Fundamentos do processo civil moderno. São Paulo: Malheiros Ed., 2001. v. 2.

. Instituições de direito processual civil. 5. ed. São Paulo: Malheiros Ed., 2005. v. 1.

. Instituições de direito processual civil. São Paulo, Malheiros Ed., v. 2.

. A instrumentalidade do processo. 11. ed. São Paulo: Malheiros Ed., 2003. 
DWORKIN, Ronald. Levando os direitos a sério. São Paulo: Martins Fontes, 2002.

FABRÍCIO, Adroaldo Furtado. Comentários ao Código de Processo Civil. 8. ed. Rio de Janeiro: Forense, 2001. v. 8, t. 3.

Comentários ao Código de Processo Civil. 8. ed. Rio de Janeiro: Forense, 2001. v. 8, t. 3 .

. Fatos notórios e máximas da experiência. In: MORAES, Maurício Zanóide de (Org). Estudos em Homenagem à Professora Ada Pellegrini Grinover. São Paulo: DPJ Ed. 2005.

. As novas necessidades do processo civil e os poderes do juiz. Revista de Direito do Consumidor, São Paulo, n. 7, p. 30-36, jul./set. 1993.

FAIREN GUILLÉN, Víctor. El juicio ordinário y los plenarios rápidos. Barcelona: Bosch, 1953.

FARIA, Eduardo. A definição do interesse público. In: SALLES, Carlos Alberto (Org.). Processo civil e interesse público. São Paulo: Associação Paulista do Ministério Público; Ed. Revista dos Tribunais, 2003.

FAZZALARI, Elio, Il giusto processo e i "procedimenti speciali" civili. Rivista Trimestrale di Diritto e Procedura Civile, Milano, ano 57, p. 1-51, mar. 2003.

Instituições de direito processual. Campinas: Bookseller, 2006.

FERREIRA, Aurélio Buarque de Holanda. Novo Dicionário Século XXI: o dicionário da língua portuguesa. 3. ed. Rio de Janeiro: Nova Fronteira, 1999.

FIGUEIRA JUNIOR, Joel Dias. Liminares nas ações possessórias. 2. ed. São Paulo: Ed. Revista dos Tribunais, 1999.

FISS, Owen. Um novo processo civil: estudos norte-americanos sobre jurisdição. São Paulo: Ed. Revista dos Tribunais, 2004.

FRANCO, Alberto Silva. O perfil do juiz na sociedade em processo de globalização. In: MORAES, Maurício Zanóide de (Org.). Estudos em homenagem à Professora Ada Pellegrini Grinover. São Paulo: DPJ Ed., 2005. 
FURNO, Carlos. Teoria de la prueba legal. Madrid: Revista de Derecho Privado, 1954.

FUX, Luiz. Tutela de segurança e tutela da evidência. São Paulo: Saraiva, 1996.

GIDI, Antonio. Coisa julgada e litispendência nas ações coletivas. São Paulo: Saraiva, 1995.

GRECO FILHO, Vicente. Direito processual civil brasileiro. 19. ed. São Paulo: Saraiva, 2008. v. 2.

GRINOVER, Ada Pellegrini. A antecipação de tutela e sua estabilização. In: MARINONI, Luiz Guilherme (Org.). Estudos de direito processual civil: homenagem ao Prof. Egas Dirceu Moniz de Aragão. São Paulo: Ed. Revista dos Tribunais, 2005.

Da class action for damages à ação de classe brasileira: os requisitos de admissibilidade. In: O processo: estudos e pareceres. São Paulo: Perfil, 2005.

et al. Código Brasileiro de Defesa do Consumidor comentado pelos autores do anteprojeto. Rio de Janeiro: Forense Universitária, 1991.

GUARNIERI, Carlo; PEDERZOLI, Patrizia. La democrazia giudiziaria. Bologna: Soc. Editrice il Mulino, 1997.

HOJI, Masakazu. Administração financeira: uma abordagem prática. 5. ed. São Paulo: Atlas, 2004.

HOUAISS, Antônio; VILlAR, Mauro de Salles. Dicionário Houaiss da língua portuguesa. Rio de Janeiro: Objetiva, 2001.

KUHN, Thomas. Estrutura das revoluções científicas. 3. ed. São Paulo: Perspectiva, 1992.

LACERDA, Galeno de. Comentários ao Código de Processo Civil. 6. ed. Rio de Janeiro: Forense, 2001. v. 8, t. 1.

Processo e cultura. Revista de Direito Processual Civil, São Paulo, ano 3, p. 74$86,1962$.

LAFER, Celso. A reconstrução dos direitos humanos: um diálogo com o pensamento de Hannah Arendt. 6. reimpr. São Paulo: Companhia das Letras, 2006. 
LARENZ, Karl. Metodologia da ciência do direito. 3. ed. Lisboa: Fundação Calouste Gulbenkian, 1997.

LOPES, Bruno Vasconcelos Carrilho. Tutela antecipada sancionatória. São Paulo: Malheiros Ed., 2006.

LUCON, Paulo Henrique dos Santos; SILVA, Érica Barbosa da. Análise crítica da liquidação e execução na tutela coletiva. In: LUCON, Paulo Henrique dos Santos (Coord.). Tutela coletiva: 20 anos da Lei da Ação Civil Pública e do Fundo de Defesa de Direitos Difusos: 15 anos do Código de Defesa do Consumidor. São Paulo: Atlas, 2006.

MANCUSO, Rodolfo de Camargo. Ação civil pública em defesa do meio ambiente, do patrimônio cultural e dos consumidores. 4. ed. São Paulo: Ed. Revista dos Tribunais, 1996. Interesses difusos: conceito e legitimação para agir. 6. ed. São Paulo: Ed. Revista dos Tribunais, 2004.

Jurisdição coletiva e coisa julgada: teoria geral das ações coletivas. 2. ed. São Paulo: Ed. Revista dos Tribunais, 2007.

MARINONI, Luiz Guilherme. Antecipação da tutela. 9. ed. São Paulo: Ed. Revista dos Tribunais, 2006.

Tutela antecipatória e julgamento antecipado. Parte incontroversa da demanda. 5. ed. São Paulo: Ed. Revista dos Tribunais, 2003.

; ARENHART, Sérgio Cruz. Processo de conhecimento. 7. ed. rev. e atual. São Paulo: Ed. Revista dos Tribunais, 2008. v. 2.

MELERO, Valetin Silva. La Prueba Procesal. Madrid: Ed. de Revista de Derecho Privado, 1963.

MELO, Celso Antônio Bandeira de. Eficácia das normas constitucionais sobre justiça social. Revista de Direito Público, São Paulo, n. 57/58, p. 233-256, 1981.

MENDES, Aluísio Gonçalves de Castro Mendes. Anteprojeto de Código Brasileiro de Processos Coletivos. In: GRINOVER, Ada Pellegrini; CASTRO, Aluisio Gonçalves; WATANABE, Kazuo (Orgs.). Direito processual coletivo e o Anteprojeto do Código Brasileiro de Processos Coletivos, São Paulo: Ed. Revista dos Tribunais, 2007. 
MICHELI, Gian Antonio. La carga de la prueba. Tradução Santiago Santis Meleno. Buenos Aires: EJEA, 1961.

MIRANDA, Francisco Cavalcanti Pontes de. Comentários à Constituição de 1946. 3. ed. Rio de Janeiro: Borsoi, 1960. t. 1.

MOREIRA, Carlos Roberto Barbosa. Notas sobre a inversão do ônus da prova em benefício do consumidor. Revista de Direito do Consumidor, São Paulo, n. 22, p. 135-149, abr./jun. 1997.

MOREIRA, José Carlos Barbosa. Comentários ao Código de Processo Civil. 14. ed. rev. e atual. Rio de Janeiro, Forense, 2008. v. 5.

. Notas sobre o problema da "efetividade" do processo. In: Temas de direito processual civil: $3^{\mathrm{a}}$ série. São Paulo: Saraiva, 1984.

Prueba y motivación de la sentencia In: Temas de direito processual: oitava série. São Paulo: Saraiva, 2004.

. Tendências contemporâneas do direito processual civil. Revista da Ajuris, Porto Alegre, ano 12, n. 34, jul. 1985.

. Tutela jurisdicional dos interesses coletivos ou difusos. In: . Temas de direito processual, $3^{\text {a }}$ série. São Paulo: Saraiva, 1984.

. Regras da experiência e conceitos juridicamente indeterminados. Revista Forense, Rio de Janeiro, ano, v. 261, p. 13-19, jan/mar 1978.

(Coord.). Estudos de direito processual em memória de Luiz Machado Guimarães. Rio de Janeiro: Forense, 1999.

NERY JUNIOR, Nelson; NERY, Rosa Maria de Andrade. Código de Processo Civil Comentado e Legislação Extravagante. 10. ed. São Paulo: Ed. Revista dos Tribunais, 2008.

NETO, Abílio. Código de Processo Civil Anotado. 14ª ed. Lisboa: Ediforum, 1997.

OLIVEIRA, Carlos Alberto Álvaro de. Efetividade e processo de conhecimento. Revista da Ajuris, Porto Alegre, v. 26, n. 75, p. 120-135, set. 1999. 
OLIVEIRA, Carlos Alberto Álvaro de. Formas de tutela jurisdicional no chamado processo de conhecimento. Revista da Ajuris, Porto Alegre, v. 32, n. 100, p. 59-72, dez. 2005.

Do formalismo no processo civil. 2. ed. São Paulo: Saraiva, 2003.

PASSOS, José Joaquim Calmon de. Comentários ao Código de Processo Civil. 9. ed. Rio de Janeiro: Forense, 2005. v. 3.

PERROT, Roger. Il nuovo e futuro Codice di Procedura Civile Francese. Rivista di Diritto Processuale, Padova, v. 30, n. 2, p. 228-264, genn./dic. 1975.

PINTO, Fernanda Guedes. Ações repetitivas e o novel art. 285-A do CPC. Revista de Processo, São Paulo, v. 32, n. 150, p. 121-157, ago. 2007.

PISANI, Andrea Proto. Sulla tutela giurisdizionale differenziata. Rivista di Diritto Processuale, Milano, 1979.

PIZZOL, Patrícia Miranda. A tutela antecipada nas ações coletivas como instrumento de acesso à justiça. In: FUX, Luiz; NERY JÚNIOR, Nelson; WAMBIER, Teresa Arruda Alvim (Coords.). Processo e Constituição: estudos em homenagem ao Professor José Carlos Barbosa Moreira. São Paulo: Ed. Revista dos Tribunais, 2006.

PORTO, Sérgio Gilberto. A Crise de Eficiência do Processo - A Necessária Adequação Processual à Natureza do Direito Posto em Causa, como Pressuposto de Efetividade. In: FUX, Luiz et al. Processo e Constituição. Estudos em Homenagem ao Professor José Carlos Barbosa Moreira. São Paulo: RT, 2006.

RAWLS, John. Uma teoria da justiça. São Paulo: Martins Fontes, 1997.

ROSEMBERG, Leo. La carga de la prueba. Buenos Aires: Ediciones Jurídicas EuropaAmerica, 1956.

ROSITO, Francisco. Direito probatório: as máximas de experiência em juízo. Porto Alegre: Livr. do Advogado, 2007.

SALLES, Carlos Alberto de. Execução específica e ação civil pública. In: MILARÉ, Edis (Coord.). A ação civil pública após 20 anos: efetividade e desafios. São Paulo: Ed. Revista dos Tribunais, 2005. 
SALlES, Carlos Alberto de (Org.). Processo civil e interesse público. São Paulo: Associação Paulista do Ministério Público; Ed. Revista dos Tribunais, 2003.

SANDRONI, Paulo. Dicionário de economia do século XXI. Rio de Janeiro: Record, 2005.

SANTOS, Boaventura de Sousa et al. Os tribunais nas sociedades contemporâneas: o caso português. Porto: Afrontamento, 1996.

SANTOS, Moacyr Amaral. Comentários ao Código de Processo Civil. 4. ed. Rio de Janeiro: Forense, 1986. v. 4.

Prova judiciária no cível e comercial. 2. ed. atual. São Paulo: Max Limonad, 1955. v. 5.

SARLET, Ingo Wolfgang. A eficácia dos direitos fundamentais. Porto Alegre: Livraria do Advogado, 2006.

SCHMIDT, Ricardo Pippi. Administração judiciária e os juizados especiais cíveis: o caso do Rio Grande do Sul. Porto Alegre: Tribunal de Justiça do Estado do Rio Grande do Sul, 2008 .

SCIALOJA, Vittorio. Procedimiento civil romano. Buenos Aires: EJEA, 1954.

SIFUENTES, Mônica. Súmula vinculante: um estudo sobre o poder normativo dos tribunais. São Paulo: Saraiva, 2005.

SILVA, João Carlos Pestana de Aguiar. Apontamentos sobre a posse e os procedimentos possessórios. Revista de Processo, São Paulo, v. 40, p. 13-39, 1985.

SILVA, José Afonso da. Aplicabilidade das normas constitucionais. 2. ed. São Paulo: Ed. Revista dos Tribunais, 1982.

. Curso de direito constitucional positivo. 31. ed. São Paulo: Malheiros Ed., 2008.

SILVA, Ovídio A. Baptista da. Curso de Processo Civil. 3. ed. São Paulo: Ed. Revista dos Tribunais, 2000. v. 3.

A "plenitude" de defesa no processo civil. In: Da sentença liminar à nulidade da sentença. Rio de Janeiro: Forense, 2002. 
SILVA, Ovídio A. Baptista da. Sobre o valor da prova emprestada. 5. ed. São Paulo: Ed. Revista dos Tribunais, 2000.

STEIN, Friedrich. El conocimiento privado del juez. Tradução de Andrés de La Oliva Santos. Bogotá: Editorial Temis, 1988.

STUMPF, Juliano da Costa. Poder Judiciário: morosidade e inovação. Porto Alegre: Tribunal de Justiça do Estado do Rio Grande do Sul, 2009.

SUPERIOR TRIBUNAL DE JUSTIÇA. Disponível em: <www.stj.gov.br>. Acesso em: 29 out. 2008.

TALAMINI, Eduardo. Tutela relativa aos deveres de fazer e de não fazer São Paulo: Ed. Revista dos Tribunais, 2001.

TARZIA, Giuseppe. L'art. 111, cost. e le garanzie europee del proceso civile. Revista de Processo, São Paulo, ano 26, n. 103, jul./set. 2001.

O novo processo civil de cognição na Itália. Revista da Ajuris, Porto Alegre, v. 22, n. 65, p. 73-91, nov. 1995.

THEODORO JÚNIOR, Humberto. Tutela antecipada - Evolução - Visão comparatista Direito brasileiro e direito europeu. In: CARNEIRO, Athos Gusmão; CALMON, Petrônio (Coord.). Bases científicas para um renovado direito processual. Brasília: Instituto Brasileiro de Direito Processual, 2008. v. 1, p. 423-442.

TOMMASEO, Ferruccio. Appunti di diritto processuale civile: nozione introduttive. 4. ed. Torino: G. Giappichelli, 2000.

TRIBUNAL DE JUSTIÇA DO ESTADO DO RIO GRANDE DO SUL. Disponível em: <www.tj.rs.gov.br>. Acesso em: 14 jan. 2009.

TRIBUNAL DE JUSTIÇA DO RIO DE JANEIRO. Disponível em: <http://www.tj.rj.gov.br/corregedoria/serviços>. Acesso em: 29 jan. 2008.

TROCKER, Nicolò. Processo civile e costituzione: problemi di diritto tedesco e italiano. Milano: A. Giuffrè, 1974.

O VALOR, São Paulo, 28, 29 e 30 nov. 2008, p. E-1-E-2. 
WATANABE, Kazuo. A tutela antecipatória e tutela específica das obrigações de fazer e não fazer. Revista da Ajuris, Porto Alegre, v. 23, n. 66, p. 160-190, mar. 1996.

et al. Código Brasileiro de Defesa do Consumidor comentado pelos autores do anteprojeto. Rio de Janeiro: Forense Universitária, 1991.

Da cognição no processo civil. 2. ed. atual. Campinas: Bookseller, 2000.

WEBER, Max. Ensaios de sociologia. 5. ed. Rio de Janeiro: LTC, 2002.

WEINGARTNER NETO, Jayme. Existe a única resposta jurídica correta? Direito $e$ Democracia, Porto Alegre, v. 5, n. 1, p. 85-120, 2004.

YARSHELL, Flávio Luiz. "Efetivação" da tutela antecipada: uma nova execução civil? In: FUX, Luiz; NERY JUNIOR, Nelson; WAMBIER, Teresa Arruda Alvim (Coords.). Processo e Constituição: estudos em homenagem ao Professor José Carlos Barbosa Moreira. São Paulo: Ed. Revista dos Tribunais, 2006.

Observações a propósito da liquidação na tutela de direitos individuais homogêneos. In: WAMBIER, Teresa Arruda Alvim (Coord.). Atualidades sobre liquidação de sentença. São Paulo: Ed. Revista dos Tribunais, 1997.

A reforma do judiciário e a promessa de duração razoável do processo. Revista do Advogado, São Paulo, v. 24. n. 75, p. 28-33, abr. 2004.

A reforma do judiciário e a vigência de medidas liminares. Revista do Advogado, São Paulo, n. 56, p. 44-49, set. 1999.

. Tutela mandamental nas obrigações de pagamento de quantia. Revista da Procuradoria Geral do Estado de São Paulo, São Paulo, jan./dez. 2003.

; MATEUCCI, Carlos Roberto F.; PINTO, Luís Otávio Camargo. Eficácia probatória do documento eletrônico. Repertório IOB de Jurisprudência, n. 21, p. 489-493, 1999.

ZAVASKI, Teori Albino. Antecipação de tutela. 5. ed. São Paulo: Saraiva, 2007.

Antecipação de tutela e colisão de direitos fundamentais. Revista da Ajuris, Porto Alegre, n. 64, p. 395-417, 1995.

Processo coletivo: tutela de direitos coletivos e tutela coletiva de direitos. 2. ed. rev. e atual. São Paulo: Ed. Revista dos Tribunais, 2007. 